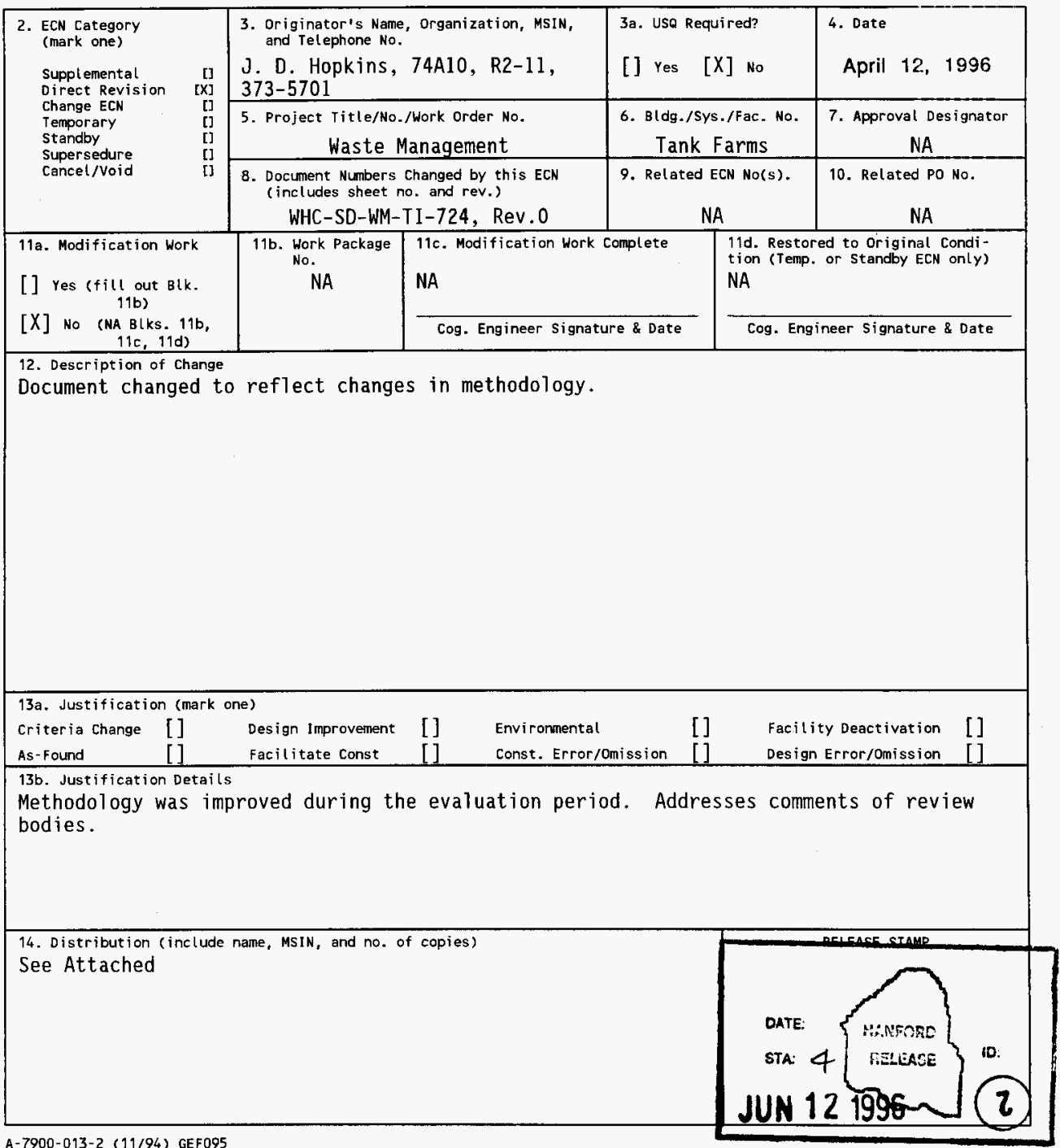




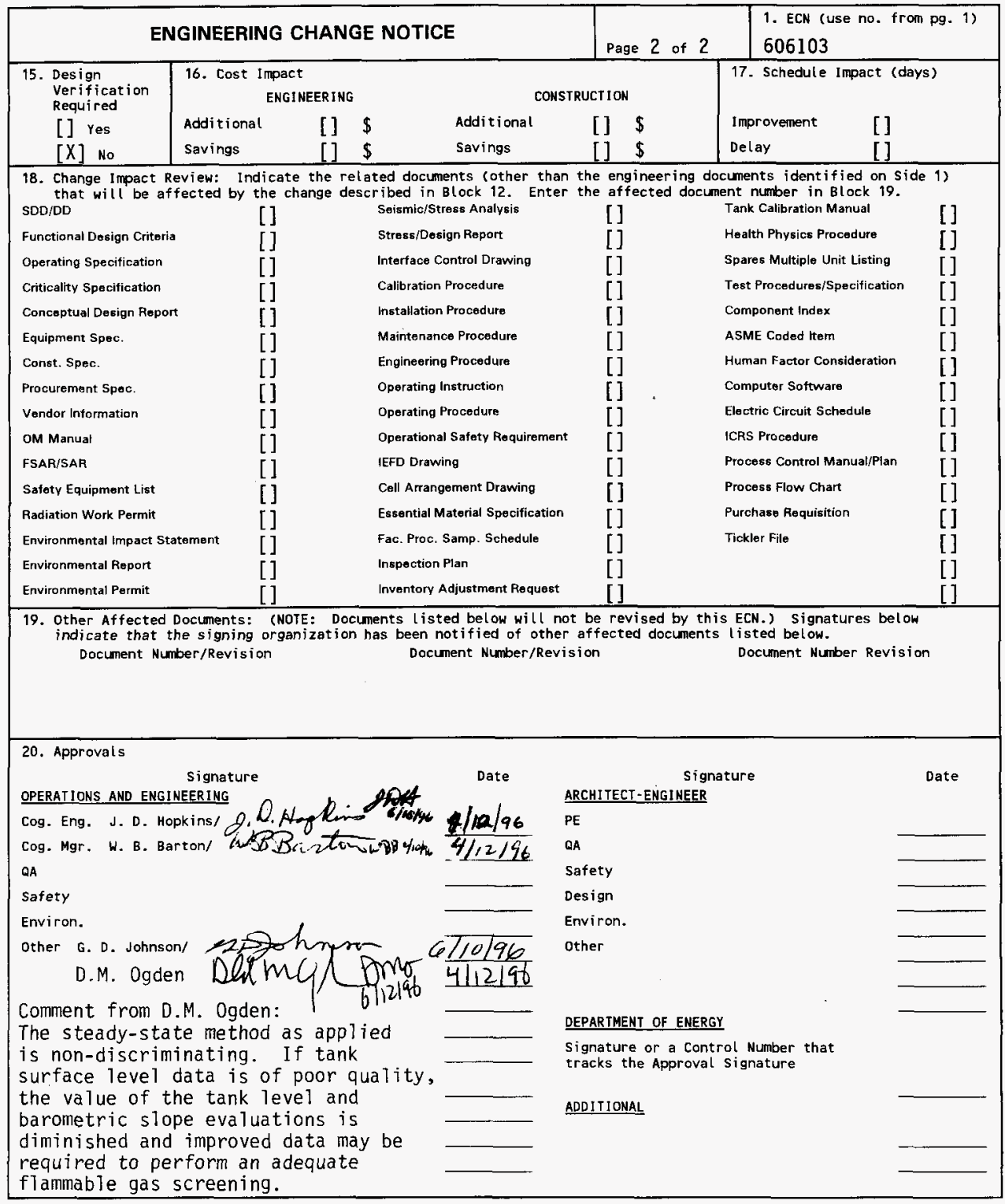




\title{
Methodology For Flammable Gas Evaluations
}

\author{
J. D. Hopkins
}

Westinghouse Hanford Company, Richland, WA 99352

U.S. Department of Energy Contract DE-AC06-87RL10930

ECW 406103

EDT/ECN: $610259-$

Org Code: 74A10

B\&R Code: EW3120072

UC: 2030

Charge Code: N2156

Total Pages: 199

Key Words: Trapped Gas; Flammable Gas; Hydrogen; Episodic Gas Release; Barometric Slope; Surface Level Rise; Quick Screen; Flammable Gas Criteria; Steady State Concentration; Monte Carlo Analysis; Plume Burn; Over Pressurization; Waste Evaporation; Raleigh-Taylor.

Abstract: There are 177 radioactive waste storage tanks at the Hanford Site. The waste generates flammable gases. The waste releases gas continuously, but in some tanks the waste has shown a tendency to trap these flammable gases. When enough gas is trapped in a tank's waste matrix, it may be released in a way that renders part or all of the tank atmosphere flammable for a period of time. Tanks must be evaluated against previously defined criteria to determine whether they can present a flammable gas hazard. This document presents the methodology for evaluating tanks in two areas of concern in the tank headspace: steady-state flammable-gas concentration resulting from continuous release, and concentration resulting from an episodic gas release.

EXCEL is a Registered Trademark of the Microsoft Corporation

TRADEMARK DISCLAIMER. Reference herein to any specific commercial product, process, or service by trade name, trademark, manufacturer, or otherwise, does not necessarily constitute or imply its endorsement, recommendation, or favoring by the United States Government or any agency thereof or its contractors or subcontractors.

Printed in the United States of America. To obtain copies of this document, contact: WHC/BCS Document Control Services, P.O. Box 1970, Mailstop H6-08, Richland WA 99352, Phone (509) 372-2420; Fax (509) 376-4989.
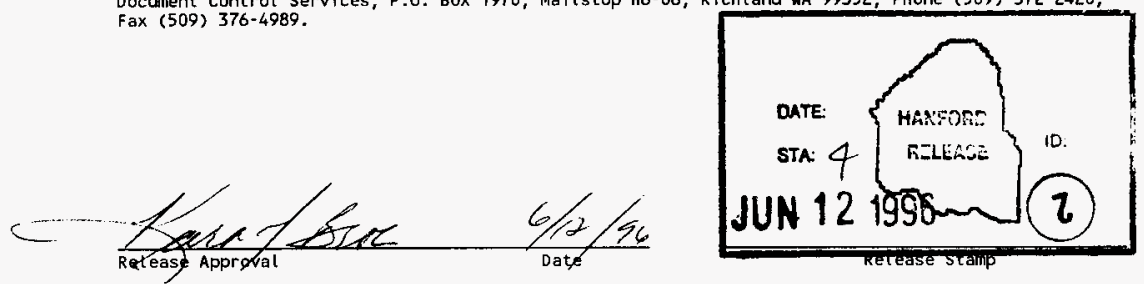

Approved for Public Release 


\section{RECORD OF REVISION}

(2) Title

Methodology For Flammable Gas Evaluations

CHANGE CONTROL RECORD

(3) Revision (4) Description of Change - Replace, Add, and Delete Pages

(7) Methodology For Flammable Gas Evaluations

1 RS Incorporated changes to methodology ECN-606103
Authorized for Release

(5) Cog. Engr. (6) Cog. Mgr. Date

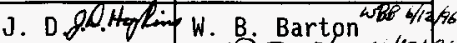
Hopkins 
WHC-SD-WM-TI-724, Rev. 1

\title{
METHODOLOGY FOR
}

\section{FLAMMABLE GAS}

EVALUATIONS

\author{
J. D. Hopkins
}

Westinghouse Hanford Company

June 10, 1996 
WHC-SD-WM-TI-724, Rev. 1

This page intentionally left blank. 


\section{CONTENTS}

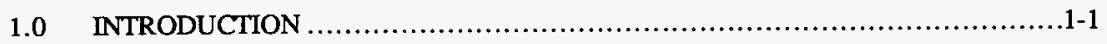

2.0 FLAMMABLE GAS WATCH LIST CRITERIA AND LOGIC .......................2-1

3.0 TANK DATA REQUIREMENTS ..............................................................

4.0 EVALUATION OF STEADY-STATE CONCENTRATION ...........................4-1

5.0 EVALUATION OF EGR: LOGIC ...............................................

6.0 EVALUATION OF EGR: QUICK SCREEN VS. TANK 101-SY ..................6-1

7.0 EVALUATION OF EGR BASED ON SURFACE LEVEL RISE .....................7-1

8.0 ESTIMATE OF EGR BASED ON BAROMETRIC SLOPE $\ldots \ldots \ldots \ldots \ldots \ldots \ldots \ldots \ldots . . . . .1$

9.0 OTHER POTENTIAL FLAMMABILITY HAZARDS ...............................9-1

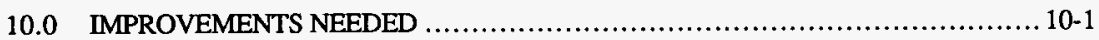

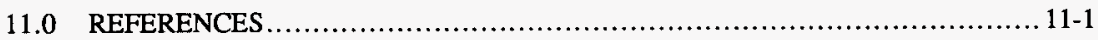

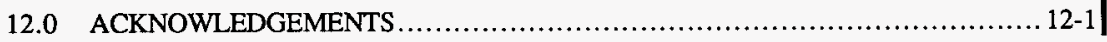

\section{ATTACHMENTS}

A. TANK DATA REQUIREMENTS ..................................... A-1

B. LOGIC AND TECHNICAL DETAILS .................................... B-1

C. SPREADSHEET AND INSTRUCTIONS ...........................................

D. UNCERTAINTIES INVOLVING SURFACE LEVEL GAUGES .............. D-1

E. TECHNICAL BASIS FOR CENTER OF TRAPPED GAS .................. E-1

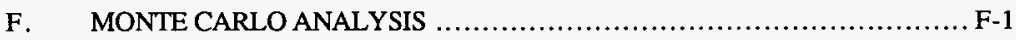

G. DISTRIBUTION OF BAROMETRIC SLOPES ........................G-1

H. VOID FRACTION RESULTS FOR TANK 241-SY-103 …................H-1

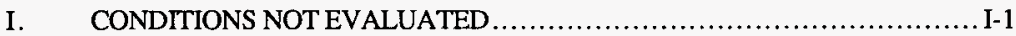

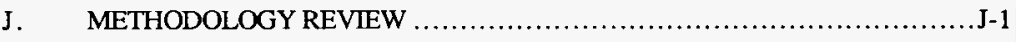

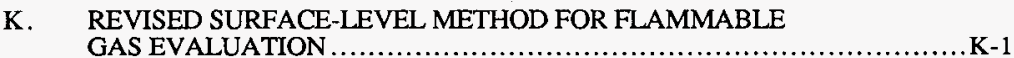

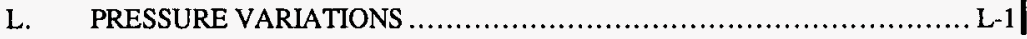




\section{FIGURES}

5-1 Fumaroles in Tank 241-T-107. ............................................. $5-1$

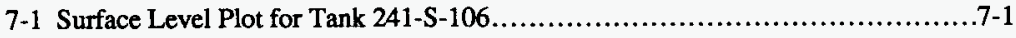

7-2 Interstitial Liquid Level Plot for Tank 241-TX-112.............................. 7-1

7-3 Monte Carlo Distribution for Volume of $\mathrm{H}_{2}$ Emitted............................. 7-5

7-4 Sensitivity Chart: Contribution to Variance by Individual Parameters................7-5

8-1 Increase in Barometric Pressure Compresses Gas.................................8-1

8-2 Surface Level and Inverse Pressure for Tank 241-S-106...............................8-2

\section{TABLES}

8-1 Effect of Surface Tension on Gas Volume and \% LFL .......................... 8-1 


\section{LIST OF TERMS}

DOE U.S. Department of Energy

DSI

Don't Say It-Write It

DST

double-shell tank

EGR

episodic gas release

ENRAF

FGWL

FIC

HEPA

HMS

ILL

LFL

LLC

LLH

MT

PC-SACS

PNNL

SD

SL

SLC

SLH

SST

ENRAF-NONIUS B.V. Corporation (surface-level measurement device)

Flammable Gas Watch List

Food Instrument Corporation (surface-level measurement device)

high-efficiency particulate air

Hanford Meteorological Station

interstitial liquid level

lower flammability limit

liquid level, current

liquid level, historical

manual tape (level measurement device)

Personal Computer Surveillance Analysis Computer System

Pacific Northwest National Laboratory

standard deviation

surface level

solids level, current

solids level, historical

single-shell tank

TMACS Tank Monitoring and Control System

TOC

VFI

VDTT

w.g. total organic carbon void fraction instrument

Velocity-Density-Temperature Tree

water gauge 
WHC-SD-WM-TI-724, Rev. 1

This page intentionally left blank. 


\subsection{INTRODUCTION}

\subsection{BACKGROUND}

There are 177 radioactive waste storage tanks containing over 55 million gallons of radioactive wastes at the Hanford Site. The wastes generate flammable gases, and some of the wastes have shown a tendency to trap these flammable gases. When enough gas is trapped in a tank's waste matrix, it may be released in a way that renders part or all of the tank atmosphere flammable for a period of time.

To ensure safety of workers, the public and the environment, a graded set of controls must be applied to the tanks. These controls allow the risks posed by the trapped gases to be managed during continued progress toward permanent disposal of the waste.

The controls are implemented through a series of documents. These documents contain the flammable gas criteria for applying the controls (Hopkins 1994), methodology for evaluating the tanks against the criteria (presented in this document), the evaluation results (Hodgson et al. 1996) and operating specification documents (WHC 1995a, 1995b, 1995c and 1995d).

\subsection{PURPOSE}

Since Revision 0 of this document was published in December 1995, the methodology used to evaluate the Hanford Site waste storage tanks against the flammable gas criteria (Hopkins 1994) has undergone continuous improvement. This revision describes the methodology in use on March 31, 1996, when the evaluation results (Hodgson et al. 1996) were published. The methodology includes excess conservatism in some areas, for example, the passive tank ventilation rate used to calculate steady-state concentration, the estimated fraction of trapped gas released, the estimated percentage of $\mathrm{H}_{2}$ in released gas, estimated evaporation in the surface-level-rise method, and the use of the 75th-percentile barometric slope. As understanding of these and other areas improves, it is expected that the methodology will be improved and new methods developed.

\subsection{ORGANIZATION OF THIS REPORT (ROAD MAP)}

The main body of this document defines specific conditions which can present flammable gas hazards, identifies the two conditions currently being evaluated, and discusses the methods for evaluating tanks regarding these two conditions. The main body contains enough details for the reader to understand how the evaluation is done. Attachments contain additional information for in-depth understanding and for conducting the evaluation.

Section 2.0 defines four flammable gas conditions in which gas from the waste might exceed safe limits and be a factor in the release of waste to the environment, and it compares the magnitudes of the release events. Section 2.0 also identifies the two concerns currently being evaluated and gives the logic for applying the methodology. The section refers to Attachment I for discussion of conditions not currently evaluated.

Section 3.0 discusses the tank data required for the evaluation. 
Section 4.0 describes the evaluation of the steady-state condition.

Section 5.0 describes the detailed logic for evaluating an episodic gas release (EGR) in the tanks.

Sections 6.0,7.0 and 8.0 discuss the three methods used to evaluate the potential hazard of an EGR: the "quick screen" based on the release rate per volume of slurry for tank $241-S Y-101^{1}$, the evaluation based on surface-level rise, and the evaluation based on barometric slope.

Section 9.0 discusses the evaluation of other factors that might cause a tank to exceed the criteria, for example, being connected by a cascade line to a tank which could exceed the criteria.

Attachments (Atch) contain information primarily of interest to those evaluating tanks:

Atch Content/Purpose

A Includes a collection form for tank data.

B For convenience and background, reproduces Appendix E of WHC-EP-0702, Rev. 0 (Hopkins 1994), which presents logic diagrams and discusses the assumptions behind and details of the calculation of flammable gas concentration.

C Contains instructions for using the Microsoft Excel ${ }^{2}$ spreadsheet prepared by S. A. Barker to help standardize the methodology; a printout of a spreadsheet; and a DSI by S. A. Barker providing background for the calculation of liquid evaporation from tank waste.

D Discusses uncertainties in surface level measurements.

E Discusses the technical basis for assuming the location of the center of trapped gas.

F Standardizes the distributions for inputs to Monte Carlo analysis.

G Ilustrates a distribution curve provided by Whitney for barometric slopes for a particular tank.

H Summarizes void fraction results for 103-SY.

I Presents information about plume burns and overpressurization, which were not evaluated by Hodgson et al. (1996), for subsequent evaluation.

J Presents the report of the Ogden-Piestrup committee, which on December 5 and 6, 1995 reviewed the methodology presented in this document; and includes a response to the committee's review report.

K Presents information on estimating evaporation in waste tanks.

L Discusses variations between barometric pressure measured at the Hanford Meteorological Station and pressure on the waste surface.

1 Waste tanks are hereafter referred to in abbreviated form; for example, SY-101.

2 Microsoft and Excel are registered trademarks of Microsoft Corporation, Redmond, WA. 
WHC-SD-WM-TI-724, Rev, 1

\subsection{FLAMMABLE GAS CONDITIONS AND LOGIC}

There are four flammable gas conditions which might be factors in a release of waste to the environment: the steady-state concentration of flammable gas in the tank headspace, the concentration after an episodic release of trapped gas, the ignition of a gas plume as it escapes from the waste, and overpressurization of a tank's exhaust filter caused by the release of pressurized gas from the waste.

The overall logic for evaluating tanks is based on a three-stage approach.

- When little or no tank-specific information is available to give an indirect or direct measure of a tank's gas content or releases, perform bounding (worst-case) calculations of potential gas releases/concentration using general information (for example, total waste volume, surface level history, type waste) and information about tank SY-101 and other flammable gas tanks.

- When indirect measures of a tank's trapped gas content/releases or headspace concentration become available, use this information to improve the calculations. If direct measures are already available, this step may be skipped.

- When direct measures become available, use this information to further improve the calculations.

The current evaluation is limited to considering the steady-state concentration and the concentration after an episodic release. Neither a plume bum nor overpressurization were included in the evaluation reported by Hodgson et al. (1996). However, information on these concerns is included in Attachment I for subsequent evaluations.

In addition to the four specific areas of concern, there is a general concern regarding other potential hazards, such as flammable gas flowing into a tank through a cascade line from an adjacent tank. If a flammable gas mixture in a tank subsystem, such as exhaust ducting, can attain the threshold level of any of the four criteria and has credible potential to cause a serious release, this is a basis for the tank failing the criteria. 
WHC-SD-WM-TI-724, Rev. 1

This page intentionally left blank. 


\subsection{TANK DATA REQUIREMENTS}

Evaluations must be based on reliable data. For consistency, data for different tanks should be taken from the same source, where practical. For example, current waste surface levels should be taken from the Personal Computer Surveillance Analysis Computer System (PC-SACS) database.

To facilitate careful data collection, an evaluator collects tank data on a data collection form (see Attachment A). The evaluator signs the final form (or a final printout of the data section of the Excel $^{\mathrm{T}}$ spreadsheet) and includes it in the tank evaluation record.

When two data sets measure the same parameter and are used in the same way, the higher quality data takes precedence. For example, all other things being equal (for example, same number of replicate measurements), measures of surface level variation taken by ENRAF surface level gauges (resolution \pm 0.01 in., or $0.25 \mathrm{~mm}$ ) take precedence over measures taken by Food Instrument Corporation (FIC) gauges (resolution \pm 0.1 in., or $0.25 \mathrm{~mm}$ ); and FIC measures take precedence over measures taken by manual tape (MT) (resolution \pm 0.25 in., or $0.64 \mathrm{~mm}$ ).

In some cases, data taken from tank photographs can be of higher quality than data taken with surface level devices. For example two photographs of a tank's saltwell pool taken ten years apart can show unequivocally how large the change was in the liquid surface level between the times of the photographs. Depending on other factors, the change determined from the photographs might be more reliable than the change determined from surface level devices. 
WHC-SD-WM-TI-724, Rev. 1

This page intentionally left blank. 


\subsection{EVALUATION OF STEADY-STATE CONCENTRATION}

For more than three dozen tanks, direct measurements of the steady-state flammable gas concentration have been obtained by careful sampling and analysis. The bounding steady-state concentration was calculated as described in this section. Because the calculations are conservative, sample results take precedence over calculations.

The steady-state concentration of flammable gas in a tank's headspace is a function of how fast gas is added to and exhausted from the headspace. The evaluation methodology conservatively assumes that none of the daily gas generation is trapped, that is, as soon as it is generated, all gas is added to the gas in the headspace. Therefore, the bounding rate of gas addition to the headspace equals the bounding gas generation rate. On the other hand, the rate at which gas is exhausted from the headspace is the sum of contributing rates described in Section 4.2 below.

The calculation of generation rates, exhaust rates, and bounding steady-state concentration are explained in the following sections.

\subsection{GAS GENERATION RATE}

The gas generation rate is the sum of generation rates for three mechanisms: radiolytic decomposition of water and organic compounds, thermal decomposition (thermolysis) of organic compounds, and corrosion of the metal tank. The bounding generation rates for each mechanism are defined based on rates in tank SY-101 (Hopkins 1994). Appendix E of that document is reproduced in Attachment $\mathrm{B}$ of this document. Bounding calculations are illustrated below.

\subsubsection{Radiolysis}

The rate of $\mathrm{H}_{2}$ generation by radiolysis is the product of power load and $\mathrm{G}\left(\mathrm{H}_{2}\right)$, where $\mathrm{G}\left(\mathrm{H}_{2}\right)$ is a measure of the rate of $\mathrm{H}_{2}$ generation per 100 electron volts $(\mathrm{eV})$, where electron volts are a measure of power. Heat loads are greater than or equal to power loads, and may be used in place of power load to calculate conservative radiolytic generation rates. Heat loads are provided by Graves (1994). Hopkins (1994) assumed the bounding $\mathrm{G}\left(\mathrm{H}_{2}\right)$ value to be 0.100 molecules $\mathrm{H}_{2} / 100$ electronvolts (eV). However, Graves (1994) calculated somewhat lower values for the tank safety basis, and these values were used in the evaluation. A sample calculation of the bounding radiolytic generation rate for tank S-106 is given below. For further information, see Attachment B, Section 4.4 .

$$
\begin{array}{ll}
\mathrm{G}\left(\mathrm{H}_{2}\right): & 0.067 \text { molecules } \mathrm{H}_{2} / 100 \mathrm{eV} \text { (Graves 1994) } \\
& \left(6.2415 \times 10^{15} \text { molecules } \mathrm{H}_{2} / \mathrm{J}\right)
\end{array}
$$

Heat load: $\quad 1135$ watts (Graves 1994)

$$
\begin{aligned}
\text { Rate for S-106: } & \\
\text { Rate }= & \text { power load } \times \mathrm{G}\left(\mathrm{H}_{2}\right) \\
\text { Rate } \leq & \text { heat load } \times \mathrm{G}\left(\mathrm{H}_{2}\right) \\
\text { Rate } \leq & 1135 \text { watts } \times 1 \mathrm{~J} / 2.7778 \times 10^{-4} \text { watt-h } \\
& \times 6.2415 \times 10^{15} \text { molecules } \mathrm{H}_{2} / \mathrm{J}
\end{aligned}
$$




$$
\begin{aligned}
& \times 1 \mathrm{~mole} / 6.022 \times 10^{23} \text { molecules } \mathrm{H}_{2} \\
& \times \quad 0.024463 \mathrm{~m}^{3} \mathrm{H}_{2}\left(25^{\circ} \mathrm{C}\right) / \text { mole } \mathrm{H}_{2} \times 24 \mathrm{~h} / \text { day } \\
& \quad \text { Rate } \leq .017 \mathrm{scm} \mathrm{H}_{2} / \text { day }\left(25^{\circ} \mathrm{C}, 101.3 \mathrm{kPa}\right) \\
& \left.\left(0.59 \mathrm{scf} \mathrm{H}_{2} / \text { day (standard cu. ft., } 1.00 \mathrm{~atm}, 25^{\circ} \mathrm{C}\right)\right)
\end{aligned}
$$

\subsubsection{Thermolysis}

A sample calculation of the bounding thermolytic generation rate for tank S-106 is given below. For further explanation, see Attachment B, para. 4.3.2.

Overall Calculation:

$$
\begin{aligned}
& \text { Rate/vol. liquid }=2.34 \times 10^{-4} \mathrm{scm} \text { gas } / \mathrm{m}^{3} \text { liquid/day } \\
& \left(2.34 \times 10^{-4} \mathrm{scf} \text { gas/ } / \mathrm{ft}^{3} \mathrm{liquid} / \text { day }\right)
\end{aligned}
$$

TOC ratio:

S-106\% TOC: $\quad 0.500 \%$ (Toth et al. 1995)

SY-101 \% TOC: $\quad 1.07 \%$ (Attachment B, para. 4.3.1)

S-106/SY-101: $\quad 0.500 \% / 1.07 \%$

Aluminate ratio ${ }^{3}$;

S-106\% Al:

SY-101\% Al:

S-106/SY-101:
$3.07 \%$ (Toth et al. 1995)

3.00\% (Attachment B, para. 4.3.1)

$3.07 \% / 3.00 \%$

Chemical Rate ratio:

Activation Energy, $\mathrm{E}_{\mathrm{a}}: 26,000 \mathrm{~J}$ (Attachment B, para. 4.3.1.8)

For S-106

$$
\text { Temp: }
$$

$298^{\circ} \mathrm{K}$

$$
\mathrm{e}^{-\mathrm{E}_{2} / R T} \text { : }
$$$$
\mathrm{e}^{-26,000 /(8.3134 \times 298)}
$$

For SY-101

$$
\text { Temp: }
$$$$
319.3^{\circ} \mathrm{K}
$$

$$
e^{-E_{a} / R T:}
$$

$$
\mathrm{e}^{-26.000 /(8.3134 \times 319.3)}
$$

Rate ratio:

$$
\begin{aligned}
& \mathrm{e}^{-26,000 /(8.3134 \times 298)} / \mathrm{e}^{-26,000 /(8.3134 \times 319.3)} \\
& =0.497
\end{aligned}
$$

3 Per Hopkins (1994), all aluminum in solution is assumed to be aluminate for this calculation. 
Overall Rate (Hopkins 1994, p. E-13):

Vol. of liq., S-1064: $1143 \mathrm{~m}^{3}\left(40,354 \mathrm{ft}^{3}\right)$

Rate $=101-S Y$ rate/vol. of liquid $\times$ S-106 vol. of liq. $\times$ TOC ratio $\mathrm{x}$ Al ratio $\mathrm{x}$ rate ratio

$=2.34 \times 10^{-4} \mathrm{scm}$ gas $/ \mathrm{m}^{3}$ liquid/day $\times 1143 \mathrm{~m}^{3} \times$ $0.500 \% / 1.07 \%$ x $3.07 \% / 3.00 \%$ x 0.497

$=0.064 \mathrm{scm}$ gas/day $(2.25 \mathrm{scf}$ gas/day $)$

\subsubsection{Corrosion}

A sample calculation of the bounding corrosion generation rate for tank S-106 is given below. For further explanation, see Hopkins 1994, p. E-13.

Rate for SY-1015: $2.637 \times 10^{-5} \mathrm{scm} /$ day $/ \mathrm{m}^{2}$ wet steel

$\left(8.65 \times 10^{-5} \mathrm{scf} /\right.$ day $/ \mathrm{ft}^{2}$ wet steel $)$

Rate for S-106:

$$
\begin{aligned}
\text { Rate } & =2.637 \times 10^{-5} \mathrm{scm} / \text { day } / \mathrm{m}^{2} \text { wet steel } \\
& \quad \mathrm{x} \text { area exposed to waste } \\
= & 2.637 \times 10^{-5} \mathrm{scm} / \text { day } / \mathrm{m}^{2} \text { wet steel } \times 736.3 \mathrm{~m}^{2} \\
= & 0.019 \mathrm{scm} / \text { day }(0.69 \mathrm{scf} / \text { day })
\end{aligned}
$$

\subsubsection{Total $\mathrm{H}_{2}$ Generation}

The bounding daily generation rate is the sum of the three rates determined above:

$\begin{array}{ll}\text { Radiolysis } & 0.017 \\ \text { Thermolysis } & 0.064 \\ \text { Corrosion } & 0.019 \\ \text { TOTAL } & 0.100 \mathrm{scm} / \text { day }(3.53 \mathrm{scf} / \text { day })\end{array}$

4 The volume of liquid in the tank is determined by adding the volume of supernate to the volume of interstitial liquid in saltcake and sludge. The volume of interstitial liquid is determined by multiplying the volume of wet solids by the solids' porosity. (This liquid volume may be reduced by gas volume if it is known.) If there is no supernate, the top of wet solids is determined from the interstitial liquid level. Additional details are included in the explanation of the Excel $^{\text {TM }}$ spreadsheet in Attachment C.

5 Anantatmula et al (1994) have shown that the conservative corrosion rate for tank steel could be about four mils/year. four times the rate on which this generation rate is based. Therefore, the rate used here may be increased when Hopkins 1994 is revised. 


\subsection{TANK VENTILATION RATE}

The tank ventilation (exhaust) rate is the sum of the following five contributing rates:

- Mechanical exhaust. Double-shell tanks (DSTs) have mechanical exhausters, but most singleshell tanks (SSTs) do not. For mechanically exhausted tanks, none of the below-listed sources of air turnover were considered.

- Atmospheric breathing (exhalation and inhalation of headspace air with changes in barometric pressure). This breathing rate has been determined to be $0.45 \%$ per day of the headspace volume (Crippen 1993).

- FIC purge air flow. FIC gauges are equipped with purge air to prevent freeze-up. The minimum flow is about $1.70 \mathrm{~m}^{3} / \mathrm{h}(60 \mathrm{cfh})$. However, because the air flow is not required by an operating specification document, and many tanks do not have this supplied air flow, the evaluation takes no credit for this flow.

- Convective flow. This flow occurs because warm air above the waste is lighter than atmospheric air outside the tank. In previous modeling studies, this flow has been found to be as high as an order of magnitude above the atmospheric breathing rate, depending on headspace temperature. This flow rate was not used in calculating the steady-state \% LFL reported as a result of this evaluation. If the rate can be determined, it should be used because it will reduce the calculated concentration by an order of magnitude or more.

- Bernoulli flow caused by wind blowing past the tank exhausts. This flow rate is intermittent and has not been determined, so it was not considered in the evaluation.

Analysis of existing tank data might provide a good estimate of a tank's overall exhaust rate (air turnover rate, air exchange rate, breathing rate). For example, because headspace air and air outside the tank are at different temperatures, and the headspace temperature in cooler tanks is largely determined by the tank's exhaust rate, it is possible to use the seasonal plot of headspace temperature to estimate exhaust rate. A better estimate of the rate might be made by modeling the tank's heat transfer, including transfer into/out of the waste, tank dome and surrounding soil. At this point, however, work to improve estimates of the exhaust rate is still in its early stages. Therefore, evaluation of steady-state concentration for passively ventilated tanks conservatively limited non-mechanical turnover to $0.45 \%$ per day, unless available data allowed using a higher rate. Additional discussion on determining the exhaust rate is included in the spreadsheet instructions in Attachment C.

\subsection{OVERall CALCULATiON}

The equation below is used to determine the bounding $\mathrm{H}_{2}$ steady-state concentration in the headspace, based on total generation rate and total exhaust rate.

$$
\text { Mole fraction of } \mathrm{H}_{2}=\frac{\text { total daily generation rate }}{\text { total daily generation rate }+ \text { exhaust rate }}
$$

For a daily gas evolution of $\mathrm{g} \mathrm{ft}^{3} \mathrm{H}_{2} / \mathrm{d}$, passively vented tanks, which have a daily breathing rate of 0.0045 times the tank's headspace volume (Crippen 1993), the equation is as follows.

$$
\text { Mole fraction of } \mathrm{H}_{2}=\frac{\mathrm{g} \mathrm{m}^{3} / \mathrm{d}}{\mathrm{g} \mathrm{m}^{3} / \mathrm{d}+0.0045 \text { (tank vol. - waste vol.) } \mathrm{m}^{3} / \mathrm{d}}
$$


For the generation rate calculated for tank S-106 in Section 4.1.4, the mole fraction is calculated as follows:

$$
\text { Mole fraction of } \mathrm{H}_{2}=\frac{0.100 \mathrm{~m}^{3} / \mathrm{d}}{0.100 \mathrm{~m}^{3} / \mathrm{d}+0.0045(2,168) \mathrm{m}^{3} / \mathrm{d}}=0.01014 \mathrm{H}_{2}
$$

As explained by Hopkins (1994), assume the $\mathrm{NH}_{3}$ concentration is four times, and the methane concentration is 0.02 times, the $\mathrm{H}_{2}$ concentration; and calculate the percent lower flammability limit (\% LFL) as follows:

$$
\begin{aligned}
\% \mathrm{LFL} & =\mathrm{n}_{\mathrm{H}_{2}} / \mathrm{LFL}_{\mathrm{H}_{2}}+\mathrm{n}_{\mathrm{NH}_{3}} / \mathrm{LFL}_{\mathrm{NH}_{3}}+\mathrm{n}_{\mathrm{CH}_{4}} / \mathrm{LFL}_{\mathrm{CH}_{4}} \\
& =(0.01014 / 0.04+0.04056 / 0.15+0.0002 / 0.048) \times 100 \% \\
& =52.8 \%
\end{aligned}
$$

\subsection{SPREADSHEET}

The calculations described in this section are performed by an Excel ${ }^{\mathrm{m}}$ spreadsheet. A printout of the spreadsheet is included in Attachment C.

\subsection{SAMPLING}

For about $30 \%$ of the $50+$ tanks sampled so far, the ratio of calculated $\mathrm{H}_{2}$ concentration to sample $\mathrm{H}_{2}$ concentration varies from 0.2 to 10 . For almost $50 \%$ of the tanks, the ratio varies from 10 to 100. For the remaining tanks, the ratio is over 100 . For one tank, the ratio is almost 700 . This difference results partly because the calculation of the generation rate is conservative and partly because the exhaust rate (the breathing rate, $0.45 \%$ ) used in the calculation is lower than the actual exhaust rate. Therefore, whenever calculated steady-state values exceed the criterion limit, it is desirable to determine the actual value by sampling. The maximum steady-state concentration measured by sample so far was $5.2 \%$ of the LFL, in tank SX-109. 
WHC-SD-WM-TI-724, Rev. 1

This page intentionally left blank. 
WHC-SD-WM-TI-724, Rev. 1

\subsection{EVALUATION OF EGR: LOGIC}

Attachment B defines the detailed logic for applying the Flammable Gas Watch List (FGWL) criterion for EGRs. The logic is taken from Figure E-2 in Criteria for Flammable Gas Watch List Tanks, WHC-EP-0702, Rev. 0 (Hopkins 1994), which is reproduced in Attachment B of this document. The logic diagram, which appears on page B-23, is discussed in the paragraphs below.

The first question in the logic is, "Does tank already have EGRs?" If the answer is "yes," the evaluator can proceed directly to the quick screen discussed in Section 6.0. If the answer is "no," the evaluator goes to the second question, "Is tank empty?" Because only one of 177 tank is empty, for 176 tanks the third question is, "Is the waste too rigid for EGR?" Present knowledge is insufficient to establish how rigid waste must be before it can no longer have an EGR. The EGRs in tank 101-SY have occurred in the form of rollovers, in which gas-containing waste in the nonconvecting (settled-solids) layer attains a lesser density and rises quickly through the convecting layer (fluid layer). It has been suggested that a rollover cannot occur unless settled solids are covered with a layer of supernate. However, an EGR might occur in other forms such as the release of large (for example, one-meter-diameter) bubbles or the release of gas pockets via a chimney through the waste. ${ }^{6}$ Whatever the mechanism, from fumaroles (craters) in photographs such as the one of tank T-107 in Figure 5-1, it appears possible that gas plumes might occasionally escape from solids in EGRs. Therefore, until shown otherwise, it is assumed that gas can be released from any waste which can accumulate quantities of trapped gas.

Because gas can only be trapped in solids, the fourth question in the logic is, "Is waste all liquid?" If the answer is "no," the fifth question "Waste contains organics, can precipitate \& has high H2 generation?"concerns whether a tank can trap flammable gas. This question applies to tanks having no indirect or direct measures of volume of trapped gas. For tanks in which surface level growth and/or a negative barometric slope are indirect measures indicating that tanks are trapping gas, skip the question, and proceed directly to the sixth question, "QUICK SCREEN: Could EGR exceed $25 \%$ of the LFL?" This question is addressed in Section 6.0. If the quick screen indicates that the tank being considered could exceed $25 \%$ of the LFL, the next step is to use indirect measures (for example, surface level growth and barometric slope) to answer the question, "FULL EVAL'N: Could EGR exceed 25\% of the LFL?" This question is addressed in Sections 7.0 and 8.0 .

6 Per personal communication on December 1, 1995 with C. W. Stewart. Stewart confirmed this view is reflected in a document he signed for R. T. Allemann (1995). 
Figure 5-1. Fumaroles in Tank 241-T-107.

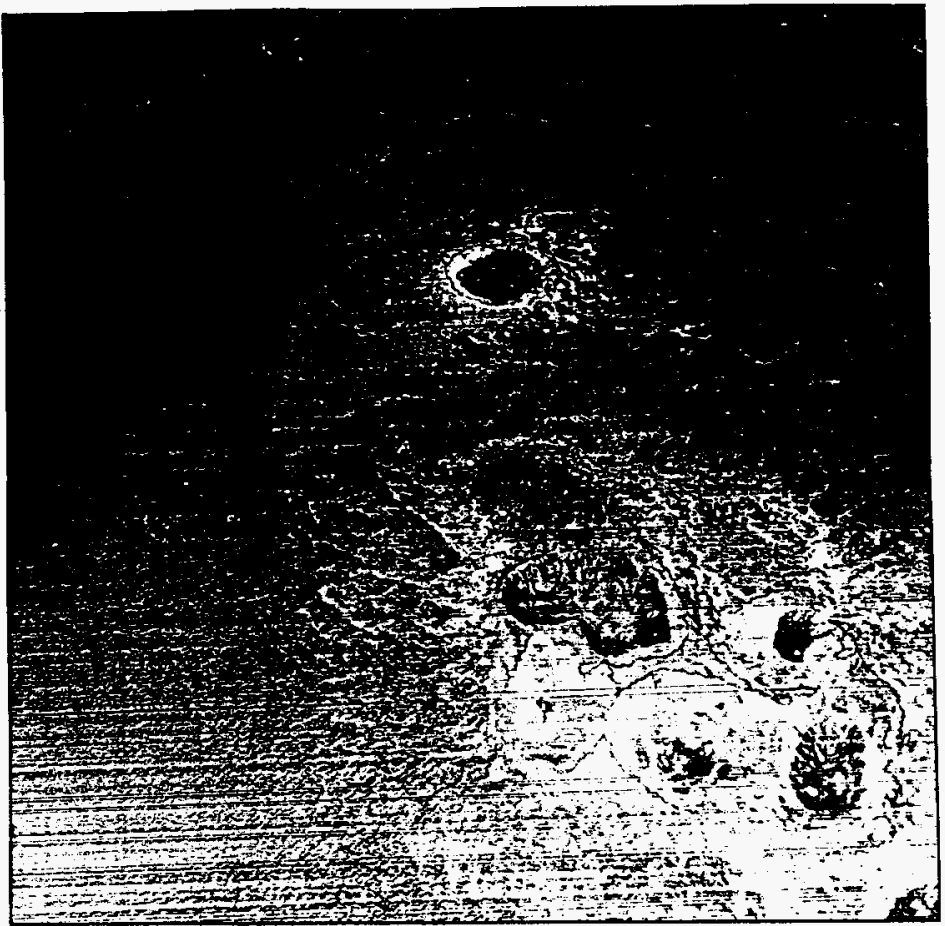

This photograph shows fumaroles in the waste surface of tank T-107. The fumaroles suggest that pockets of gas repeatedly escaped in specific areas. 


\subsection{EVALUATION OF EGR: QUICK SCREEN VS. TANK 101-SY}

As prescribed by Hopkins (1994, p. E-23), a "quick screen" was done on each tank to determine whether it could have an EGR which would exceed $25 \%$ of the LFL if the tank released gas at the same ratio per volume of waste as tank SY-101 did in its bounding release. Because this case bounds all other cases discussed below, if a tank passed this screen, it was given no further evaluation to determine whether it could exceed the EGR criterion.

In its largest release, tank SY-101 released $0.0735 \mathrm{ft}^{3}$ (in situ volume, or compressed volume) of gas per $\mathrm{ft}^{3}$ of the nonconvecting (solids) layer. It is assumed that each SST could release gas occupying a compressed volume equal to $7.35 \%$ of the solids volume, and the resulting \% LFL is calculated, including ammonia concentration. The calculation is illustrated below for tank S-106.

$\begin{array}{lrll}\text { Given: } & & & \\ \text { Solids surface level } & 453.7 & \mathrm{~cm} & (178.62 \mathrm{in} .) \\ \text { Atmospheric pressure } & 101.4 \mathrm{kPa} & \left(14.7 \mathrm{psi}^{7}\right) \\ \text { Head on gas } & 51.3 \mathrm{kPa} & (7.44 \mathrm{psi}) \\ \text { Temperature of gas } & 298.1 \mathrm{~K} & \left(536.6^{\circ} \mathrm{R}\right) \\ \text { Dish volume } & 47.3 \mathrm{~m}^{3} & \left(1671 \mathrm{ft}^{3}\right) \\ \text { Headspace } & 2828 \mathrm{~m}^{3} & \left(82,211 \mathrm{ft}^{3}\right) \\ \text { Fraction } \mathrm{H}_{2} \text { in trapped gas } & 0.97 & & \\ \text { Fraction of } \mathrm{NH}_{3} \text { released } & 0.220 \mathrm{~m}^{3} \mathrm{NH}_{3} / \mathrm{m}^{3} \text { released gas } \\ & \left(0.220 \mathrm{ft}^{3} \mathrm{NH}_{3} / \mathrm{ft}^{3} \text { released gas) }\right.\end{array}$

$$
\begin{aligned}
\text { Solids vol. }{ }^{10} & =410.4 \mathrm{~m}^{3} / \mathrm{m}(\text { surface level, } \mathrm{m}-\text { dish, } \mathrm{m})+47.3 \mathrm{~m}^{3} \text { dish } \\
& =410.4 \mathrm{~m}^{3} / \mathrm{m}(4.537 \mathrm{~m}-0.3048 \mathrm{~m})+47.3 \mathrm{~m}^{3} \\
& =1784.2 \mathrm{~m}^{3} \text { solids }\left(63,020 \mathrm{ft}^{3}\right) \\
\text { Vol. trapped } & =1784.2 \mathrm{~m}^{3} \text { solids solids } \times 0.0735 \mathrm{ft}^{3} \text { trapped gas } / \mathrm{ft}^{3} \text { solids } \\
& =131.1 \mathrm{~m}^{3} \text { trapped gas }\left(4,631 \mathrm{ft}^{3}\right)
\end{aligned}
$$

7 The abbreviation psi is used throughout this document in lieu of $\mathrm{lbf} / \mathrm{in}^{2}$.

8 To shorten the calculation in the initial screen of a tank, the evaluator may use the pre-release headspace volume, as is done here. However, it is more accurate to use the post-release volume, which is larger than the pre-release volume and therefore gives a lower \% LFL. In the example shown here, the increase in headspace is $198.1 \mathrm{~m}^{3}$. This results in a \% LFL of 202 instead of the 219 calculated here.

9 In Hopkins 1994, this fraction was 0.259 for tank 101-SY. A small part of this fraction of $\mathrm{NH}_{3}$ was emitted from the trapped slurry gas which was released; the larger part of the fraction was emitted by mass transfer of $\mathrm{NH}_{3}$ from the waste brought to the surface by the rollover. Appendix E of Hopkins 1994 (See Section 5.3.4 of Attachment $B$ of this methodology document) assumes a release of $0.259 \mathrm{~m}^{3} \mathrm{NH}_{3} / \mathrm{m}^{3}$ released gas when trapped gas is $97 \% \mathrm{H}_{2}$. However, this methodology document recognizes that trapped gas containing $97 \% \mathrm{H}_{2}$ would contain no $\mathrm{NH}_{3}$, so it is assumed that the waste releases only $0.220 \mathrm{~m}^{3} \mathrm{NH}_{3} / \mathrm{m}^{3}$ released gas.

10 In most calculations in this document, more digits are shown in the calculated results than are justified by the number of significant digits in the inputs to the calculation. This is done to avoid rounding errors in successive calculations, and to show agreement with calculations done by the Excel ${ }^{T M}$ spreadsheet, which carries all digits forward in successive steps of the calculation. 


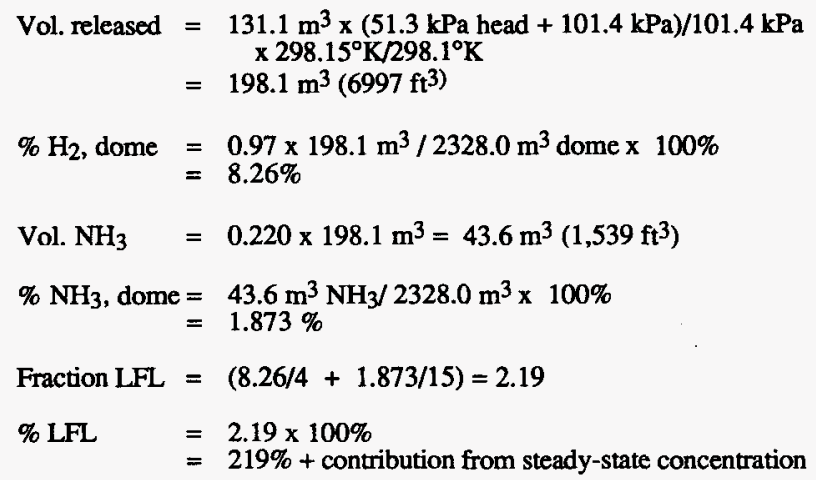

The results show the tank could release enough flammable gas to exceed $25 \%$ of the LFL. The tank requires further evaluation if indirect or direct measures of trapped gas are available. 


\subsection{EVALUATION OF EGR BASED ON SURFACE LEVEL RISE}

One of the parameters that indicated trapped gas in the 1990 FGWL screening was a surface level | rise (Hopkins 1994). A surface level rise can result from other factors besides trapped gas (for example, rainwater intrusion), but the 1995-96 evaluation team assumed it resulted from trapped gas. In addition to this parameter, the team recognized a rising interstitial liquid level (ILL) as a possible indicator of trapped gas, even for a tank with a constant or falling surface level.

Figure 7-1 is a surface level plot for tank S-106, showing about 18 inches of surface level rise. Figure 7-2 is an interstitial liquid level plot for tank TX-112, showing about 20 inches of level rise. Such plots were used as the starting point for calculating the amount of trapped gas a tank's waste could contain.

Figure 7-1. Surface Level Plot for Tank 241-S-106.

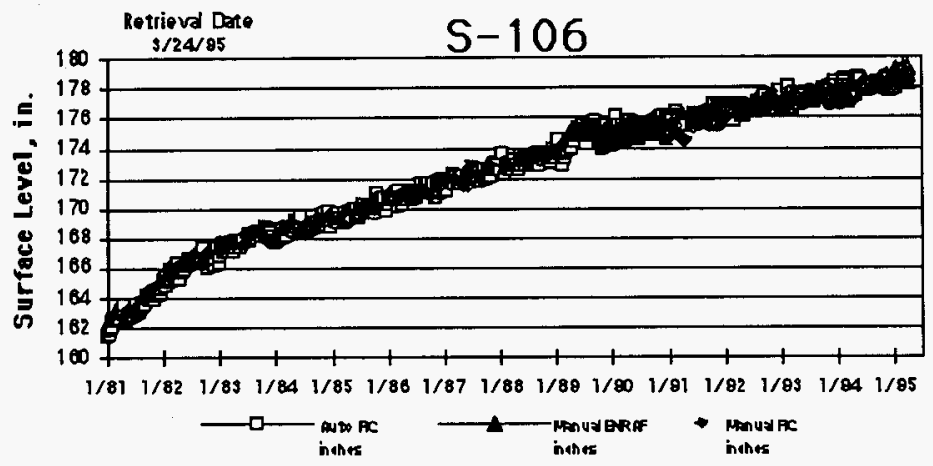

Figure 7-2. Interstitial Liquid Level Plot for Tank 241-TX-112.

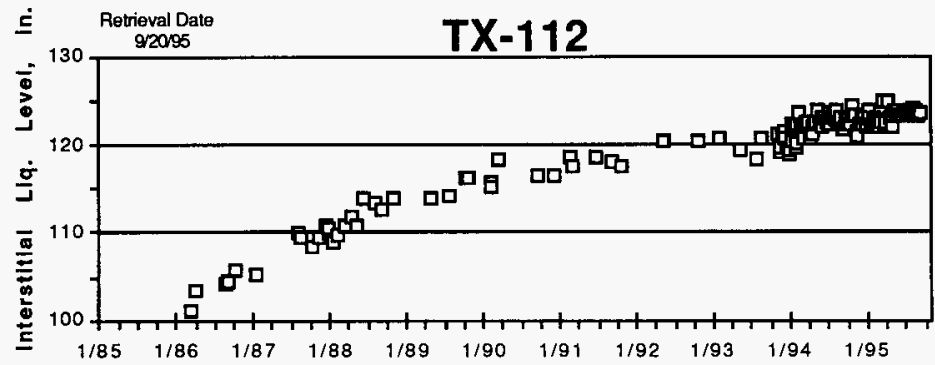


The methodology for using level rise data to calculate the amount of trapped gas and the \% LFL attainable in the headspace if part of that gas were released is illustrated in the following subsections.

\section{1 GENERAL}

The concept underlying the methodology assumes the increase in waste volume shown by a level rise equals the increase in in situ volume of trapped gas. To determine the \% LFL the tank could attain, determine the level rise, the location of the trapped gas and its temperature and pressure, and the fraction that can be released to the headspace, then calculate the attainable \% LFL.

Applying the concept can be challenging. For example, sometimes data (especially for $\mathrm{ILL}$ ) are only available for parts of a tank's history, so the evaluator must estimate interim or previous data. Moreover, there is a need to make adjustments to the level for potential surface level changes that have nothing to do with gas content. For example, the Tank Advisory Panel (TAP) has noted that considerable evaporation can occur from liquid on the waste surface over a 15-year period, thereby masking some level rise. Work to account for these factors has recently begun. Thurgood and Ogden (1995) began to examine the effects of evaporation, and they defined a method for evaluating the effect of evaporation on surface level rise (See Attachment K). The evaluations reported by Hodgson et al. (1996) incorporated their method for tanks with a liquid surface.

Except for the data from tank SY-101, the available psychrometric and vent flow data for tanks are of poor quality; therefore, the error band around the amount of evaporation calculated from the data is wide. Moreover, the bounding evaporation calculated in the absence of such data is based on conservative assumptions for both flow and relative humidity, and this contributes to conservatism in the bounding calculation. These assumptions were necessary when using the tool for general screening purposes. These results can be improved and conservatism removed by a careful application of the method supplemented with additional thermal hydraulic analyses to better define controling parameters such as flow and humidity. This area of the methodology should be improved in the future to remove excess conservatism from the calculation of trapped gas volume based on surface level rise.

Other adjustments besides evaporation have not yet been defined. In any case, the following methodology allows making such adjustments.

\section{2 DETERMINE THE LEVEL INCREASE}

Determine the cumulative surface level rise. If there is no cumulative rise, this method cannot be used. The lack of a surface level rise may indicate that there is not a significant amount of trapped gas in the waste, or it may mean that other factors (for example, leakage from the tank) mask the level rise. If there is a cumulative rise, calculate the volume of trapped gas as follows:

$$
\begin{aligned}
\text { Level Rise }= & \text { (current level) - (level at start of measurement period) } \\
& + \text { (accumulated level rise before measurement period) } \\
& + \text { (potential losses during period) } \\
& - \text { (known additions during period) }
\end{aligned}
$$

Potential losses and additions before or during the measurement period include the following:

- Losses: evaporation, compaction, leakage, supernate volume pumped from tank, measuring error (icicle on FIC at initial reading or kink in tape at current reading), and gas already trapped 
in the solids at initial reading. Three methods of estimating evaporation, and how to decide which method to use, are discussed in Attachment C.

- Additions: intrusions (in-leakage), condensate from ambient air dripping into waste, hygroscopic absorption of moisture from the air by hydroxide in the waste, crust expansion by gas since start date (subtract it because it is assumed gas in the crust can't be released during an | EGR of gas from down in the waste), crystal expansion since the initial reading, slumpinginduced displacement, measuring error (icicle on FIC plummet on current reading, for example, 1980), and kink in tape at initial reading.

In addition to the losses and additions mentioned above, there are uncertainties arising from the position of the surface level gauge, as discussed in Attachment D.

This method was initially used only for supernate surfaces or exposed solid surfaces. However, the evaluation team also used it for interstitial liquid levels and, in a few cases, submerged solids levels. For these uses, many of the additions and subtractions are not applicable.

The following conservative practice is defined: add inches for any contributing factor that reasonably could have happened, unless the evidence is conclusive that it did not happen; and do not subtract for any contributing factor unless the evidence is conclusive that it actually did happen. The current evaluation has not been able to quantify the contributing factors. Effort may be dedicated to this part of the evaluation as refinements are made to the methodology. For the present, it should be recognized that there is a great deal of uncertainty in the analysis of surface level rise, and that the actual amount of trapped gas can be significantly different than the analysis indicates. This uncertainty is not included in any Monte Carlo analysis (See Section 7.7) done on the surface level analysis.

\section{3 CALCULATE TRAPPED (IN SITU, COMPRESSED) GAS VOLUME.}

If the level change is for the waste surface level, use the following formula:

$$
\begin{aligned}
\text { Trapped vol. }= & 410.4 \mathrm{~m}^{3} / \mathrm{m} \text { of rise } \mathrm{x} \mathrm{m} \text { of rise } \\
& \left(\mathrm{or}, 368.2 \mathrm{ft}^{3} / \mathrm{in} \text {. of rise } \mathrm{x}\right. \text { in. of rise) }
\end{aligned}
$$

If the level change is for the interstitial level, use the following formula:

$$
\begin{aligned}
\text { Trapped vol. } & =410.4 \mathrm{~m}^{3} / \mathrm{m} \text { of rise } \mathrm{x} \text { m of rise } \mathrm{x} \text { porosity } \\
& =\left(\text { or, } 368.2 \mathrm{ft}^{3} / \mathrm{in} \text {. of rise } \mathrm{x} \text { in. of rise) } \mathrm{x}\right. \text { porosity }
\end{aligned}
$$

Check the calculated trapped volume to insure it does not correspond to a void fraction greater than 0.300 (See Attachment F).

$$
\text { Void Fraction }=\text { trapped gas volume/wet-solids volume }
$$

If the void fraction exceeds 0.300 , truncate it to a volume corresponding to 0.300 when calculating the amount of trapped gas released. 


\section{4 CALCULATE VOLUME OF HYDROGEN RELEASED TO HEADSPACE}

To calculate the volume of $\mathrm{H}_{2}$ released to headspace, do the following:

1. Assume the average distance of the gas above tank bottom is $0.225 \mathrm{x}$ the height of wet solids measured at tank center (See Attachment E). Gas is assumed to be trapped in wet solids below the liquid level but not in the supernate or in the dry solids above the liquid level. Attachment $E$ shows plots of tentative void fraction measurements of tank SY-103. The mid-point of the gas is deduced to be 0.61 to $0.914 \mathrm{~m}$ (24 to $36 \mathrm{in}$.) from the tank bottom in a solids layer $3.35 \mathrm{~m}$ (132 in.) deep. Thus, the center of the trapped gas is assumed to be no higher than $22.5 \%$ of the wet-solids height above the bottom of all tanks measured at tank center.

2. For SSTs, assume $25 \%$ of trapped gas is released to the headspace. Because most SSTs are passively ventilated, gas released from the waste accumulates in the headspace. Thus, a prolonged release that occurs in an SST results in the same flammable gas concentration in the headspace as a near-instantaneous release in a DST.

For DSTs, also assume $25 \%$ of trapped gas is released to the headspace. Note however that in I mid-November 1995, Los Alamos National Laboratory performed a Raleigh-Taylor evaluation on DST 101-AY and predicted a bounding overall release of $47 \%$. An overall release of $54 \%$ (over a several-day period) has been credited to tank 101-SY, with a prompt release (within several minutes or an hour) of $39 \%$. Because the tank 101-AY $47 \%$ overall release is less than the tank 101-SY 54\%, the tank 101-AY prompt release is likely to be less than the tank 101-SY $39 \%$ but may be larger than $25 \%$.

The assumed $25 \%$ release is believed to be conservative. Examination of data about the most active DSTs on the Flammable Gas Watch List (except for tank SY-101, which has been mitigated) shows that none of these DSTs has had a release fraction of more than 0.21 (Shepard, et al. 1995). SSTs are expected to have lower release fractions than DSTs. Under catastrophic conditions, such as an earthquake, a larger percent of the trapped gas is likely to be released, especially if the quake propels the trapped gas upward by exerting a substantial upward force on the waste. Scientists at Pacific Northwest National Laboratory (PNNL) are investigating the issue of release fraction under normal and earthquake conditions. Until PNNL determines the bounding release fraction, results of evaluations against the FGWL episodic-release criterion should be considered tentative.

3. Calculate the volume of released gas.

4. Calculate the volume of $\mathrm{H}_{2}$ released, assuming $97 \%$ of gas is hydrogen. This conservative percentage is based on an estimate that a release in tank $\mathrm{AW}-101$ might have been as high as $74 \%$ hydrogen and a release in tank $105-\mathrm{AN}$ may have exceeded $90 \% \mathrm{H}_{2}$. (Note however that retained-gas sampling in tank AW-101 in the last few months indicates its trapped gas contains less than $20 \% \mathrm{H}_{2}$.)

\section{5 Calculate volume of THE headsPaCe}

To calculate the volume of the tank headspace, do the following:

1. Determine the total tank volume from tank drawings.

2. Using the appropriate formula from Joncus (1982), determine the volume of the waste before the release.

3. From total tank volume, subtract waste volume after the gas release. 


\section{6 CALCULATE \% LFL IN THE HEADSPACE}

To calculate the \% LFL in the tank headspace, do the following:

1. Calculate $\% \mathrm{H}_{2}$ in the headspace.

2. Calculate $\% \mathrm{NH}_{3}$ in the headspace.

3. Add the $\% \mathrm{H}_{2}$ and $\% \mathrm{NH}_{3}$ to get combined \% LFL.

4. Add the combined \% LFL to the gas concentration already present from steady state (See section 4.0).

\section{7 . 7 ERROR BAND AROUND CALCULATED RESULT - MONTE CARLO ANALYSIS}

For calculations which predict a resulting condition such as those discussed above, each input parameter to the calculation has an error band, or range of possible values. The calculated result also has an error band; therefore, the question arises, "Where does the calculated result fall within the range of possible results?" or, "How conservative is this result?" One way to answer these questions is to perform a Monte Carlo analysis, which uses the range for each input parameter to determine the range for the calculated result. The analysis performs hundreds or thousands of calculations using a random-number generator to generate values throughout the range for each input parameter, and it compiles a distribution range for the predicted result.

The benefit of a Monte Carlo analysis is illustrated through the following hypothetical case. It is known that a source emitted gas for two hours with a standard deviation (SD) of 0.1 hours, and that the emission rate was $5 \mathrm{~m}^{3} / \mathrm{h}\left(\mathrm{SD}=0.5 \mathrm{~m}^{3} / \mathrm{h}\right)$. It is also known that the gas emitted was $50 \%$ hydrogen ( $\mathrm{SD}=2.0 \%$ ). How much $\mathrm{H}_{2}$ gas was emitted? A single calculation using mean values of input parameters yields a result of $5 \mathrm{~m}^{3}$ of $\mathrm{H}_{2}$ released $\left(5 \mathrm{~m}^{3}\right.$ gas $/ \mathrm{h} \times 2 \mathrm{~h} \times 0.5 \mathrm{~m}^{3} \mathrm{H}_{2} / \mathrm{m}^{3}$ gas $=$ $5 \mathrm{~m}^{3} \mathrm{H}_{2}$ ). A single calculation using values of input parameters two standard deviations above the mean (that is, at a level bounding $97.7 \%$ of the values for each parameter) yields a result of $7.1 \mathrm{~m}^{3}$ of $\mathrm{H}_{2}$ released $\left(6.0 \mathrm{~m}^{3}\right.$ gas $/ \mathrm{h} \times 2.2 \mathrm{~h} \times 0.54 \mathrm{~m}^{3} \mathrm{H}_{2} / \mathrm{m}^{3}$ gas $\left.=7.1 \mathrm{~m}^{3} \mathrm{H}_{2}\right)$. A Monte Carlo analysis shows that the hydrogen emissions could vary from 3.0 to $7.0 \mathrm{~m}^{3}$ at $99.9 \%$ certainty, with a range as shown in Figure 7-3. Therefore, the value 7.1 bounds about $99.9 \%$ of the possible values for $\mathrm{H}_{2}$ gas emitted.

For this simple illustration, it is not difficult to hand calculate the range of the result. However, for calculations with many input parameters, it becomes more difficult. On the other hand, the analysis is easily done with Monte Carlo software. 
Figure 7-3. Monte Carlo Distribution for Volume of $\mathrm{H}_{2}$ Emitted.

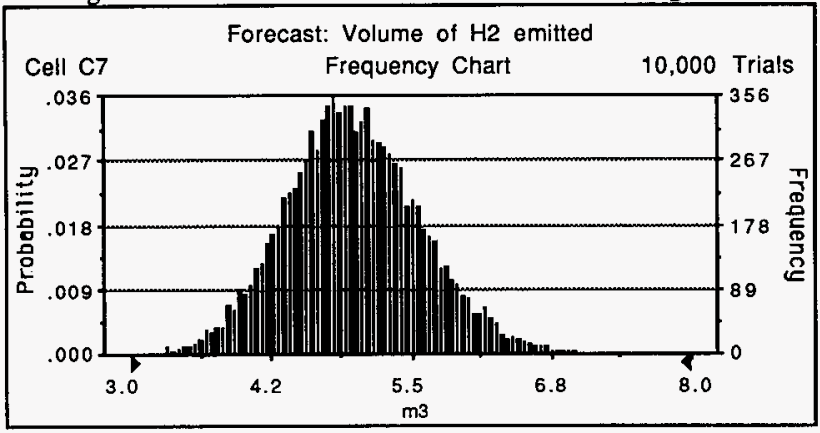

Monte Carlo analysis shows how individual parameters interact with each other and how much the parameters affect the calculated result. For the above case, Figure 7-4 shows the contribution the individual parameters make to the variance of the calculated result.

Attachment $\mathrm{F}$ includes further information about Monte Carlo analysis, including a printout of a Monte Carlo report for a tank evaluation. The analysis is used to show where a calculated value falls in the range of possible values and to determine the upper limit of the value range. The evaluator must check the upper limit, as well as the calculated value, to determine how the evaluated tank compares to the FGWL criteria. For example, if the calculated (deterministic) value is less than $25 \%$ of the LFL, but the Monte Carlo distribution shows the concentration can exceed $100 \%$ of the LFL at the upper limit of the range of values, this suggests to the evaluator that the deterministic calculation is not conservative enough, and the tank may need additional evaluation.

Figure 7-4. Sensitivity Chart: Contribution to Variance by Individual Parameters.

\section{Sensitivity Chart}

Target Forecast: Volume of H2 Emitted

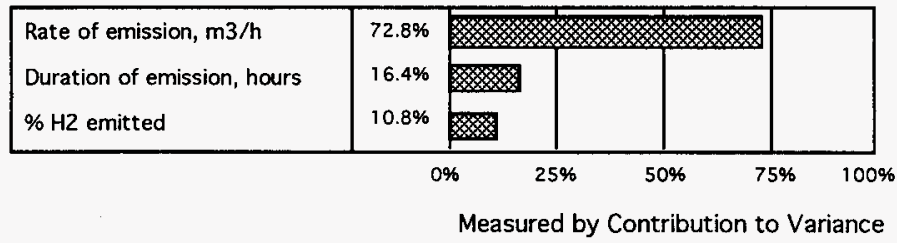

For a given set of values for input parameters, multiple runs of a 5,000-trial Monte Carlo analysis give a slightly different upper-limit (100-percentile) value, if the seed value (initial random number) is not the same for all runs. This reflects the effect the statistical variation of the input parameters has on the concentration. However, for runs of 5,000 trials, the 99-percentile value remains essentially the same with successive runs. 
As the number of runs is increased, the 100-percentile value increases because a larger number of trials allows the software to make more random selections near the upper limits of the ranges of the input parameter. Time and software/hardware restrictions make it impractical to perform very large (for example, 100,000-trial) runs. Such large runs are not justified anyway because they would assume we have precisely defined the input parameters. In fact, for most input parameters, the variation is based partly on engineering judgment and partly on knowledge of how measures of parameters vary statistically. To limit time spent on Monte Carlo analysis and to keep from extending the analysis beyond the quality of the input parameters, Monte Carlo runs are limited to 5,000 trials.

\subsection{SPREADSHEET}

The calculations in this section are performed by an Excel ${ }^{\text {TM }}$ spreadsheet. A printout of the spreadsheet is included in Attachment C. 
WHC-SD-WM-TI-724, Rev. 1

This page intentionally left blank. 


\subsection{ESTIMATE OF EGR BASED ON BAROMETRIC SLOPE}

A recent report by Whitney (1995) indicates the amount of gas trapped within a tank's waste, which can be used to estimate the amount of gas which could be vented into the headspace in an EGR. Whitney examined surface level data for all 177 waste tanks taken since about 1980 and found a significant correlation between surface level and the reciprocal of barometric pressure in 58 tanks, including 21 FGWL tanks. The correlation suggests the tanks contain trapped gas. These tanks have been further evaluated to determine the \% LFL attainable in the headspace if an EGR occurs.

For each tank, Whitney divided the years of data into intervals of about 60 days ( 15 days if level readings were taken daily), then calculated a slope $(\mathrm{dL} / \mathrm{dP}$, where $\mathrm{L}$ is surface level and $P$ is barometric pressure) for each interval, where the slope has a standard error (similar to standard deviation) which defines the range of the slope for each interval. The more negative the slope, the greater the volume of gas. This slope can be used to estimate the amount of gas trapped in the 58 tanks and the concentration of flammable gas that can be attained in the tank headspace from an EGR.

Whitney determined the distribution curve of slopes for recent history of the flagged tanks being evaluated, usually from January 1, 1990 to April 1995, but sometimes for a shorter, more recent period (see Attachment $\mathrm{G}$ ). In the attachment, the 0.25 quantile slope at -1.44 in./in $\mathrm{Hg}^{11}$ bounds $75 \%$ of the slopes, those less negative than or equal to $-1.44 \mathrm{in} / \mathrm{in}$. $\mathrm{Hg}$. Using this 75 th-percentile slope to calculate trapped volume is assumed to be conservative because slopes at this quantile predict a void fraction of over $30 \%$ in some tanks. Although the methodology predicts slopes this high, it is assumed that void fraction cannot exceed $30 \%$, as explained in Section 8.1, item 8.

To illustrate the methodology for using the slope to estimate the amount of trapped gas and the \% LFL attainable in the headspace after an EGR, this section shows the calculations for tank S-106. Although some data may differ from current data, the data are adequate to illustrate the calculations. The assumptions and the calculations are given below.

\section{1 ASSUMPTIONS}

The assumptions underlying the calculation of attainable \% LFL based on barometric slope are as follows.

1. All surface level movement which is associated with barometric pressure variations is attributable to expansion or contraction of trapped gas. As shown in Figure 8-1, it is assumed that as barometric pressure increases, the increase in pressure is transmitted to the trapped gas, and the gas is compressed, causing a decrease $(\Delta \mathrm{L})$ in the surface level of the waste. This assumption is conservative because it maximizes the amount of trapped gas and, therefore, the estimated \% LFL.

11 English units are used in calculations involving barometric slope because tank instruments measure in inches, and barometric pressure is measured in inches of mercury (in. $\mathrm{Hg}$ ). Results of calculations are shown in metric and English units. 
Figure 8-1. Increase in Barometric Pressure Compresses Gas

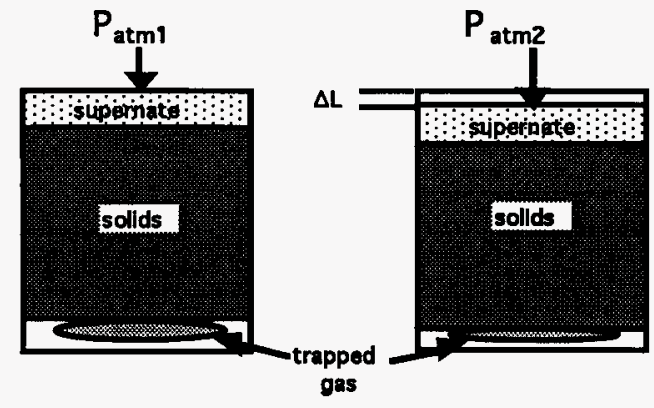

2. Boyle's Law applies. For a given mass of trapped gas at a fixed temperature, the volume of the trapped gas is inversely proportional to the pressure exerted by the gas, or $P V=k$.

3. Changes in barometric pressure are sensed immediately by the trapped gas, and trapped gas responds immediately, causing an immediate surface level change. This is not a conservative assumption, since it is known not to be universally valid. In some cases, the tank acts as a damped system, that is, there is a lag of a few hours from the time when the barometric pressure changes to the time when the surface level changes. For auto-FIC readings (taken by the Food Instrument Corporation surface level gauge and transmitted electronically to the PC-SACS database), the lag is negligible or just a few hours long. The lag can be several hours long where surface level data are manually entered into the database several hours after being taken. Not taking the lag into account can result in underestimating the slope and therefore the \% LFL by an amount ranging from a few percent for auto-FIC data to 30 to $40 \%$ for manual ENRAF data. The latter data are entered into the PC-SACS database and therefore time-stamped several hours after being taken in the field. Recognizing the consequences of using manual data, in most of his calculations of the 75\%-percentile slope (explained in the third paragraph of Section 8.0) Whitney used auto-FIC data to minimize the error. Where auto-FIC data are not used, the slope may not account for the lag and may not be conservative.

4. Surface tension effects are negligible and do not contribute to the head pressure of the gas; that is, gas bubbles are larger than 500 microns. Surface tension is calculated using the formula for surface tension $(P): P=4$ sigma/D, where surface tension is measured in pressure units, sigma is assumed to be the value for water, 0.09 pascal-meter ( 13.05 psi-micron), and $\mathrm{D}$ is bubble diameter in microns (Norton and Pederson 1994). Table 8-1 shows, using trial data for tank S-106 for gas under $101.325 \mathrm{kPa}(1 \mathrm{~atm})$ of head, the \% LFL that would be predicted for trapped bubbles of various diameters, assuming a headspace of $931.6 \mathrm{~m}^{3}\left(32,900 \mathrm{ft}^{3}\right)$. As bubble diameter, $\mathrm{D}$, increases from 5 to 1000 microns, the bubble surface tension decreases from 71.7 to $0.4 \mathrm{kPa}$. $(10.4$ to $0.05 \mathrm{psi})$, and the volume of trapped gas decreases from about $127 \mathrm{~m}^{3}$ to $93 \mathrm{~m}^{3}\left(4,500-3,300 \mathrm{ft}^{3}\right)$, while the \% LFL predicted decreases from $171 \%$ to $128 \%$. At diameters over 100 microns there is negligible effect on the volume of trapped gas and the $\%$ LFL predicted. 
Table 8-1. Effect of Surface Tension on Gas Volume and \% LFL.

\begin{tabular}{|r|c|c|c|c|c|c|c|c|c|}
\hline & \multicolumn{2}{|c|}{$\begin{array}{c}\text { Surface } \\
\text { Tension }\end{array}$} & \multicolumn{2}{c|}{$\begin{array}{c}\text { Total Press on } \\
\text { Trapped Gas }\end{array}$} & \multicolumn{2}{c|}{$\begin{array}{c}\text { Trapped } \\
\text { Gas, } \mathrm{ft}^{3}\end{array}$} & \multicolumn{2}{c|}{$\begin{array}{c}\text { Released } \\
\mathrm{H} 2, \text { scf }\end{array}$} & \\
\cline { 2 - 10 } $\mathrm{D}, \mu \mathrm{f}$ & $\mathrm{kPa}$ & $\mathrm{psi}$ & $\mathrm{kPa}$ & $\mathrm{psi}$ & $\mathrm{m}^{3}$ & $\mathrm{ft}^{3}$ & $\mathrm{~m}^{3}$ & $\mathrm{ft}^{3}$ & \% LFL \\
\hline 5 & 71.7 & 10.4 & 274.3 & 39.78 & 127.5 & 4503 & 62.3 & 2199 & 171 \\
10 & 35.9 & 5.2 & 238.4 & 34.58 & 110.8 & 3914 & 54.1 & 1912 & 150 \\
50 & 7.17 & 1.04 & 209.7 & 30.42 & 97.5 & 3443 & 47.6 & 1682 & 132 \\
100 & 3.59 & 0.52 & 206.2 & 29.90 & 95.8 & 3384 & 46.8 & 1653 & 130 \\
500 & 0.72 & 0.10 & 203.3 & 29.48 & 94.5 & 3337 & 47.6 & 1680 & 128.1 \\
1000 & 0.36 & 0.05 & 202.9 & 29.43 & 94.3 & 3331 & 46.1 & 1627 & 127.9 \\
- & 0.0 & 0.0 & 202.6 & 29.38 & 94.2 & 3325 & 46.0 & 1624 & 127.7 \\
\hline
\end{tabular}

Mathematical analysis of release profiles during mixer-pump runs in tank SY-101 indicate the bubble size is about 500 microns in waste that had been degassed only a few weeks earlier. Waste that remains undisturbed for much longer periods of time, as in SSTs, would be expected to have bubbles of at least this order of magnitude, so surface tension should not be a significant factor in estimating trapped gas volume. Therefore, this assumption appears to be appropriate.

5. The vertical position of the gas remains unchanged as the barometer rises and falls. This assumption is not necessarily true. For example, in tanks like SY-101, in which gas bubbles are thought to be attached to slurry particles, when the barometric pressure decreases, the bubbles expand and can migrate upwards, causing further bubble expansion. This further expansion amplifies the surface level rise, causing the slope (dL/dP) to increase. Using the increased slope in the calculation results in a larger calculated mass of trapped gas than the actual mass. Therefore, this assumption is conservative.

6. Gas is centered $22.5 \%$ of the wet-solids height above tank bottom, as assumed in Section 7.4.

7. Whitney's slopes represent gas expansion/contraction but not gas releases, intrusions, etc. It is anticipated that Whitney's algorithm (Whitney 1995) excludes significant surface level shifts (from transfers, instrument calibrations, etc.) but not all small single-point shifts caused by pumping or small gas releases. A more thorough evaluation of one tank decreased the magnitude of the 95-percentile slope but did not have a significant effect on the 75-percentile slope.

8. The maximum void fraction in settled solids is 0.30 . Although a higher void fraction (above 0.40 ) has been seen in laboratory experiment, this was in a graduated cylinder, which has a depth-width ratio much higher than in waste tanks. It is believed that the lower ratio in actual waste will prevent attaining such high void fractions. Moreover, in actual waste, a void fraction greater than 0.300 corresponds to gas entrapment of 3 meters for waste 10 meters deep. Slurry growth of this magnitude has not been seen in tanks.

9. The trapped gas is $97 \%$ hydrogen, as assumed in Section 7.4.

10. In an SST, 25\% of the trapped gas can be released to the headspace in an EGR over a period of several hours, days or weeks, as assumed in Section 7.4.

11. In a DST, $25 \%$ of the trapped gas can be released in an EGR, as assumed in Section 7.4.

12. The amount of ammonia released into the headspace as the result of an EGR can be as much as $22 \%$ of the volume of hydrogen. In an EGR, ammonia is released by mass transfer from 
ammonia-containing waste brought to the waste surface by the release of trapped gas. The criteria document (Hopkins 1994) specifies that the ammonia amount in the headspace is $25.9 \%$ of the gas volume released (Hopkins 1994). Based on tank SY-101, this includes some $\mathrm{NH}_{3}$ included in the trapped gas plus $\mathrm{NH}_{3}$ released by mass transfer from the waste brought to the surface in a rollover. Because the trapped gas is assumed to be $97 \% \mathrm{H}_{2}$ and $3 \%$ water vapor, the trapped gas can contain no $\mathrm{NH}_{3}$, so the fraction of $\mathrm{NH}_{3}$ released is reduced to 0.220. Although this is not specified by Hopkins (1994), it is technically appropriate.

\section{2 Calculate VOlume OF TRAPPED GaS}

Beginning with Boyle's Law ( $\mathrm{P}_{\mathrm{t}} \mathrm{V}=$ constant) for a given mass of gas in an isothermal processes, where $P_{t}$ is the total pressure on the trapped gas and $V$ is the volume of the trapped gas, differentiate as follows.

$$
\begin{aligned}
d\left(P_{t} V\right) & =0=P_{t} d V+V d P_{t} \\
\text { or, } \quad V d P_{t} & =-P_{t} d V
\end{aligned}
$$

Rearranging and substituting $\mathrm{A} x \mathrm{dL}$ for $\mathrm{dV}$ yields the equation below.

where

$$
\mathrm{V}=-\mathrm{AP}_{\mathrm{t}} \mathrm{dL} / \mathrm{dP} \mathrm{t}
$$

$A=$ area of the waste surface $\left(\pi \times 37.5^{2} \mathrm{ft}^{2}\right)^{12}$

$\mathrm{dL} / \mathrm{dP}_{\mathrm{t}}=$ slope determined by Whitney (1995)

Because the change in total pressure on the gas equals the change in barometric pressure, $\mathrm{P}_{\mathrm{b}}$,

$$
\mathrm{V}=-\mathrm{AP}_{\mathrm{t}} \mathrm{dL} / \mathrm{dP}_{\mathrm{b}}
$$

Thus, besides the slope, the only other inputs to the calculation are the area of the trapped gas (the same as the cross sectional area of the tank, $\pi \times 37.5^{2} \mathrm{ft}^{2}$ ) and the total pressure exerted on and by the gas. The total pressure on the trapped gas is the sum of barometric pressure, the head of the supernate and the head of the solids above the gas (plus any pressure exerted by surface tension). The head of waste is calculated as illustrated for a hypothetical column of water $407 \mathrm{in}$. high.

$$
\begin{aligned}
& 1 \mathrm{~g} / \mathrm{mL} \times 407 \mathrm{in} . \times 2.54^{3} \mathrm{~mL} / \mathrm{in} .^{3} \times 1 \mathrm{lb} . / 453.6 \mathrm{~g} \mathrm{x} 1 \mathrm{lb} .-\mathrm{f} / 1 \mathrm{lb} .-\mathrm{m}=14.69 \mathrm{psi} \\
& \text { or }(101.3 \mathrm{kPa})
\end{aligned}
$$

The calculation of the total pressure on the trapped gas is illustrated below for tank S-106.

$$
\begin{array}{lc}
\text { Mean barometric pressure } & 29.5 \mathrm{in} . \mathrm{Hg}(14.69 \mathrm{psi}) \\
\text { Liquid densityl3 } & 1.45 \mathrm{~g} / \mathrm{mL} \\
\text { Liquid depth (calculated) } & 1.45 \mathrm{in} . \\
\text { Solids density }{ }^{14} & 1.50 \mathrm{~g} / \mathrm{mL} \\
\text { Solids depth (assumed) } 15 & 147.17 \mathrm{in} .
\end{array}
$$

12 English units are used in calculations involving barometric slope because tank instruments measure in inches, and barometric pressure is measured in inches of mercury (in. $\mathrm{Hg}$ ). Results of calculations are shown in metric and English units.

13 If not known for a tank, assume to be $1.40 \mathrm{~g} / \mathrm{mL}$.

14 If not known for a tank, assume to be $1.80 \mathrm{~g} / \mathrm{mL}$.

15 Assumes gas is centered 30 in. above tank bottom. 


$$
\begin{aligned}
P_{t}= & P_{\text {baro }}+P_{\text {liq }}+P_{\text {solids }} \\
= & 14.69 \mathrm{psi}+\left(1.45 \mathrm{~g} / \mathrm{mL} \times 1.45 \mathrm{in} . \times 2.54^{3} \mathrm{~mL} / \mathrm{in}^{3} /\right. \\
& 453.6 \mathrm{~g} / \mathrm{lb} .)+\left(1.50 \mathrm{~g} / \mathrm{mL} \times 147.17^{\prime \prime} \times 2.54^{3} / 453.6 \mathrm{~g} / \mathrm{lb} .\right) \\
= & 14.49+0.076+7.98=22.54 \mathrm{psi}(155.4 \mathrm{kPa})
\end{aligned}
$$

The trapped gas volume is calculated using the formula $\mathrm{V}=-\mathrm{AP}_{\mathrm{t}} \mathrm{dL}_{\mathrm{dP}} \mathrm{b}$, derived on the previous page. The barometric slope for tank S-106 is $-1.44 \mathrm{in} . / \mathrm{in}$. $\mathrm{Hg}$, which bounds $75 \%$ of the range of slopes for the tank.

$$
\begin{aligned}
V & =-A P_{t} \mathrm{dL} / \mathrm{dP}_{\mathrm{b}} \\
& =-\left(\pi 37.5^{2} \mathrm{ft}^{2}\right) \times 22.54 \mathrm{psi} \times 1 \mathrm{in} \mathrm{Hg} / 0.491154 \mathrm{psi} \\
& \quad \times(-1.44 \mathrm{in} / \mathrm{in} \mathrm{Hg}) \times 1 \mathrm{ft} / 12 \mathrm{in} \\
= & 24,329 \mathrm{ft}^{3} \text { of trapped gas }\left(688.9 \mathrm{~m}^{3}\right)
\end{aligned}
$$

Check void fraction (VF):

$$
\mathrm{VF}=24,329 \mathrm{ft}^{3} \text { gas } / 63,020 \mathrm{ft}^{3} \text { waste } \times 100=39 \%
$$

Truncate to void fraction of 0.300 :

$$
V=0.300 \times 63,020 \mathrm{ft}^{3}=18,906 \mathrm{ft}^{3} \operatorname{gas}\left(1784.5 \mathrm{~m}^{3}\right)
$$

Regarding the use of the 75\%-percentile slope, see the thind paragraph in Section 8.0.

\section{3 BENCHMARK: TANK SY-103}

Fortunately, this methodology can be verified on a tank for which data recently have been obtained on gas content, that is, tank SY-103. Assuming the gas is centered at $0.762 \mathrm{~m}$ (30 in.) (22.5\% of the wet-solids depth) above the tank bottom, and using an estimated 50-percentile barometric slope of $-0.20 \mathrm{in} . / \mathrm{in}$. $\mathrm{Hg}$, the amount of gas trapped is calculated to be $118.6 \mathrm{~m}^{3}\left(4,188 \mathrm{ft}^{3}\right)$ (in situ, compressed) or $219.2 \mathrm{~m}^{3}$ (7,742 scf). This corresponds to a void space of $5.5 \%$. If the 75 percentile slope $(-0.40$ inches/in. $\mathrm{Hg})$ is used, the amount of gas and void space are doubled. The results from the 50-percentile slope are within the upper bound of estimates derived from recent void fraction measurements in the tank (See Attachment $H$ ).

\section{4 CALCULATE \% LFL}

Although it is not known whether a release in an SST can occur as a rollover, a release could occur by other means. A penetration of the waste might release a "lens" of gas contained within the waste, allowing a significant percent of the trapped gas to be released in a period of several days. Because a significant fraction of the trapped gas, beyond the fraction consisting of the lens, is expected to be dispersed throughout the waste, it seems highly unlikely that much of this dispersed gas will be released in addition to the lens. Therefore, it is assumed that $25 \%$ of the trapped gas is released. This is a preliminary estimate which needs substantiation by laboratory experimentation and modeling. The following, extracted from an Excel ${ }^{\text {m }}$ spreadsheet, illustrates the calculation of $\%$ LFL for tank S-106. 
Given for tank S-106:

Compressed volume of trapped gas $\left(\mathrm{ft}^{3}\right)$

Supernate density $(\mathrm{g} / \mathrm{mL})$

$18,906\left(535.4 \mathrm{~m}^{3}\right)$

Supernate depth (in.)

Solids density $(\mathrm{g} / \mathrm{mL})$

Solids thickness to center of trapped gas (in.) ( $m$ )

$147.17 \quad(3.738 \mathrm{~m})$

Waste temp at gas depth ( $\left.{ }^{\circ} \mathbf{F}\right)$

76.9

Waste temp at gas depth $\left({ }^{\circ} \mathrm{K}\right)$

298.1

\% H2 in solids gas (assumed) $\quad 97 \%$

Fraction of trapped solids gas releasable from solids (\%) 25\%

Calculations for tank S-106:

Supernate head $=$ supenate density $x$ supemate depth (psi) 0.076

Slurry head $=$ solids density $\mathrm{x}$ solids depth $(\mathrm{psi})$

Pressure in headspace, in psia (If calculating $\mathrm{H}_{2}$ in scf, use 14.69) 14.69

Total press. $(\mathrm{psi})=$ press. in headspace + +supernate head+solids head $\quad 22.74$

Pressure adjustment to scf $=$ total head/tank pressure in psia

Temperature adjust to scf $=298.15^{\circ} \mathrm{K} /$ waste temp at gas depth $(\mathrm{K}) \quad 1.00$

Volume of slurry gas released to headspace $(\mathrm{scf})=$ Compressed vol $x$ pressure adjustment $x$ Temperature adjustment $x$ fraction of gas released

\% $\mathrm{H}_{2}$ in headspace for tank S-106

Volume of headspace before burp $\left(\mathrm{ft}^{3}\right)$

$72,892\left(2064.1 \mathrm{~m}^{3}\right)$

Compressed vol. $x$ fraction of trapped gas released

$=$ sfc level drop $=$ headspace vol. increase caused by sfc level drop

$4,727\left(133.9 \mathrm{~m}^{3}\right)$

Vol of headspace after burp $\left(\mathrm{ft}^{3}\right)$

$\% \mathrm{H}_{2}$ in headspace $=9.15$

$(55 \mathrm{kPa})$

$(156.8 \mathrm{kPa})$

$\mathrm{NH}_{3} \%$ in headspace for tank S- 106

Assume $\mathrm{NH}_{3}$ vol = this fraction of slurry gas released $\quad 0.22$

$\mathrm{NH}_{3}$ vol in headspace $=\mathrm{NH}_{3}$ fraction $\mathrm{X}$ vol of slurry gas released $\quad 1,610$

$\% \mathrm{NH}_{3}$ in headspace $=2.07$

$\% \mathrm{LFL}=\mathrm{X}_{2} / 0.04+\mathrm{XNH}_{3} \underline{\underline{0.15 \times 100 \%}}=$

$\underline{243 \%}$

\subsection{MONTE CARLO ANALYSIS}

Each variable used in the calculation has an error band. When all the individual error bands are taken into account, they produce uncertainty in the calculated \% LFL. A Monte Carlo analysis (See Attachment F) shows the range of the calculated \% LFL.

\subsection{SURFACE LEVEL VS. 1/P}

The plot for tank S-106 in Figure 8-2 shows the surface level following inverse pressure quite closely, although surface level lags somewhat behind inverse pressure. The surface level plot lags | behind pressure because the PC-SACS database records the time the manual ENRAF readings are entered into the database, instead of the time they are taken in the field; the readings are often 
Figure 8-2. Surface Level and Inverse Pressure for Tank 241-S-106

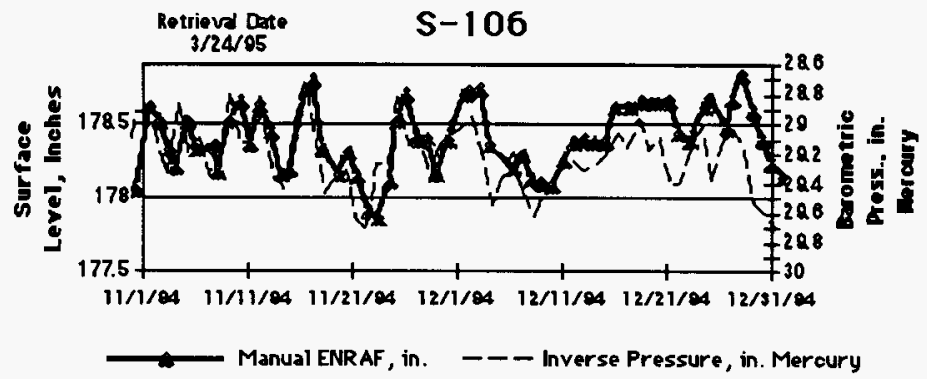

entered many hours after being taken. Not all tanks will show a correlation as good as that shown in Figure 8-2 for tank S-106. The quality of the correlation may indicate how worthwhile it is to get better surface level data for the tank.

\subsection{EFFECT OF PRESSURE DIFFERENCES}

For the analysis of barometric slope to be valid, the pressure in the tanks must closely track the barometric pressure recorded at the Hanford Meteorological Station (HMS), with regard to time and pressure. For the tracks to be close, it is required that (1) the ground-level pressure at the tank closely follow the barometric pressure recorded at the Hanford Meteorological Station, which is as much as $8 \mathrm{~km}$ ( $5 \mathrm{mi}$.) from the tank farthest from the station, and (2) the pressure inside the tank closely track that at ground level.

\subsubsection{Hanford Meteorological Station Pressure vs. Pressure at a Tank}

Regarding the first requirement, there is a slight difference between the pressure at the HMS and at a tank. As a front passes over the HMS in West Area, the HMS pressure changes. It can take as much as 10-12 minutes for the front and its pressure change to reach tanks in East Area (see mail message in Attachment $\mathbf{L}$ ). Thus, depending on the location of a tank, there could be a delay of a few minutes between a pressure change occurring at the HMS and at the tank. One of the highest rates of pressure change in recent decades was recorded in 1958. An estimate of the worst-case pressure difference between the HMS and the tank can be made from this rate, $0.091 \mathrm{in}$. $\mathrm{Hg} / \mathrm{h}$ $(0.31 \mathrm{kPa})$, and the fact that it takes $10-12$ minutes for a pressure change to move from the HMS to the tank farthest away (see Attachment L).

$$
0.091 \text { in. } \mathrm{Hg} / \mathrm{h} \times 1 \mathrm{~h} / 60 \mathrm{~min} . \times 12 \mathrm{~min}=0.018 \text { in. } \mathrm{Hg}(0.31 \mathrm{kPa})
$$

This is an extreme case; seldom is a front this severe. Normally the difference in pressure between the HMS and the farthest tank is from 0.0 to $0.01 \mathrm{in.} \mathrm{Hg}(0.03 \mathrm{kPa})$. In general, this pressure difference can make a difference of 0 to $5 \%$ in the volume of gas predicted based on barometric slope. This difference is minor compared to the uncertainty that can result from the time lags discussed in Section 8.6.

An additional but minor pressure difference is caused by the elevation difference between the HMS and a given tank. At a tank $100 \mathrm{ft}$. $(30.5 \mathrm{~m})$ below the HMS, the pressure is about $0.10 \mathrm{in}$. $\mathrm{Hg}$ 
$(0.31 \mathrm{kPa})$ higher. If the waste surface level is $40 \mathrm{ft}$. $(12.2 \mathrm{~m})$ below ground level, the pressure is $0.04 \mathrm{in} . \mathrm{Hg}(0.0014 \mathrm{kPa})$ higher than at ground level. Thus, the pressure difference between the HMS barometer and the waste surface is 0.14 in. $\mathrm{Hg}(0.47 \mathrm{kPa})$. Attachment $\mathrm{L}$ contains a comparison of the plots of HMS pressure and the pressure recorded in 200 East and 200 West tank farm areas. It shows that the pressure at the tanks is higher than that at HMS. At least part of this pressure difference exists because the barometers in the farms are lower in elevation than the HMS barometer. Such a difference has no effect on the barometric slope, since the slope depends not on pressure magnitude but on pressure variations. On the other hand, the difference does have a minor effect on the total pressure on the gas, $\mathbf{P}_{t}$, and the predicted gas volume; the effect is only about $0.5 \%$. This can be determined from the equations below for a hypothetical volume of trapped gas calculated to be under a total pressure of $25.00 \mathrm{psi}$, based on HMS pressure. The pressure would be $0.14 \mathrm{in} . \mathrm{Hg}(0.47 \mathrm{kPa})$ higher at the waste surface. The volume $\mathrm{V}_{\mathrm{H}}$ is the gas volume calculated based on pressure at the $\mathrm{HMS}$, and $\mathrm{V}_{\mathrm{C}}$ is the volume calculated based on pressure at the waste surface, that is, the pressure corrected for the difference in elevation.

$$
\begin{aligned}
& \mathrm{V}=-\mathrm{A} \mathrm{P}_{\mathrm{t}} \mathrm{dL} / \mathrm{dP} \mathrm{b} \\
& \mathrm{V}_{\mathrm{H}}=-\mathrm{A} \times 25.00 \mathrm{psi} \times \mathrm{dL} / \mathrm{dP}_{\mathrm{b}} \\
& \mathrm{V}_{\mathrm{C}}=-\mathrm{A} \times 25.14 \mathrm{psi} \times \mathrm{dL} / \mathrm{dP}_{\mathrm{b}}
\end{aligned}
$$

The volume $\mathrm{V}_{\mathrm{C}}$ calculated with the corrected pressure is greater than $\mathrm{V}_{\mathrm{H}}$ by the fraction $0.14 / 25.00$, or 0.006 .

\subsubsection{Ground-Level vs. Waste-Level Pressure}

The second requirement for the pressure in the tanks to closely track the barometric pressure recorded at the HMS is that the pressure inside the tank closely track the pressure at tank ground level. For passively vented SSTs, the pressure in the tank does closely track the pressure outside the tank. That is, the rate of air flow required to pass through the breather filter is so low that the changes in barometric pressure are, for all practical purposes, transmitted instantly to the inside of the tank. This can be seen even in the case of the very steep 6-hour pressure rise on November 4 , 1958. On that date, the rate of rise was $0.307 \mathrm{kPa} / \mathrm{h}$. $(0.0907 \mathrm{in} . \mathrm{Hg} / \mathrm{h}$.). This was an increase of about $0.3 \%$ of the absolute pressure per hour. For a tank with a large headspace, for example $2,500 \mathrm{~m}^{3}\left(88,287 \mathrm{ft}^{3}\right)$, in an hour the increase would cause the tank to inhale $0.3 \%$ of its headspace volume, $78 \mathrm{~m}^{3}\left(274 \mathrm{ft}^{3}\right)$. Over a 6 -hour period, the flow rate into the tank would be $0.22 \mathrm{~m}^{3} / \mathrm{min}(7.4 \mathrm{cfm})$. This is an insignificant flow rate compared to the flow capacity of the HEPA filter, so that, even for this extreme rate of pressure change, barometric pressure changes are transmitted immediately to the inside of a passively tank.

For actively vented SSTs and DSTs, consider DST SY-101 as an example. Attachment L includes a plot of the barometric pressure and headspace (dome) vacuum for the tank during December 1995. The barometric pressure, the units of which are on the left-hand $Y$ axis, varies from about 13.82 to 14.63 psia (95.29 to 100.9 ). The in-tank pressure (dome pressure) is shown for two locations, riser 11B and riser 17B. These pressures, the units of which are on the right-hand $\mathrm{Y}$ axis, average about -2 in. water gauge (w.g.) $(-0.5 \mathrm{kPa}) .^{16}$

How closely does the pressure exerted on the waste surface, $\mathrm{P}_{\text {headspace, }}$ track the barometric pressure? That is, how close is $\Delta \mathrm{P}_{\text {headspace }}$ to $\Delta \mathrm{P}_{\text {barometric? }}$ ? This is easily determined by

16 Note that the scale on the right-hand margin is expanded to four times that of the left-hand margin. That is, the range of the right-hand axis is $5 \mathrm{in}$. w.g., $0.18 \mathrm{psi}(1.2 \mathrm{kPa})$, and $0.2 \mathrm{psi}$ is $\sim 1 / 4$ the $0.8 \mathrm{psi}(5.5 \mathrm{kPa})$ range shown on the left margin. 
examining the plot of these pressures for SY-101 (again, see Attachment L). The pressure exerted on the waste surface, $P_{\text {headspace, }}$ is the barometric pressure plus the vacuum resulting from the exhaust. For the barometric pressure peak on December $7, \mathrm{P}_{\text {headspace }}$ is calculated as follows:

$$
\begin{aligned}
& P_{\text {headspace }}=P_{\text {barometric }}+P_{\text {vacuum }} \\
& P_{\text {vacuum }}=-2 \text { in. w.g. }=-0.072 \mathrm{psi}(0.50 \mathrm{kPa}) \\
& P_{\text {headspace }}=14.63 \mathrm{psi}-0.07 \mathrm{psi}=14.56 \mathrm{psi}(100.4 \mathrm{kPa})
\end{aligned}
$$

For the pressure low on December 12, the headspace pressure is calculated as follows:

$$
\begin{aligned}
P_{\text {headspace }} & =P_{\text {barometric }}+P_{\text {vacuum }} \\
P_{\text {vacuum }} & =-1.8 \text { to }-3.0 \text { in. w.g. } \\
& =-0.07 \text { to }-0.11 \mathrm{psi} \text { ( } 0.50 \text { to } 0.76 \mathrm{kPa}) \\
P_{\text {headspace }} & =13.82 \mathrm{psi}-(0.07 \text { to } 0.11 \mathrm{psi}) \\
& =13.71 \text { to } 13.75 \mathrm{psi}(94.5 \text { to } 94.8 \mathrm{kPa})
\end{aligned}
$$

Between the above high and low, $\Delta \mathrm{P}_{\text {barometric }}$ is $0.81 \mathrm{psi}$, as calculated below.

$$
\begin{aligned}
\Delta \mathrm{P}_{\text {barometric }} & =14.63-13.82 \\
& =0.81 \mathrm{psi}=1.65 \mathrm{in} . \mathrm{Hg}=22.4 \mathrm{in} \text {. w.g. }=5.6 \mathrm{kPa}
\end{aligned}
$$

For the same interval, $\Delta \mathrm{P}_{\text {headspace }}$ is about 0.81 to $0.85 \mathrm{psi}(5.6$ to $5.9 \mathrm{kPa}$ ).

$$
\begin{aligned}
\Delta \mathrm{P}_{\text {headspace }} & =14.56 \mathrm{psi}-(13.71 \text { to } 13.75 \mathrm{psi}) \\
& =0.81 \text { to } 0.85 \mathrm{psi}(5.6 \text { to } 5.9 \mathrm{kPa})
\end{aligned}
$$

Thus, $\mathbf{P}_{\text {headspace }}$ tracks $\mathbf{P}_{\text {barometric }}$ within about $5 \%$. In tanks with lower exhaust rates, tracking is expected to be better. For the few tanks with higher exhaust rates, tracking may be somewhat worse. 
WHC-SD-WM-TI-724, Rev. 1

This page intentionally left blank. 


\subsection{O'THER POTENTIAL FLAMMABILITY HAZARDS}

Section 6.0 of Attachment B requires evaluation for other potential hazards, such as flammable gas flowing into a tank through a cascade line from an adjacent tank. If there is a potential hazard that could cause a tank to contain a mixture exceeding any of the criteria, the tank should be considered to have failed that criterion. Thus, if a flammable gas mixture in a subsystem (such as a vent header) can attain a criterion limit and has credible potential to cause a serious release, this is a basis for considering the tank to have failed the criterion. As of the publication date of this document, none of the flammable gas evaluations done according to this document have addressed the requirement of Section 6.0 of Attachment B. Moreover, the evaluations have not addressed the possibility that gas might flow through cascade lines from a flammable gas tank to an adjoining tank.

Any nuclear waste tank containing moisture generates flammable gas. Therefore, any operation which disturbs the waste has the potential to release some amount of flammable gas. Operations such as mixing or retrieval must be evaluated to determine whether they present a credible hazard of a serious release.

This methodology is focused on conservatively evaluating the possibility of flammable gas exceeding flammability criteria in a tank's headspace. The fact that a tank does not exceed the criteria does not mean the tank does not contain trapped gas. It is anticipated that every tank containing solids generates and traps some amount of gas. 
WHC-SD-WM-TI-724, Rev. 1

This page intentionally left blank. 


\subsection{IMPROVEMENTS NEEDED}

Reviewers have identified various improvements needed on this methodology to eliminate excess conservatism and reduce data scatter. Others have suggested that the methodology be changed to a probabilistic evaluation. Finally, there is a need to verify the methodology's conservatism in two areas. This section discusses several improvements, as well as approaches for achieving them.

\subsection{EXCESS CONSERVATISMS}

For some of the parameters used to calculate \% LFL, the values used in the deterministic calculations contain excess conservatism, as do some of the probabilistic distributions used in the Monte Carlo analysis. Excess conservatism was included in initial assumption to compensate for the lack of knowledge about the parameters. As knowledge improves, the excess can be reduced. Several of these parameters are listed below, with possible or in-progress efforts to improve knowledge.

\subsubsection{Barometric Slope Method}

1. Tank Area: The trapped gas volume is calculated by the formula $V=-$ Area $x$ porosity $x$ slope. It is assumed that the cross-sectional area is that of the entire tank. However, for gas trapped in solids, this might not be the case, since cooling around the tank perimeter would tend to increase precipitation and prohibit gas from being trapped near the perimeter, reducing the effective tank area. An effort could be made to estimate the reduction.

2. Hydraulic effect. In tanks in which the FIC gauge is in a salt well or the ILL is measured in a liquid observation well surrounded by supernate, there might be a hydraulic effect which greatly magnifies the supernate's response to barometer changes. That is, when barometric pressure falls, expanding trapped gas may quickly raise the supemate in the well where the FIC or neutron probe is, but only slowly raise the liquid in the surrounding solids. This would cause the tank to appear to contain more trapped gas than it actually does. If this were the case, the level reading should respond more quickly to rapid than slow pressure changes. Tank surface level plots could be examined to detect this behavior. In such cases, it seems that the slope during slower pressure changes would be a better predictor of trapped gas volume.

\subsubsection{Surface Level Rise Method}

1. Evaporation. The greater the amount of evaporation calculated, the greater the surface level rise calculated. The evaporation calculated is a function of the aqueous vapor pressure of the waste and the air flow through the headspace, among other factors. The calculation assumes the air leaving the tank is at $100 \%$ relative humidity. This is based on the conservative assumptions that 1) the waste has the aqueous vapor pressure of $100 \%$ water, and 2) water vapor in the headspace is at that pressure, that is, is at equilibrium with the water in the waste. However, in reality the waste's aqueous vapor pressure is greatly reduced by its high salt content, and the system is not at equilibrium. As an initial effort to reduce excess conservatism in this area, calculated evaporation can be reduced by conservatively estimating the effect these factors have on the relative humidity of the exhausted air. Historical psychrometric records might allow some reduction in calculated evaporation; however; data in these records tend to be of poor quality. 
The air flow through a tank is estimated based on the convective flow through tank A-101. If the flow could be accurately measured (for example, with flow instruments, or with analytical instruments which measure the rate of escape of a tracer gas), the calculated evaporation might be reduced for some tanks.

Reduction can also be achieved by thermal hydraulic modeling. However, modeling often assumes that cascade lines between tanks allow air flow between tanks. In reality, these lines may be partly or completely plugged. Models could be benchmarked against current tank conditions by careful measurements of the current flow rate and absolute humidity of air entering and leaving individual tanks.

2. Condensation. The surface level can rise slightly when outside air enters a tank in summer and humidity condenses on a cold riser or salt well screen, etc., then drains down into the tank. Conservative calculation of the amount of condensation might reduce the amount of surface level rise attributed to gas in some tanks. Similarly, condensation can occur from moist air leaving a tank, making the evaporation less than calculated. If the amount of such condensation could be established, it could reduce the amount of evaporation calculated.

3. Adjustments to Surface Level Rise. Section 7.2 identifies adjustments to the surface level. An effort could be made to identify factors which legitimately minimize losses which must be added to surface level, such as factors which overestimate supernate volume pumped from a tank. For example, water added to prime saltwell pumps is not shown as having been added to the tank, although the water is included in waste pumped from the tank. In a few tanks, this might result in a significant increase in the waste's surface level rise. Also, records should be searched for provable additions to tanks, such as draining a condenser pit into a tank.

\subsubsection{Barometric Slope and Surface Level Rise Methods}

1. Eraction of trapped gas released. PNNL is working to determine the fraction of trapped gas that can be released from various types of waste under normal and earthquake conditions. If the release is predicted to occur over a period of several hours, days or weeks, the calculation of the \% LFL should compensate for the gas exhausted from the headspace before the release is complete.

2. Fraction of trapped gas which is flammable. Use of the retained-gas sampler has begun to determine the composition of trapped gases in tank waste. Efforts are also underway to use the Toxic Vapor Program's analysis of headspace gases (referred to in the first paragraph of Section 4.0) to partly determine the composition of trapped gas.

3. Fraction of $\mathrm{NH}_{3}$ released by mass transport. The amount of $\mathrm{NH}_{3}$ released in an EGR is assumed to be 0.22 times the amount of trapped gas released. In reality, the possible concentration of $\mathrm{NH}_{3}$ in the headspace may be limited by other factors. $\mathfrak{D}$. A. Reynolds has begun to work on this.

4. Center of trapped gas. The center of trapped gas is assumed to be deep in the waste. The methodology makes no adjustment for gas trapped higher in the tank, such as in a floating crust. In tanks in which gas is known to be centered higher in the waste, the location should be adjusted upward. The assumed location is based on tank SY-103, which periodically releases gas from the top of the wet solids. A release lowers the center of the remaining trapped gas. Thus the center of trapped gas in a tank which undergoes periodic releases should be lower than in tanks which do not have significant periodic releases. In the latter tanks, the center of gas might be significantly higher. The effect of this on the amount of calculated trapped gas should be considered. 


\subsection{EXCESSIVE DATA SCATTER}

For some of the parameters used, the data scatter is very wide. Improving the instrumentation used to measure surface level would greatly reduce data scatter in several parameters. Several of these parameters are listed below, with possible or in-progress efforts to improve data quality.

\subsubsection{Barometric Slope Method}

1. Barometric slope. Very negative slope or a wide range on the slope is a result of poor surface level/ILL data or too wide a "shift criterion" in the algorithm defining the intervals for which a slope is calculated. Data can be poor because of an imprecise gauge; infrequent readings; or manual readings being entered into the SACS database with a time stamp several hours after they were actually taken. These problems can be solved by installing ENRAF gauges on tanks which have none and connecting them to the Tank Monitoring and Control System (TMACS) for automatic data capture. Once auto-ENRAF readings are available, the best slope data can be obtained from readings taken during a continuous pressure increase (or decrease) occurring over a period of several days. For ILL readings, data will be improved by taking IL readings with the improved equipment recently procured. Data can also be poor because the level change either lags behind or advances ahead of the barometric change (depending on the direction of the barometric change). This might be caused by waste shear strength or other physical factors, such as the hydraulic effect discussed in Section 10.1.1. This could be investigated by physical experiments or modeling.

As described in Attachment L, minor data scatter results from differences between pressure in the tank and the pressure in actively exhausted tanks. A decrease of perhaps 5 to $15 \%$ in data range might be obtained for actively exhausted tanks by using in-tank pressure instead of ambient barometric pressure to determine slope.

Whitney (1995) used an algorithm to divide surface level data into intervals. One of the algorithm's determiners of interval length was the presence of a sudden surface level shift of a few tenths of an inch. If the "shift criterion" in the algorithm was too wide, an interval might include a minor level variation from a minor gas release, causing data scatter. This problem could be reduced by manual examination of the tank's level plot to detect such intervals, then breaking each such interval into two or more intervals.

2. ENRAF "stickiness." Some ENRAFs show "stickiness." For example, at least one ENRAF makes a daily "step change" at about 9 AM. This limits the usefulness of the data. For tanks for which better data are needed, this problem should be addressed.

3. Location of surface level measurement. In tanks with an irregular waste surface it is important to know where the surface level plummet contacts the surface. In the absence of information to the contrary, it is assumed that the level at which the plummet contacts the waste is the average waste height. However, this is not true if the plummet is in a hole. In tanks for which there are no recent photographs or videos, there may be considerable uncertainty about where the plummet contacts the waste. Tanks for which this information is critical should be identified and new photographs or videos made.

\subsubsection{Barometric Slope and Surface Level Rise Method}

1. Void fraction. The calculated void fraction is used to calculate volume of gas released. The methodology assumes that the void fraction in wet solids could reach $30 \%$. However, the void fraction instrument has not found void fractions above about $15 \%$. The difference between 
observed and calculated void fraction is probably the result of a wide error band in the slope, where the error band results from poor data quality. Reducing the scatter as described in Section 10.2.1 would reduce the calculated void fraction and the resulting \% LFL. In addition, the calculated void fraction can be reduced in two ways.

First, use instrumentation to determine the void fraction of the waste. One such instrument is the void fraction instrument, which is already used in double-shell tanks. Another possibility is a pressure gauge. A $5-\mathrm{m}(9.84-\mathrm{ft}$.) depth of solids with a density of $1.8 \mathrm{~g} / \mathrm{mL}$ would exert a pressure of $53.0 \mathrm{kPa}$ (7.68 psi) on trapped gas. A $30 \%$ void fraction would reduce the effective density by $30 \%$, to $1.26 \mathrm{~g} / \mathrm{mL}$, so a 5 -m depth of waste would exert a pressure of $37.1 \mathrm{kPa}$ (5.38 psi). Thus, if the density of degassed solids in a particular tank were known from sample analysis, one could calculate the pressure which would be exerted at a particular depth by waste with $0 \%$ void. By inserting a pressure gauge into the tank, it would be possible to determine the actual pressure and thus the actual \% void of the waste above the pressure gage. If pressure is the same at a particular depth within the waste, the \% void should be an average for the solids across the entire tank. It may be possible to determine whether this approach is valid by examining data obtained from the Velocity-Density-Temperature Tree (VDTT) inserted earlier into tank SY-101.

Second, consider whether it is physically possible for a tank to contain $30 \%$ void fraction. For example, in solids $10 \mathrm{~m}$ deep, $3 \mathrm{~m}$ would be gas. That is, the solids would have experienced $3 \mathrm{~m}$ of gas growth. Is that possibility consistent with the waste's behavior and history? If not, how much growth is consistent? Or, if the methodology calculates that the tank already had a $30 \%$ void fraction when it was salt-well pumped in the $1980 \mathrm{~s}$, wouldn't sluicing the salt well into place have caused a significant volume of gas to be released (with a corresponding level drop) even before pumping began? If no decrease occurred, what is the maximum credible void fraction?

In any case, once the void fraction is calculated, it may be appropriate to iterate the calculation to determine whether and how much the void reduces the pressure on the trapped gas, then to recalculate the volume of trapped gas.

2. Headspace volume. The irregular surface of the waste causes uncertainty in estimating surface level and headspace volume. Because the headspace volume directly affects the calculated \% LFL, it may be worthwhile in a few tanks with very irregular surfaces, to use photogrametry to map the surface level and accurately determine the headspace volume.

\subsection{SWITCH TO PROBABILISTIC CRITERIA}

In the evaluations published by Hodgson et al. (1996), calculations used to evaluate a tank were deterministic. The deterministic values calculated were generally at the $97-99 \%$ confidence level, as calculated using the evaluation team's conservative Monte Carlo methods. Table 10-1 shows

Table 10-1. Confidence Level vs. Standard Deviation Above Mean

\begin{tabular}{|c|c|}
\hline Confidence Level & $\begin{array}{c}\text { Standard Deviations } \\
\text { Above Mean }\end{array}$ \\
\hline 95.0 & 1.6 \\
\hline 97.0 & 1.9 \\
\hline 98.0 & 2.0 \\
\hline 99.0 & 2.3 \\
\hline 99.5 & 2.6 \\
\hline 99.9 & 3.0 \\
\hline 99.95 & 3.3 \\
\hline
\end{tabular}


for individual confidence levels the corresponding number of standard deviations above the mean. This indicates that there is some probability that the post-EGR flammable gas concentration might be higher than the deterministic value calculated by the evaluation team. For this reason, future evaluations might better be done on a probabilistic basis.

It has been suggested that the criteria for FGWL tanks be redefined so that a tank would fail the criteria if there were a probability higher than $10^{-4} / \mathrm{yr}$. that the tank could attain $100 \%$ of the LFL. If this change were made, it would be necessary to increase the number of Monte Carlo trials to define the upper range of the \% LFL distribution.

\subsection{VERIFICATION OF CONSERVATISM}

There are two nonconservative assumptions which should be further examined to determined whether they were appropriate.

First, the "quick screen" (described in Section 6.0), which evaluates a tank's post-EGR flammable gas concentration, assumes that if a tank passes the quick screen, it also contains too little waste to generate enough flammable gas to fail the steady-state criterion. Although this assumption appears well founded, it should be verified by examining headspace gas sampling of tanks which passed the quick screen.

Second, in some tanks the ILL was used to estimate surface level rise. In general, the period for these evaluations began in the mid 1980s. A handful of these evaluations may not estimate the amount of gas already trapped in the waste when the evaluation period began. The accuracy of the surface level rise could be verified by using the improved neutron probe (discussed in Section 10.2.1) to determine the tank's gas content using the barometric slope. 
WHC-SD-WM-TT-724, Rev. 1

This page intentionally left blank. 


\subsection{REFERENCES}

Allemann, R. T, 1995, A Discussion of Some Mechanisms of Sudden Gas Release from SingleShell Waste Tanks at Hanford, PNL-WTS-101095, Rev. 0, Pacific Northwest Laboratory, Richland, Washington.

Anantatmula, R. P., Mike Danielson (PNNL), E. B. Schweck (WHC), 1994, Characterization of the Corrosion Behavior of the Carbon Steel Liner in Hanford Site Single-Shell Tanks, WHCEP-0772, Rev. 0, Westinghouse Hanford Company, Richland, Washington.

Colson, J. B. and P. D. Whitney, 1995, Analytical Method for Estimating Pumpable Liquid Remaining in Hanford Single-Shell Waste Storage Tanks, Pacific Northwest Laboratory, Richland, Washington.

Crippen, M. D., 1993, Barometric Pressure Variations, WHC-EP-0651, Rev. 0, Westinghouse Hanford Company, Richland, Washington.

Graves, R. D., 1994, Topical Report on Flammable Gases in Non-Burping Waste Tanks, WHCSD-WM-SARR-015, Rev. 0, Westinghouse Hanford Company, Richland, Washington.

Hanlon, B. M., 1995, Tank Farm Surveillance and Waste Status Summary Report for June 1995, WHC-EP-0182-87, Westinghouse Hanford Company, Richland, Washington.

Heard, F. J., 1995,Waste Tank 241-SY-101 Dome Air Space and Ventilation System Response to a Flammable Gas Plume Burn, WHC-SD-WM-ER-515, Rev. 0, Westinghouse Hanford Company, Richland, Washington.

Hodgson, K. M., 1996, Evaluation of Hanford Tanks for Trapped Gas, WHC-SD-MW-ER-526, Rev. 1, Westinghouse Hanford Company, Richland, Washington.

Hopkins, J. D., 1994, Criteria for Flammable Gas Watch List Tanks, WHC-EP-0702, Rev. 0, Westinghouse Hanford Company, Richland, Washington.

Juran, J. M., Editor in Chief, 1988, Juran's Quality Control Manual, McGraw-Hill, Inc., New York, New York.

Joncus, S. J., 1982, Change Control Procedure and Reference for Document RHO-RE-SR-14, SD-RE-CMP-001, Rockwell Hanford Operations, Richland, Washington.

Norton, J. D., and L. R. Pederson, 1994, Ammonia in Simulated Hanford Double-Shell Tank Waste: Solubility and Effects on Surface Tension, PNL-10173, Pacific Northwest Laboratory, Richland, Washington.

Shepard, C. L., C. W. Stewart, J. M. Alzheimer, G. Terrones, G. Chen, and N. E. Wilkins, 1995, In Situ Determination of Rheological Properties and Void Fraction: Hanford Waste Tank 241-SY-103, PNL-10865, Pacific Northwest National Laboratory, Richland, Washington.

Thurgood, M. J. and Ogden, D. M., 1995, Revised Tank Level Method for Flammable Gas Evaluation (internal memorandum 7D410-95-DMO-010 to W. B. Barton, December 12), Westinghouse Hanford Company, Richland, Washington. 
Toth, J. J., P. G. Heasler, M. E. Lerchen, J. G. Hill, and P. D. Whitney, 1995, Analysis of Organic Carbon and Moisture in Hanford Single-Shell Tank Waste, PNL-10360, Pacific Northwest Laboratory, Richland, Washington.

Welty, R. I., 1988, Waste Storage Tank and Leak Detection Criteria, SD-WM-TI-356, Westinghouse Hanford Company, Richland, Washington.

WHC, 1995a, Operating Specification for Watch List Tanks, TO-OSD-T-151-000, Rev. B-15, Westinghouse Hanford Company, Richland, Washington.

WHC, 1995b, Operating Specifications for Aging-Waste Operations in 241-AY and 241-AZ, TO-OSD-T-151-00017, Rev. D-7, Westinghouse Hanford Company, Richland, Washington.

WHC, 1995c, OperatingSpecifications for Single-Shell Waste Storage Tanks, TO-OSD-T-15100013, Rev. D-9, Westinghouse Hanford Company, Richland, Washington.

WHC, 1995d, OperatingSpecifications for the 24I-AN, -AP, -AW, -AY, -AZ, and SY Tank Farms, TO-OSD-T-151-00007, Rev. H-16, Westinghouse Hanford Company, Richland, Washington.

Whitney, P. D., 1995, Screening the Hanford Tanks for Trapped Gas, PNL-10821, Pacific Northwest Laboratory, Richland, Washington. 


\subsection{ACKNOWLEDGEMENTS}

This description of the method for evaluating tanks for potential flammable gas entrapment has been improved by the input of many individuals. Their contributions are gratefully acknowledged. Those with whom the evaluation team has most frequently interacted in recent weeks are named below. There are others who have indirectly contributed to this document, but time prevents listing them all. Their contributions are nonetheless greatly appreciated.

Barker, S. A. - contributed greatly to standardizing the evaluation process: started with a rudimentary spreadsheet incorporating basic calculations and significantly upgraded it to include evaluation logic, look-up tables, greatly improved formatting and handling of Monte Carlo inputs. For Revision 1, wrote the DSI in Attachment C providing background for the calculation of liquid evaporation from tank waste, and greatly improved the spreadsheet calculations of evaporation.

Evaluation team members: R. P. Anantatmula, S. A. Barker, K. D. Fowler, K. M. Hodgson, D. C. Hedengren, E. I. Husa, J. A. Lechelt, D. A. Reynolds, F. M. Simmons, R. E. Stout, R. T. Winward, and G. W. Reddick - As a group, significantly improved the quality of this document by challenging details of the evaluation methodology and/or by commenting on the document draft.

Hodgson, K. M. - Team leader of the evaluation team; provided considerable help in clarifiying relationships between factors in the evaluation.

Reynolds, D. A. - provided frequent sanity tests between the conceptual model of tanks and the real world in waste tanks; identified significant inconsistencies between the draft of this document and how the evaluation was actually performed.

Review team members: D. Ogden, T. R. Beaver, P. U. Peistrup, F. A. Schmittroth, M. J. Thurgood (John Marvin Inc.), A. Nuels (Los Alamos National Laboratory) - Provided a thorough review of the methodology and recommended changes to improve it. Special thanks to Marv Thurgood and Don Ogden, who provided material in Attachment $\mathrm{K}$ regarding the adjustment for evaporation in the surface-level rise method.

Scientists at Pacific Northwest National Laboratory who interacted with the evaluation team to provide input used in this document: R. T. Allemann, M. E. Brewster, P. A. Gauglitz, J. D. Hudson and C. W. Stewart - Helped to define and begin elucidating the mechanisms by which gas can be released from tank waste. Stewart also provided the differentiation in Section 8.2.

Whitney, P. D., Pacific Northwest National Laboratory - Interacted continually with the evaluation team to provide histograms of barometric slopes and advice on improving the logic of applying the slopes to tanks. 
WHC-SD-WM-TI-724, Rev. 1

This page intentionally left blank 
WHC-SD-WM-TI-724, Rev. 1

\section{ATTACHMENT A}

\section{TANK DATA REQUIREMENTS}


This page intentionally left blank 
This attachment defines the data requirements for evaluating tanks against the Flammable Gas Watch List (FGWL) criteria, and it provides a form for recording data about a tank and its waste.

The following information about the tank's construction should be reported for each tank evaluated. Items, dates and references are given for tank S-106.

\section{Tank S-106}

Deserintion
Constructed
Placed in service
Inactivated
Leak Status

\section{Data.}

1950 to 51

1953

1976

Sound
Reference

Brevick et al. 1994

Brevick et al. 1994

Brevick et al. 1994

Hanlon 1995

Table A-1 lists the data needed to evaluate tanks against the FGWL criteria. The evaluator must record data on this form and sign the final file copy to certify the data and their sources.

Alternately, the evaluator may sign the final file copy of the data section of the spreadsheet. The references listed below contain much of the data needed.

Brager, H. R. 1993, Summary of Information of Flammable Gas Watch List Tanks, WHC-SDWM-TI-0132, Westinghouse Hanford Company, Richland, Washington.

Brevick, C. H., L. A. Gaddis, and W. W. Pickett, 1994, Historical Tank Content Estimate for the Southwest Quadrant of the Hanford 200 West Areas, WHC-SD-WM-ER-352, Westinghouse Hanford Company, Richland, Washington.

Graves, R. D., 1994, Topical Report on Flammable Gases in Non-Burping Waste Tanks, WHCSD-WM-SARR-015, Rev. 0, Westinghouse Hanford Company, Richland, Washington.

Hanlon, B. M., 1995, Tank Farm Surveillance and Waste Status Summary Report for June 1995, WHC-EP-0182-87, Westinghouse Hanford Company, Richland, Washington.

Joncus, S. J., 1982, Change Control Procedure and Reference for Document RHO-RE-SR-14, SD-RE-CMP-001, Rockwell Hanford Operations, Richland, Washington. (RHO-RE-SR-14 is titled Waste Status Summary.)

Leach, C. E. and S. M. Stahl, 1993, Hanford Site Tank Farm Facilities Interim Safety Basis, WHC-SD-WM-ISB-001, Rev 0, Westinghouse Hanford Company, Richland, Washington.

Swaney, S. L., 1994, Single-Shell Tank Stabilization Record, SD-RE-TI-178, Rev 4, Westinghouse Hanford Company, Richland, Washington.

Toth, J. J., C. E. Willingham, P. G. Heasler, P. D. Whitney, 1995, Analysis of Organic Carbon and Moisture in Hanford Single-Shell Tank Waste, PNL-10360, Pacific Northwest Laboratory, Richland, Washington.

WHC, 1994, Radionuclide and Chemical Inventories for the Single-Shell Tanks, WHC-SD-WMTI-565, Rev 2, Westinghouse Hanford Company, Richland, Washington. 
Table A.1. Tank Data Collection Form (2 sheets).

\begin{tabular}{|c|c|c|c|c|}
\hline Line & Item Description & Units & Data & Data Source/Comments \\
\hline 1 & Tank No. & & & \\
\hline 2 & Calculation date (Spreadhseet will automatically enter.) & & & Hanlon 1995 \\
\hline 3 & Total waste volume & gal & & Hanlon 1995 \\
\hline 4 & Total solids volume (sludge + saltcake), including gas & $\overline{\mathrm{gal}}$ & & Hanlon 1995 \\
\hline$\overline{5}$ & Supernate volume & gal & & Hanlon 1995 \\
\hline 6 & Volume of interstitial liquid & gal & & \\
\hline 7 & Volume of sludge & gal & & Hanlon 1995 \\
\hline 8 & Current solid surface level height (Reading SLC) & in. & & \\
\hline 9 & Original solid surface level height (Reading SLH) & in. & & \\
\hline 10 & as of this date: & date & & \\
\hline 11 & Current liquid level height (Reading LLC) & in. & & \\
\hline 12 & Original liquid level height (Reading LLH) & in. & & \\
\hline 13 & as of this date: & date & & \\
\hline 14 & $\begin{array}{l}\text { Engineer selects source of solids volume (Hanlon, SLC } \\
\text { or LLC) }\end{array}$ & & & \\
\hline 15 & $\begin{array}{l}\text { Engineer selects source of interstitial liquid volume } \\
\text { (Hanlon, SLC or LLC) }\end{array}$ & & & \\
\hline 16 & $\begin{array}{l}\text { Engineer selects source of supernate volume (Hanlon, } \\
\text { SLC or LLC) }\end{array}$ & & & \\
\hline 17 & Supernate density. If unknown, enter 1.40. & $\mathrm{~g} / \mathrm{mL}$ & & \\
\hline 18 & Solids density. If unknown, enter 1.80 & $\mathrm{~g} / \mathrm{mL}$ & & \\
\hline 19 & $\begin{array}{l}\text { Porosity (liquid fraction) in solids, by assay. If } \\
\text { unknown, enter } 0.501 \text {. }\end{array}$ & & & \\
\hline 20 & Porosity (sludge). If unknown, enter 0.16 & & & \\
\hline 21 & $\begin{array}{l}\text { Average gas location: fraction of wet solids from } \\
\text { bottom center. If unknown, enter }=0.225 \text {. }\end{array}$ & & & \\
\hline 22 & Estimated maximum evaporation & in. & & \\
\hline 23 & $\mathrm{~g}$ TOC/L waste (wet) & $\mathrm{g}^{\mathrm{I}(0 \mathrm{C} / \mathrm{L} \text { (wet) }}$ & & \\
\hline 24 & $\mathrm{~g} \mathrm{Al} / \mathrm{L}$ waste (wet) & g/L (wet) & & \\
\hline 25 & Average trapped gas temperature & ${ }^{\circ} \mathrm{F}$ & & \\
\hline 26 & Average solids temperature & ${ }^{\circ} \mathrm{F}$ & & \\
\hline 27 & $\begin{array}{l}\text { Power load from published source. If not available, } \\
\text { leave blank. }\end{array}$ & $\mathbf{k W}$ & & \\
\hline 28 & $\begin{array}{l}\text { Heat load from published source. If not available, leave } \\
\text { blank. (Don't leave both blank.) }\end{array}$ & $\mathbf{k W}$ & & \\
\hline 29 & $\begin{array}{l}\text { Tank Farm (A, AN, AP, AW, AX, AY, AZ, B, BX, BY, C, } \\
\text { S, SX, SY, T, TX, TY, U) }\end{array}$ & & & \\
\hline 30 & H2 generation rale, $\mathrm{G}(\mathrm{H} 2)$. If unknown, enter 0.1 & $\begin{array}{r}\text { molecules } \\
\mathrm{H} 2 / 100 \mathrm{eV}\end{array}$ & & \\
\hline 33 & If sampled, actual $\mathrm{H} 2$ value from sampling & ppm & & \\
\hline 34 & If sampled, actual NH3 value from sampling & Ppm & & \\
\hline 37 & $\begin{array}{l}\% \mathrm{H} 2 \text { in trapped gas, } \mathrm{ft} 3 \mathrm{H} 2 / \mathrm{ft} 3 \text { trapped gas } \times 100 \% \text {. If } \\
\text { unknown, enter } 97 \% \text {. }\end{array}$ & $\%$ & & \\
\hline 38 & $\%$ of rapped gas releasable. If urknown, enter $25 \%$. & $\%$ & & \\
\hline 39 & $\begin{array}{l}\text { Mean air pressure on waste surface. If unknown, enter } \\
14.50 \text {. }\end{array}$ & psia & & \\
\hline 40 & Add to Current Surf Lvl: compaction & in. & & \\
\hline 41 & Add to Current Surf Lvl: out leakage & in. & & \\
\hline 42 & Add to Current Surf Lvl: pumped out & in. & & \\
\hline
\end{tabular}


Table A.1. Tank Data Collection Form (2 sheets).

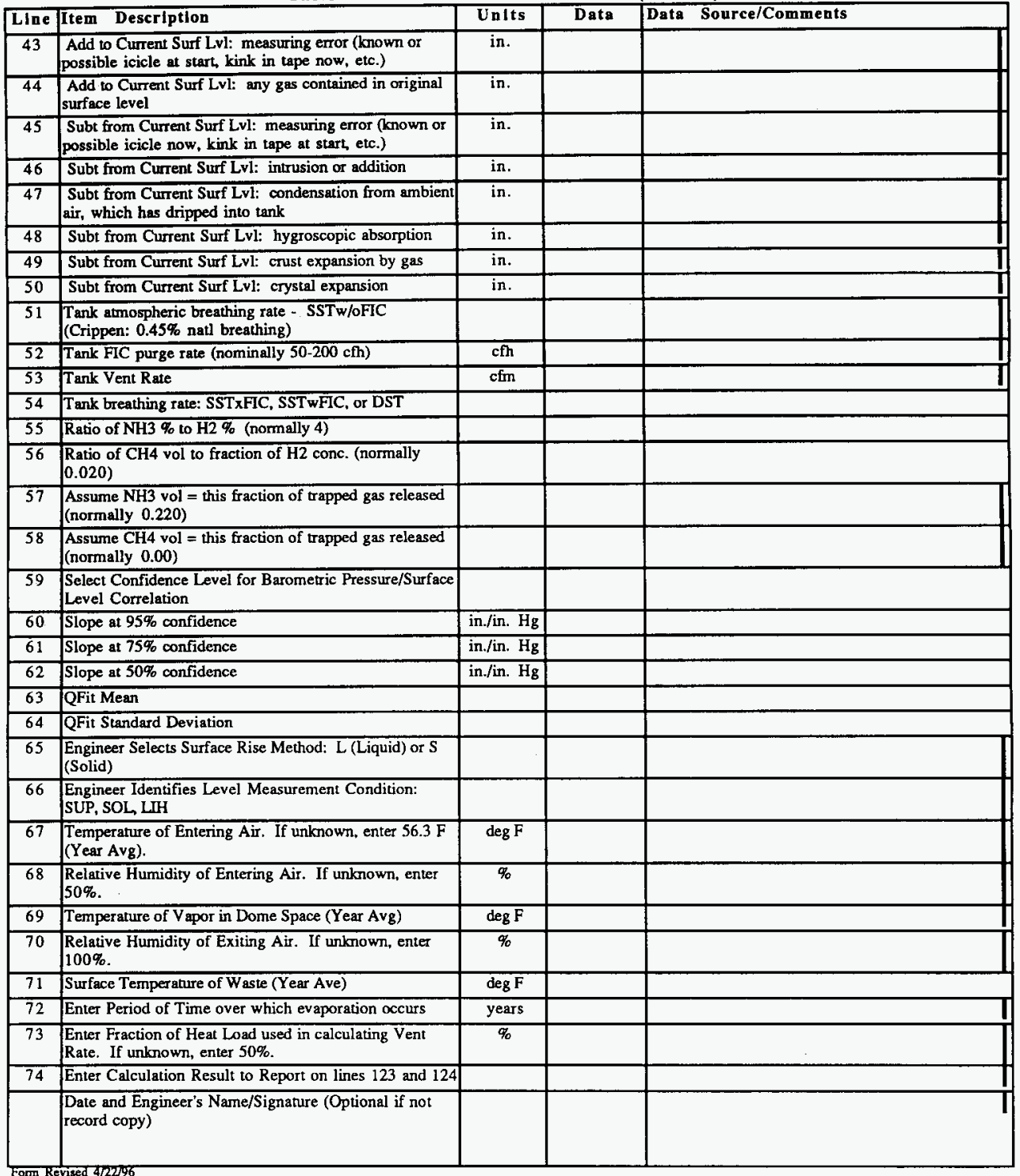


This page intentionally left blank. 
WHC-SD-WM-TI-724, Rev. 1

\section{ATTACHMENT B}

\section{LOGIC AND TECHNICAL DETAILS}


This page intentionally left blank

B-2 
The detailed logic and technical details for evaluating tank flammable gas conditions was given in Appendix E ofCriteria for Flammable Gas Watch List Tanks, WHC-EP-0702 Rev. 0, (Hopkins 1994). That appendix is reproduced on the following pages without change, except that page numbers have been changed to correpond to numbers for this attachment, Attachment B. Figures numbers are those assigned in the original appendix in WHC-EP0702 Rev. 0.

\section{REFERENCE}

Hopkins, J. D., 1994, Criteria for Flammable Gas Watch List Tanks, WHC-EP-0702 Rev 0, Westinghouse Hanford Company, Richland, Washington. 


\section{APPENDIX E [OF WHC-EP-0702, Rev 0]}

\section{LOGIC \& TECHNICAL DETAILS}

\section{TABLE OF CONTENTS}

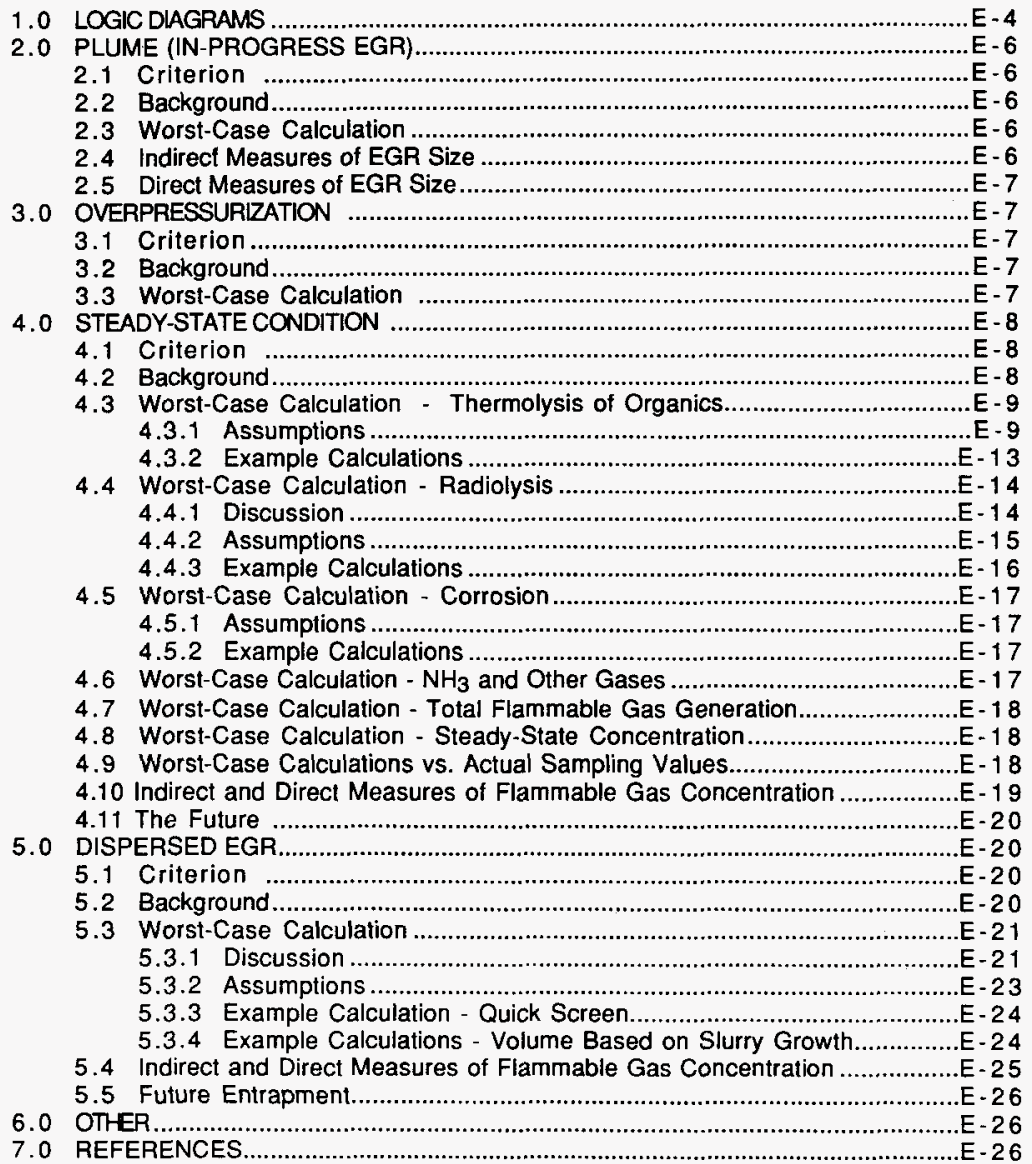




\subsection{LOGIC DIAGRAMS}

Figure E-1 is a diagram of the overall logic for the application of the flammable gas criteria. (Later in this appendix, Figure E-2 shows more-detailed logic for the dispersed-episodic gas release (dispersed-EGR) case.) On the left of the overall logic diagram are identified the four tank conditions below, which are defined in Section 2.5 of the text.

- In-progress EGR

- Overpressurization

- Dispersed-EGR condition

- Steady-state condition

For each condition, the diagram shows a three-stage approach for applying the corresponding criterion. The approach begins with conservative worst-case calculations. Next, when indirect measurement of flammable gas concentration/volume are available, additional evaluation is conducted. Finally, when direct concentration measurement is available, still further evaluation is done. At each stage all relevant available data on indirect and direct measurements must be considered.

At the first stage, worst-case calculations are done, using generally available tank data, such as waste volume, temperature and drainable liquid. If any additional second- or third-stage data are available, they must also be considered. If the calculations and data show that the tank does not exceed the Watch List criteria, it will not be placed on the Watch List.

In the absence of other data, the first-stage, worst-case calculation may not be sufficient to determine whether a tank exceeds the Watch List criteria. If it cannot be determined that a tank does not exceed the Watch List criteria, it must be placed on the Watch List. Because of the lack of data, the conservative estimate of a hazard may be much higher than the actual hazard, causing a tank to be incorrectly added to the flammable gas Watch List. Nonetheless, additional data will be required about the tank before it may be removed from the Watch List.

At the second stage, indirect measures of flammable gas concentration are considered. These include surface level fluctuations, slurry growth, indication in tank temperature records of slurry roll-over, data from similar tanks, etc. If indirect measures cannot show a tank should be excluded from the Watch List, direct measures of flammable gas concentration are required before the tank can be excluded.

At the third stage, direct measures-such as obtained through on-line gas monitors and grab samples-are considered. If they do not show a tank can be excluded from the Watch List, mitigation or remediation is required before the tank can be excluded.

The technical details for applying the criteria are described in this appendix. The methodologies herein are established in accordance with current knowledge. However, this is a living document, and the methodologies will be revised as new information becomes known or changes become necessary. Revisions will be approved by the Manager of the Flammable Gas Safety Program. 


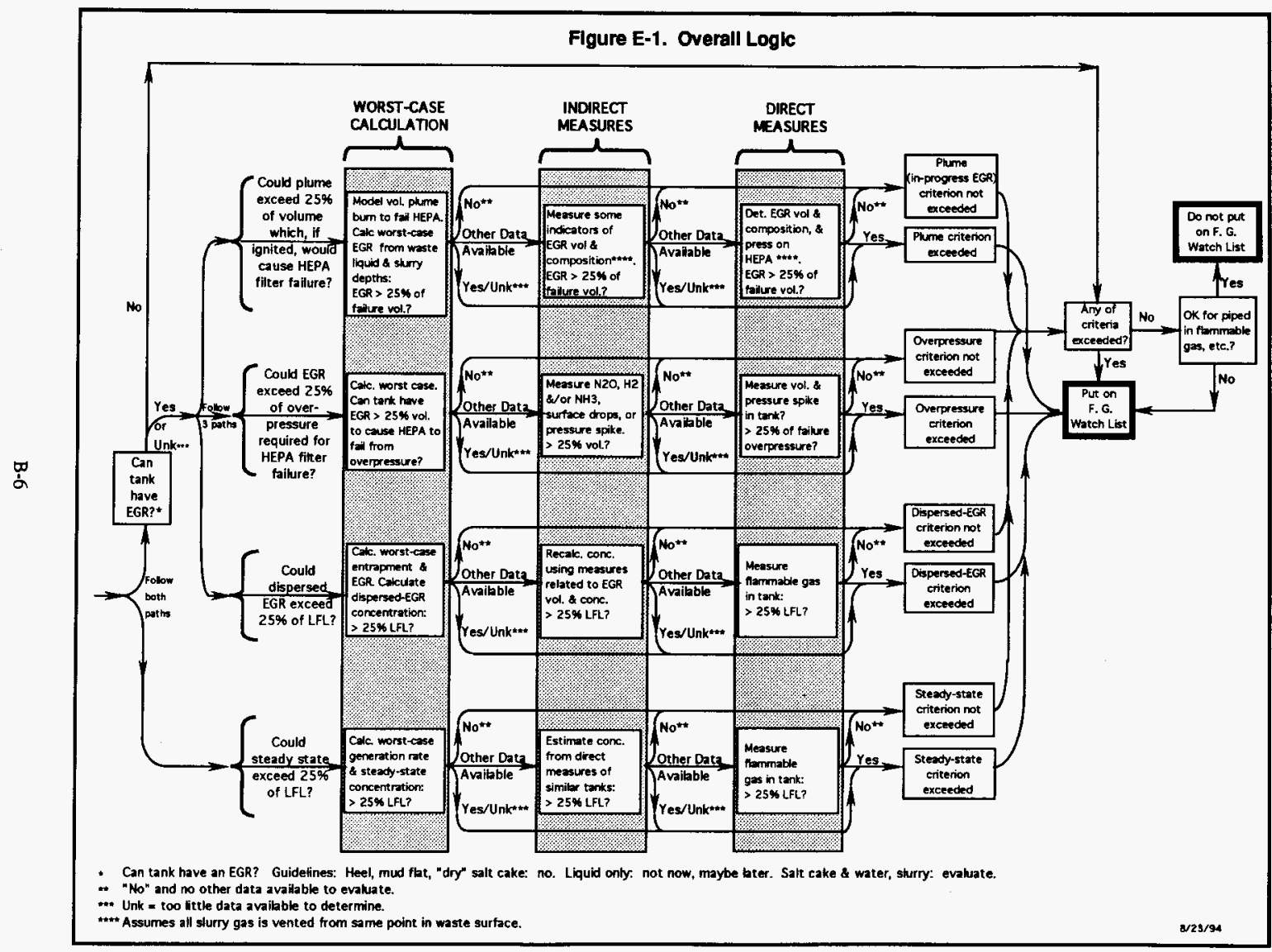




\subsection{PLUME (IN-PROGRESS EGR)}

\section{1 Criterion}

The criterion for the in-progress-EGR condition is stated below.

The tank waste could release a gas plume with a volume greater than $25 \%$ of that plume volume which, if ignited, could explode and cause a serious release to the environment.

\section{2 Background}

For the ignition of a plume (in-progress EGR), the volume of the gas release required for HEPA filter failure is assumed to be small-about $0.25 \%$ of the dome space volume. (The plume volume which, if ignited, could cause a serious release varies from tank to tank and is determined by dome space volume, exhaust configuration, and connections to other tanks.) Because this volume is much less than the volume of the tank dome space, it was questioned whether ignition of this volume was credible.

Therefore, Powers conducted an analysis of the ignition of the in-progress release and determined the probability of ignition for all non-Watch List tanks to be $6 \times 10^{-6} /$ year. (Events with an annual frequency greater than $10^{-6} /$ year are considered credible.) For tanks with conditions varying from his assumptions, the probability may be higher or lower (Powers 1993).

\section{3 Worst-Case Calculation}

Modeling analysis is being conducted to determine the volume of in-progress EGR which, when ignited, would generate enough pressure to cause HEPA filter failure. The volume of slurry gas predicted will vary from tank to tank according to the dome space volume above the tank waste, number and configuration of entry/exit ports (such as exhaust manifolds and cascade pipes to other tanks), and, if known, the composition of the slurry gas. The inputs to the model must be conservative. This may require determining the pressure produced by mixtures containing $\mathrm{NH}_{3}$ and $\mathrm{CH}_{4}$, in addition to $\mathrm{H}_{2}$ and $\mathrm{N}_{2} \mathrm{O}$.

Once the model predicts the EGR volume which would cause HEPA filter failure, tanks can be evaluated. If a tank could have an EGR of more than $25 \%$ of the volume, it must be placed on the Watch List. Whether a tank could have a release of the predicted volume can be calculated by the method, described in Section 5.0 of this appendix, to calculate the size of possible EGR for the dispersed-EGR condition.

\section{4 Indirect Measures of EGR Size}

As data become available about the composition of a tank's slurry gas and the size and frequency of EGRs, the estimate of a tank's maximum tolerable EGR can be improved. Assessments of the size of small EGRs occurring in the tank might be 
made based on short-term increases in steady-state flammable gas concentration, pressure spikes, and perhaps level fluctuations.

\section{5 Direct Measures of EGR Size}

The best measure of an in-process EGR would be a continuous gas monitor, pressure sensor, or surface-level measuring device, each with enough precision to detect significant changes in the measured parameter. Whether such devices could provide enough precision depends on the size of the maximum tolerable EGR for a given tank.

\subsection{OVERPRESSURIZATION}

\section{1 Criterion}

The criterion for overpressurization is stated below.

The tank could have an overpressure of more than $25 \%$ of the overpressure which could cause a serious release. (An overpressure of about 10 in. w.g. could cause a serious release; the amount varies from tank to tank.)

\section{2 Background}

As discussed in Section 2.0 of the document, overpressurization can cause HEPA filter failure (or release through another system opening). HEPA filters used on double-shell and single-shell tanks are rated at $10^{1}$ in. w.g. (Mil-F-51068F 1988). This overpressure corresponds to a pressure increase of $2.46 \%$ of atmospheric pressure (10.00 in. w.g./[406.78 in. w.g./1 atm] $=0.0246 \mathrm{~atm}$, or $2.49 \mathrm{kPa}$ ). This corresponds to an EGR of $2.46 \%$ of the dome space volume. With a $300 \%$ safety factor, the criterion establishes an EGR of one fourth this volume, or $0.615 \%$ of the dome space volume. If a tank could have an episodic release of this volume, the tank meets the criteria for placement on the Flammable Gas Watch List.

\section{3 Worst-Case Calculation}

Whether the tank could have a release of the predicted size can be calculated by the method, described in Section 5.0 of this appendix, to calculate the size of possible EGR for the dispersed-EGR condition.

\footnotetext{
1 Because this is a detined value, it is taken as exact, with unlimited significant figures.
} 


\subsection{STEADY-STATE CONDITION}

\section{1 Criterion}

The criterion for the steady-state condition is stated below.

The tank could have a "uniform"2 flammable gas concentration greater than $25 \%$ of the lower flammability limit (LFL) in the dome space or ventilation headers.

\section{2 Background}

Although $\mathrm{H}_{2}$ is the primary contributor to the flammable gas problem in tank waste, considerable $\mathrm{NH}_{3}$ and some $\mathrm{CH}_{4}$ are also generated. In a study cited in Section 2.2 of this document, the U.S. Bureau of Mines (USBM) tested mixtures of $\mathrm{H}_{2}$ and other gases under various conditions. From these and other tests, the following LFLs were determined in air at $27^{\circ} \mathrm{C}\left(80.6^{\circ} \mathrm{F}\right): \mathrm{H}_{2}, 4.0 \% ; \mathrm{NH}_{3}, 15 \%$; and $\mathrm{CH}_{4}, 4.8 \%$ (i.e, $5.0 \%-0.2 \%$ ) (Cashdollar et al. 1992).

Slurry gas in tank 241-SY-101 contains nitrous oxide $\left(\mathrm{N}_{2} \mathrm{O}\right)$, in which $\mathrm{H}_{2}$ has a lower LFL. The $\mathrm{N}_{2} \mathrm{O}$ concentration in the steady-state mixture is about the same as that of $\mathrm{H}_{2}$. USBM tests of $4 \% \mathrm{H}_{2} / 4 \% \mathrm{~N}_{2} \mathrm{O}$ in air did not increase the test's peak pressure, relative to $4 \% \mathrm{H}_{2}$ in air, except for a small increase when a high-energy ignitor was used (Cashdollar et al. 1992). It is therefore inferred that $\mathrm{N}_{2} \mathrm{O}$ in this range does not significantly lower the LFL. (Refer to Appendix C for more information on the USBM report.)

As discussed in Appendix $C$, when more than one of these flammable gases is present, Le Chatelier's Linear Mixing Law is used to determine whether the mixture of flammable gases exceed their combined LFL (Cashdollar et al. 1992):

$$
\left[\mathrm{H}_{2}\right] / L F L_{\mathrm{H}_{2}}+\left[\mathrm{NH}_{3}\right] / \mathrm{LFL}_{\mathrm{NH}_{3}}+\left[\mathrm{CH}_{4}\right] / L F L_{\mathrm{CH}_{4}}>\text { or }=1
$$

where "[ $\left.\mathrm{H}_{2}\right]$ " means "concentration of $\mathrm{H}_{2}$," and all terms are mole fractions in the diluted mixture in the dome space.

Whether the concentrations of flammable gases exceed $25 \%$ of their combined LFL can be determined by calculating whether the sum of the above terms is greater than 0.25 . Values for the gas concentration terms can be determined by 1) worst-case calculation, 2) a combination of calculation and indirect measures of the $\mathrm{H}_{2}$ concentration, or 3 ) direct concentration measurement, as explained below.

In flammable gas tanks, $\mathrm{H}_{2}$ is generated by thermolysis of organics, radiolysis of water, radiolysis of organics, and corrosion of the steel tank liner. All three of these mechanisms contribute to the steady-state flammable gas concentration.

2 In this document, the phrase Tlammable gas at unitorm concentration" relers to "a flammable gas mixture in a particular tank at a point in time, where the mixture's concentration and composition at any location in the tank do not vary from the average concentration and composition (at that point in time and in that lank) by more than a few percent (e.g., five to ten percent of the concentration and/or composition) in any significant volume throughout the dome space." 
The following sections explain how to calculate the contribution of these processes to the steady-state flammable gas concentration

\section{3 Worst-Case Calculation - Thermolysis of Organics}

Thermolysis may contribute a large portion of the flammable gases generated in a high-level waste tank. This section explains how to do a worst-case calculation of the amount of flammable gas generated in such tanks. In this explanation, the generic term "tank 241-XX-nnn" refers to any of the 177 tanks except tank 241 -SY-101.

In tank 241-SY-101, there are three layers: 1) the floating crust several inches thick, 2) the convecting layer (about 13.5 feet deep) consisting of a liquid which has within it convecting currents caused by the warmer slurry layer below, and 3 ) the non-convecting layer, consisting of slurry, which entraps gas generated within that layer. $\mathrm{H}_{2}$ is generated within the convecting and nonconvecting layers. Most of the $\mathrm{H}_{2}$ for continuous release comes from the convecting layer.

The worst-case calculation determines the rate of continuous release from thermolysis per unit volume of convecting layer in tank 241-SY-101, then uses that volumetric rate doubled as a bounding rate to determine the bounding continuous release rate in individual tanks. For tank 241-XX-nnn, this bounding rate is multiplied by liquid volume and three ratios of that tank's characteristics compared to tank 241-SY-101: TOC ratio, aluminate ratio, and thermolytic reaction rate ratio (rate is a function of temperature).

\section{3. 1 Assumptions}

4. 3. 1. 1 For tank 241-XX-nnn, flammable gas is continuously released into the dome space at the same rate at which it is generated. (This is conservative if the tank is still experiencing slurry growth. Furthermore, as the tank cools, further precipitation can occur, causing increased entrapment rates and, therefore, decreased steady-state release rates.)

4. 3. 1. 2 In tank 241-SY-101, since insertion of the mixer pump, which discharges entrapped gas on a regular basis, the surface level remains relatively constant. Therefore, it is assumed that the generation rate in the tank equals the release rate.

4. 3. 1. 3 In tank $241-X X-n n n$, the thermolytic reaction is assumed to take place in the liquid phase, and the rate of thermolytic generation of $\mathrm{H}_{2}$ for the steady state is proportional to the volume of liquid waste. The volume of liquid waste includes the interstitial liquid in the slurry layer.

4. 3. 1. 4 In tank $241-X X-n n n$ the $\mathrm{H}_{2}$ for continuous release is generated in both the convecting and the nonconvecting layers. (The part of the $\mathrm{H}_{2}$ that can be calculated to be retained in the slurry layer is excluded from steady. state release.)

4. 3. 1.5 In tank $241-S Y-101$, the wt. $\%$ total organic carbon (TOC) in the liquid phase is 1.07, as reported by Herting, p. $7-11$ (Herting et al. 1992). 
For tanks in which the wt. \% TOC in liquid is unknown, it is assumed that the \% TOC is $2.9 \%$ (that is, $0.1 \%$ below the criteria for organic tanks), and the TOC is in the liquid phase, unless data indicate otherwise. As calculated below, the maximum wt. \% TOC in liquid is $5.8 \%$ :

$$
\frac{0.029 \mathrm{~g} \text { TOC }}{1.00 \mathrm{~g} \text { waste }} \times \frac{1.00 \mathrm{~g} \text { waste }}{0.50 \mathrm{~g} \text { water }}=\frac{0.058 \mathrm{~g} \text { TOC }}{1.00 \mathrm{~g} \text { water }} \text { or } 5.8 \% \mathrm{TOC}
$$

Here it is assumed that the minimum amount of water in a tank is $50 \%$, even in tanks which have been pumped.

4. 3. 1. 6 Based on work by Ashby (1992b), the rate equation for the production of $\mathrm{H}_{2}$ from thermolysis of organics is assumed to be first order with respect to wt. \% TOC in solution. (Reaction is assumed to take place in the liquid phase.)

4. 3. 1. 7 Hydrogen production increases as aluminate concentration increases (Pederson and Strachan 1993). It is assumed that all aluminum (Al) reported in characterization assays exists in waste as aluminate ion. Tank 241-SY-101 "Window E" sample assays indicate that the average Al content of the waste in tank 241-SY-101 is assumed to be about $3.0 \mathrm{wt}$. $\%$. Based on work by Ashby (1992b), it is assumed that in tank 241$X X-n n n$, the rate equation for the production of $\mathrm{H}_{2}$ from organics is first order with respect to wt. \% Al dissolved in solution. (Reaction is assumed to take place in the liquid phase.)

4. 3. 1. 8 In any high-level waste tank, the rate of $\mathrm{H}_{2}$ generation by thermolysis is a function of waste temperature. Rate $=k \times e^{-E_{a} /(R T)}$, where $k$ is a constant, $E_{a}$ is activation energy in joules, $R=8.3134 \mathrm{~J} / \mathrm{K}$-mole, and $T$ is temperature in Kelvin.

Pederson and Strachan estimate that the activation energy for $\mathrm{H}_{2}$ generation in tank 241-SY-101 may be as low as $7 \mathrm{~kJ} / \mathrm{mol}$ (Pederson and Strachan 1993). This number is derived from data such as the longterm rate of slurry growth, temperature variations, volume of gas accumulated, coupled with assumptions such as the fraction of hydrogen generated by thermolysis.

Delegard experimentally determined the activation energy to be 24.5 $\mathrm{kcal} / \mathrm{mol}(102 \mathrm{~kJ} / \mathrm{mol})$ for the thermolysis of synthetic waste containing EDTA and HEDTA (Delegard 1980). HEDTA contributed to $\mathrm{H}_{2}$ gas production; EDTA did not. The activation energy, $E_{\mathrm{a}}$, was determined by Siemer to be $96 \mathrm{~kJ} / \mathrm{mol} \mathrm{H}_{2}$. Meisel used only formaldehyde as the organic component of synthetic waste and determined Ea to be $84.8 \mathrm{~kJ} / \mathrm{mole}$ (20.3 kcal/mol H2) (Strachan 1992).

By measuring the gas generated from genuine tank 241-SY-101 waste heated to 65 and $100^{\circ} \mathrm{C}$, Person determined values for $E_{a}$ ranging from 19 to $24 \mathrm{kcal} / \mathrm{mol}$ gas $(79-100 \mathrm{~kJ} / \mathrm{mol}$ ) (Goheen et al. 1993). Because the data were not analyzed statistically, an error band of $50 \%$ is assumed around a median of $21.5 \mathrm{kcal} / \mathrm{mole}(90.0 \mathrm{~kJ} / \mathrm{mol})$. This defines a range from 45.0 to $135.0 \mathrm{~kJ} / \mathrm{mol}$. 
If $\mathrm{E}_{\mathrm{a}}$ for the production of $\mathrm{H}_{2}$ in tank 241-SY-101 waste were at the upper end of this range, dramatic differences would have been seen in gas generation rates (indicated by dramatic swings in entrapment rate) when tank temperatures were at $145^{\circ} \mathrm{F}(335.9 \mathrm{~K})$, compared to current temperatures around $115^{\circ} \mathrm{F}(319.3 \mathrm{~K})$, as indicated below. With $\mathrm{E}_{\mathrm{a}}$ equal to $135 \mathrm{~kJ}$, the rate at $145^{\circ} \mathrm{F}$ would be over 12 times the rate at $115^{\circ} \mathrm{F}$.

$$
\begin{aligned}
& \text { Rate } \quad=k \times e^{-E_{a} /(\mathrm{RT})} \\
& \text { Rate at } \left.145^{\circ} \mathrm{F}=k \times e^{-135,000 /(8.3134} \times 335.9\right)=k \times 1.016 \times 10^{-21} \\
& \text { Rate at } \left.115^{\circ} \mathrm{F}=k \times e^{-135,000 /(8.3134} \times 319.9\right)=k \times 8.143 \times 10^{-23} \\
& \text { Rate at } 145^{\circ} \mathrm{F}=12.5 \times \text { Rate at } 115^{\circ} \mathrm{F}
\end{aligned}
$$

Assuming thermolysis accounts for more than half the gas generated, the rate of entrapment should have decreased dramatically when the temperature dropped from $145^{\circ}$ to $115^{\circ} \mathrm{F}$. However, tank $241-\mathrm{SY}$ 101 's rate of surface level change has not reflected these dramatic changes.

It is therefore assumed that the activation energy, $E_{a}$, for tank 241-SY101 waste is $26.0 \mathrm{~kJ} / \mathrm{mol}$, midway between the assumed lower end of Person's range $(45.0 \mathrm{~kJ} / \mathrm{mol})$ and the Pederson/Strachan value of 7 $\mathrm{kJ} / \mathrm{mol}$. With this $E_{a}$, the rate at $145^{\circ} \mathrm{F}$ is only about twice the rate at $115^{\circ} \mathrm{F}$. This is more consistent with the observed behavior of tank 241SY-101. It is further assumed that $E_{a}$ for tank $241-X X-n n n$ is the same as for tank $241-S Y-101$.

$$
\begin{aligned}
& \text { Rate at } \left.145^{\circ} \mathrm{F}=k \times e^{-26,000 /(8.3134} \times 335.9\right)=k \times 9.054 \times 10-05 \\
& \text { Rate at } 115^{\circ} \mathrm{F}=k \times e^{-26.000 /(8.3134 \times 319.9)}=k \times 5.569 \times 10.05 \\
& \text { Rate at } 145^{\circ} \mathrm{F}=1.63 \times \text { Rate at } 115^{\circ} \mathrm{F}
\end{aligned}
$$

For tanks with average temperatures below that of tank 24t-SY-101 $\left(115^{\circ} \mathrm{F}\right)$ this approach appears to give conservative results.

For tanks at temperatures above that of tank 241-SY-101, $E_{a}$ is assumed to be $90 \mathrm{~kJ} / \mathrm{mol}$ for tanks 241-SY-101 and 241-XX-nnn. Above the temperature of tank $241-S Y-101$ this gives results more conservative than an $E_{a}$ of $26 \mathrm{~kJ} / \mathrm{mol}$ and is assumed in light of Person's value of 79$100 \mathrm{~kJ} / \mathrm{mol}$.

4. 3. 1. 9 The volumetric rate of $\mathrm{H}_{2}$ generation by thermolysis in tank 241-SY101 is assumed to be the base rate for calculating the rate in the convecting layer in tank $241-\mathrm{XX}-\mathrm{nnn}$. This volumetric rate in tank $241.5 Y-101$ is calculated as described below.

- Based on Wilkins' calculation that $15.84 \mathrm{ft}^{3}\left(0.4485 \mathrm{~m}^{3}\right) \mathrm{H}_{2}$ /day were generated in tank 241-SY-101 between releases, and her assumption that this is half the amount of gas generated (1993), 31.7 
$\mathrm{ft}^{3}\left(0.4485 \mathrm{~m}^{3}\right) \mathrm{H}_{2} /$ day were generated in tank 241-SY-101. Per Section 4.5 of this appendix, $1.1 \mathrm{ft}^{3}\left(0.031 \mathrm{~m}^{3}\right)$ of this is generated by corrosion. Of the remaining $30.6 \mathrm{ft}^{3}\left(0.866 \mathrm{~m}^{3}\right), 70$ percent (21.4 $\mathrm{t}^{3}$, or $0.606 \mathrm{~m}^{3} \mathrm{H}_{2} /$ day) is estimated to be from thermolysis and 30 percent from radiolysis (Meisel et al. 1993). It is assumed this applies to the convecting and nonconvecting layers.

- Determine the base volumetric rate of thermal $\mathrm{H}_{2}$ generation by dividing $21.4 \mathrm{ft}^{3}\left(0.606 \mathrm{~m}^{3}\right) \mathrm{H}_{2} /$ day by the volume of liquid in tank 241-SY-101. The depth of the convecting layer is assumed to be 162 in. (400 in. surface - 30 in. crust -208 in. nonconvecting layer; or $4.37 \mathrm{~m}$ ), derived from Reynolds (1993). The nonconvecting layer is assumed to contain 40 percent liquid waste (Herting et al. 1992).

$21.4 \mathrm{ft}^{3} \mathrm{H}_{2} / \mathrm{d}+\left\{367.7 \mathrm{ft}^{3}\right.$ waste/in ht. [(400 in. -30 in. crust

- 208 in. NC layer $)+(208 \times 0.40$ liquid fraction $)]\}$

$$
\begin{aligned}
& =\frac{21.4 \mathrm{ft}^{3} \mathrm{H}_{2} / \mathrm{d}}{90,160 \mathrm{ft}^{3} \text { liquid waste }} \\
& =2.37 \times 10^{-4} \mathrm{ft}^{3} \mathrm{H}_{2} / \mathrm{ft}^{3} \text { liquid/d (or } 2.37 \times 10^{-4} \mathrm{~m}^{3} \mathrm{H}_{2} / \mathrm{m}^{3} \text { liquid/d) } \\
& \quad \text { or } 5.76 \times 10^{-9} \text { mole } / \mathrm{L} \text { liq waste } / \mathrm{min}
\end{aligned}
$$

Note that, based on experimentation, Meisel estimated thermal generation to be $8.7 \times 10^{-9} \mathrm{~mole} / \mathrm{L}$ liq waste $/ \mathrm{min}$ (Meisel et al. 1993). However, this rate is too high, since it would account for $32.3 \mathrm{ft}^{3}$ of $\mathrm{H}_{2}$ generation $-0.6 \mathrm{ft}^{3}$ more than the total $\mathrm{H}_{2}$ generated by tank 241-SY-101.

4. 3. 1. 10 Based on the foregoing assumptions, tank $241-X X-n n n ' s$ overall rate of $H_{2}$ generation by thermolysis is calculated as shown below:

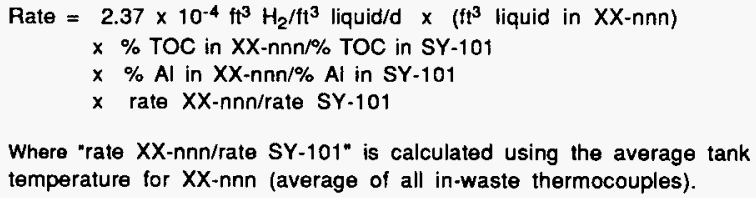

4. 3. 2. Example Calculations:

Given the following data for tank $241-X X-n n n$ :

$\begin{array}{ll}\text { Volume of expanded slurry: } & 46,943 \mathrm{ft}^{3}\left(1329.3 \mathrm{~m}^{3}\right) \\ \text { Height of slurry growth: } & 5.75 \text { in }(0.146 \mathrm{~m}) \\ \text { Water content of slurry: } & 60 \% \\ \text { Wi. \% TOC: } & 2.3 \\ \text { Aluminum wt. \% (liquid phase): } & 2.5 \\ \text { Average tank temperature: } & 26^{\circ} \mathrm{C}\left(79^{\circ} \mathrm{F}, 299 \mathrm{~K}\right)\end{array}$


Use the equation, repeated below, from Section 2.3.1.10 to determine the overall thermolysis rate for tank $241-X X-n n n$.

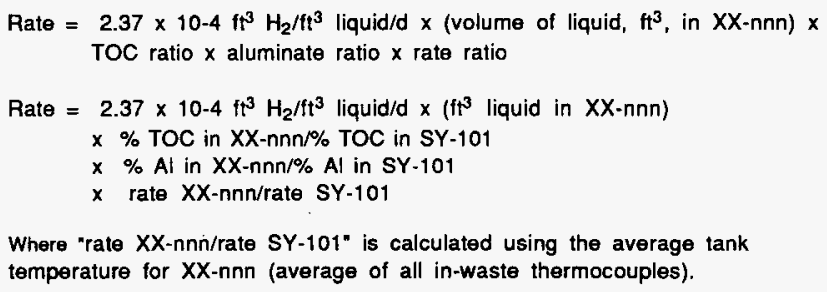

4. 3. 2. 1 Volume. Calculate the volume of liquid in tank $241-X X-n n n$, using the volumes before slurry growth began; e.g., for single-shell tank $X X-n n n$, use the volumes in November 1980.

Vol. XX-nnn $=$ Convecting layer (supernate volume) + liquid fraction of unexpanded slurry

$=$ supernate volume + [liquid fraction $\times$ (volume of expanded slurry expansion volume)]

$=(137.55$ in. -131.8 in. $)\left(367.74 \mathrm{ft}^{3} / \mathrm{in}.\right)+0.60\left[46,943 \mathrm{ft}^{3}-\right.$ $(5.75$ in. $)\left(367.74 \mathrm{ft}^{3} /\right.$ in. $\left.)\right]$

$=29,012 \mathrm{ft}^{3}=821.6 \mathrm{~m}^{3}$

4. 3. 2. 2 TOC Ratio.

The TOC ratio for the tank is calculated as follows.

$\%$ TOC in XX-nnn/\% TOC in SY-101 $=2.30 / 1.07=2.15$

4. 3. 2. 3 Aluminate Ratio.

The aluminate ratio for the tank is calculated as follows.

$\% \mathrm{Al}$ in $\mathrm{XX}-\mathrm{nnn} / \% \mathrm{Al}$ in $\mathrm{SY}-101=2.5 / 3.0=0.833$

4. 3. 2. 4 Rate Ratio.

Given an $E_{a}$ of $26 \mathrm{~kJ}$, calculate the ratio of tank $241-X X-n n n ' s$ rate to tank 241-SY-101's rate.

$\frac{X X-n n n \text { Rate }}{\text { SY-101 Rate }}=\frac{k \times \theta^{-E_{\mathbf{B}} /(\mathrm{RT})}}{k \times \theta^{-E_{\mathrm{B}} /(\mathrm{RT})}}$


Assume $\mathrm{E}_{\mathrm{a}}$ is $26 \mathrm{~kJ} / \mathrm{mol}$. Temperature for $\mathrm{XX}-\mathrm{nnn}$ is $79^{\circ} \mathrm{F}(299.3 \mathrm{~K})$ and for tank $241-\mathrm{SY}-101$ is $115^{\circ} \mathrm{F}(316.5 \mathrm{~K})$.

$$
\begin{aligned}
& \left.X X-n n n \text { Rate }=k \times e^{-26,000 /(8.3134} \times 299.3\right)=k \times 2.894 \times 10-5 \\
& \left.S Y-101 \text { Rate }=k \times \theta^{-26,000 /(8.3134} \times 319.9\right)=k \times 5.569 \times 10-5 \\
& X X \text {-nnn Rate }=0.521 \\
& \text { SY-101 Rate }
\end{aligned}
$$

4. 3. 2. 5 Thermolysis Rate for tank 241-XX-nnn.

Use the equation, from Section 4.3.2 to determine the overall thermolysis rate for tank $241-X X-n n n$.

$$
\begin{aligned}
\text { Rate }= & 2.37 \times 10.4 \mathrm{ft}^{3} \mathrm{H}_{2} / \mathrm{ft}^{3} \text { liquid/d } \times\left(\mathrm{ft}^{3} \text { liquid in } \times X-n n n\right) \times \text { TOC ratio } \\
& \times \text { aluminate ratio } \times \text { rate ratio } \\
\text { Rate }= & 2.37 \times 10-4 \mathrm{ft}^{3} \mathrm{H}_{2} / \mathrm{ft}^{3} \text { liquid } / \mathrm{d} \times\left(29,013 \mathrm{ft}^{3} \text { liquid in } \mathrm{XX} \text {-nnn }\right) \\
& \times 2.15 \times 0.833 \times 0.521 \\
= & 6.4 \mathrm{ft}^{3} \mathrm{H}_{2} / \mathrm{d}=0.15 \mathrm{~m}^{3} \mathrm{H}_{2} / \mathrm{d}
\end{aligned}
$$

\section{4 Worst-Case Calculation - Radiolysis}

4. 4. 1 Discussion

Tanks are expected to fall into one of three categories regarding predictors of radiolytic generation of hydrogen:

- Radionuclide content is known within acceptable bounds.

- Heat load can be estimated from temperature and waste volume.

- Neither radionuclide content nor heat load can be accurately determined, but volume of waste supernate is known.

When a tank's radionuclide content is known, its power load can be calculated; and, assuming a particular value for $\mathrm{G}\left(\mathrm{H}_{2}\right)$, the power load can be used to calculate a rate of $\mathrm{H}_{2}$ generation. Here, $\mathrm{G}\left(\mathrm{H}_{2}\right)$ is the number of molecules of $\mathrm{H}_{2}$ produced per 100 electron volts $(\mathrm{eV})$ of energy emitted by radioactive decay.

If the estimate of a tank's radionuclide content were inadequate for some reason, but enough were known about its temperature, waste depth, evaporation rate, and other waste parameters, then its worst-case heat load could be determined. Furthermore, a worst-case power load could be estimated and a rate of $\mathrm{H}_{2}$ generation calculated. 
If neither the radionuclide content nor the heat load could be adequately estimaled, a bounding rate of $\mathrm{H}_{2}$ generation per volume could be assumed from tank 241-SY-101, and this rate could be applied to the tank.

\section{4. 2. Assumptions}

4. 4. 2. 1 It is assumed that a $G\left(H_{2}\right)$ value of 0.100 molecule $\mathrm{H}_{2} / 100 \mathrm{eV}$ is bounding for tanks at temperatures at or below $30^{\circ} \mathrm{C}$, provided their nitrate/nitrite concentration is $2 \mathrm{M}$ or greater. Further discussion is included in Appendix $\mathrm{F}$. The $\mathrm{G}\left(\mathrm{H}_{2}\right)$ value can be used in conjunction with tank heat load to calculate the amount of hydrogen generated by radiolysis.

4. 4. 2. 2 In the absence of heat-load data, a bounding value for a tank's radiolytic $\mathrm{H}_{2}$ generation can be calculated based on a bounding volumetric rate for tank 241-SY-101. This volumetric rate in tank 241-SY-101 is calculated as described below.

- Based on Wilkins' calculation that $15.84 \mathrm{ft}^{3}\left(0.4485 \mathrm{~m}^{3}\right) \mathrm{H}_{2}$ /day were generated in tank 241-SY-101 between releases, and her assumption that this is half the amount of gas generated (1993), 31.7 $\mathrm{ft}^{3}\left(0.4485 \mathrm{~m}^{3}\right) \mathrm{H}_{2}$ /day were generated in tank 241-SY-101. Per Section 4.5 of this appendix, $1.1 \mathrm{ft}^{3}\left(0.031 \mathrm{~m}^{3}\right)$ of this is generated by corrosion. Of the remaining $30.6 \mathrm{ft}^{3}\left(0.866 \mathrm{~m}^{3}\right), 70$ percent (21.4 $\mathrm{ft}^{3}$, or $0.606 \mathrm{~m}^{3} \mathrm{H}_{2}$ /day) is estimated to be from thermolysis and 30 percent from radiolysis (Meisel et al. 1993). It is assumed this applies to the convecting and nonconvecting layers.

- Determine the volumetric rate of radiolytic $\mathrm{H}_{2}$ generation by dividing $9.2 \mathrm{ft}^{3}\left(0.261 \mathrm{~m}^{3}\right) \mathrm{H}_{2}$ /day by the volume of liquid in tank $241-\mathrm{SY}$. 101. The depth of the convecting layer is assumed to be 162 in. ( 400 in. surface - 30 in. crust -208 in. nonconvecting layer; or $4.37 \mathrm{~m}$ ), as stated by Reynolds (1993). The nonconvecting layer is assumed to contain 40 percent liquid waste (Herting et al. 1992)

$9.2 \mathrm{ft}^{3} \mathrm{H}_{2} / \mathrm{d}+\left\{367.7 \mathrm{ft}^{3}\right.$ waste/in ht. [(400 in. -30 in. crust

- 208 in. NC layer $)+(208 \times 0.40$ liquid fraction $)]\}$

$$
\begin{aligned}
& =\frac{9.2 \mathrm{ft}^{3}-\mathrm{H}_{2} / \mathrm{d}}{90,160 \mathrm{ft}^{3} \text { liquid waste }} \\
& =1.02 \times 10.4 \mathrm{ft}^{3} \mathrm{H}_{2} / \mathrm{ft}^{3} \text { liquid } / \mathrm{d} \text { (or } 1.02 \times 10.4 \mathrm{~m}^{3} \mathrm{H}_{2} / \mathrm{m}^{3} \text { liquid/d) } \\
& \quad \text { or } 2.5 \times 10^{-9} \mathrm{~mole} / \mathrm{L} \text { liq waste } / \mathrm{min}
\end{aligned}
$$

For tank 241-XX-nnn, the overall radiolytic rate of $\mathrm{H}_{2}$ generation for the steady state is proportional to the volume of liquid waste, since the thermolytic reaction is presumed to take place in the liquid phase. The volume of liquid waste includes the interstitial liquid in the slurry layer.

4. 4. 2. 3 A tank's heat load is generated by radiolysis and thermolysis (temperature-induced degradation) of tank waste. The rate of $\mathrm{H}_{2}$ generation from 
the radiolysis of water is proportional to tank heat load, less the heat generated by thermolysis.

4. 4. 2. 4 A tank's radiolytic power load decreases as its radioactivity decreases, according to the half-life equation.

\section{4. 3 Example Calculations}

4. 4. 3. 1 A tank's waste contains $2540 \mathrm{~g}{ }^{137} \mathrm{Cs}$ and $3400 \mathrm{~g}{ }^{90} \mathrm{Sr} ;{ }^{137} \mathrm{Cs}$ generates 0.427 watts $/ g$ and $90 \mathrm{Sr}$ generates 0.916 watts $/ g$. $\mathrm{G}(\mathrm{H} 2)=0.100$ molecule $/ 100 \mathrm{eV}$. Calculate the amount of $\mathrm{H}_{2}$ generated by radiolysis.

Calculate power load:

$$
\begin{aligned}
& 0.427 \text { watts } / \mathrm{g}{ }^{137} \mathrm{Cs} \times 2550 \mathrm{~g}^{137} \mathrm{Cs}=1088 \text { watts } \\
& 0.916 \text { watts } / \mathrm{g}{ }^{90} \mathrm{Sr} \times 3400 \mathrm{~g}^{90} \mathrm{Sr}=3114 \text { watts }
\end{aligned}
$$

Calculate $\mathrm{H}_{2}$ generation:

$$
\begin{aligned}
& (1088+3114) \text { watt } \times \mathrm{J} / 2.7778 \times 10^{-4} \text { watt-h } \times \text { eV/1.60219 } \times 10^{-19} \mathrm{~J} \\
& \times 0.100 \text { molecule } \mathrm{H}_{2} / 100 \text { eV } \times \text { mole/6.023 } \times 10^{23} \text { molecules } \mathrm{H}_{2} \\
& \times 0.8639 \mathrm{f13} \mathrm{H}_{2}\left(50^{\circ} \mathrm{C}\right) / \text { mole } \mathrm{H}_{2} \times 24 \mathrm{~h} / \mathrm{d} \\
& =3.3 \mathrm{ft}^{3} \mathrm{H}_{2} / \mathrm{d}=0.92 \mathrm{~m}^{3} \mathrm{H}_{2} / \mathrm{d}
\end{aligned}
$$

4. 4. 3. 2 Tank $241-X X-n n n$ has a total heat load of 5,000 Btu/h. Assume an enthalpy decrease (exothermic reaction) of $500 \mathrm{~kJ} / \mathrm{mol} \mathrm{H}_{2}$ for thermolysis. Thermolytic $\mathrm{H}_{2}$ generation is $3.0 \mathrm{ft}^{3} \mathrm{H}_{2} / \mathrm{d}$. The waste temperature is $50^{\circ} \mathrm{C}$. Calculate the amount of $\mathrm{H}_{2}$ generated by radiolysis.

Calculate the heat load generated in tank $241-X X-n n n$ by thermolytic $H_{2}$ generation of $3.0 \mathrm{ft}^{3} \mathrm{H}_{2} / \mathrm{d}$.

$$
\begin{aligned}
& \frac{3.0 \mathrm{ft}^{3}}{\mathrm{~d}} \times \frac{\mathrm{d}}{24 \mathrm{~h}} \times \frac{\mathrm{LL}}{0.0353 \mathrm{ft}^{3}} \times \frac{\mathrm{mol}}{24.5 \mathrm{~L}} \times \frac{500 \mathrm{~kJ}}{\mathrm{~mol}} \times \frac{0.9478 \mathrm{Btu}}{\mathrm{kJ}} \\
& =68 \mathrm{Btu} / \mathrm{h}=19.9 \text { watts }
\end{aligned}
$$

Calculate tank 241-XX-nnn's remaining heat load, which is generated by radiolysis. This is conservatively assumed to be the tank's radiolytic heat load.

$$
5,000 \mathrm{Btu} / \mathrm{h}-68 \mathrm{Btu} / \mathrm{h}=4,932 \mathrm{Btu} / \mathrm{h}=1445 \text { watts }
$$

Calculate $\mathrm{H}_{2}$ generation, assuming $\mathrm{G}\left(\mathrm{H}_{2}\right)$ is 0.100 molecule $\mathrm{H}_{2} / 100 \mathrm{eV}$;

$$
\begin{aligned}
& 1445 \text { watts } / \mathrm{h} \times \mathrm{J} / 2.7778 \times 10^{-4} \text { watt-h } \times \mathrm{eV} / 1.60219 \times 10^{-19} \mathrm{~J} \\
& \times 0.100 \mathrm{molecule} \mathrm{H}_{2} / 100 \mathrm{eV} \times \text { mole/6.022 } \times 10^{23} \text { molecules } \mathrm{H}_{2} \\
& \times 0.86391 \mathrm{ft}^{3} \mathrm{H}_{2}\left(\text { at } 25^{\circ} \mathrm{C}\right) / \text { mole } \mathrm{H}_{2} \times 24 \mathrm{~h} / \mathrm{d} \\
& =1.1 \mathrm{ft}^{3} \mathrm{H}_{2} / \mathrm{d}=0.032 \mathrm{~m}^{3} \mathrm{H}_{2} / \mathrm{d}
\end{aligned}
$$


4. 4. 3. 3 A tank contains 100,000 gallons of liquid waste. Neither its heat load nor its radionuclide content can be reliably estimated. Calculate $\mathrm{H}_{2}$ generation per section 4.4.2.2.

$1.02 \times 10^{-4} \mathrm{ft}^{3} \mathrm{H}_{2} / \mathrm{d} / \mathrm{ft}^{3}$ liquid waste $\times 1 \mathrm{ft}^{3} / 7.481 \mathrm{gal}$.

$\times 100,000$ gal. $=1.4 \mathrm{ft}^{3} \mathrm{H}_{2} / \mathrm{d}=0.028 \mathrm{~m}^{3} \mathrm{H}_{2} / \mathrm{d}$

\section{5. Worst-Case Calculation - Corrosion}

4. 5. 1., Assumptions

4. 5. 1. 1 None of the $\mathrm{H}_{2}$ currently generated by corrosion in tank 241-XX-nnn is entrapped. It is continuously released into the dome space to contribute to steady-state $\mathrm{H}_{2}$ concentration.

4. 5. 1.2 The $\mathrm{H}_{2}$-generation rate by corrosion in a tank with a $75-\mathrm{ft}(22.9 \mathrm{~m})$ diameter and waste $35 \mathrm{ft}(10.7 \mathrm{~m})$ deep has been calculated; 1 mil $(2.54$ $x 10-5 \mathrm{~m}$ ) of corrosion per year will produce approximately $4000 \mathrm{ft}^{3}$ $\left(113.3 \mathrm{~m}^{3}\right.$ ) of $\mathrm{H}_{2}$ (Ashby et al. 1992a). Coupons of A516 steel coupons, which was widely used in the construction of double shell tanks, were tested for corrosion in simulated wastes, with and without gamma radiation. The resulting corrosion rates ranged from 0.02 to 0.03 mil per year (Strachan 1994). To account for milder steels used in single shell tanks and for lower $\mathrm{pH}$, which allow higher corrosion rates in some tanks, a corrosion rate of 0.10 mil per year is assumed. This estimate is believed to be conservative. This corrosion rate corresponds to the $\mathrm{H}_{2}$ generation rate calculated below.

$$
\begin{aligned}
4,000 \mathrm{cu} \mathrm{ft} / \mathrm{mil} \times 0.10 \mathrm{mil} / \mathrm{yr} \times 1 \mathrm{yr} / 365 \text { days } & =1.096 \mathrm{ft}^{3} \mathrm{H}_{2} / \mathrm{day} \\
& =0.0310 \mathrm{~m}^{3} / \mathrm{day}
\end{aligned}
$$

The amount of hydrogen produced by corrosion is directly proportional to the area of steel surface exposed to moisture-containing waste. Thus, the daily production rate per square foot of exposed steel is determined as follows:

$1.096 \mathrm{ft}^{3} \mathrm{H}_{2} /$ day/area of steel exposed to waste $=$

$1.096 \mathrm{ft}^{3} \mathrm{H}_{2} / \mathrm{day} /\left(\pi \times\left(37.5^{2}+75 \times 35\right)=8.65 \times 10^{-5} \mathrm{ft}^{3} \mathrm{H}_{2} / \mathrm{day} / \mathrm{ft}^{2}\right.$

$=8.65 \times 10^{-5} \mathrm{ft}^{3} \mathrm{H}_{2} / \mathrm{day} / \mathrm{ft}^{2}$

$=2.64 \times 10^{-5} \mathrm{~m}^{3} / \mathrm{day} / \mathrm{m}^{2}$

This rate can be used to determine the amount of corrosion-generated hydrogen for any tank.

4. 5 2. Example Calculations

The surface area of tank 241-XX-nnn in contact with waste is $9.25 \times 10^{3}$ $\mathrm{ft}^{2}$. Calculate the rate of $\mathrm{H}_{2}$ production: 
$8.65 \times 10-5 \mathrm{tt}^{3} \mathrm{H}_{2} / \mathrm{d} / \mathrm{tt}^{2}$ of wall $\times 9,250 \mathrm{ft}^{2}$ wall $=0.80 \mathrm{tt}^{3} \mathrm{H}_{2} / \mathrm{d}=0.023 \mathrm{~m}^{3} \mathrm{H}_{2} / \mathrm{d}$

\section{6 Worst-Case Calculation $-\mathbf{N H}_{3}$ and Other Gases}

In calculating the flammable gas concentration, contributions of $\mathrm{NH}_{3}, \mathrm{CH}_{4}$ and other flammable gases must be considered. As noted in Section 2.3.1 of the main body of this document, high $\mathrm{NH}_{3}$ concentrations have been observed in tank 241SY-101. Assumptions regarding $\mathbf{N H}_{3}$ concentrations are given in Appendix $\mathrm{D}$. The rate of $\mathrm{CH}_{4}$ release is assumed to be only $2 \%$ of the $\mathrm{H}_{2}$ release rate. Any tank containing a floating organic layer is a special case and will be deall with under the Tank Vapor Program.

\section{7 Worst-Case Calculation - Total Flammable Gas Generation}

The total rate of $\mathrm{H}_{2}$ release into the tank $241-\mathrm{XX}$-nnn dome space is the sum of the foregoing quantities.

\section{8 Worst-Case Calculation - Steady-State Concentration}

For calculations of steady-state concentration, it is assumed that $\mathrm{H}_{2}$ is released from the waste at the same rate at which it is generated. Once the generation rate is determined, the equation below is used to determine the $\mathrm{H}_{2}$ steady-state concentration (Garfield 1975).

$$
\text { Mole fraction of } \mathrm{H}_{2}=\frac{\text { total daily generation rate }}{\text { total daily generation rate }+ \text { breathing rate }}
$$

For a daily evolution of $\mathrm{g} \mathrm{f} \mathrm{ft}^{3} \mathrm{H}_{2} / \mathrm{d}$, passively vented tanks, which have a daily breathing rate of 0.0045 times the tank's dome space volume (Crippen 1993), a more-defined equation is as follows.

$$
\text { Mole fraction of } \mathrm{H}_{2}=\frac{g \mathrm{t}^{3} / \mathrm{d}}{\left.g \mathrm{t}^{3} / \mathrm{d}+0.0045 \text { (tank vol. }- \text { waste vol. }\right) \mathrm{H}^{3} / \mathrm{d}}
$$

For a tank with an exhauster running at $E \mathrm{cu} f t / m i n$, the corresponding equation is:

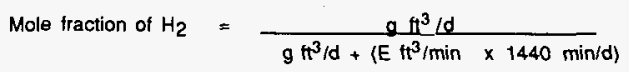

As shown below, for a tank emitting a constant $16 \mathrm{ft}^{3} \mathrm{H}_{2} / \mathrm{d}$ (as tank 241-SY-101 does in intervals between EGRs), an exhauster operating at $550 \mathrm{ft}^{3} / \mathrm{min}$ establishes a steady-state mole fraction of $\mathrm{H}_{2}$ at $2.0 \times 10^{-5}$. Even at an exhaust rate of $50 \mathrm{ft}^{3} / \mathrm{min}$, the calculated mole fraction is $4.4 \times 10^{-4} ;$ and at $5 \mathrm{ft}^{3} / \mathrm{min}$, the calculated mole fraction is $4.4 \times 10^{-3}$.

$$
\text { Mole fraction of } \mathrm{H}_{2}=\frac{16 \mathrm{t}^{3} / \mathrm{d}}{16 \mathrm{tt}^{3} / \mathrm{d}+(550 \mathrm{cfm} \times 1440 \mathrm{~min} / \mathrm{d})}=2.0 \times 10^{-5}
$$




\section{9 Worst-Case Calculations vs. Actual Sampling Values}

The foregoing calculations, when applied to some single-shell tanks, yield results more than 10 times higher than values obtained through dome space sampling. The daily breathing rate used in the calculations $10.45 \%$ of the dome space volume) may be much too low. The following may increase the turnover of dome space gas to several times the percentage: diffusion; convection currents (stack effect), where appropriate; buoyancy effects of lighter-than-air flammable gases; and the effect of wind. A modeling study is underway to more accurately estimate tank breathing rates.

Another calculation input which causes high steady-state concentrations is the fact that the $\mathrm{H}_{2}$ generation rates used, which are derived from tank 241-SY101, are substantially higher than the actual rates in other tanks. A valid method is needed to better estimate the generation rates for these other tanks.

\section{10 Indirect and Direct Measures of Flammable Gas Concentration}

As shown in Section 1.0 of this appendix, the logic for applying the criteria requires refining worst-case calculations as indirect and direct measures of flammable gas concentration become available.

Indirect measures of a tank's flammable gas concentration may be known before the concentration is measured directly. Examples are as follows.

- If the range of proportions of $\mathrm{H}_{2}, \mathrm{NH}_{3}$, and $\mathrm{N}_{2} \mathrm{O}$ generated by a tank's waste are known, and the concentration of one of them is determined, the concentrations of the remaining two can be determined within a range.

- If tanks $A$ and $B$ are connected via cascade piping or an exhaust system and the $\mathrm{H}_{2}$ concentration is measured in $A$, that may allow estimating the concentration in $\mathbf{B}$.

- Since $\mathrm{H}_{2}$ radiolysis is proportional to the amount of decay energy, it is also proportional to the tank power load. Assuming radiolysis is responsible for $40 \%$ or more of the $\mathrm{H}_{2}$ generated by a tank, it is possible to use power loads to estimate the amount of $\mathrm{H}_{2}$ generated by tanks. If a tank with a particular power load generates $10 \mathrm{ft}^{3}\left(0.28 \mathrm{~m}^{3}\right)$ of $\mathrm{H}_{2}$ per day, another tank with the same power load should generate a similar amount of $\mathrm{H}_{2}$.

The best way to determine a tank's steady-state $\mathrm{H}_{2}$ concentration is to measure it directly. The data quality must be appropriate for the level of hazard. The amount, precision and accuracy of the data required vary with the concentration of gas in the tank.

As a related matter, it is necessary to consider whether $\mathrm{H}_{2}$ can stratify in the tank's dome space because of its low molecular weight, compared to air. R. M. Wallace of Savannah River calculated that from top to bottom of a 33-ft dome space, neglecting the difference in gravity between the top and bottom, the maximum theoretical concentration gradient is only 0.001 , even without 
considering decreases in the gradient caused by convection (Wallace 1991). Providing that this is not contradicted by results of multi-level vapor sampling under the Tank Vapor Issue Resolution Program, stratification is not a source of variability in sampling, and monitoring at a single level is adequate to determine steady-state $\mathrm{H}_{2}$ concentration. Sufficient sampling must be done to provide adequate confidence that the steady-state concentration does not exceed the criterion level. The extent of sampling required will vary with the error of the technology and how far the concentration is from the criterion level.

For example, consider a tank which contains only a small amount of waste, has a low radionuclide content, and is expected to give a flammable gas concentration two orders of magnitude below the criterion level. For this tank, merely taking three gas samples within a half hour at a single point in the dome space may be adequate. However, increased rigor is required for tanks with a more variable steady-state concentration or with a concentration closer to the criterion limit.

\section{11 The Future}

To be excluded from the Waich List, a tank must have no credible scenario by which its unaugmented contents can increase their flammable-gas generation and cause the steady-state concentration to exceed $25 \%$ of the LFL.

\subsection{DISPERSED EGR}

\section{1 Criterion}

The criterion for the dispersed-EGR condition is stated below.

The tank, after an EGR has dispersed within it, could have a flammable gas concentration greater than $25 \%$ of the lower flammability limit (LFL) in the dome space or ventilation headers.

\section{2 Background}

This section applies to tanks which have, or could have, episodic releases of gas entrapped in the waste, and it addresses the condition in the tank just after the gas has dispersed throughout the dome space, and before the gas is exhausted from the tank. In actuality, in tanks which are actively exhausted, some of the gas may have been exhausted before complete dispersion occurs, but this section conservatively assumes none of the gas has been exhausted.

For a tank to have an EGR requires that the waste entrap slurry gas and that the amount of gas entrapped reach and exceed the slurry's entrapment capacity. For entrapment to occur requires: 1) the presence of sufficient organics (Pederson and Strachan 1993), 2) concentration of anions and cations high enough and waste temperature cool enough for the precipitation of solids to form a slurry layer which can entrap gas generated within the layer, and 3) the generation of slurry gas at a rate exceeding the rate at which the waste continually releases gas. 
If entrapment occurs, the waste slurry expands, which results in a rise in the waste surface level. The amount of rise depends on the amount of gas entrapped and the pressure head on the gas. Therefore, the amount of surface level rise is a measure of the amount of gas entrapped in a tank.

Unless the composition of the gas is known, it will be assumed to be $97 \% \mathrm{H}_{2}$ and $3 \%$ water vapor and other inert gases. Dividing the volume of flammable gas by the dome space volume gives the flammable gas concentration resulting from slurry gas. Whether the flammable-gas concentration can exceed $25 \%$ of the combined LFL can be determined by 1) worst-case calculation, 2) indirect measures combined with calculations of the flammable gas concentration, or 3 ) direct measurement of the concentration.

Regardless of which method is used to assess the dispersed-EGR condition, the logic requires determining whether the tank releases or could release gas, now or in the future, and whether the resulting dispersed flammable gas concentration would exceed the Watch List criteria. (A more-detailed logic for this assessment of the dispersed-EGR condition is shown in Figure 2.)

\section{3 Worst-Case Calculation}

\section{3. 1 Discussion}

The starting point in the logic is to determine whether the tank is known to have had one or more episodic gas releases. The following are evidence of such releases: 1) an abrupt surface level drop; 2) a transient increase in a tank's dome space pressure; 3) a concentration spike detected via gas monitors; and/or 4) inversion of a tank's temperature profile, indicating entrapped slurry gas has expanded and raised the warmer waste from the tank bottom to the cooler surface of the waste.

Surface level fluctuations must be evaluated in light of the long-term behavior of the surface level. In some cases, minor fluctuations may indicate the waste's entrapment capacity is too small for a significant release, or that the ongoing release rate approximates the entrapment rate, so the waste can not exhibit (further) slurry growth. On the other hand, the larger the fluctuations, the greater the entrapment and release, and the more likely a tank will be considered to have had an $\mathrm{EGR}^{3}$.

Surface-level rise and fall are allected by waste eveporation, absorption of humidity, tank leakage, in-seepage by rain water, measuring errors (such as caused by "icicles" on surface level probes), and other factors which can mask of exaggerate slurry growth. Without an improved ability to predict the effect of these factors, the error band for some lanks could be so great that the uncentainty in the surface level alone will require placing the tanks on the Watch List. Nonetheless. other tank data, such as type and/or characteristics of waste content, will exclude some tanks. 


\section{Figure E-2. Detailed Logic for Dispersed EGR}

Whether the tank is being assessed by worst-case calculation, indirect measurements, or direct measurements, the purpose is to determine whether the gas can exceed $25 \%$ of its combined LFL during an EGR. The diagram below illustrates the detailed logic to be applied in the assessment.

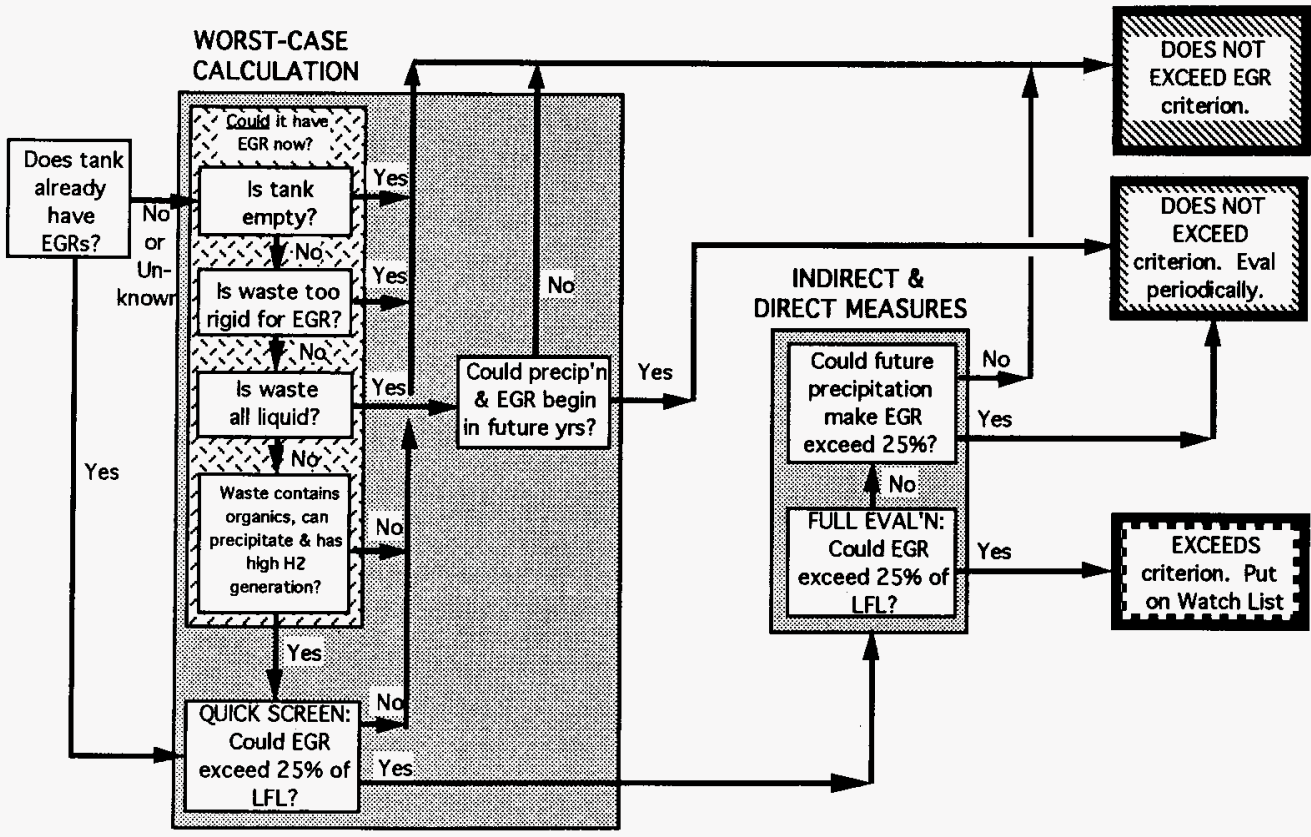


If the tank is known to have had EGRs, a worst-case calculation will be done to determine whether an EGR could cause the dome space gas to exceed the dispersed-EGR criterion. A "quick screen" will be done to determine whether the waste could hold enough gas to exceed the dispersed-EGR criterion, assuming the waste has the same volumetric entrapment capacity as tank $241-S Y-101$.

If the waste in tank 241-XX-nnn could not hold enough gas to exceed the dispersed-EGR criterion, the tank need not be evaluated further for the dispersed-EGR condition. If it could exceed the quick-screen criteria, it must be evaluated more carefully to determine whether it must be added to the Watch List. This evaluation will be done using all available data, including any indirect and direct measures of dome space gases. This method provides for characterizing each input statistically and may be used with a Monte Carlo simulation program to estimate the flammable gas concentration, within an error band; this allows determining whether the concentration is within the criterion limit, to the required confidence level. If the tank is not already known to have had EGRs, it must be evaluated to determine its potential to have an EGR in the near or distant future.

- If the tank is empty, or if the waste is too rigid to have an EGR, it will not be placed on the Flammable Gas Watch List. Determining the rigidity of the surface level requires exercising engineering judgment after examining tank photos, sample analyses, fill histories, and other available records.

- If the waste is all liquid, it will not be placed on the Flammable Gas Watch List. Nonetheless, the tank must be evaluated to determine whether, as the waste cools in the future, the waste's dissolved contents could begin to precipitate and entrap and release flammable gas. This will require engineering judgment. Entrapment is promoted by organics (Pederson and Strachan 1993) and waste of high density (Brager 1994), although these are not necessary conditions). If the tank contains negligible organics, has a low density (generally below 1.20) and shows no evidence of slurry growth, no further evaluation need be done on the tank. On the other hand, if it does have credible potential to begin entrapment in the future, it must be reevaluated periodically to determine whether entrapment has begun.

- If the waste is not all liquid (i.e., it contains solids), the tank must be evaluated to determine whether it contains sufficient organic, as described above, to cause entrapment. There is some indication that entrapment may occur in tanks which have a salt cake with a dried surface and a liquid level just below the dried surface (Kirch 1994).

\section{3. 2 Assumptions}

5. 3. 2. 1 The nonconvecting layer in tank $241-S Y-101$ is of relatively constant volume, but at any point in time the elevation of the nonconvecting layer's surface level varies across the tank. The average depth of the nonconvecting layer is assumed to be 210 inches, or $5.33 \mathrm{~m}$ (conservatively estimated from Antoniak 1993, pp. 113-117). 
5. 3. 2. 2 The worst-case entrapment of tank $241-S Y-101$ is bounding for all 177 tanks. That is, for its largest EGR (December 1991), the volume of entrapped compressed slurry gas divided by the volume of non-convecting layer is the bounding compressed entrapment volume per inch of slurry height, as shown below.

Maximum EGR:

Average nonconvecting depth: Average slurry temperature:

Average pressure on slurry gas:
$11,820 \mathrm{ft}^{3}$ slurry gas (scf) (Simpson et al. 1993) $334.7 \mathrm{~m}^{3}$ 210 in $(5.33 \mathrm{~m})$ $319 \mathrm{~K}$ 32.93 psia (227.0 kPa)

COMPRESSED WQ OF SLUPRY GAS/NCHSLUPRY:

$$
\begin{aligned}
& 11,820 \mathrm{tt}^{3}(\mathrm{sct}) \times 14.7 \mathrm{psi} / 32.93 \mathrm{psi} \times 319 \mathrm{~K} / 298.15 \mathrm{~K}=5,649 \mathrm{cu} \mathrm{t} \text { slurry gas }=160 \mathrm{~m}^{3} \\
& \begin{array}{l}
\text { volume of slume oas_(sct) } \\
\text { depth of nonconvec. layer }
\end{array}=\frac{5.649 \mathrm{ft}^{3} \text { slumy aas }}{210 \mathrm{in}}=26.90 \mathrm{ft}^{3} \text { slurry gas } / \mathrm{in} .=0.762 \mathrm{~m}^{3}
\end{aligned}
$$

5. 3. 2. 3 The slurry gas of tank $241-X X-n n n$ is $97 \% \mathrm{H}_{2}$, and the remaining $3 \%$ is water vapor and other inert gases. The percentage of $\mathrm{H}_{2}$ in slurry gas is expected to vary considerably from tank to tank, as noted by Pederson and Strachan:

These data indicate that the variance in the gas composition and the generation rates are quite large-varying over about 2 orders of magnitude. It appears, however, that the ratio of hydrogen to nitrous oxide, while variable, is a sensitive function of the waste composition (Pederson and Strachan 1993).

5. 3. 2. 4 The release of $\mathrm{NH}_{3}$ occurs as described in Appendix $\mathrm{D}$.

5. 3. 2. 5 Only the part of a saltcake below the water table is capable of entrapping slurry gas, and the drainable liquid occupies $60 \%$ of the volume of the saltcake.

\section{3. 3 Example Calculation-Quick Screen}

The maximum release of slurry gas to date was $11,820 \mathrm{scf}$, or $334.7 \mathrm{~m}^{3}$ (Simpson et al. 1993). For the sake of calculation, assume the gas is $100 \%$ $\mathrm{H}_{2}$. Using van der Waals equation below, determine that the 11,820 scf, or (334.7 $\mathrm{m}^{3}$ ) would occupy $5680 \mathrm{ft}^{3}\left(160.8 \mathrm{~m}^{3}\right)$ when compressed within the slurry in tank 241-SY-101.

$$
\left(P+n^{2} a / V^{2}\right)(V-n b)=n R T
$$

Here, $P$ is pressure in psia, $V$ is volume in $\mathrm{ft}^{3}, a=925.12 \mathrm{psia}\left(\mathrm{tt}^{3} / \mathrm{lb}\right.$ mole) $)^{2}$ and $b=0.4256 \mathrm{ft}^{3} / \mathrm{lb}$-mole, $R=19.31$ psia $\mathrm{ft}^{3} / \mathrm{lb}$-mol, and $T$ is temperature in Kelvin. 
This provides the basis for calculating the per-volume content of compressed gas in tank 241-SY-101's slurry, given 210 inches $(5.33 \mathrm{~m})$ of slurry (Alleman et al. 1993).

$$
5680 \mathrm{ft}^{3} / 210 \text { in. }=27.0 \mathrm{ft}^{3} \mathrm{H}_{2} / \text { in. slurry. }=30.1 \mathrm{~m}^{3} / \mathrm{m}
$$

To determine the volume of compressed slurry gas entrapped in 100 inches $(2.54 \mathrm{~m})$, for example, of slurry in tank $241-\mathrm{XX}-\mathrm{nnn}$, multiply the volumetric capacity in tank 241-SY-101 by the depth of slurry in tank 241-XX-nnn. Use van der Waals equation to determine the standard volume and the concentration in the tank dome space.

\section{3. 4 Example Calculations - Volume Based on Slurry Growth}

The potential volume of a gas release depends on the amount of slurry gas entrapped in the waste, which can be conservatively estimated from the waste's height of slurry growth. Any known intrusions or waste additions must be subtracted from the growth and conservative adjustments made for decreases caused by evaporation. Once the adjusted height of slurry growth has been determined, the amount of gas that can be released must be conservatively determined.

For example, for a single-shell tank, which has had slurry growth of $\mathbf{1 . 5}$ inches $(0.038 \mathrm{~m})$ calculated to yield $700 \mathrm{scf}\left(19.8 \mathrm{~m}^{3}\right)$ of released slurry gas, and a $60,000 \mathrm{ft}^{3}\left(1699 \mathrm{~m}^{3}\right)$ of dome space, it will be assumed that all the gas is released instantly into the dome space and that the gas is $97 \% \mathrm{H}_{2}$ ( $679 \mathrm{scf}$, or $19.2 \mathrm{~m}^{3}$ ), with $3 \%$ water vapor and other inert gases. Based on Appendix $\mathrm{D}$, it is assumed that $0.259 \mathrm{scf}$ (or $\mathrm{m}^{3}$ ) of $\mathrm{NH}_{3}$ is released per scf (or $\mathrm{m}^{3}$ ) of $\mathrm{H}_{2}$, or $181 \mathrm{scf} \mathrm{NH}_{3}\left(5.12 \mathrm{~m}^{3}\right)$.

These volumes can be used to calculate the mole fraction of each gas. The

679 scf $\mathrm{H}_{2} / 60,000 \mathrm{scf}$ dome space $=0.01132$ mole fraction $\mathrm{H}_{2}$

181 scf $\mathrm{NH}_{3} / 60,000$ scf dome space $=0.00302$ mole fraction $\mathrm{NH}_{3}$

The formula from section 4.2 of this appendix is used to determine the fraction of the LFL for the gas mixture.

$$
\left[\mathrm{H}_{2}\right] / \mathrm{LFL}_{\mathrm{H}_{2}}+\left[\mathrm{NH}_{3}\right] / L F L_{\mathrm{NH}_{3}}=\text { fraction of } \mathrm{LFL}
$$

where " $\left[\mathrm{H}_{2}\right]$ " means "concentration of $\mathrm{H}_{2}$," and all terms are mole fractions.

$$
\frac{0.01132}{0.000302}=0.303 \mathrm{LFL} \text {, or } 30.3 \% \text { of the combined LFL }
$$




\section{4 Indirect and Direct Measures of Flammable Gas Concentration}

As noted in Section 1.0 of this appendix, the logic for applying the criteria calls for refining worst-case calculations as indirect and direct measures of flammable gas concentration become available.

For example, data about the average size of a tank's releases and the probable range of slurry gas composition allows determining whether the resulting concentration is likely to exceed $25 \%$ of the LFL.

As with steady-state concentrations, the best way to determine a tank's dispersed-EGR flammable gas concentration is to measure it directly. As a general rule, we should determine the statistical variability of a tank's surface level fluctuations, then evaluate five EGRs to establish the relationship between surface level drop and flammable gas concentration. The length of the interval between EGRs will determine how long the tanks must be monitored. If, from the data produced, it can be established that the flammable gas concentration at the extreme case (at the 99th percentile, 2.5 SD's above the mean) is below $25 \%$ of the LFL, there is no need to monitor the tank further. Increased sampling may be required for tanks with a more variable concentration or with a concentration closer to $25 \%$ of the LFL.

\section{5 Future entrapment}

If the tank's current condition is found to not exceed the Watch List criteria, its future condition must still be evaluated to determine whether it has credible potential to increase its EGR size enough to exceed the dispersed-EGR criterion in the foreseeable future, before the tank contents are treated/removed. Engineering judgment is required to assess factors such as whether tank cooling entrapment so much that the potential resulting gas release would exceed the criterion level. This judgment involves assessing the waste volume and density, concentration of chelating organics and aluminate (for crystal formation) in the waste, dome space volume, etc. In practice, because of the sparsity of data about waste contents, this requirement may be met by reevaluating the status of tanks periodically to determine whether slurry growth is increasing.

\subsection{OTHER}

Regarding the foregoing conditions, if it has been found that a tank does not belong on the Watch List, the tank must be evaluated for other potential hazards. For example, if tank $A$ is connected to tank $B$ by cascade lines or common exhaust system, and evaluation determines that gas inflow from tank $B$ can cause tank $A$ to contain a mixture which exceeds the criteria, tank $A$ will be placed on the Watch List. 


\subsection{REFERENCES}

Alleman, R. T., T. M. Burke, D. A. Reynolds, D. A. Simpson, 1993, Assessment of Gas Accumulation and Retention - Tank 241-SY-101, WHC-EP-0576, Rev 0. Westinghouse Hanford Company, Richland, Washington.

Antoniak, Z. I., 1993, Historical Trends in Tank 241-SY-101 Waste Temperatures and Levels, PNL-8880/AD-940, Pacific Northwest Laboratory, Richland, Washington.

Ashby, E. C., C. Jonah, D. Meisel, L. R. Pederson, and D. M. Strachan, 1992a, Gas Generation and Retention in Tank 101-SY: A Summary of Laboratory Studies, Tank Data, and Information Needs, PNL-8124/AD-940. Pacific Northwest Laboratory, Richland, Washington.

Ashby, E. C., E. K. Barefield, C. L. Liotta, H. M. Neumann, F. Doctorovich, A. Konda, K. Zhang, J. Hurley, D. Boatright, A. Annis, G. Pansino, M. Dawson, M Juliao, 1992b, Mechanistic Studies Related to the Thermal Chemistry of Simulated Wastes Which Mimic Contents of Tank 101-SY, paper presented at American Chemical Society Symposium, "Emerging Technologies for Hazardous Waste Management," Atlanta, Georgia.

Brager, H. R., 1994, Summary of Information on Flammable Gas Watch List Tanks, WHC-EP-0711, Westinghouse Hanford Company, Richland, Washington.

Cashdollar, K. L., M. Herzberg, I. A. Zlochower, C. E. Lucci, G. M. Green, R. A. Thomas, 1992, Laboratory Flammability Studies of Mixtures of Hydrogen, Nitrous Oxide, and Air, WHC-SD-WM-ES-219, Rev. 0, Westinghouse Hanford Company, Richland, Washington.

Crippen, M. D., 1993, Barometric Pressure Variations, WHC-EP-0651, Westinghouse Hanford Company, Richland, Washington.

Delegard, C. H., 1980, Laboratory Studies of Complexed Waste Slurry Volume Growth in Tank 241-SY-101, RHO-LD-124, Rockwell Hanford Operations, Richland, Washington.

Gartield, J. S., 1975, Maximum Anticipated Hydrogen Concentrations in Underground Tank Atmospheres from Radiolysis of Water, ARH-CD-267, Atlantic Richfield Hanford Company, Richland, Washington.

Goheen, S. C., G. M. Mong, G. Pillay, N. G. Colton, J. C. Person, 1993, Evaluation of Alternative Technologies for the Destruction of Organics and Ferrocyanides in Hanford Tank Waste: Corona Discharge, Heat and Digestion, and Electrochemical Oxidation, TWRSPP-93-070, Pacific Northwest Laboratory, Richland, Washington.

Herting, D. L., D. B. Bechtold, B. E. Hey, B. D. Keele, L. Jensen, T. L. Welsh, 1992, Laboratory Characterization of Samples Taken in December 1991 (Window E) from Hanford Waste Tank 241-SY-101, WHC-SD-WM-DTR-026, Rev 0, p. 7-11, Westinghouse Hanford Company, Richland, Washington. 
Kirch, N. W., 1994, Evaluation of 241-T-111 Propensity for Flammable Gas Accumulation (internal memorandum 7E310-94-016, to G. D. Johnson, March 28), Westinghouse Hanford Company, Richland, Washington.

Meisel, D., C. D. Jonah, S. Kapoor, M. S. Matheson, and M. C. Sauer, Jr., 1993, Radiolytic and Radiolytically Induced Generation of Gases from Synthetic Waste, ANL-93/43, Argonne National Laboratory, Argonne, Illinois.

Mil-F-51068F, 1988, Filters, Particulate (High-Efficiency Fire Resistant), Military Specification.

Pederson, L. R. and D. M. Strachan, 1993, Status and Integration of the Gas Generation Studies Performed for the Hydrogen Safety Program-FY 1992 Annual Report, PNL-8523/AD-940, Pacific Northwest Laboratory, Richland, Washington.

Powers, T. A., 1993, Letter Report on Determining Probabilistic Criteria for Flammable Gas Watch List Tanks, (internal letter to G. D. Johnson, 2922093-TBP-043, dated December 3), Westinghouse Hanford Company, Richland, Washington.

Reynolds, D. A., 1993, Tank 101-SY Window E Core Sample: Interpretation of Results, WHC-EP-0628, Westinghouse Hanford Company, Richland, Washington.

Simpson, D. E., R. P. Anantatmula, G. M. Christensen, C. E. Leach, and D. D. Stepnewski, 1993, Flammable Gas Safety Issue Review Tank 241-SY-101, WHC-EP-0578, Westinghouse Hanford Company, Richland, Washington.

Strachan, D., 1992, A Summary of the Coordination Meeting Between the Participants of the Synthetic Waste Studies in the Hydrogen Safety Project, letter report, Pacific Northwest Laboratory, Richland, Washington.

Strachan, D. M., 1994, Status and Integration of the Gas Generation Studies Performed for the Hydrogen Safety Program-FY 1993 Annual Report, PNL9459, Pacific Northwest Laboratory, Richland, Washington.

Wallace, R. M., 1991, Hydrogen Mixing in Waste Tank Vapor Space, (internal letter WSRC-RP-91-95 to D. L. McIntosh, January 3), Westinghouse Savannah River Company, Aiken, South Carolina.

Wilkins, N. E., 1993, Summary of Vapor Analysis from Flammable Gas Watchlist Tanks, WHC-SD-WM-TI-548-548, Rev 0, Westinghouse Hanford Company, Richland, Washington. 
This page intentionally left blank. 
WHC-SD-WM-TI-724, Rev. 1

ATTACHMENT C

\section{SPREADSHEET AND INSTRUCTIONS}


This page intentionally left blank 
Pages C-5 through C-13 of this attachment are instructions for using the Excel ${ }^{\text {TM }}$ spreadsheet used to evaluate the tanks. The spreadsheet performs the calculations described in Sections 4.0 through 8.0. Pages C-14 through C-27 are a printout of the most recent version of the spreadsheet, which includes data for tank 241-S-106. Following the spreadsheet is a Don't Say It-Write It! (DSI) by S. A. Barker providing background on the evaporation calculations performed by the spreadsheet. Conventions for using the spreadsheet are as follows:

\section{SOLIDS SURFACE LEVEL VS. LIQUID LEVEL}

To use the spreadsheet, determine where the liquid level is relative to the solids level. When the liquid is above the solids level, the rise and fall of the liquid should closely match the expansion and contraction of the trapped gas. When the liquid is below the solids level, and the solids surface does not rise and fall but the interstitial liquid level (ILL) does, the ILL movement is magnified by the fact that the liquid is moving in pores. The apparent ILL rise or slope from such ILL movement must be scaled down by multiplying Whitney's barometric slope by the solid's porosity to get the actual slope.

\section{VOLUME OF WET SOLIDS}

Examine the surface level plots from the PC-SACS database and tank photographs. For a tank with no supernate layer per Hanlon (1995), determine whether the liquid level is at or just below the top of the solids surface.

- If yes, then the FIC measures liquid and solids at the same time. Calculate the wet solids volume from the FIC.

- If not, the FIC measures solids only, and the neutron probe measures the $\Pi L L$, which is below the solids level. Calculate the wet solids volume from the ILL.

- If it cannot be determined, there is ILL data on PC-SACS, and the neutron probe reading is below the FIC level, assume that the ILL measures liquid and the FIC measures solids. Calculate the wet solids volume from the ILL.

- If it cannot be determined, and there is no ILL data on PC-SACS, calculate the wet solids volume from Hanlon's interstitial liquid (IL) volume.

\section{SELECTING DATA}

When two devices measure the same variable, use the data from the higher-quality instrument. For | example, if there are data from an ENRAF gauge (resolution \pm 0.01 in.), FIC gauge (resolution $\pm 0.1 \mathrm{in}$.), and a manual tape (resolution $\pm 0.25 \mathrm{in}$.) use the data in the following order: ENRAF, FIC, and manual tape. There is a caution: a few ENRAFs "stick" and make a stair-step change at 9 a.m. each morning; in such cases, ENRAF data are not of higher quality than FIC data. 


\section{SURFACE LEVEL RISE}

If the surface level is falling, but the ILL is rising, there is a rise in $\mathrm{L}$. It is assumed that if the waste surface is dry solids and there is no significant exposed liquid pool, then the evaporation rate is essentially zero, and the ILL is not affected by evaporation. If the exposed solids surface level is falling, and the ILL is falling or stationary, there is no rise.

\section{BAROMETRIC ANALYSIS}

- If a tank is not on Whitney's list of 58 tanks, his analysis did not show significant statistical evidence of gas. Do not perform a barometric analysis on the tank.

- If the tank has a supernate layer, Whitney's analysis of good surface level data did not show statistical evidence of gas, and the ILL data did show statistical evidence of gas, then there is no basis for a barometric analysis because ILL data are considered the most unreliable.

- If the tank has no supernate layer, Whitney analysis based on contact with solids predicts no gas, but analysis of the ILL slope predicts gas, use the ILL slope to calculate trapped gas volume.

- If the tank has no supernate layer and Whitney analysis based on contact with solids predicts gas, but analysis of the $I L L$ slope predicts no gas, use the SL slope to calculate trapped gas volume.

- If Whitney's analysis of the FIC data predicts no gas, but analysis of the manual tape data predicts gas, accept the FIC data and conclude there is no gas in the waste.

- If Whitney's analysis of the FIC data predicts gas, but analysis of the manual tape data predicts no gas, use the FIC data.

Table C-1. Decision Summary

\begin{tabular}{|c|c|c|c|}
\hline $\begin{array}{c}\text { SL is for } \\
\text { supernate }\end{array}$ & $\begin{array}{c}\text { Whitney predicts } \\
\text { gas based on SL }\end{array}$ & $\begin{array}{c}\text { Whitney predicts } \\
\text { gas based on ILL }\end{array}$ & $\begin{array}{c}\text { Should tank be given } \\
\text { barometric evaluation for } \\
\text { trapped gas? }\end{array}$ \\
\hline \hline Yes & No & No & No \\
\hline Yes & No & Yes & No \\
\hline Yes & Yes & No & Yes. Use SL data \\
\hline No & No & No & No \\
\hline No & No & $\begin{array}{c}\text { Yes } \\
\text { (ILL below SL) }\end{array}$ & $\begin{array}{c}\text { Yes. Use ILL data. } \\
\text { LIH flag, line 66 }\end{array}$ \\
\hline No & Yes & No & Yes. Use SL data. \\
\hline
\end{tabular}




\section{PRIORITIES}

In general, if the monthly waste status report (Hanlon) says there is supernate, this is considered accurate unless pumping has begun in the tank since the report was published. If the most recent tank photographs show no supernate, assume there is none, regardless of what the report says.

\section{INSTRUCTIONS}

Table C-2 contains instructions for filling in the Excelim spreadsheet. These instructions have evolved continually during the evaluation period; the instructions are the ones used by the evaluation team in March 1966. The line description are taken directly from the spreadsheet, therefore they are not edited. Some line numbers are missing because the lines have been deleted from the spreadsheet.

Table C-2. Instructions for Filling in the Excelm Spreadsheet ( 9 sheets).

\begin{tabular}{|c|c|c|}
\hline Line & Description & Instruction/Comment/Explanation \\
\hline 3 & Total waste volume & Enter vol. from Hanlon (1995). \\
\hline 4 & $\begin{array}{l}\text { Total solids volume (sludge }+ \\
\text { saltcake), includes gas }\end{array}$ & Enter vol. from Hanlon 1995. \\
\hline 5 & Supernate volume & $\begin{array}{l}\text { Enter vol. from Hanlon } 1995 \text {. After entering lines } \\
\text { 3-5, check lines } 79-99 \text { to see whether the values } \\
\text { Excel }^{\mathrm{TM}} \text { calculates are reasonable. }\end{array}$ \\
\hline 6 & Volume of interstitial liquid & $\begin{array}{l}\text { This is a crucial volume. } \\
\text { For tanks with a supernate layer, this volume is } \\
\text { used to calculate the generation rate by thermolysis } \\
\text { and corrosion. Enter the volume calculated on line } \\
84 \text { of the spreadsheet. } \\
\text { For tanks that have been pumped (i.e., have no } \\
\text { supernate layer above the solids), this volume is } \\
\text { used to calculate the head on trapped gas, wet } \\
\text { solids volume, overall void fraction in wet solids, } \\
\text { and the generation rate by thermolysis and } \\
\text { corrosion. Preferentially use ILL data; otherwise, } \\
\text { calculate the volume as illustrated in Swaney } 1994 \text {, } \\
\text { in a way which gives the most realistic, but still } \\
\text { conservative, value. }\end{array}$ \\
\hline 7 & Volume of sludge & Enter volume from Hanlon 1995. \\
\hline
\end{tabular}


Table C-2. Instructions for Filling in the Excelm Spreadsheet ( 9 sheets).

\begin{tabular}{|c|c|c|}
\hline Line & Description & Instruction/Comment/Explanation \\
\hline 8 & $\begin{array}{l}\text { Current solid surface level height } \\
\text { (Reading SLC) }\end{array}$ & $\begin{array}{l}\text { Enter the current level from PC-SACS or volume } \\
\text { based on information in Hanlon 1995, temperature } \\
\text { profiles, or other sources. For a tank with } \\
\text { supernate, the evaluator can use the spreadsheet to } \\
\text { calculate SLC (surface level, current) as follows: } \\
\text { on line } 4 \text { enter the volume reported in Hanlon and } \\
\text { in line } 14 \text { enter Hanlon. This calculates current } \\
\text { solid level (SLC) on line } 97 \text {. Enter this value in } \\
\text { line } 8 \text {, then change line } 14 \text { to SLC. In column titled } \\
\text { Data Sources/Comments, enter type gauge, such as } \\
\text { auto FIC, or enter "calculated from Hanlon." }\end{array}$ \\
\hline 9 & $\begin{array}{l}\text { Original solid surface level height } \\
\text { (Reading SLH) }\end{array}$ & $\begin{array}{l}\text { Enter the original level from PC-SACS, if } \\
\text { available. Otherwise, enter best level available } \\
\text { from other source(s). In column titled Data } \\
\text { Sources/Comments, enter type gauge, such as auto } \\
\text { FIC. (SLH = surface level, historical) }\end{array}$ \\
\hline 10 & as of this date & Enter date of original solids level height. \\
\hline 11 & $\begin{array}{l}\text { Current liquid level height (Reading } \\
\text { LLC) }\end{array}$ & $\begin{array}{l}\text { For a tank with a supernate layer, enter its current } \\
\text { liquid level reading. For a tank with no supernate, } \\
\text { enter the current IIL reading or use the spreadsheet } \\
\text { to calculate LLC; that is, enter in line } 6 \text { the value } \\
\text { calculated per Swaney, and in line } 15 \text { enter } \\
\text { Hanlon. This calculates a current liquid level } \\
\text { height on line } 99 \text {. Enter this value on line } 11 \text {. }\end{array}$ \\
\hline 12 & $\begin{array}{l}\text { Original liquid level height } \\
\text { (Reading LLH) }\end{array}$ & $\begin{array}{l}\text { Enter the historical liquid level. This may be the } \\
\text { waste's liquid surface level in } 1981 \text {, for example, } \\
\text { or it could be the earliest ILL in the mid- to late- } \\
1980 \text { s. }\end{array}$ \\
\hline 13 & as of this date & Enter date of original liquid level height. \\
\hline 14 & $\begin{array}{l}\text { Engineer selects source of solids } \\
\text { volume (Hanlon, SLC or LLC) }\end{array}$ & $\begin{array}{l}\text { In general, for a tank with supernate, enter SLC } \\
\text { (see instructions for line 8) for tanks with known } \\
\text { surface level. For tanks in which the liquid and } \\
\text { solid levels are the same (e.g., tanks that have been } \\
\text { pumped) enter LLC. For pumped tanks in which } \\
\text { the ILL is below the solids level, enter SLC. }\end{array}$ \\
\hline 15 & $\begin{array}{l}\text { Engineer selects source of } \\
\text { interstitial liquid volume (Hanlon, } \\
\text { SLC or LLC) }\end{array}$ & $\begin{array}{l}\text { If there is supernate, enter SLC; if not, LLC. } \\
\text { Enter Hanlon only if there is no liquid level } \\
\text { measurement below the solid upper surface. }\end{array}$ \\
\hline 16 & $\begin{array}{l}\text { Engineer selects source of } \\
\text { supernate volume (Hanlon, SLC or } \\
\text { LLC) }\end{array}$ & $\begin{array}{l}\text { If there is a supernate layer, enter LLC. Enter } \\
\text { Hanlon only as a last resort. }\end{array}$ \\
\hline
\end{tabular}


Table C-2. Instructions for Filling in the Excelm Spreadsheet (9 sheets).

\begin{tabular}{|c|c|c|}
\hline Line & Description & Instruction/Comment/Explanation \\
\hline 17 & $\begin{array}{l}\text { Supernate density. If unknown, } \\
\text { enter } 1.40 \text {. }\end{array}$ & $\begin{array}{l}\text { Enter the value from Tank Characterization Report } \\
\text { if available; otherwise, enter the value from other } \\
\text { lab data. If no number is available, enter the } \\
\text { assumed mean value, } 1.40 \mathrm{~g} / \mathrm{mL} \text {. If the only } \\
\text { number available is reported as specific gravity } \\
\text { (SpG), which approximates density, assume this is } \\
\text { density. }\end{array}$ \\
\hline 18 & $\begin{array}{l}\text { Solids density. If unknown, enter } \\
1.80 \text {. }\end{array}$ & $\begin{array}{l}\text { Enter value from Tank Characterization Report if } \\
\text { available; otherwise, enter the value from other lab } \\
\text { data. If no number is available, enter the assumed } \\
\text { mean value, } 1.80 \mathrm{~g} / \mathrm{mL} \text {. If the only number } \\
\text { available is reported as SpG, assume this is } \\
\text { density. }\end{array}$ \\
\hline 19 & $\begin{array}{l}\text { Porosity (liquid fraction) in solids, } \\
\text { by assay. If unknown, enter } \\
0.501 .\end{array}$ & $\begin{array}{l}\text { If the value has been determined from waste } \\
\text { sample, enter the value. Otherwise, enter } 0.501 \text {, } \\
\text { the average value determined by Colson and } \\
\text { Whitney (1995). }\end{array}$ \\
\hline 20 & $\begin{array}{l}\text { Porosity (sludge). If unknown, } \\
\text { enter } 0.16 .\end{array}$ & $\begin{array}{l}\text { If the value has been determined from waste } \\
\text { sample, enter the value. Otherwise, enter } 0.16 \text {, the } \\
\text { average value determined by Colson and Whitney. }\end{array}$ \\
\hline 21 & $\begin{array}{l}\text { Average gas location: fraction of } \\
\text { wet solids from bottom center. If } \\
\text { unknown, enter } 0.225 \text {. }\end{array}$ & Enter 0.225 (see Section 7.4 and Attachment E). \\
\hline 22 & Estimated maximum evaporation & $\begin{array}{l}\text { If psychrometric data are available and can be used } \\
\text { to estimate evaporation, enter the estimate here. } \\
\text { Then, if INP is entered on line } 53 \text {, Excel } \mathrm{TM} \text { will } \\
\text { use this value to override any value calculated by } \\
\text { the spreadsheet. If a good estimate cannot be } \\
\text { made, leave this line blank. } \\
\text { Additional discussion of evaporation is included in } \\
\text { S. A. Barker's DSI, later in this attachment. }\end{array}$ \\
\hline 23 & g TOC/L waste (wet) & $\begin{array}{l}\text { Enter value from Tank Characterization Report if it } \\
\text { is available. Otherwise, use other lab data. In the } \\
\text { absence of data, see Toth et al. (1994). }\end{array}$ \\
\hline 24 & g Al/L waste (wet) & $\begin{array}{l}\text { Enter value for liquid assay from Tank } \\
\text { Characterization Report if available; otherwise, use } \\
\text { other lab data. Assume all aluminum reported in } \\
\text { the liquid assay is present as aluminate ion, } \mathrm{AlO}_{2}^{-} \\
\text {(see Attachment E, paragraph } 4.3 .1 .7 \text { of Hopkins } \\
(1994) \text {. }\end{array}$ \\
\hline 25 & Average trapped gas temperature & $\begin{array}{l}\text { From the temperatures obtained from } \\
\text { PC-SACS data base, estimate the temperature at the } \\
\text { height of the center of trapped gas: } 0.225 \times \text { depth of } \\
\text { wet solids, above center bottom of tank. }\end{array}$ \\
\hline
\end{tabular}


Table C-2. Instructions for Filling in the Excelm Spreadsheet (9 sheets).

\begin{tabular}{|c|c|c|}
\hline Line & Description & Instruction/Comment/Explanation \\
\hline 26 & Average liquid temperature & $\begin{array}{l}\text { Enter the estimated average temperature of the tank } \\
\text { liquid (supernate + interstitial liquid). As an } \\
\text { alternative, it's conservative to enter the average } \\
\text { temperature of the total waste. }\end{array}$ \\
\hline 27 & $\begin{array}{l}\text { Power load from published source. } \\
\text { If not available, leave blank. }\end{array}$ & Enter power load from published source. \\
\hline 28 & $\begin{array}{l}\text { Heat load from published source. } \\
\text { If not available, leave blank. } \\
\text { (Don't leave both blank.) }\end{array}$ & $\begin{array}{l}\text { If there is no power load listed in a published } \\
\text { source, enter the heat load published in Graves } \\
\text { (1994). }\end{array}$ \\
\hline 29 & $\begin{array}{l}\text { Tank Farm (A, AN, AP, AW, AX, } \\
\text { AY, AZ, B, BX, BY, C, S, SX, } \\
\text { SY, T, TX, RT, U) }\end{array}$ & Self-explanatory \\
\hline 30 & $\begin{array}{l}\mathrm{H} 2 \text { generation rate, } \mathrm{G}\left(\mathrm{H}_{2}\right) \text {. If } \\
\text { unknown, enter } 0.1 \text {. }\end{array}$ & $\begin{array}{l}\text { Enter } \mathrm{G}\left(\mathrm{H}_{2}\right) \text { from Graves, if available. Otherwise, } \\
\text { enter } 0.10 \text {. }\end{array}$ \\
\hline 33 & $\begin{array}{l}\text { If sampled, actual } \mathrm{H}_{2} \text { value from } \\
\text { sampling }\end{array}$ & Self-explanatory \\
\hline 34 & $\begin{array}{l}\text { If sampled, actual } \mathrm{NH}_{3} \text { value from } \\
\text { sampling }\end{array}$ & Self-explanatory \\
\hline 37 & $\begin{array}{l}\% \mathrm{H} 2 \text { in trapped gas, } \mathrm{ft} 3 \mathrm{H} 2 / \mathrm{ft} 3 \text { gas } \\
\times 100 \% \text {. If unknown, enter } 97 \% \text {. }\end{array}$ & Enter 0.97 \\
\hline 38 & $\begin{array}{l}\% \text { of trapped slurry gas releasable. } \\
\text { If unknown, enter } 25 \% \text {. }\end{array}$ & $\begin{array}{l}\text { Use } 25 \% \text {. Note: For DST AY-101, a bounding } \\
\text { release of } 47 \% \text { was determined by LANL's } \\
\text { Raleigh-Taylor/Neutral Buoyancy method. For } \\
\text { DSTs, see Section } 7.4 \text {. }\end{array}$ \\
\hline 39 & $\begin{array}{l}\text { Mean air pressure on waste surface. } \\
\text { If unknown, enter } 14.50 \text {. }\end{array}$ & $\begin{array}{l}\text { This pressure determines the pressure on the } \\
\text { trapped gas and the expansion when the gas is } \\
\text { released: expansion }=(\text { head }+P) / P \text {. }\end{array}$ \\
\hline 40 & Add to Current Sfc Lvl: compaction & Not yet defined \\
\hline 41 & Add to Current Sfc Lvl: out leakage & Self-explanatory \\
\hline 42 & Add to Current Sfc Lvl: pumped out & Self-explanatory \\
\hline 43 & $\begin{array}{l}\text { Add to Current Sfc Lvl: measuring } \\
\text { error (known or possible icicle at } \\
\text { start, kink in tape now, etc.) }\end{array}$ & Self-explanatory \\
\hline
\end{tabular}


Table C-2. Instructions for Filling in the Excel'm Spreadsheet ( 9 sheets).

\begin{tabular}{|c|c|c|}
\hline Line & Description & Instruction/Comment/Explanation \\
\hline 44 & $\begin{array}{l}\text { Add to Current Sfc Lvl: any gas } \\
\text { contained in original surface level }\end{array}$ & $\begin{array}{l}\text { Welty (1988) tracks cumulative unexplained slurry } \\
\text { growth, as far back as the } 1950 \text { s or } 1960 \text { s for some } \\
\text { tanks. Unless this growth can be attributed to some } \\
\text { other cause, such as known intrusion, it is assumed } \\
\text { to have come from trapped gas. The gas is } \\
\text { assumed to have been trapped around the center of } \\
\text { the tank waste. Removal of supernate from above } \\
\text { solids is assumed not to remove gas trapped in the } \\
\text { solids. Only when interstitial liquid is pumped } \\
\text { from saltcake is gas assumed to escape-from the } \\
\text { part of the saltcake from which the interstitial liquid } \\
\text { is removed. }\end{array}$ \\
\hline 45 & $\begin{array}{l}\text { Subt from Current Sfc Lvl: } \\
\text { measuring error (known or possible } \\
\text { icicle now, kink in tape at start, } \\
\text { etc.) }\end{array}$ & $\begin{array}{l}\text { Enter the inches of known or possible icicle at start } \\
\text { of period (for example, January 1981) or extra } \\
\text { inches of tape added by a kink in the current tape } \\
\text { (such as observed by in-tank video) }\end{array}$ \\
\hline 46 & $\begin{array}{l}\text { Subt from Current Sfc Lvl: } \\
\text { intrusion or addition }\end{array}$ & $\begin{array}{l}\text { Enter inches of proven intrusion or addition, not } \\
\text { hypothetical or speculated. }\end{array}$ \\
\hline 47 & $\begin{array}{l}\text { Subt from Current Sfc Lvl: } \\
\text { condensation from ambient air, } \\
\text { which has dripped into tank }\end{array}$ & $\begin{array}{l}\text { Enter inches of proven condensation, not } \\
\text { hypothetical or speculated. }\end{array}$ \\
\hline 48 & $\begin{array}{l}\text { Subt from Current Sfc Lvl: } \\
\text { hygroscopic absorption }\end{array}$ & $\begin{array}{l}\text { Enter inches of proven absorption, not hypothetical } \\
\text { or speculated. }\end{array}$ \\
\hline 49 & $\begin{array}{l}\text { Subt from Current } S f c \text { Lvl: crust } \\
\text { expansion by gas }\end{array}$ & $\begin{array}{l}\text { Enter inches of proven expansion, not hypothetical } \\
\text { or speculated. }\end{array}$ \\
\hline 50 & $\begin{array}{l}\text { Subt from Current Sfc Lvl: crystal } \\
\text { expansion }\end{array}$ & $\begin{array}{l}\text { Enter inches of proven expansion (such as by } \\
\text { Ostwald ripening), not hypothetical or speculated. }\end{array}$ \\
\hline 51 & $\begin{array}{l}\text { Tank atmospheric breathing rate - } \\
\text { SSTw/oFIC (Crippen: } 0.45 \% \\
\text { natural breathing) }\end{array}$ & $\begin{array}{l}\text { Enter } 0.45 \% \text { (Crippen 1993) unless the tank can be } \\
\text { conclusively shown to breathe at a higher rate. }\end{array}$ \\
\hline 52 & $\begin{array}{l}\text { Tank FIC purge rate (nominally } 50- \\
200 \mathrm{cfh} \text { ) }\end{array}$ & $\begin{array}{l}\text { Enter } 0 \text {. Purge is not required by a safety } \\
\text { document, therefore no credit is taken for the purge. }\end{array}$ \\
\hline 53 & Tank Vent rate & See explanation for line 74 \\
\hline 54 & $\begin{array}{l}\text { Tank breathing rate: } \\
\text { SSTxFIC,SSTwFIC, or DST }\end{array}$ & $\begin{array}{l}\text { Enter SSTxFIC for SSTs to take no account of } \\
\text { purge rate. Enter DST if there is a non-zero value } \\
\text { in line } 53 \text {; entering DST causes the spreadsheet to } \\
\text { calculate steady-state concentration based on vent } \\
\text { flow rate. }\end{array}$ \\
\hline 55 & Ratio of NH3 to H2 (normally 4) & $\begin{array}{l}\text { Enter } 4 \text { as the bounding } \mathrm{NH}_{3} / \mathrm{H}_{2} \text { ratio in steady-state } \\
\text { headspace air unless shown otherwise by sampling. } \\
\text { If sample values were entered in lines } 33 \text { and } 34 \text {, } \\
\text { spreadsheet disregards value entered here. }\end{array}$ \\
\hline
\end{tabular}


Table C-2. Instructions for Filling in the Excelim Spreadsheet ( 9 sheets).

\begin{tabular}{|c|c|c|}
\hline Line & Description & Instruction/Comment/Explanation \\
\hline 56 & $\begin{array}{l}\text { Ratio of } \mathrm{CH} 4 \text { to } \mathrm{H} 2 \text { (normally } \\
0.020 \text { ) }\end{array}$ & Enter 0.020 \\
\hline 57 & $\begin{array}{l}\text { Assume } \mathrm{NH} 3 \mathrm{vol}=\text { this fraction of } \\
\text { slurry gas released (normally } \\
0.220 \text { ) }\end{array}$ & $\begin{array}{l}\text { Per Hopkins (1994), in SY-101, in which trapped } \\
\text { gas is } \sim 30 \% \mathrm{H}_{2} \text { and a few percent } \mathrm{NH}_{3} \text {, this } \\
\text { fraction is } 0.259 \text {. In the current evaluation, trapped } \\
\text { gas is assumed to be } 97 \% \mathrm{H}_{2} \text { and } 0 \% \mathrm{NH}_{3} \text {; } \\
\text { therefore, } \mathrm{NH}_{3} \text { is assumed to be decreased to } \\
0.220 \text {. }\end{array}$ \\
\hline 58 & $\begin{array}{l}\text { Assume CH4 vol = this fraction of } \\
\text { trapped gas released (normally } 0.00 \\
\text { per Hopkins) }\end{array}$ & $\begin{array}{l}\text { Per Hopkins, fraction is } 0.02 \text { in tanks like SY-101, } \\
\text { in which } \mathrm{H} 2 \text { is about } 30 \% \text { of trapped gas. } \\
\text { However, in this case, the trapped gas is } 97 \% \mathrm{H}_{2} \\
\text { and } 3 \% \text { water vapor, with no room for } \mathrm{CH}_{4} \text {, so } \\
\text { enter } 0 \text {. }\end{array}$ \\
\hline 59 & $\begin{array}{l}\text { Select Confidence Level for } \\
\text { Barometric Pressure/Surface Level } \\
\text { Correlation }\end{array}$ & Normally, enter $75 \%$. \\
\hline 60 & Slope at $95 \%$ confidence & $\begin{array}{l}\text { Enter value of slope from Whitney, including } \\
\text { negative sign. }\end{array}$ \\
\hline 61 & Slope at $75 \%$ confidence & $\begin{array}{l}\text { Enter value of slope from Whitney, including } \\
\text { negative sign }\end{array}$ \\
\hline 62 & Slope at $50 \%$ confidence & $\begin{array}{l}\text { Enter value of slope from Whitney, including } \\
\text { negative sign }\end{array}$ \\
\hline 63 & QFit Mean & Enter value from plots obtained from Whitney. \\
\hline 64 & QFit Standard Deviation & Enter value from plots obtained from Whitney. \\
\hline
\end{tabular}


Table C-2. Instructions for Filling in the Excelm Spreadsheet (9 sheets).

\begin{tabular}{|l|l|l|}
\hline Line & Description & Instruction/Comment/Explanation \\
\hline
\end{tabular}

\begin{tabular}{|c|c|c|c|c|}
\hline \multirow[t]{6}{*}{65} & \multirow[t]{6}{*}{$\begin{array}{l}\text { Engineer Selects Surface Rise } \\
\text { Method: L (Liquids) or S (Solids) }\end{array}$} & \multicolumn{3}{|c|}{$\begin{array}{l}\text { Line } 65 \text { tell Excel } \\
66 \text { tells Excel how to calculate SL rise. Line } \\
\text { porosity of the solids when to take into account the } \\
\text { based on surface level rise and barometric slope. } \\
\text { The table below tells what entries to make in these } \\
\text { two lines and whether Excel } \\
\text { based on the entry in line } 66 \text {. }\end{array}$} \\
\hline & & $\begin{array}{c}\text { SL Rise } \\
\text { Is Based on } \\
\Delta \text { Level in } \\
\end{array}$ & $\begin{array}{l}\text { Line } 65 \\
\text { Enter }\end{array}$ & $\begin{array}{l}\text { Line } 66 \\
\text { Adjusts for } \\
\text { Enter Porosity }\end{array}$ \\
\hline & & Supernate Layer & & SUP $\quad$ No \\
\hline & & Supernate in Hole & $\mathbf{L}$ & LIH \\
\hline & & IILL & L & LIH \\
\hline & & Solids & $S$ & SOL \\
\hline 66 & $\begin{array}{l}\text { Engineer Identifies Level } \\
\text { Measurement Condition: SUP, } \\
\text { SOL, LIH }\end{array}$ & \multirow{3}{*}{\multicolumn{3}{|c|}{$\begin{array}{l}\text { In general, for a tank which has (1) a liquid surface } \\
\text { level (SL) measured below the solids surface via } \\
\text { FIC/ENRAF/MT in a hole or small pool, and (2) } \\
\text { an ILL reading, the supernate readings should be } \\
\text { more reliable than the IIL. Therefore, calculate the } \\
\text { SL rise based on } \Delta \mathrm{L} \text { in supernate in a hole: enter } \\
\text { LIH for liquid in hole. } \\
\text { Generally, ILL is measured via a neutron probe in } \\
\text { a liquid observation well (LOW) in a hole sluiced } \\
\text { into the waste, so LIH (liquid in hole) is the } \\
\text { appropriate entry in line } 66 \text {. } \\
\text { For a tank with supernate level and submerged- } \\
\text { solids level measurements for the beginning and } \\
\text { end of the evaluation period, in general, calculate } \\
\text { the SL rise based on } \Delta L \text { in Solids, since solids } \\
\text { gives a direct measure of the gas growth during the } \\
\text { period. }\end{array}$}} \\
\hline & & & & \\
\hline & & & & \\
\hline 67 & $\begin{array}{l}\text { Temperature of Entering Air. If } \\
\text { unknown, enter } 56.3 \mathrm{~F} \text { (Year Avg). }\end{array}$ & \multicolumn{3}{|c|}{$\begin{array}{l}\text { Unless known otherwise, enter year-round average } \\
\text { of } 56.3^{\circ} \mathrm{F} \text {. }\end{array}$} \\
\hline 68 & $\begin{array}{l}\text { Relative Humidity of Entering Air. } \\
\text { If unknown, enter } 50 \%\end{array}$ & \multicolumn{3}{|c|}{$\begin{array}{l}\text { If psychrometric data show actual humidity, enter } \\
\text { that RH. Otherwise, enter } 50 \% \text {. }\end{array}$} \\
\hline 69 & $\begin{array}{l}\text { Temperature of Vapor in Dome } \\
\text { Space (Year Ave) }\end{array}$ & \multicolumn{3}{|c|}{$\begin{array}{l}\text { For the period during which evaporation occurred, } \\
\text { obtain from PC-SACS or best source,. . If not } \\
\text { available, estimate conservatively (higher is more } \\
\text { conservative). }\end{array}$} \\
\hline 70 & $\begin{array}{l}\text { Relative Humidity of Exiting Air. } \\
\text { If unknown, enter } 100 \% \text {. }\end{array}$ & \multicolumn{3}{|c|}{$\begin{array}{l}\text { If psychrometric data are available and actual } \\
\text { relative humidity (RH) is therefore known, enter } \\
\text { that RH. Otherwise enter } 100 \% \text {. }\end{array}$} \\
\hline
\end{tabular}


Table C-2. Instructions for Filling in the Excelm Spreadsheet (9 sheets).

\begin{tabular}{|c|c|c|}
\hline Line & Description & Instruction/Comment/Explanation \\
\hline 71 & $\begin{array}{l}\text { Surface Temperature of Waste } \\
\text { (Year Ave) }\end{array}$ & $\begin{array}{l}\text { Obtain from PC-SACS, or best source, for the } \\
\text { period during which evaporation occurred. If not } \\
\text { available, estimate conservatively (higher is more } \\
\text { conservative). }\end{array}$ \\
\hline 72 & $\begin{array}{l}\text { Enter Period of Time over which } \\
\text { evaporation occurs }\end{array}$ & $\begin{array}{l}\text { For the time period during which surface level rise } \\
\text { is estimated, enter the number of years (for } \\
\text { example, } 6.5 \text { ) when tank had exposed liquid } \\
\text { surface. }\end{array}$ \\
\hline 73 & $\begin{array}{l}\text { Enter Fraction of Heat Load used in } \\
\text { calculating Vent Rate. If unknown, } \\
\text { enter } 50 \% \text {. }\end{array}$ & $\begin{array}{l}\text { If heat-load modeling has been done for the tank, } \\
\text { enter fraction from that work. Otherwise, enter } \\
50 \% \text {. }\end{array}$ \\
\hline 74 & $\begin{array}{l}\text { Enter Calculation Result to Report } \\
\text { on lines } 123 \text { and } 124 \text { (continued on } \\
\text { next page) }\end{array}$ & $\begin{array}{l}\text { Excel }^{\mathrm{TM}} \text { always calculates evaporation three ways: } \\
\text { 1. HL: Based on line } 73 \text {, fraction of heat load } \\
\text { (HL) driving evaporation, determines the } \\
\text { evaporation rate and resulting surface level drop } \\
\text { during the evaluation period (line } 74 \text { ). } \\
\text { 2. INP: Based on the entering air's temperature } \\
\text { and RH (lines } 67 \text { and } 68 \text { ), calculates the mass } \\
\text { of water in the air. Likewise, Excel }{ }^{\mathrm{TM}} \text { uses the } \\
\text { exiting air's temperature and RH (lines } 69 \text { and } \\
\text { 70) to calculate the mass in exiting air. The } \\
\text { increase is the evaporated water the exiting air } \\
\text { removes from the tank. ExcelTM uses the input } \\
\text { (INP) vent rate (line } 53 \text { ) to determine the } \\
\text { amount of water removed, and the surface level } \\
\text { drop, during the evaluation period (line } 74 \text { ). } \\
\text { 3. SAM: Calculates H2 generation rate and the } \\
\text { vent rate that would result in the concentration } \\
\text { of H }{ }_{2} \text { determined by sampling (SAM) (line } 33 \text { ). } \\
\text { Then, as described above for INP, Excel }{ }^{\mathrm{TM}} \text { uses } \\
\text { that flow rate to determine the amount of water } \\
\text { removed, and the surface level drop, during the } \\
\text { evaluation period. Because the calculated } \mathrm{H}_{2} \\
\text { generation rate is sometimes very conservative, } \\
\text { the level drop calculated using this rate can be } \\
\text { very conservative. } \\
\text { (continued on next page) }\end{array}$ \\
\hline
\end{tabular}


Table C-2. Instructions for Filling in the Excel ${ }^{\text {rm }}$ Spreadsheet ( 9 sheets).

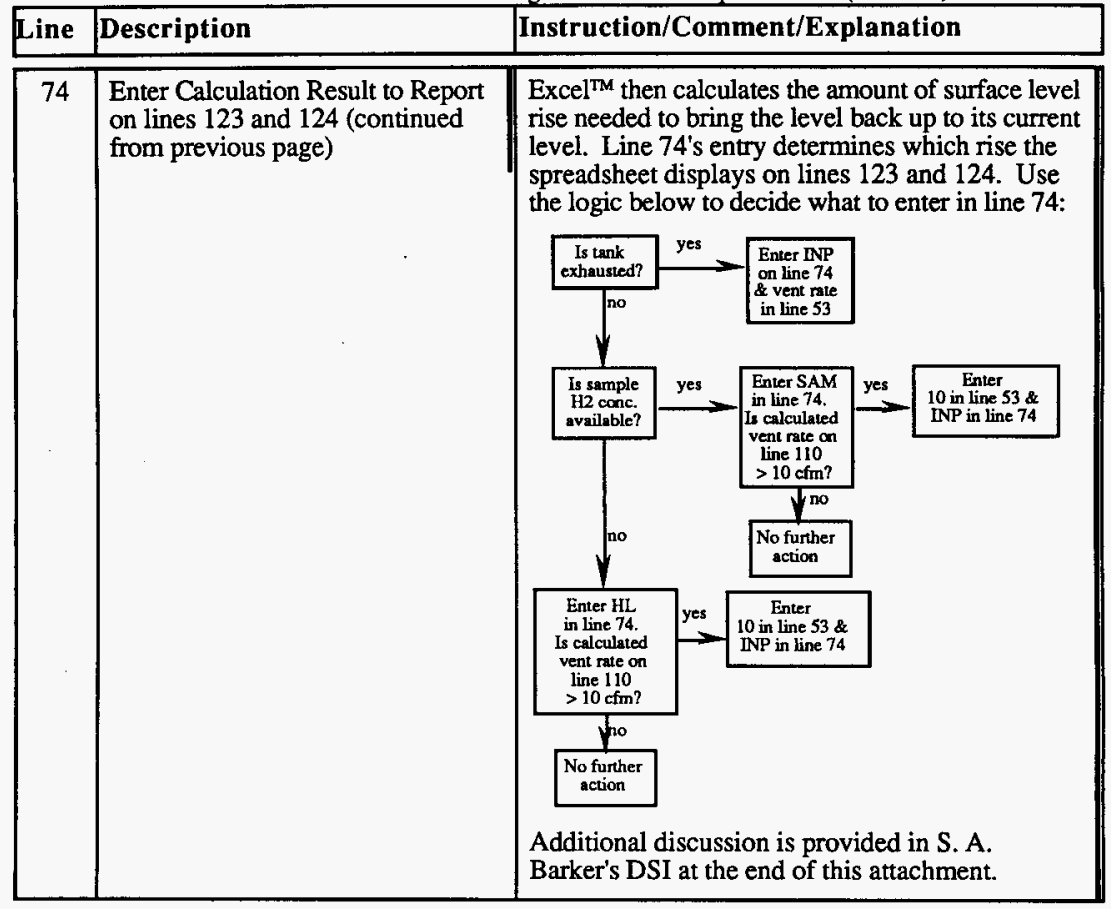


Results of Calculations of Entrapped Gas Volume and \% LFL Based on Surface Level Rise

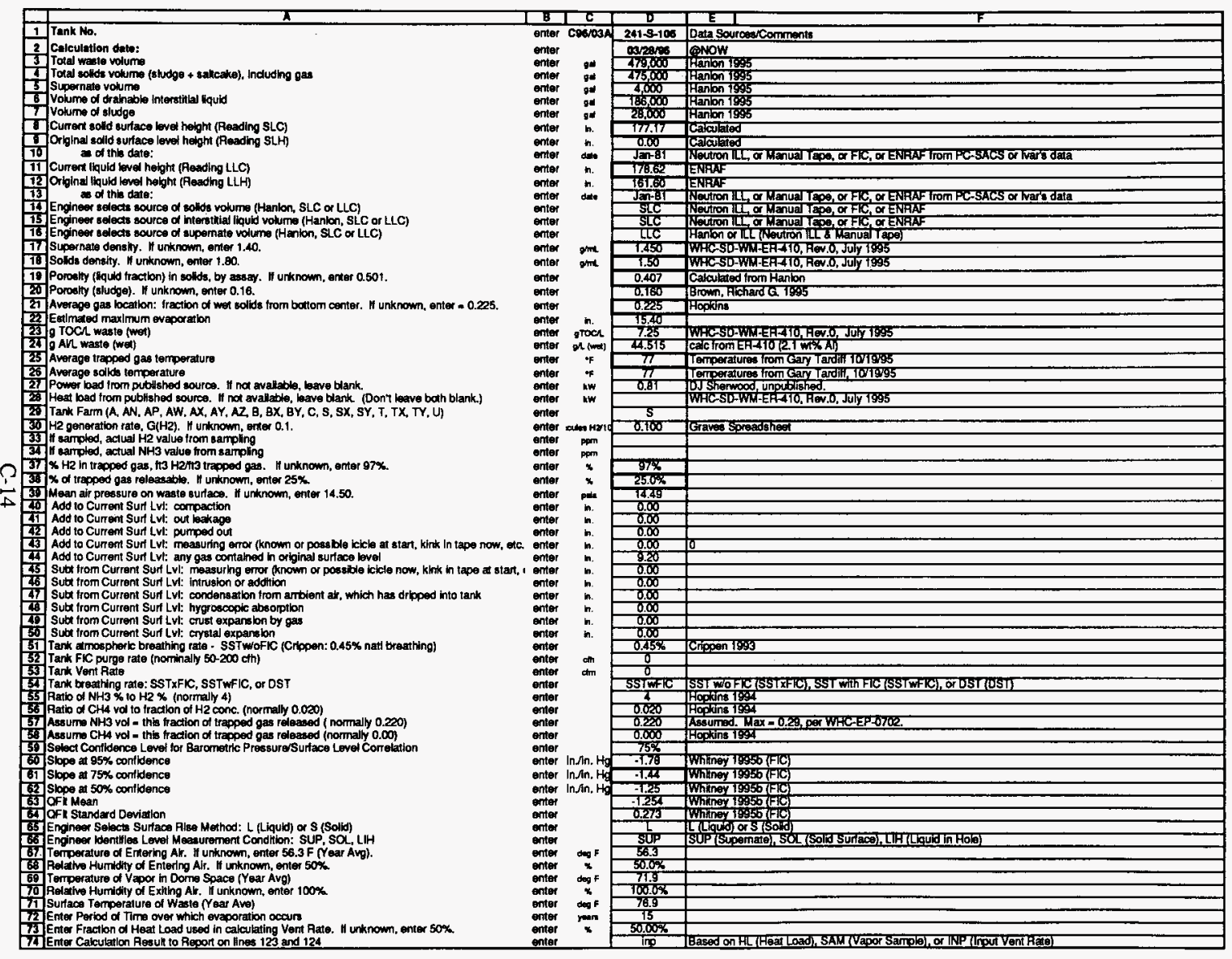




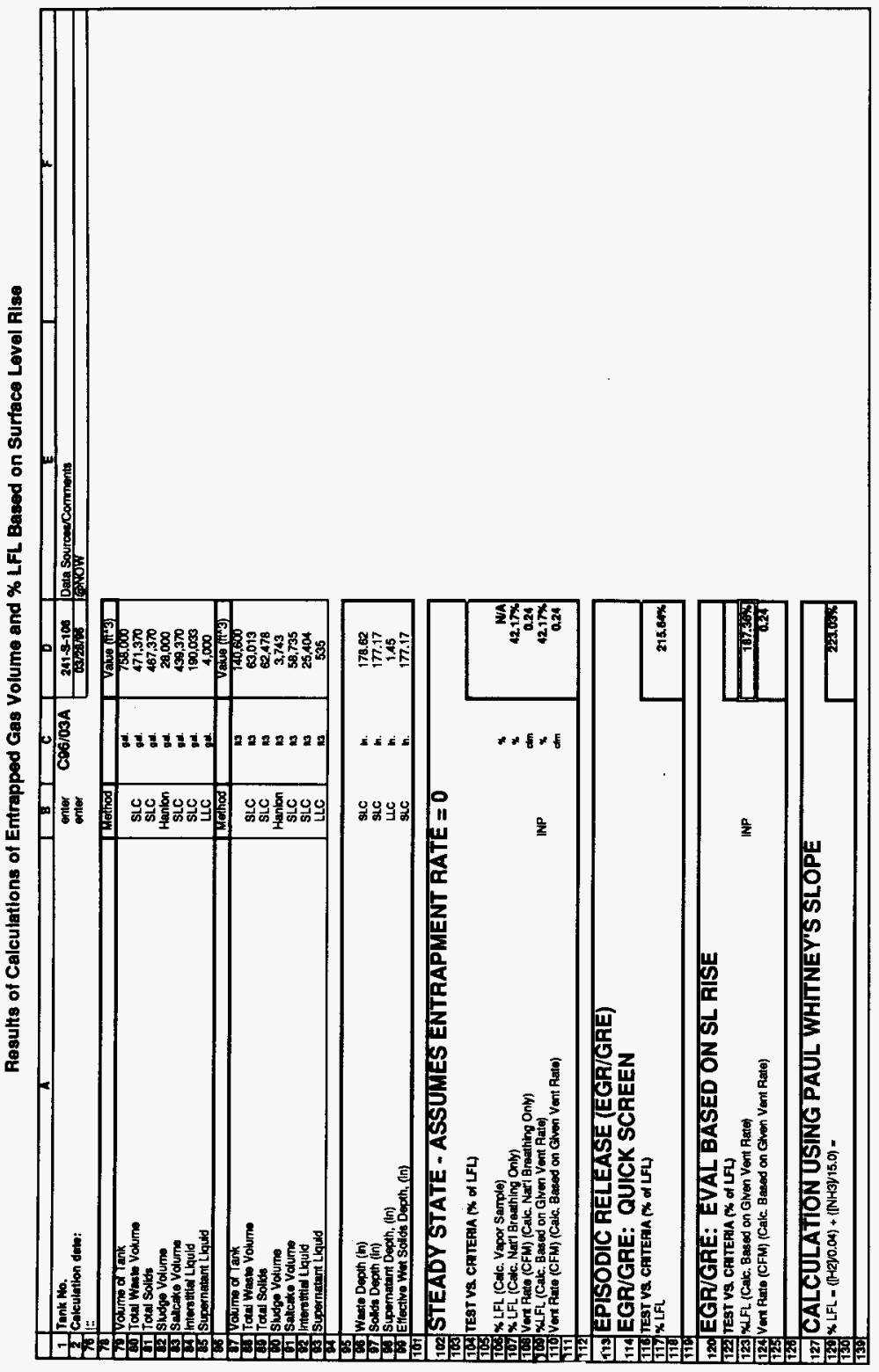


Results of Calculations of Entrapped Ges Volume and \% LFL Based on Surface Level Rise

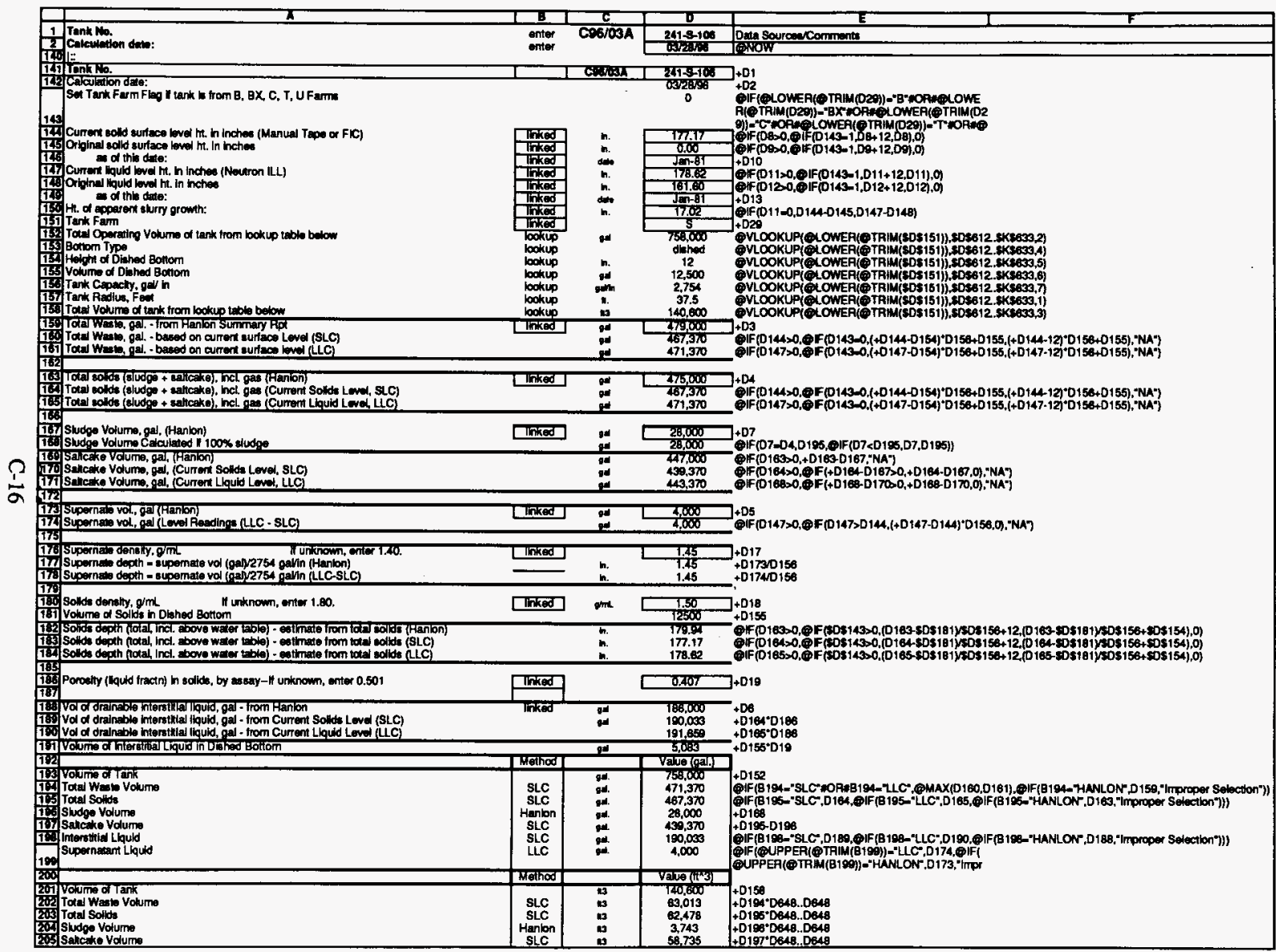


Results of Calculations of Entrapped Gas Volume and \% LFL Based on Surtace Level Rise

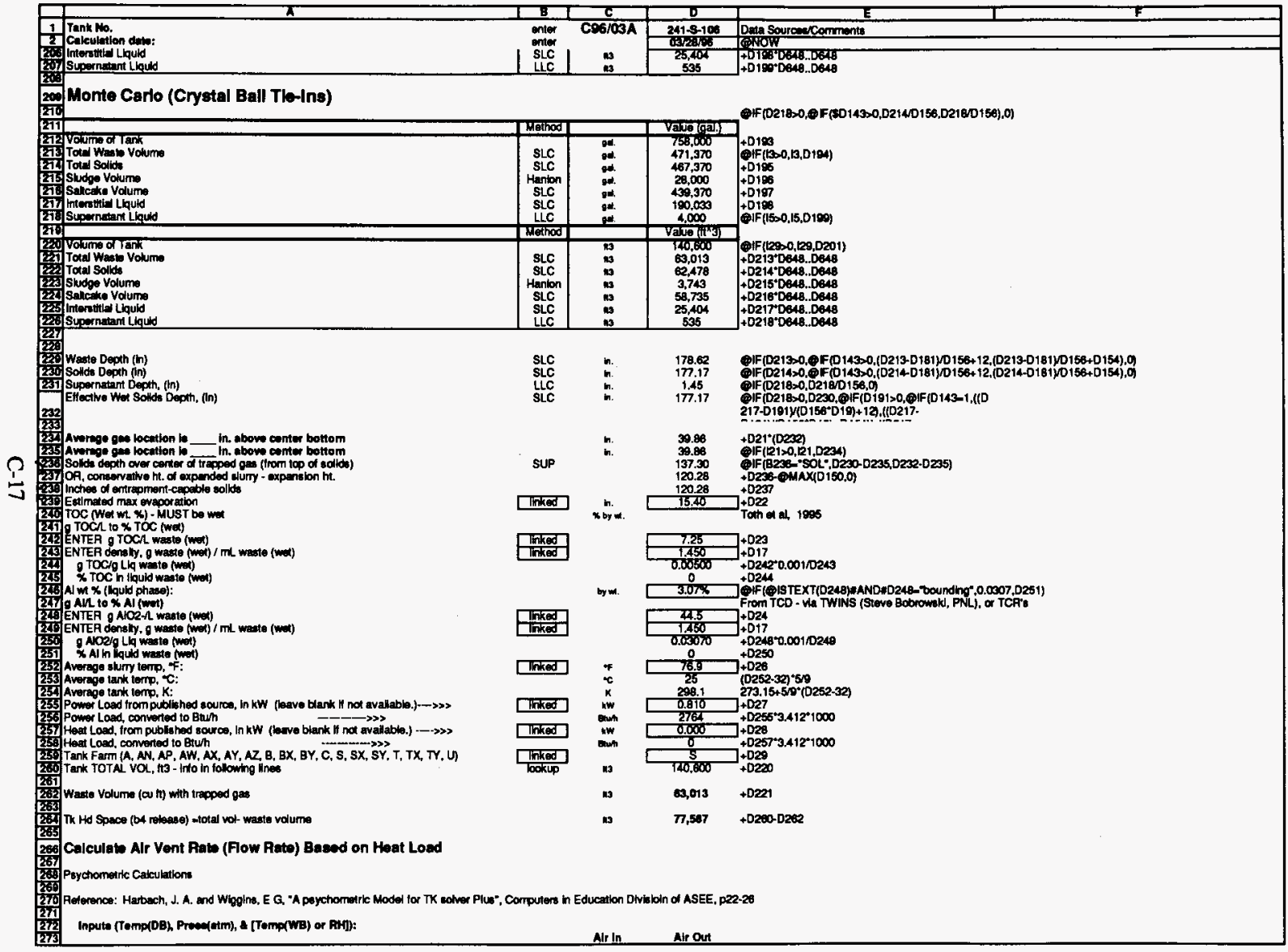


Results of Calculations of Entrapped Gas Volume and \% LFL Based on Surface Level Rise

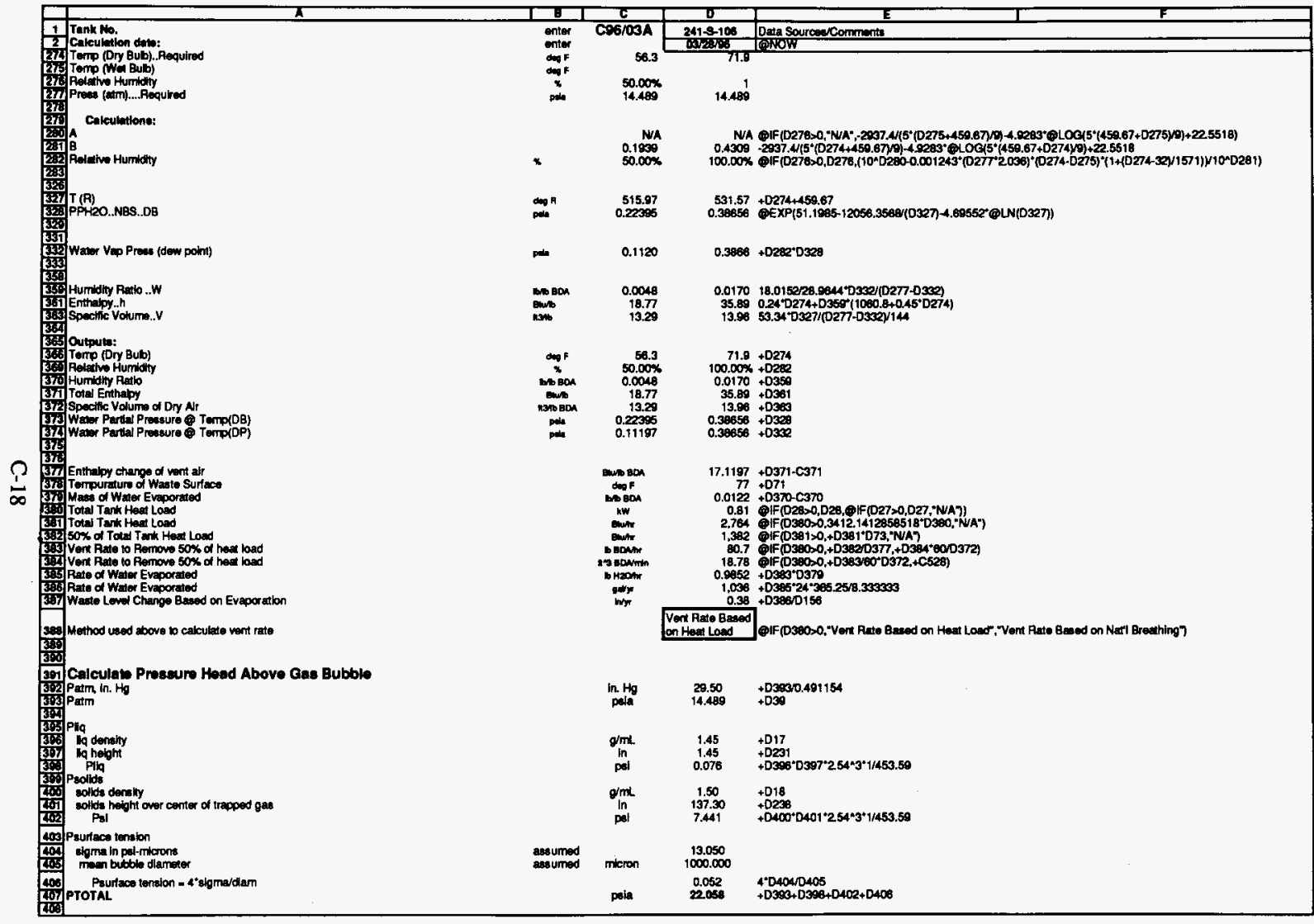


Results of Calculatlons of Entrapped Gas Volume and \% LFL Based on Surface Level Rise

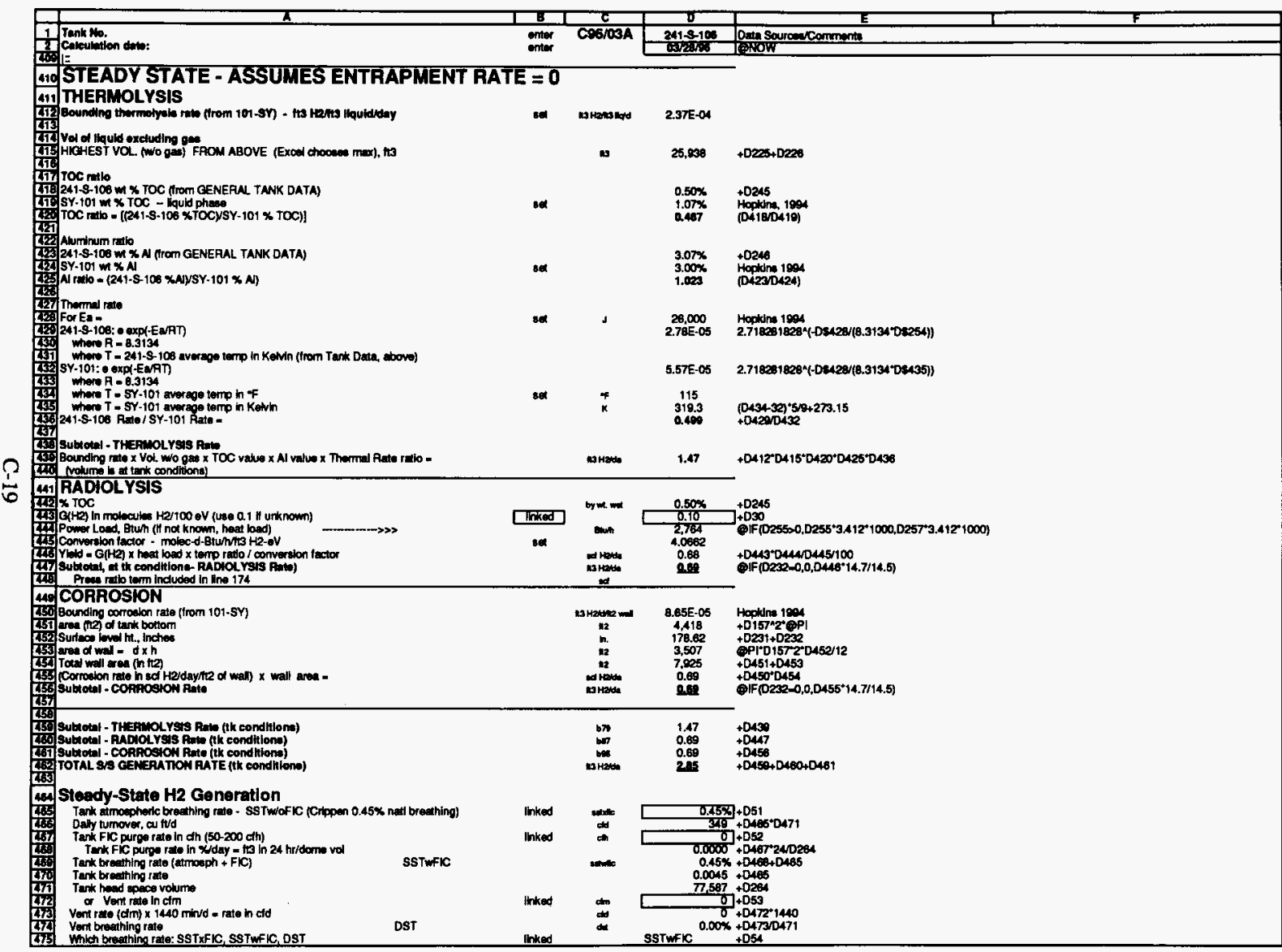


Results of Calculations of Entrapped Gas Volume and \% LFL Based on Surface Level Rise

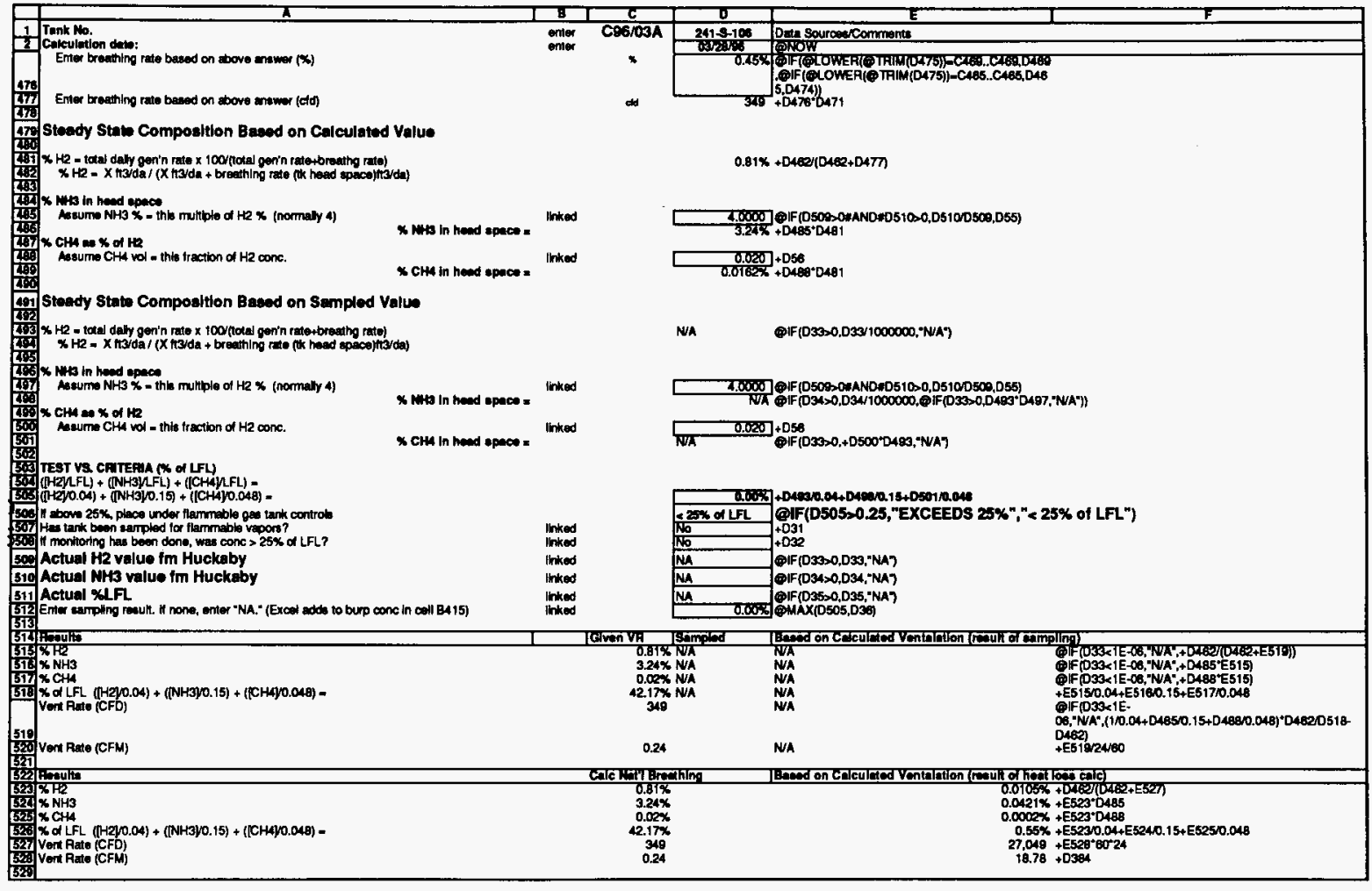


Results of Calculations of Entrapped Gas Volume and \% LFL Based on Surface Level Rise

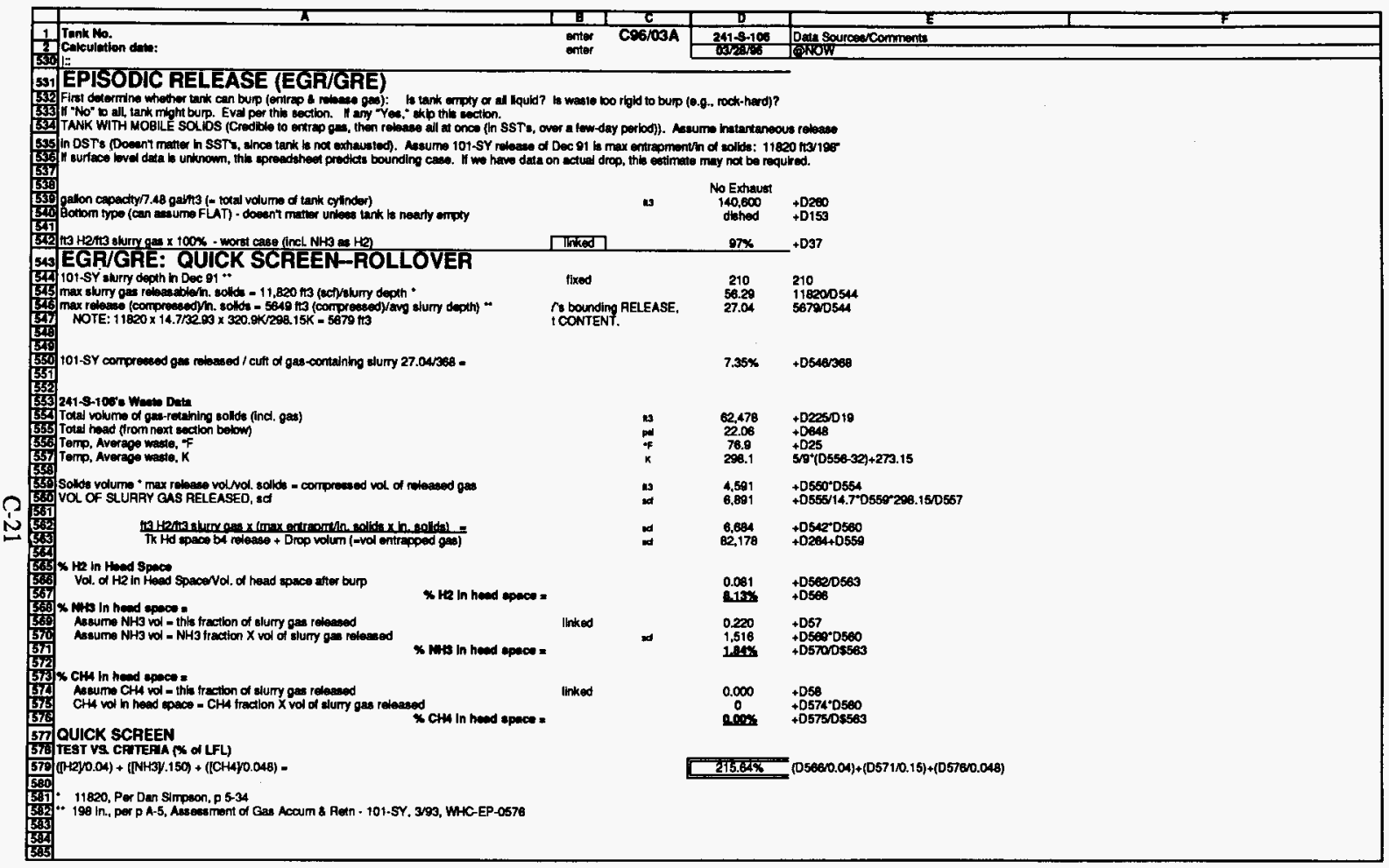


Results of Calculatlons of Entrapped Gas Volume and \% LFL Based on Surtace Level Rlse

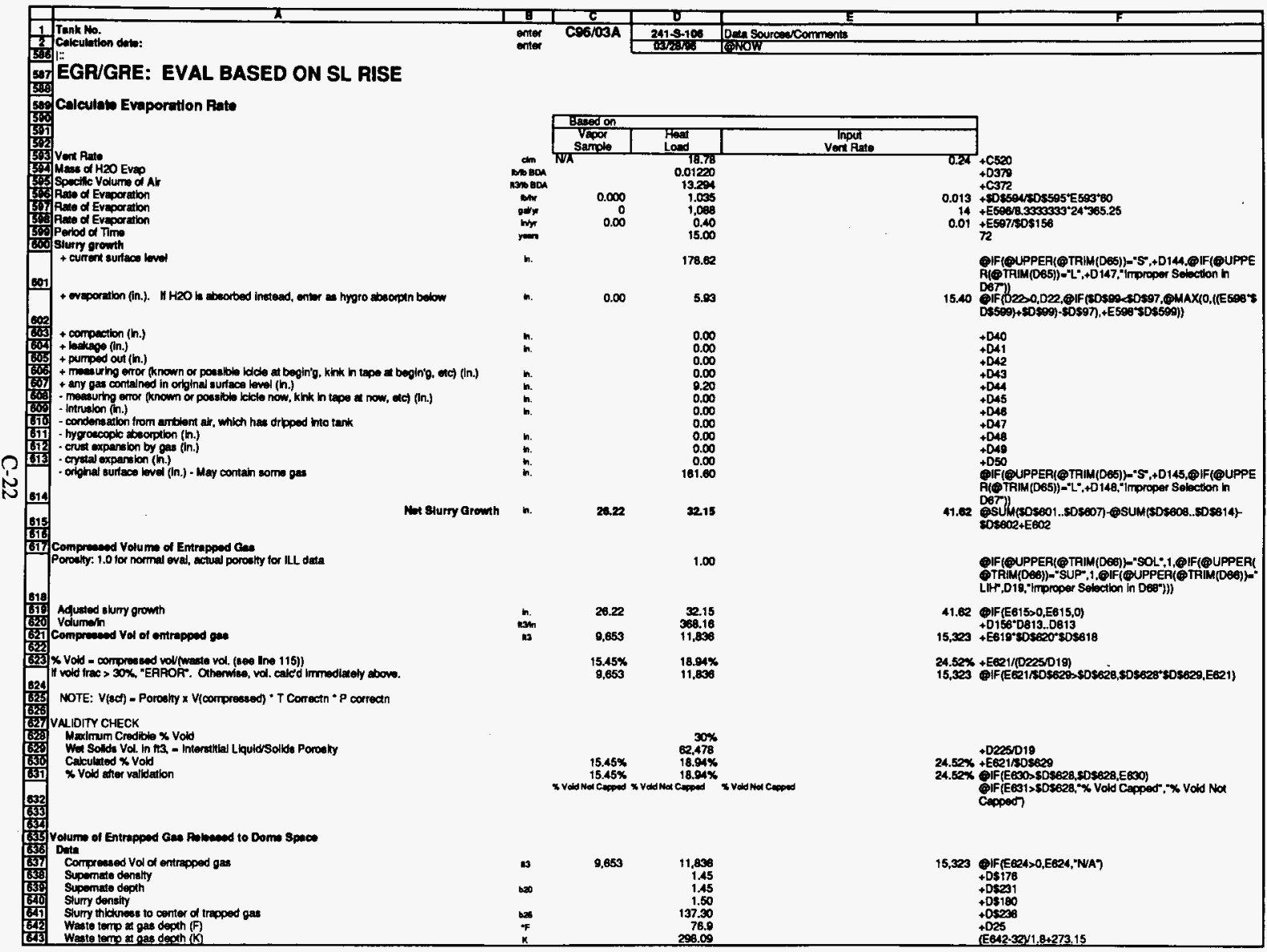


Results of Calculations of Entrapped Gas Volume and \% LFL Based on Surface Level Rise

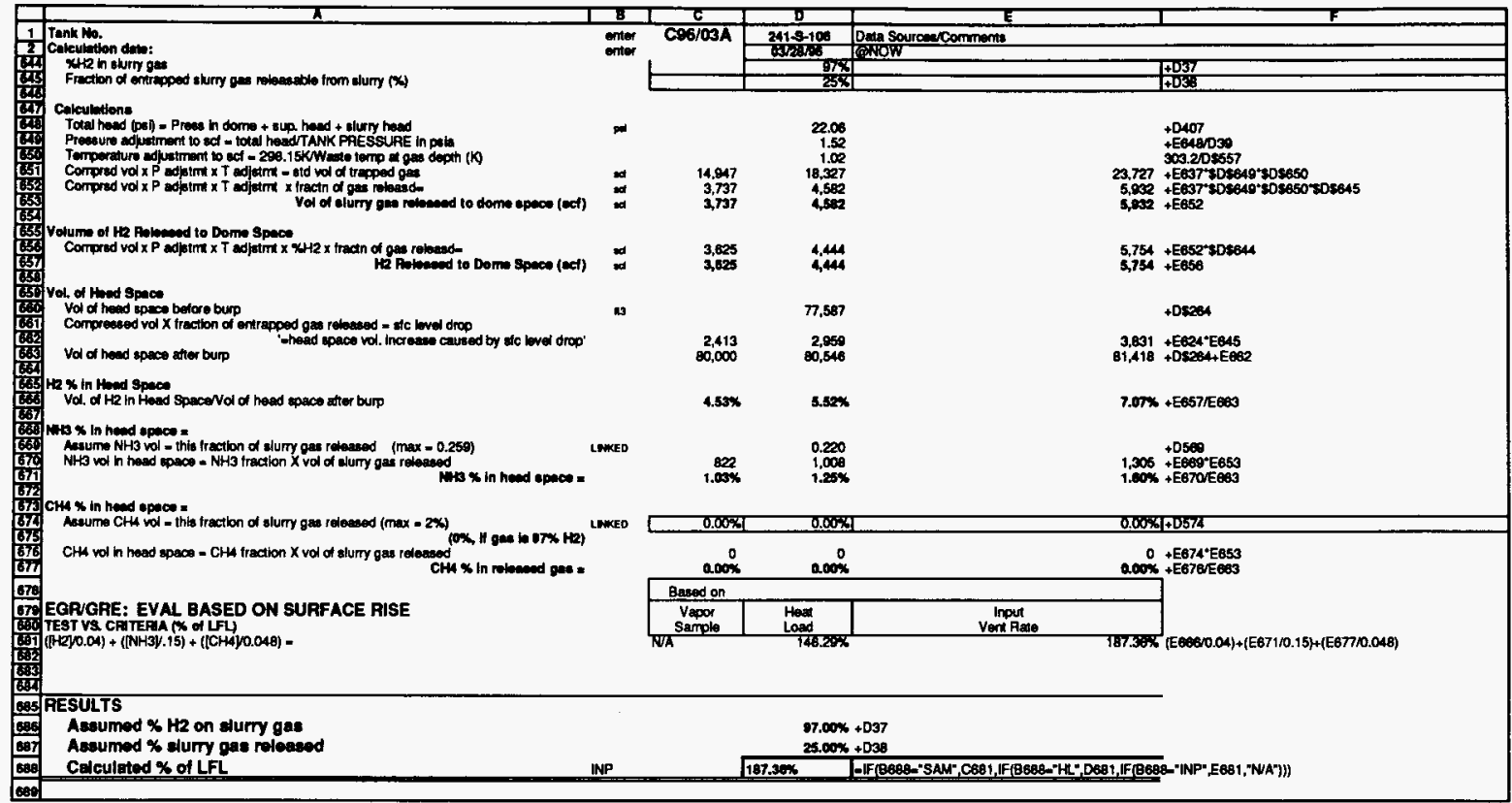


Results of Calculations of Entrapped Gas Volume and \% LFL Based on Surface Level Rlse

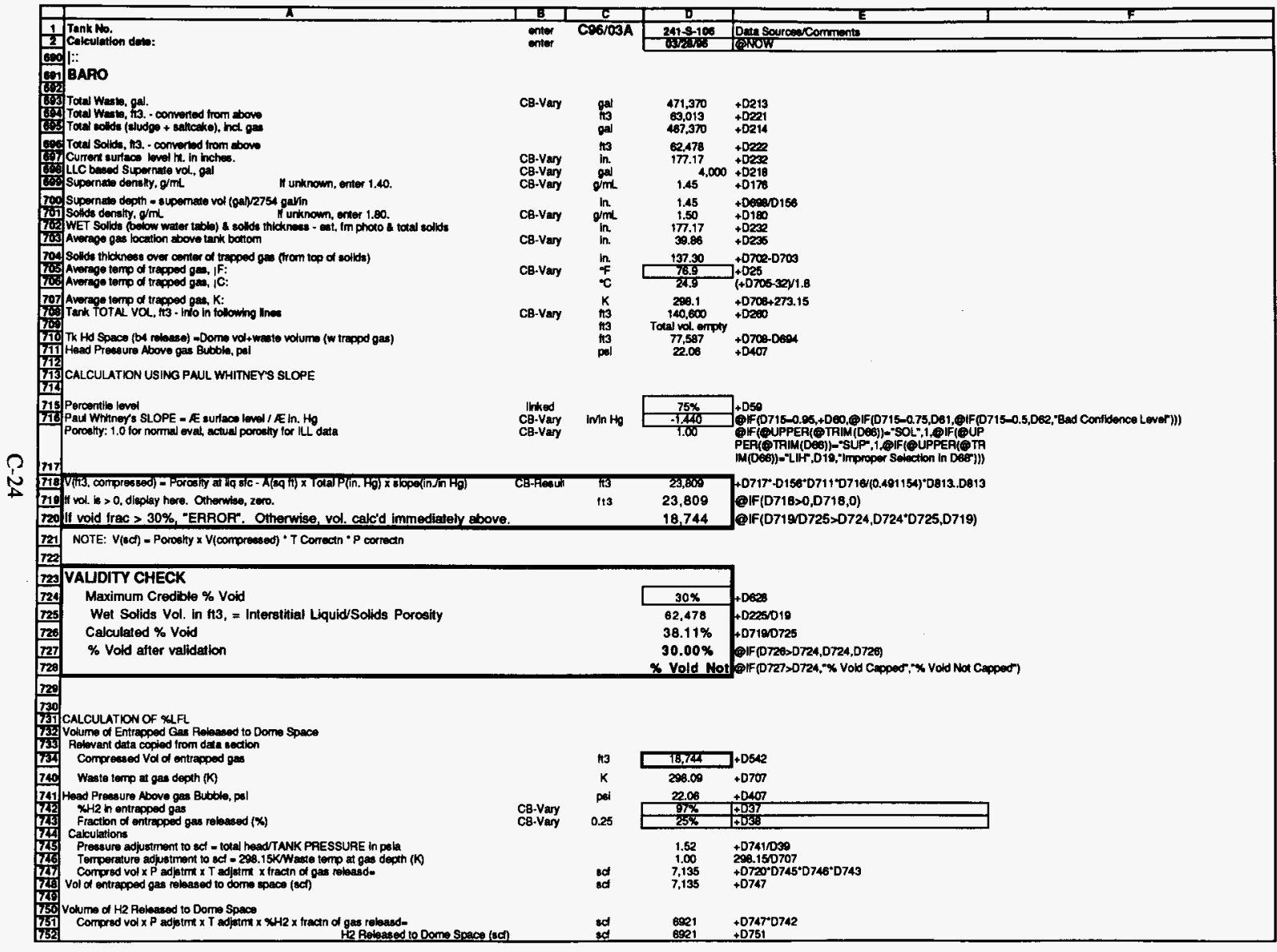


Resulhs of Calculations of Entrapped Gas Volume and \% LFL Based on Surface Level Rise

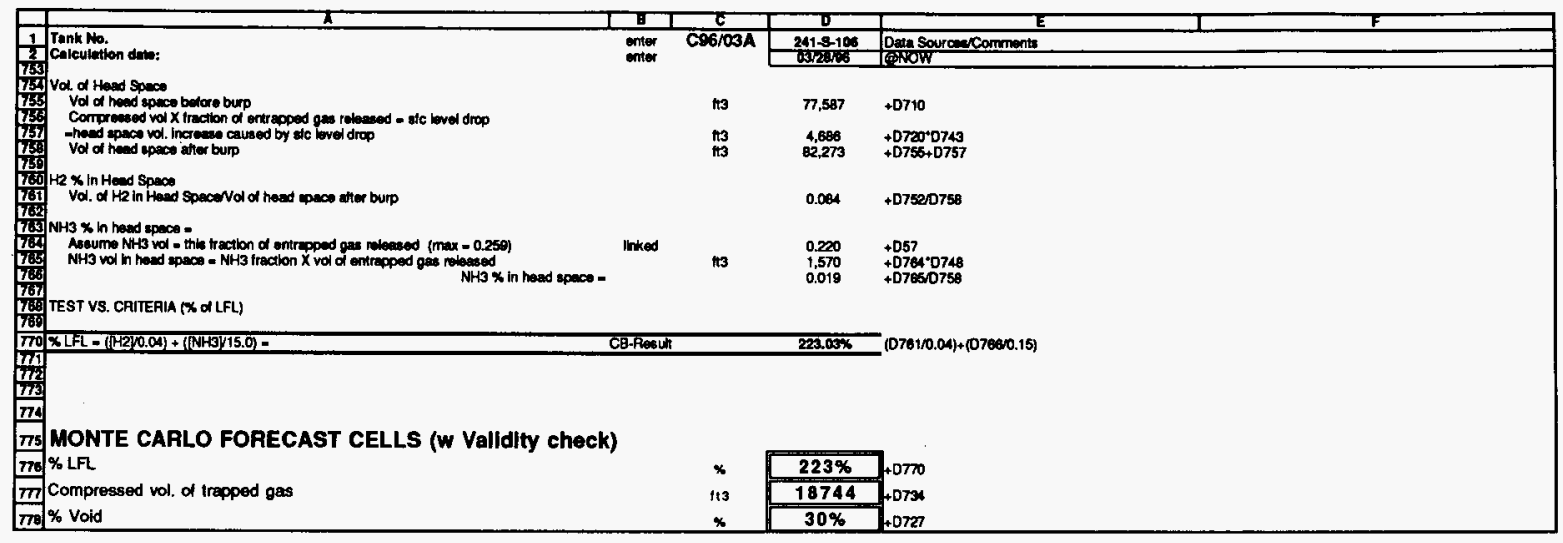

in 
Results of Calculations of Entrapped Gas Volume and \% LFL Based on Surface Level Rise

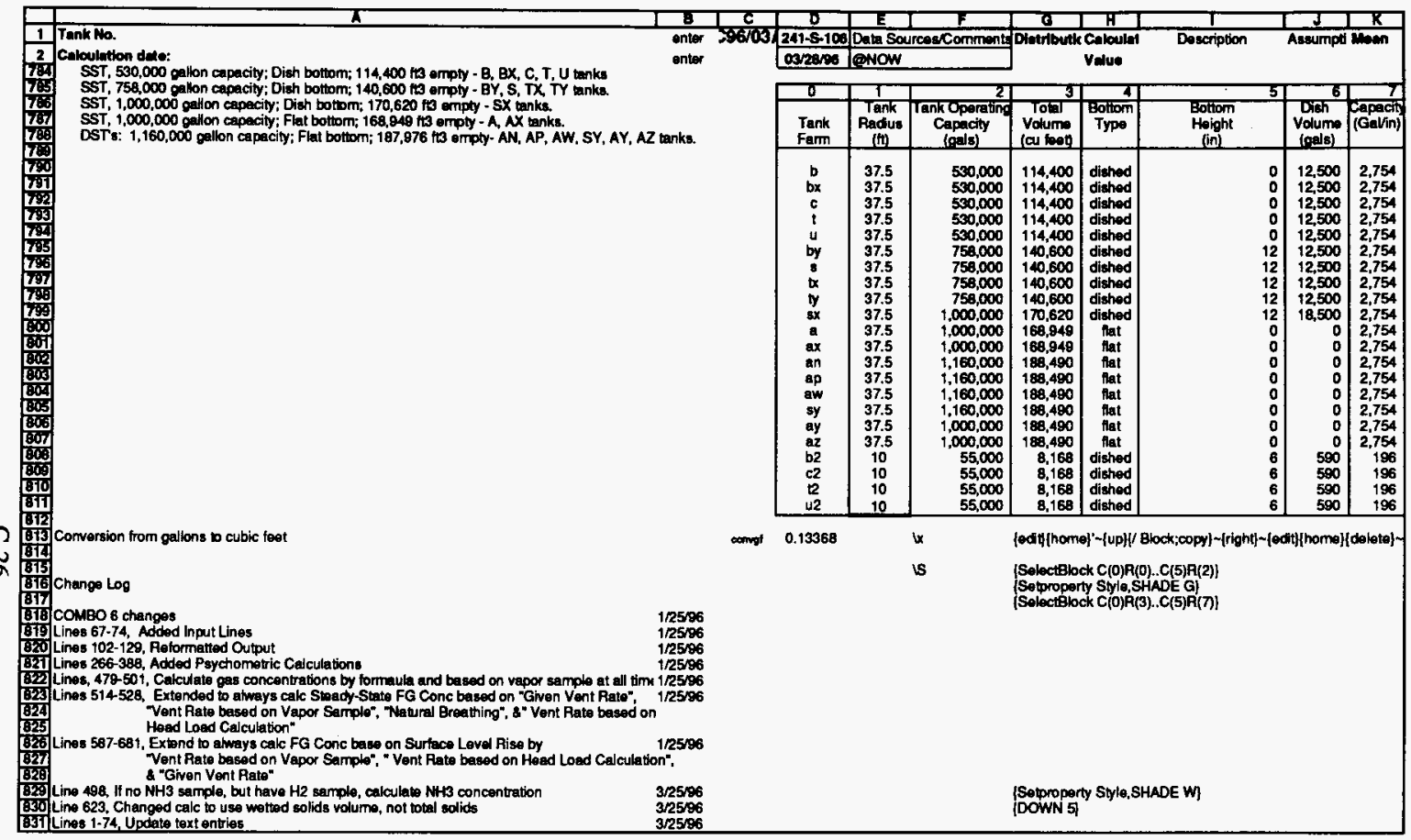


Results of Calculations of Entrapped Gas Volume and \% LFL Based on Surface Level Rise

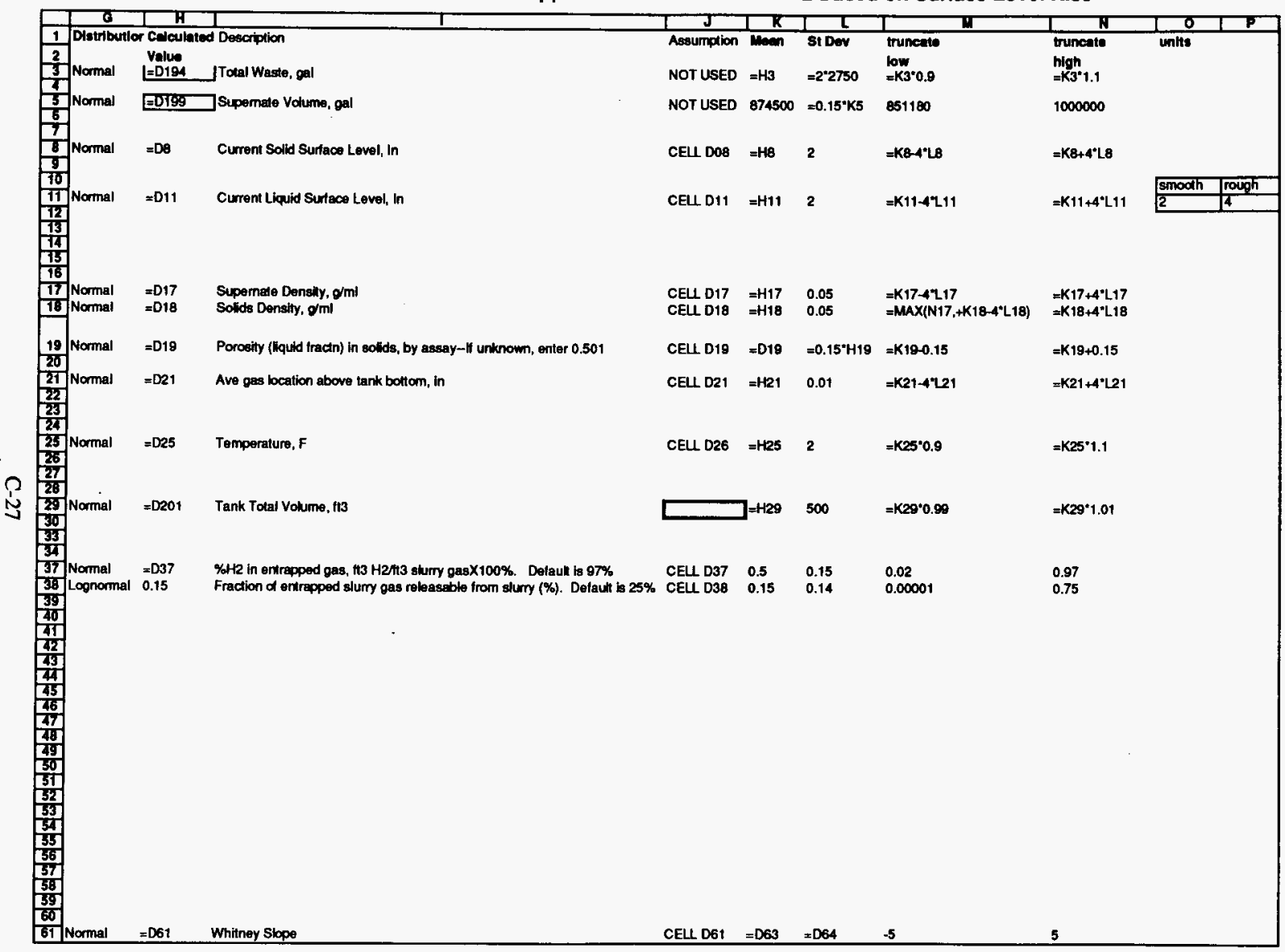


DON'T SAY IT -- Write $\| !$

TO: Davethokins

SUBJECT: Implications of Vent Rate and Evaporation In the Flammable Gas Evaluation. January through March 1996

\subsection{Summary}

In response to peer review comments in December 1995, the model for the evaluation of tanks against the Flammable Gas Watch-List Criteria was modified to include the effect of evaporation on surface level rise. In the November 1995 version of the Exce|m spreadsheet, the engineer could enter evaporation amounts expressed in inches of tank level (about 2,750 gallons per inch for 100 series tanks). The modifications allow the Excel $\mathrm{TM}$ spreadsheet to calculate the steady-

state flammable gas concentration using a tank ventilation rate corresponding to:

- the natural breathing rate $(0.45$ volume $\%$ per day),

- a natural convection rate,

- the forced ventilation rate,

- a ventilation rate based on removal of $50 \%$ (user selectable) of the tank heat load, and

- a ventilation rate calculated based on the comparison between the calculated steady-

state flammable gas concentration and a sample result flammable gas composition.

These ventilation rates are utilized to calculate tank evaporation rates, which are then incorporated into the calculation of surface level rise and volume of trapped gas. The effect and methodology as related to the calculation of the steady-state flammable gas concentration and the surface-level rise release event flammable gas concentration are presented.

\subsection{Vent Rate Calculations}

The Flammable Gas Evaluation (FGE) establishes its ventilation and evaporation calculations on several different bases. In all evaluations, the program calculates ventilation rates based on the 4 methods discussed in this section. The evaluator inputs some basic information, but generally due to lack of data, assumed values are used.

\subsection{Vent rate calculation based on natural breathing}

The ventilation rate based on natural breathing is always calculated by the spreadsheet and reported in the results section of the model. In most of the single-shell tanks (SST), the sole source of tank ventilation is natural breathing. In tanks with forced exhausters, the natural breathing rate would be the tank ventilation rate if power were lost to the ventilation blowers and if there is no natural convection. This ventilation reflects the movement of air into and out of the tank as the outside air temperature and barometric pressure change. Crippen (1993) reported that averaged over the temperature cycles for the full day and the full year, the natural breathing rate is 0.45 volume $\%$ of the tank vapor space per day. This ventilation rate gives a very conservative value for the tank steady-state flammable gas concentration. In addition, this ventilation rate will give a very small evaporation rate, which results in a non-conservative flammable gas concentration based on the surface level rise evaluation.

Input data: Natural Breathing Rate in percent of vapor space volume per day (assumed value of $0.45 \%$ of the tank vapor space per day). 


\subsection{Vent rate calculation based on input ventilation rate}

This is the tank's ventilation rate based on forced ventilation or natural convection. The source of ventilation may be through Food Instrument Corporation Level Measurement Device (FIC) instrument air, or may be exhauster fans. In non-forced ventilation tanks, temperature differences between tanks and the atmosphere may cause natural convection to occur. Sadasivan (1995) reports flow rates up to $10 \mathrm{cfm}$ for high temperature tanks based on his modeling efforts. Flow rates for natural convection may be input (line 53), but usually this amount is only input if vapor sample data supports the presence of significant natural convection flow rates. A flow rate is then input only if the natural convection flow rate based on vapor sample analysis or heat load analysis is greater than $10 \mathrm{cfm}$.

Input data: Ventilation rate through Food Instnument Corporation Level Measurement Device (FIC). This value is expressed in cubic feet per hour.

Ventilation rate through forced ventilation or natural convection. This value is expressed in cubic feet per minute.

\subsection{Vent rate calculation based on sampled value}

If a vapor sample is available, a flammable gas concentration is calculated by the ExcelTsspreadsheet in terms of the lower flammability limit. This value is then compared to the calculated value for the steadystate flammable gas concentration. A tank ventilation rate is then calculated which would produce the vapor sample concentration in the head space if the waste generated hydrogen at the calculated generation rate. This calculation assumes that the tank hydrogen generation rate is correct. As a result, ventilation rates based on the vapor sample may be very large (and unrealistic). A "natural convection" flow rate limit of $10 \mathrm{cfm}$ may be used to override the rate based on the vapor sample.

Input data: Results of vapor space sampling in ppm hydrogen and ppm ammonia.

\subsection{Vent rate calculation based on heat load}

For tanks without a vapor sample and without forced ventilation, an alternate method of calculating ventilation rate is used. A ventilation rate can be calculated using $50 \%$ of the calculated heat load for the tank. Built in psychometric relationships determine the flow rate. Once again, a "natural convection" flow rate limit of $10 \mathrm{cfm}$ may be used to override the ventilation rate based on the heat load.

Input data: Tank heat load in kilowatts. An alternate value is power load in kilowatts.

Percent of heat load to be removed by evaporation and heating of ventilation air (assumed value is $50 \%$ ).

Temperature (assumed value is $56.3^{\circ} \mathrm{F}$ ) and relative humidity of the inlet air (assumed value is $50 \%$ ).

Temperature (tank thermocouple reading or waste surface temperature minus $5^{\circ} \mathrm{F}$ ) and relative humidity of the outlet air (assumed value is $100 \%$ ).

\subsection{Steady-State Calculation}

A steady-state flammable gas concentration value is calculated. This value is a measure of the generation rate for the flammable gas components (primarily hydrogen). This calculation assumes that the flammable 
gases are not trapped within the waste solids, but are continuously released to the tank dome vapor space. When the steady-state flammable gas concentration is compared to vapor analysis results, a ventilation rate (or error in hydrogen generation rate) can be estimated. Other than being used to help calculate a ventilation rate for tanks without forced exhaust, this calculation is of little value. Sampled vapor concentrations are very low and do not approach the tank failure criteria of greater than $25 \%$ of the lower flammability limit (LFL). For the engineer's evaluation, steady-state flammable gas concentrations are always calculated based on a vapor sample (if available), a natural breathing rate (with assumed hydrogen generation rate), or a given ventilation rate (forced exhaust or natural convection).

\subsection{Surface Level Rise Prediction for a Flammable Gas Release Event}

This calculation uses changes in measured waste surface level over time to determine the quantity of flammable gases trapped within the waste matrix. It is assumed that periodically, this trapped gas can be released into the vapor space causing a hazardous condition. The spreadsheet's calculated surface level rise is adjusted by factors such as additions to the tank, evaporation of tank liquids, leakage from the tank, condensation into the tank, and existing gases within the waste matrix prior to the study period.

The December 5-6, 1995 peer review of the methodology for flammable gas evaluation determined that the surface level rise prediction was not conservative. The weakness was that evaporation was not consistently taken into account. For a select number of tanks, psychometric studies have been performed. Most tanks, especially SSTs without forced ventilation have not had psychometric studies performed. Since the review, a method was incorporated to estimate evaporation rates using tank ventilation rates and assumed inlet and outlet ventilation air conditions. The FGE spreadsheet always calculates the flammable gas concentration 3 ways (data permitting). These three methods differ only in the evaporation rate, which is expressed as a function of the ventilation rate. Flammable gas concentrations based on release events are calculated using evaporation rates based on 1) input maximum evaporation rate (line 22) or on input ventilation rate (if line 22 is 0.0 ), 2) ventilation rate determined by the heat load calculation, and 3 ) a ventilation rate determined by the vapor sample calculation.

\subsection{References}

Crippen, M. D., 1993, "Barometric Pressure Variations," WHC-EP-0651, Westinghouse Hanford Company, Richland, WA.

Sadasivan, P., Nichols, B., Spore, J., September 1995, "Passive Ventilation in Single-Shell Tanks," Los Alamos National Laboratories, Los Alamos, NM. 
WHC-SD-WM-TI-724, Rev. 1

ATTACHMENT D

\section{UNCERTAINTIES INVOLVING \\ SURFACE LEVEL GAUGES}

D-1 
This page intentionally left blank 
There are sources of uncertainty in surface level readings. One uncertainty involves changes to the waste volume. For example, evaporation of liquid would decrease waste volume. In addition, some uncertainty arises from where the surface level gauge contacts the waste.

For the surface-level-rise method to be accurate, any change in the surface level reading must be directly proportional to the change in waste volume. This is the case when the surface level is all liquid, as seen in Figure D-1. However, in many cases, a change in

Figure D-1. FIC Contacting Liquid Surface.

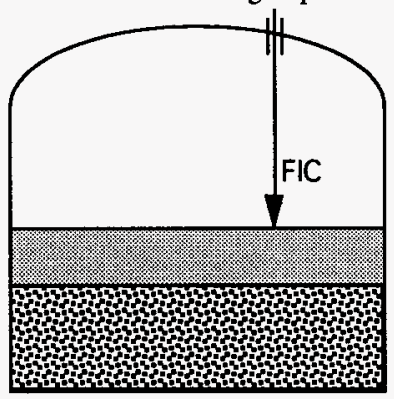

the surface level reading does not reflect a corresponding change in the volume, as illustrated by the following examples:

- The waste surface is partly covered with a floating crust of varying thickness. The crust, which varies in thickness, may move on the surface. A change in FIC reading might represent a difference in crust position, that is, no change in volume.

- The waste surface is mostly solids, and the FIC is contacting the surface of a liquid pool, near the pool's edge. If the pool evaporates, it can appear that the waste is losing more volume (that is, from a 75-foot diameter pool, instead of a small-diameter pool) than it is. As further evaporation occurs, and the FIC contacts and remains on the solids surface below where the pool was, it can appear that the waste volume is constant, even though the liquid is still evaporating. 
- Waste with a layer of supernate is pumped, and the FIC comes to rest on moist solids, as shown in Figure D.2. Although the pump continues to remove liquid waste, the loss will not be reflected in the solids surface, which remains stationary while the liquid is pumped from the interstitial space in the solids. The liquid in the solids is replaced with air from the tank head space.

Figure D-2. Pumped Tank With FIC on Solids.
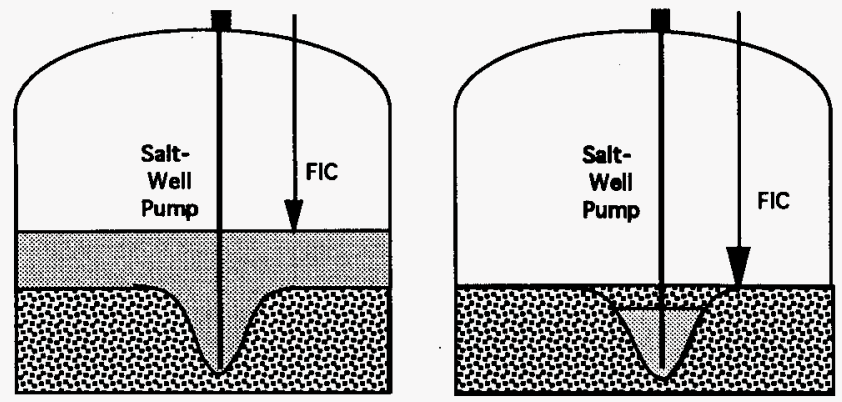

- Waste with a layer of supernate has been pumped, and the FIC has come to rest on moist solids, as shown in Figure D.3. The solids can eventually slump so that the FIC falls, making it appear that the surface level and, by inference, the waste volume are decreasing.

Figure D-3. FIC on solids falls as solids slump.
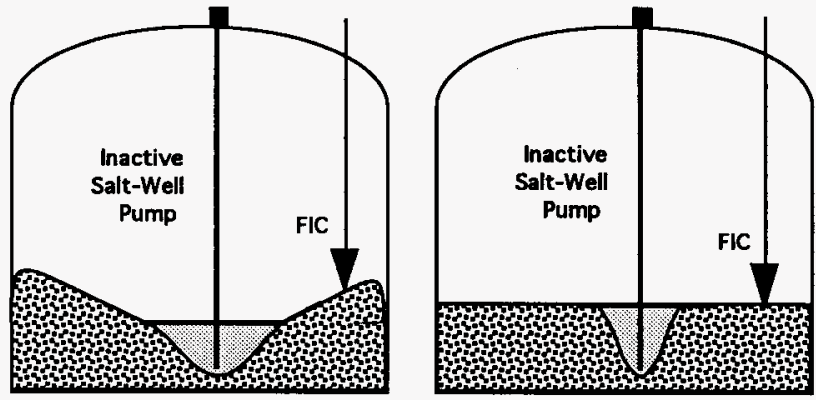
- As a variation of the foregoing case, waste with a layer of supernate has been pumped, and the FIC has come to rest in the liquid pool, as shown in Figure D.4. The solids can eventually slump so that the liquid level in the pool rises and the FIC rises, making it appear that the entire waste surface level and, by inference, the waste volume are increasing.

Figure D-4. FIC in pool rises as solids slump.
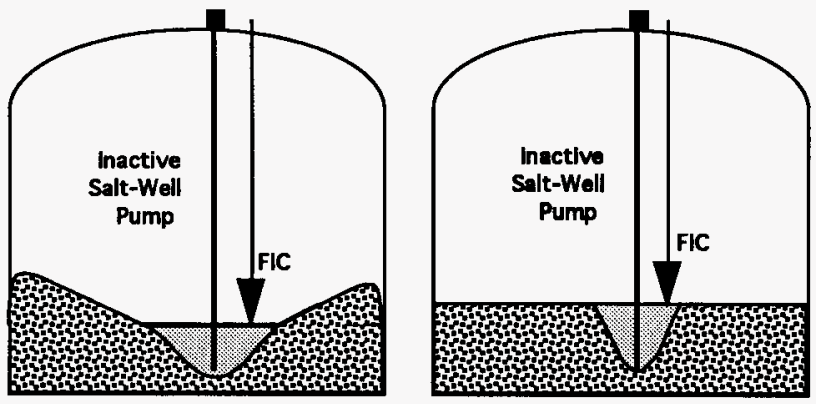

When such slumping occurs in a sludge tank, the rise in FIC level is likely to be more than for a slump of an equal volume of solids in a saltcake tank. Before sludge slumps, its volume above the water line is likely to be fairly saturated with water because of capillary action. When it slumps, it is unable to absorb any water from the pool around the pump. On the other hand, the saltcake has more pore space than sludge, and before the saltcake slumps, its pores above the water line are essentially devoid of liquid. As the salt slumps, its pores fill with water from the pool, allowing some of the pool to spread out instead of contributing to the rise.

- In a small number of tanks, repeated measurements over many years have worn a hole in the waste surface, so that current surface level readings vary, depending on where the FIC contacts the surface, as shown in Figure D.5.
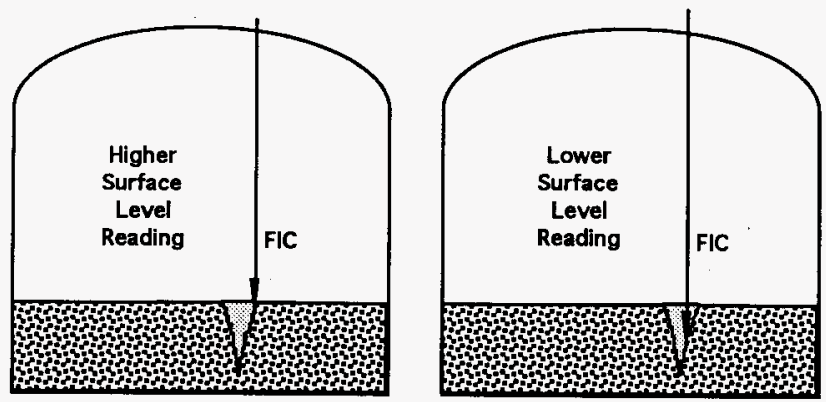
This page intentionally left blank 
WHC-SD-WM-TI-724, Rev. 1

\section{ATTACHMENT E}

\section{TECHNICAL BASIS FOR \\ CENTER OF TRAPPED GAS}

E-1 
This page intentionally left blank 
Subject: Re: Void Fraction Results from SY-103

Fran: Chuck Stewart 7/20/95 4:09 PM

To: $\quad$ Zenen Antoniak, et al.

Here are the preliminary void fraction results from SY-103 from Ruben's data sheets:

A. Ist traverse with arm away from center, sample chamber $30.5 \mathrm{ft}$ from center

B. 2nd traverse, arm toward center, sample chamber at $25.5 \mathrm{ft}$. radius

C. 3rd traverse, anm to $\mathrm{NE}$, sample chamber at $28 \mathrm{ft}$.

\begin{tabular}{|c|c|c|c|c|c|}
\hline$--(\mathrm{A})$ & & $--(B)$ & & $--(C)$ & \\
\hline $\begin{array}{l}\text { Ht (in.) } \\
\text { above } 120\end{array}$ & $\begin{array}{l}\text { Void (q) } \\
0\end{array}$ & $\begin{array}{l}\text { Ht (in.) } \\
\text { above } 120\end{array}$ & $\begin{array}{l}\text { Void (s) } \\
0\end{array}$ & Ht (in.) & Void $(z)$ \\
\hline 120 & 0 & $\begin{array}{l}116 \\
108\end{array}$ & $\begin{array}{l}0 \\
0.3\end{array}$ & & \\
\hline 96 & 0.7 & $\begin{array}{l}96 \\
84\end{array}$ & $\frac{1.3}{2.1}$ & & \\
\hline 72 & $5.5 / 5.0$ & $\begin{array}{l}72 \\
60\end{array}$ & $\begin{array}{l}2.5 \\
2.3\end{array}$ & $\begin{array}{l}68 \\
53,4\end{array}$ & $\begin{array}{l}2.4,2.0 \\
2.9\end{array}$ \\
\hline 48 & $7.6 / 7.0$ & $\begin{array}{l}43 \\
32\end{array}$ & $\begin{array}{l}3.6 \\
5.2\end{array}$ & 42.4 & 2.9 \\
\hline $\begin{array}{l}24 \\
12\end{array}$ & $\begin{array}{l}2.3 / 2.0 \\
5.6 / 5.3^{\star}\end{array}$ & 19 & $6.7 / 6.0^{\star}$ & 20.9 & $10.6,14.6$ \\
\hline
\end{tabular}

* Small gas release at this level observed as bubbles and surface motion (per telecon with Jim Alzheimer).

The notation 5.6/5.3 indicates a double pressurization of the same sample, while 2.4,2.0 indicates two tests at the same location with cover opened and closed between.

Chuck 
Plots of data presented in Stewart's mail message are shown below. Integrals were determined by algebraically calculating cumulative sums of inches $\mathbf{x}$ void fraction. Void fractions at zero inches are assumed based on extrapolation of VF curve. Mid-point of integral is about 36 in. for Run 1 and about 24 inches for Run 2. Average $=30$ in. Solids depth $=130-132$ in. Fraction of wet-solids depth above tank bottom $=30$ in./130 in. $=$ 0.231 .
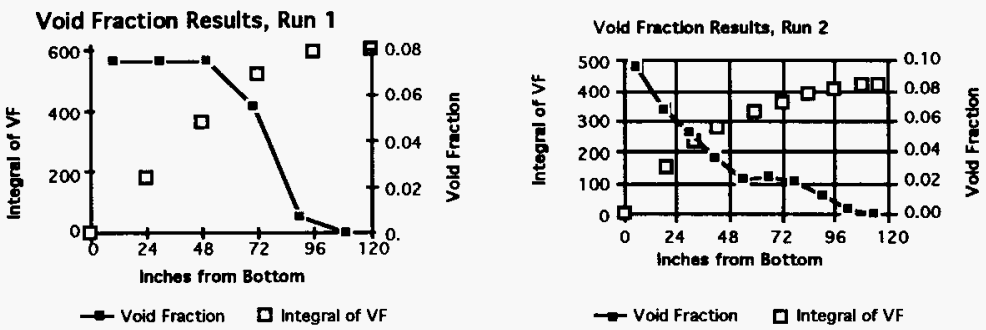
WHC-SD-WM-TI-724, Rev. 1

\section{ATTACHMENT F}

\section{MONTE CARLO ANALYSIS}


This page intentionally left blank 


\section{F-1.0 DEFINITION OF DISTRIBUTIONS}

Members of the evaluation team have defined distributions for the parameters listed in Table F-1. The distributions for measures are based in part on a knowledge of statistical variation of parameters and in part on engineering judgment based on the character and behavior of tank waste.

The distributions for "\% $\mathrm{H}_{2}$ in trapped gas" (line 37) and "\% of trapped gas releasable" (line 38) are predominantly based on engineering judgment, which draws on experimental reports, tank models and calculations regarding a few DSTs. The distribution for barometric slope (line 61) is based on surface level and barometric pressure data but is influenced by Whitney's judgment about how to identify statistically significant correlations among the data.

Table F-1. Terms Included in Monte Carlo Simulation. (2 sheets)

\begin{tabular}{|c|c|c|c|c|c|}
\hline Line & Description & Mean & SD* & Limits** & $\begin{array}{l}\text { Value Used in } \\
\text { Spreadsheet }\end{array}$ \\
\hline 8 & $\begin{array}{l}\text { Current solid surface } \\
\text { level height }\end{array}$ & $\begin{array}{l}\text { Current } \\
\text { reading }\end{array}$ & $\begin{array}{l}2.0 \\
\text { in. }\end{array}$ & $\pm 4 \mathrm{SD}$ & Mean \\
\hline 11 & $\begin{array}{l}\text { Current liquid level } \\
\text { height }\end{array}$ & $\begin{array}{l}\text { Current } \\
\text { reading, } \\
\max = \\
1.40\end{array}$ & 2 in. & $\pm 4 \mathrm{SD}$ & Mean \\
\hline 17 & Supernate density & $\begin{array}{l}\text { Value } \\
\text { from } \\
\text { literature, } \\
\text { default = } \\
1.40\end{array}$ & $\begin{array}{l}0.05 \\
\mathrm{~g} / \mathrm{mL}\end{array}$ & $\begin{array}{l}\text { Min = mean - } \\
4 \mathrm{SD} \text {. Max = } \\
\text { mean + } 4 \mathrm{SD} \text {, or } \\
\text { min of solids } \\
\text { density, which- } \\
\text { ever is less }\end{array}$ & Mean \\
\hline 18 & Solids density & $\begin{array}{l}\text { Value } \\
\text { from } \\
\text { literature, } \\
\text { default = } \\
1.80\end{array}$ & $\begin{array}{l}0.05 \\
\mathrm{~g} / \mathrm{mL}\end{array}$ & $\begin{array}{l}\text { Min = mean - } \\
4 \text { SD or } \\
\text { supernate mean, } \\
\text { whichever is } \\
\text { greater. Max = } \\
\text { mean + } 4 \mathrm{SD}\end{array}$ & Mean \\
\hline 19 & $\begin{array}{l}\text { Porosity (liquid fraction) } \\
\text { in solids, by assay } \\
\text { [Entry for saltcake] }\end{array}$ & $\begin{array}{l}0.501 \text { or } \\
\text { experi- } \\
\text { mental } \\
\text { value }\end{array}$ & 0.075 & $\pm 2 \mathrm{SD}$ & Mean \\
\hline 19 & $\begin{array}{l}\text { Porosity (liquid fraction) } \\
\text { in solids, by assay } \\
\text { [Entry for sludge] }\end{array}$ & $\begin{array}{l}0.16 \text { or } \\
\text { experi- } \\
\text { mental } \\
\text { value }\end{array}$ & 0.035 & $\pm 2 \mathrm{SD}$ & Mean \\
\hline 21 & $\begin{array}{l}\text { Average gas location: } \\
\text { fraction of wet solids } \\
\text { from bottom }\end{array}$ & 0.225 & 0.01 & $\pm 4 \mathrm{SD}$ & Mean \\
\hline
\end{tabular}

SD is not a true standard deviation, but rather it represents the evaluation team's consensus of the variability of the parameter.

** Mean \pm 3 SD covers $99.7 \%$ of possible values; mean \pm 4 SD, $99.99 \%$ of values. 
Table F-1. Terms Included in Monte Carlo Simulation. (2 sheets)

\begin{tabular}{|c|c|c|c|c|c|}
\hline Line & Description & Mean & SD* & Limits** & $\begin{array}{l}\text { Value Used in } \\
\text { Spreadsheet }\end{array}$ \\
\hline 25 & $\begin{array}{l}\text { Average trapped gas } \\
\text { temperature }\end{array}$ & $\begin{array}{l}\text { Value } \\
\text { from PC- } \\
\text { SACS }\end{array}$ & $2 \%$ & $\begin{array}{l} \pm(0.1 \text { x mean }) \\
\text { or } \pm 4 \text { SD (varies } \\
\text { by evaluator) }\end{array}$ & Mean \\
\hline 37 & $\begin{array}{l}\% \mathrm{H} 2 \text { in trapped gas, } \mathrm{ft} 3 \\
\mathrm{H} 2 / \mathrm{ft} 3 \text { gas } \times 100 \%\end{array}$ & $50 \%$ & $15 \%$ & $2 \% ; 97 \%$ & $\begin{array}{l}97 \% \text { theoretical } \\
\text { max (for } \\
\text { conservatism) } \\
\text { vs. } 75-90 \% \\
\text { observed }\end{array}$ \\
\hline 38 & $\begin{array}{l}\text { \% of trapped gas } \\
\text { releasable }\end{array}$ & $\begin{array}{l}15 \% \\
\text { Log- } \\
\text { normal }\end{array}$ & $14 \%$ & $\begin{array}{l}\text { Low }=0 \% \\
\text { High }=75 \%\end{array}$ & $\begin{array}{l}25 \% \text { (higher in } \\
\text { AW- } 101 \text { ); } \\
\text { assumed to give } \\
\text { conservative } \\
\text { results for } \\
\text { normal } \\
\text { operations. May } \\
\text { not be } \\
\text { conservative for } \\
\text { earthquake. }\end{array}$ \\
\hline 61 & Barometric slope & Qfit mean & $\begin{array}{l}\text { Qfit } \\
\text { SD }\end{array}$ & $\begin{array}{l}\text { Low = value } \\
\text { which gives } \\
\text { void fraction } \\
\text { of } 0 \text {. High }= \\
\text { value which } \\
\text { gives void } \\
\text { fraction of } 0.300 \\
\text { (wet solids) }\end{array}$ & $\begin{array}{l}75 \text { percentile } \\
\text { slope; assumed } \\
\text { to give } \\
\text { conservative } \\
\text { results. Spread- } \\
\text { sheet limits slope } \\
\text { to value which } \\
\text { gives void } \\
\text { fraction }=0.300 \text {. }\end{array}$ \\
\hline 201 & Tank total volume, $\mathrm{ft}^{3}$ & $\begin{array}{l}\text { From } \\
\text { look-up } \\
\text { table in } \\
\text { spread- } \\
\text { sheet }\end{array}$ & $\begin{array}{l}500 \\
\mathrm{ft}^{3}\end{array}$ & $\pm 4 \mathrm{SD}$ & Mean \\
\hline
\end{tabular}

For the calculation of \% LFL based on surface level rise, no distributions were defined for terms adjusting the surface level (for example, evaporation or gas trapped at beginning of period). Lack of time prevented defining these distributions. The sum of these distributions is probably quite wide, so the variation in the \% LFL calculated by surface level rise may be greater than the variation in \% LFL calculated from barometric slope.

Sensitivity analysis shows that about $90 \%$ of the variation in the calculated $\%$ LFL is from the variation in the following terms: barometric slope, $\% \mathrm{H}_{2}$ in trapped gas, and \% of gas released. This is to be expected. There is a wide range of possible values for each of these parameters, and for a given tank the value of these parameters used in the spreadsheet may be significantly different from the actual value. This is especially true for the $\% \mathrm{H}_{2}$ in the gas and the percent of trapped gas released. For each of these parameters, the Monte Carlo defined distribution is generalized for all tanks (that is, the same trio of distributions is used for all tanks) and is therefore very wide. It may be possible to narrow the distribution on a tank-by-tank basis and thereby narrow the range of the calculated \% LFL. 


\section{F-2.0 SPREADSHEET VALUES}

For the three parameters discussed in the previous paragraph, to provide conservatism in the calculated \% LFL, the evaluators used spreadsheet values at the upper end of the distribution range, as shown in the table. It is not unreasonable to use values this high, as discussed below.

- Barometric slope. The spreadsheet has a logic step which limits the slope to the value corresponding to a void fraction of 0.30 in wet solids. Informal discussions among some reviewers of this methodology indicate that although this is an arbitrary ceiling, it seems appropriate in light of tank behavior and laboratory experiments.

- $\% \mathrm{H}_{2}$ in trapped gas. The spreadsheet uses the value of $97 \%$. Estimates of releases in DSTs since mid-1994 indicate that gas released could have contained $70-90 \% \mathrm{H}_{2}$, which is not far below 97\%. If the distribution curve were modifed for each individual tank based on in situ sampling (if that were possible), the mean of distribution curve might be well above $50 \%$ for many tanks.

- \% of gas released. The spreadsheet uses $25 \%$. Again, although this is an arbitrary ceiling, most reviewers of this methodology agree that this value appears to be reasonable for normal conditions in SSTs, although in an earthquake the release might be greater than $50 \%$. Experimental work is needed as a technical basis for estimating the release in an earthquake.

NOTE: In 101-SY, the prompt release was calculated to have reached about $39 \%$ of the trapped slurry gas. For DSTs, the evaluation team used a $25 \%$ release except for tank AW-101, for which the Raleigh-Taylor/Neutral Buoyancy method predicted a maximum release of $47 \%$. This was the only tank for which a release greater than $25 \%$ was assumed.

For parameters besides the three discussed above, the spreadsheet uses the mean of each Monte Carlo distribution. This tends not to give conservative results, however, the variance in these parameters accounts for only about $10-15 \%$ of the variation in the calculated \% LFL, therefore the use of mean values instead of conservative values is not expected to have a major effect on the result.

\section{F-3.0 EXAMPLE PRINTOUT}

The following pages contain an example Monte Carlo report for tank S-106, including the distribution of the \% LFL based on barometric evaluation; \% LFL based on surface level rise; compressed volume of trapped gas, and \% void. Because the report is only for illustration, only 2,500 trials were run, instead of the usual 5,000. 


\section{Crystal Ball Report}

\section{SENSTIVITY CHAFT}

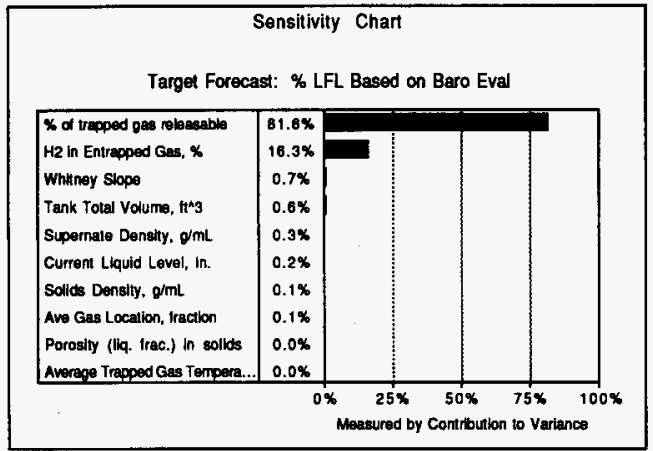

\section{FORECASTS}

Forecast: \% LFL Based on Baro Eval

\begin{tabular}{|c|c|}
\hline $\begin{array}{l}\text { Summary: } \\
\text { Display Range is fro } \\
\text { Entire Range is from } \\
\text { After 2,594 Trials, th }\end{array}$ & \\
\hline Statistics: & Yalue \\
\hline Trials & 2594 \\
\hline Mean & $66 \%$ \\
\hline Median (approx.) & $48 \%$ \\
\hline Mode (approx.) & $24 \%$ \\
\hline Standard Deviation & $58 \%$ \\
\hline Variance & $34 \%$ \\
\hline Skewness & 2.12 \\
\hline Kurtosis & 9.30 \\
\hline Cooff. of Variability & 0.87 \\
\hline Range Minimum & $2 \%$ \\
\hline Range Maximum & $477 \%$ \\
\hline Range Width & $474 \%$ \\
\hline Mean Sid. Error & $1.14 \%$ \\
\hline
\end{tabular}

Cell: 0776

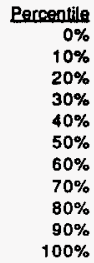

$\%$ LFL_(anorox) $2 \%$

$16 \%$

$24 \%$

$31 \%$

$40 \%$

$48 \%$

$60 \%$

$75 \%$

$\mathbf{9 7 \%}$

$140 \%$

$477 \%$

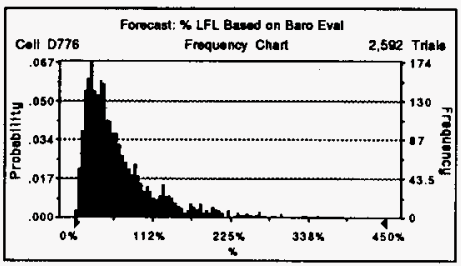

End of Forecast 
Forecast: Compressed Vol of Trapped Gas, ft3

Cell: D777 Cell: $\quad 0777$

Summary:

Display Range is from 12000 to $20000 \mathrm{ft}$

Entire Range is from 3518 to $19464 \mathrm{ft3}$

Aller 2,594 Trials, the Std. Error of the Mean is 39

\begin{tabular}{lr} 
Statistics: & Yalue \\
\hline Trials & 2594 \\
Mean & 17744 \\
Median (approx.) & 18612 \\
Mode (approx.) & 18746 \\
Standard Deviation & 2003 \\
Variance & 4010023 \\
Skewness & -2.47 \\
Kurlosis & 10.17 \\
Coeff. of Variability & 0.11 \\
Range Minimum & 3518 \\
Range Maximum & 19464 \\
Range Width & 15946 \\
Mean Std. Error & 39.32
\end{tabular}

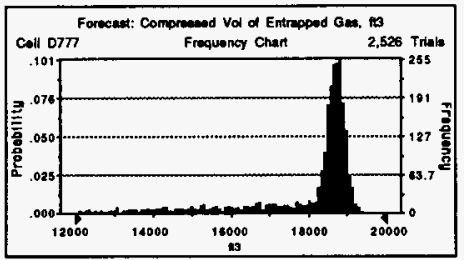

\begin{tabular}{rc} 
Percentile & 113 fapprox \\
\hline $0 \%$ & 3518 \\
$10 \%$ & 14840 \\
$20 \%$ & 16859 \\
$30 \%$ & 18251 \\
$40 \%$ & 18501 \\
$50 \%$ & 18612 \\
$60 \%$ & 18697 \\
$70 \%$ & 18777 \\
$80 \%$ & 18858 \\
$90 \%$ & 18966 \\
$100 \%$ & 19464
\end{tabular}

Mean Std. Error

Forecest: $\%$ Vold

Cell: 0778

Summar:

Display Range is from $20 \%$ to $30 \% \%$

Entire Range is from $6 \%$ to $30 \% \%$

After 2,594 Trials, the Sid. Enror of the Mean is $0 \%$

\begin{tabular}{lr} 
Statistics: & Value \\
\hline Trials & $25 \% 4$ \\
Mean & $28 \%$ \\
Median (approx.) & $30 \%$ \\
Mode (approx.) & $30 \%$ \\
Standard Deviation & $3 \%$ \\
Variance & $0 \%$ \\
Skewness & -2.50 \\
Kurtosis & 10.24 \\
Coeft. of Variability & 0.11 \\
Range Minimum & $6 \%$ \\
Range Maximum & $30 \%$ \\
Range Width & $24 \%$ \\
Mean Std. Error & $0.06 \%$
\end{tabular}

\begin{tabular}{rc} 
Percentile & $\%$ Void aporox. \\
\hline $0 \%$ & $6 \%$ \\
$10 \%$ & $24 \%$ \\
$20 \%$ & $27 \%$ \\
$30 \%$ & $29 \%$ \\
$40 \%$ & $30 \%$ \\
$50 \%$ & $30 \%$ \\
$60 \%$ & $30 \%$ \\
$70 \%$ & $30 \%$ \\
$80 \%$ & $30 \%$ \\
$90 \%$ & $30 \%$ \\
$100 \%$ & $30 \%$
\end{tabular}

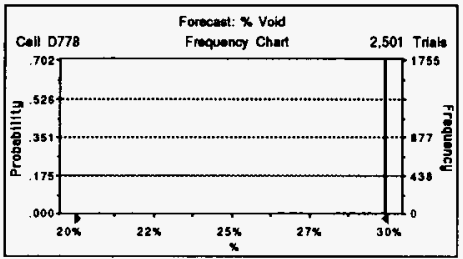




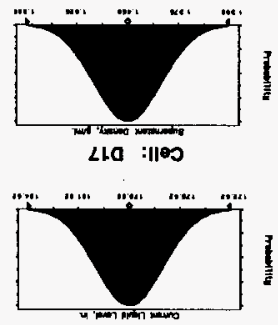

HLO : IOP

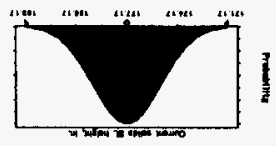

80 :ाष्O

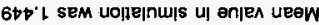

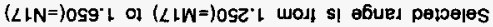

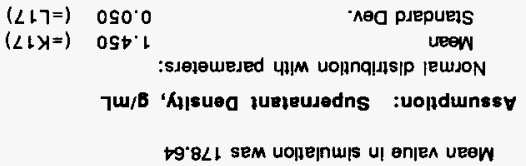

-u '74bןe4 75 splos juesno :uopdunssy

SNOudwnssy

Iseperoy to pug

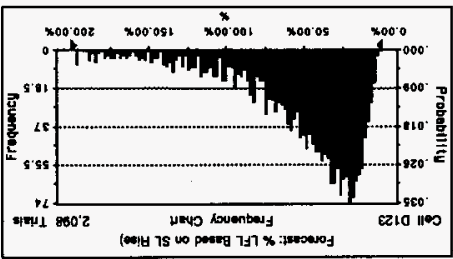

\begin{tabular}{|c|c|}
\hline 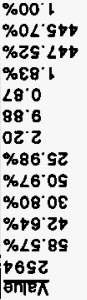 & 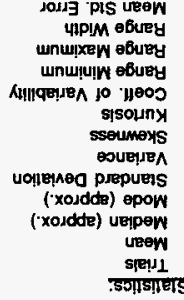 \\
\hline
\end{tabular}

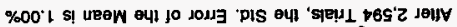

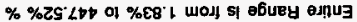
$\% \% 00^{\circ} 00 z$ ol $\% 00^{\circ} 0$ wos! s! oburey Aejds!a xiewdin's 
Aseumption: Solids Density, $\mathbf{g} / \mathrm{mL}$

Normal distrlbution with parameters:

$$
\begin{array}{lll}
\text { Mean } & 1.50 & (=K 18) \\
\text { Standard Dev. } & 0.05 & (=L 18)
\end{array}
$$

Selected range is from 1.45 to $1.70(=\mathrm{N} 18)$

Mean value in simulation was 1.52

Assumption: Porosity (Ilq. frac.) In soljds

Normal distributlon with parameters:

$$
\begin{array}{lll}
\text { Mean } & 0.407 & \text { (=K19) } \\
\text { Standard Dov. } & 0.061 & \text { (L19) }
\end{array}
$$

Selected range is from $0.257(=\mathrm{M} 19)$ to $0.557(=\mathrm{N} 19)$ Mean value in simulation was 0.406

Assumption: Ave Gas Location, fraction

Normal distribution with parameters:

$$
\begin{array}{lll}
\text { Mean } & 0.225 & (=K 21) \\
\text { Standard Dev. } & 0.010 & (=L 21)
\end{array}
$$

Selected range is from $0.185(=\mathrm{M} 21)$ to $0.265(=\mathrm{N} 21)$ Mean value in simulation was 0.225

Assumption: Average Trapped Gas Temperature, ${ }^{\circ} \mathrm{F}$ Normal distrlbution with parameters:

$$
\begin{array}{lrl}
\text { Mean } & 77 & \text { (=K25) } \\
\text { Standard Dov. } & 2 & \text { (=L25) }
\end{array}
$$

Selected range is from $69(=\mathrm{M} 25)$ to $85(=\mathrm{N} 25)$

Mean value in simulation was 77

Assumption: $\mathrm{H} 2$ in Entrapped Gas, \%

Normal dlstribution with parameters:

$$
\begin{array}{lll}
\text { Mean } & 50 \% & (=\mathrm{K} 37) \\
\text { Standard Dev. } & 15 \% & (=\mathrm{L} 37)
\end{array}
$$

Selected range is from $2 \%(=\mathrm{M} 37)$ to $97 \%(=\mathrm{N} 37)$

Mean value in simulation was $49 \%$

\section{Assumption: $\%$ of trapped gas releasable}

Lognormal distribution with parameters:

$$
\begin{array}{lll}
\text { Mean } & 15.0 \% & \text { (=K38) } \\
\text { Standard Dev. } & 14.0 \% & \text { (=L38) }
\end{array}
$$

Selected range is from $0.0 \%$ to $75.0 \%$

Mean value in simulation was $14.3 \%$

\section{Assumption: Whitney Slope}

Normal distribution with parameters:

$$
\begin{array}{lrl}
\text { Mean } & -1.25 & (=\mathrm{K} 61) \\
\text { Standard Dev. } & 0.27 & (=\mathrm{L} 61)
\end{array}
$$

Selected range is from $-5.00(=\mathrm{M} 61)$ to $5.00(=\mathrm{N} 61)$

Mean value in simulation was -1.25

\section{Assumption: Tank Total Volume, $\mathrm{ft}^{\wedge} 3$}

Normal distribution with parameters:

$$
\begin{array}{lrl}
\text { Mean } & 140,600 & (=K 29) \\
\text { Standard Dev. } & 500 & (=L 29)
\end{array}
$$

Selected range Is from $139,194(=\mathrm{M} 29)$ to $142,006(=\mathrm{N} 29)$ Mean value in simulation was 140,603

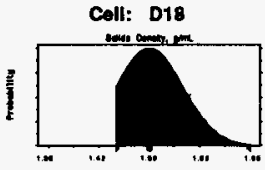

Cell: Dto

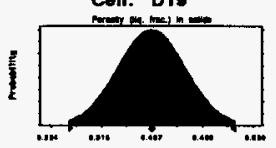

Cell: D21

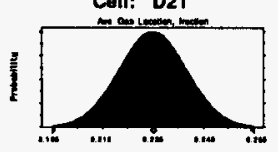

Coll: 025

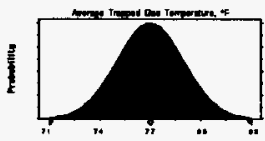

Cell: D37

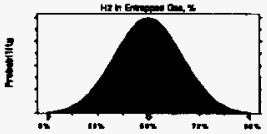

Cell: D38

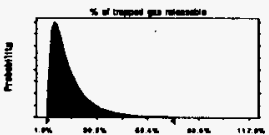

Cell: D61

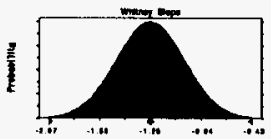

Cell: J29

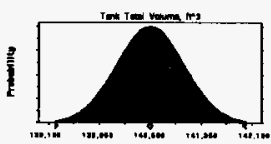


This page intentionally left blank. 
WHC-SD-WM-TI-724, Rev. 1

\section{ATTACHMENT G}

\section{DISTRIBUTION OF SLOPES}


WHC-SD-WM-TI-724, Rev. 1

Attachment $\mathrm{G}$

This page intentionally left blank 
The ranges of slopes determined by Whitney (1995) for an individual tank for a period of time (e.g., January 1991 through summer 1995) can be summed mathematically and depicted graphically by an approximate distribution, as shown by the solid curve on Figure G.1. The distribution can be divided into quantiles, and an approximate mean and an approximate standard deviation can be determined as well. The slope of -1.44 in. of level per in. $\mathrm{Hg}$ at the 0.25 quantile is the 75 -percentile slope, that is, $75 \%$ of the slope values are less negative than -1.44 in. of level per in. $\mathrm{Hg}$.

The approximating distribution cannot be described simply in the software program Crystal Ball ${ }^{1}$, which is used to perform Monte Carlo analyses. Therefore, Whitney has defined "Qfit," a Gaussian distribution which has the same 25-percentile and 75-percentile values as the approximating distribution. The Qfit mean and a Qfit SD can be entered into Crystal Ball ${ }^{\mathrm{M}}$ to represent the approximating distribution. See Whitney's explanation in his mail message reproduced on page $\mathrm{G}-5$.

\section{REFERENCE}

Whitney, P. D., 1995, Screening the Hanford Tanks for Trapped Gas, PNL-10821, Pacific Northwest Laboratory, Richland, Washington.

1 Crystal Ball is a registered trademark of Decisioneering. Inc. of Aurora, Co. 


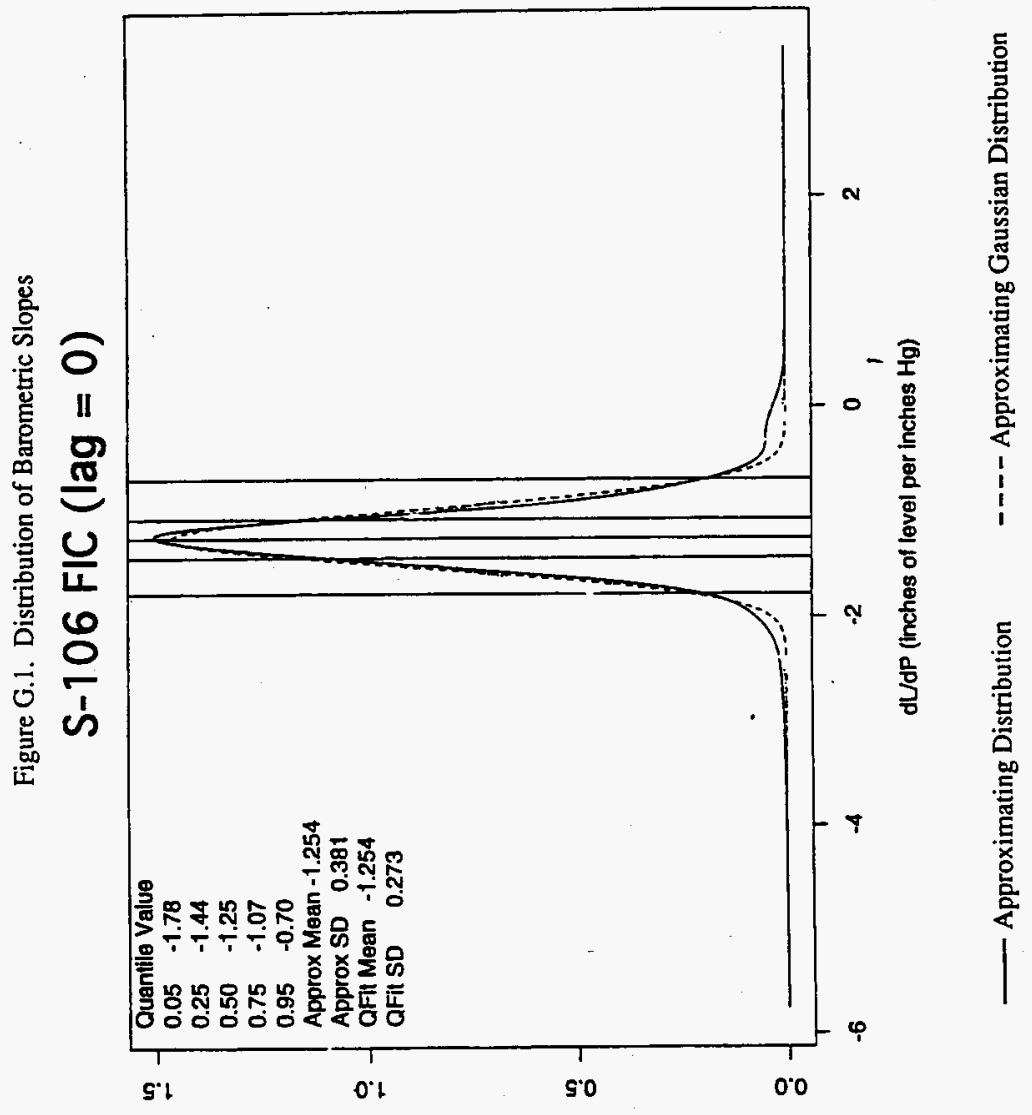




cc:Mail for: James D (Dave) Hopkins
Subject: OfI
From: whitney@blake.pnl.gov at -SMTPlink $11 / 21 / 95 \quad 11: 55$ AM
To: James D (Dave) Hopkins at $\sim$ WHC55
cc: Kent M Hodgson at -WHC215

Dave,

The distribution used to summarize the slope estimate is described in section 5.2 of the report PNL-10821. Since Crystal Ball cannot take that generic a distribution as input, an approximating Gaussian distribution was made by matching the first and third quantiles of the summary distribution and a Gaussian distribution. The resulting mean and standard deviation of this approxmating Gaussian distribution are reported on the "histogram" plots as QFit Mean and QFit SD, respectively. Also, on these plots the solid line shows the approximating distribution and the dashed line shows the approximating Gaussian distribution.

-Paul 
This page intentionally left blank 
WHC-SD-WM-TI-724, Rev. 1

\section{ATTACHMENT H}

\section{VOID FRACTION RESULTS \\ FOR TANK 241-SY-103}


This page intentionally left blank 


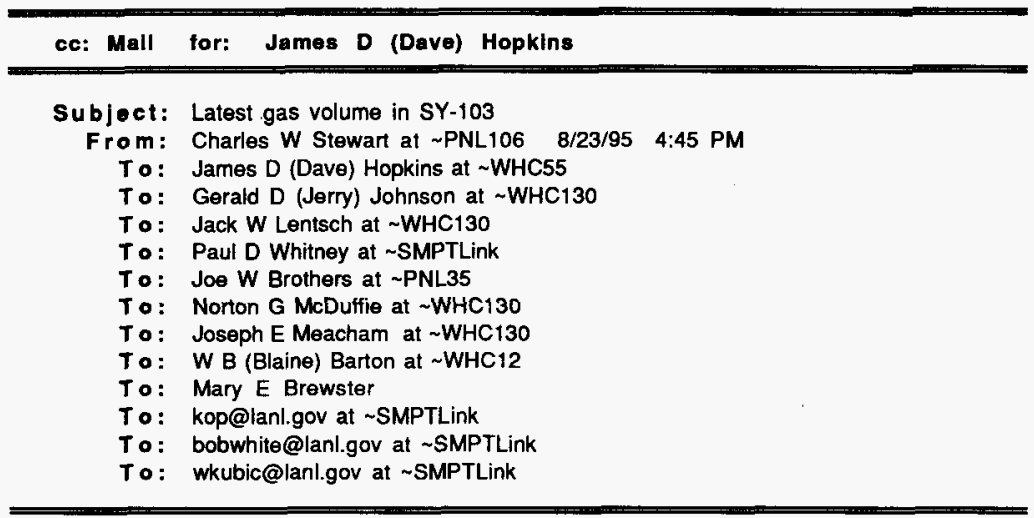

Having received the 'validate' and re-calculated void fractions from Jim Alzheimer last night, I have recalculated the gas volumes. Here is what I get:

Both risers have:

Waste surface level $=272$ inches

Max sludge depth $=130$ inches

$22 \mathrm{~A}$ riser - may represent 'pre-GRE' state

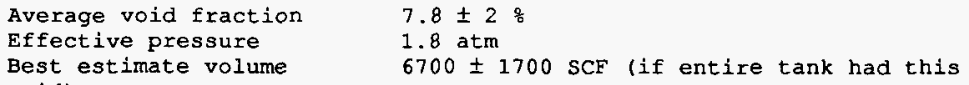


WHC-SD-WM-TI-724, Rev. 1

Attachment $\mathrm{H}$

This page intentionally left blank.

H-4 
WHC-SD-WM-TI-724, Rev. 1

\section{ATTACHMENT I}

\section{CONDITIONS NOT EVALUATED}


This page intentionally left blank 
Section 2.0 of this document defines four flammable gas conditions in which gas from the waste might exceed safe limits and be a factor in the release of waste to the environment: the steady-state concentration of flammable gas in the tank headspace, the concentration after an EGR, the ignition of a gas plume as it escapes from the waste, and overpressurization of a tank's exhaust filter caused by the release of pressurized gas from the waste. Sections 4.0 through 8.0 present the method for evaluating steady-state and post-EGR conditions, except for potential future increases in entrapment. Future entrapment is discussed briefly in Section I-1.0 below.

The main body does not discuss plume burn or overpressurization. A brief discussion of the plume burn is provided in Section I-2.0 for background, and a discussion of overpressurization is provided in Section I-3.0 for possible use in future evaluations.

\section{I-1.0 POTENTIAL FUTURE ENTRAPMENT}

Attachment B, paragraph 5.5, requires that even if a tank is found not to meet the flammable gas criteria, the tank's trends must be evaluated to determine whether it has the potential to increase the size of gas release in the foreseeable future. For example, if analysis of a tank's surface level shows an EGR in the tank currently could attain $24 \%$ of the LFL (100 low to meet the criteria), but the tank has a steadily increasing level rise and might exceed the $25 \%$ level in the near future, then the tank should be considered to exceed the criteria.

\section{I-2.0 EVALUATION OF PLUME BURN POTENTIAL}

Evaluating whether a plume burn can cause failure in an SST requires information not yet available. Heard (1995) has performed a modeling study to determine the pressure required to cause exhaust high-efficiency particulate air (HEPA) filter failure in DST SY101. A plume of about $190 \mathrm{ft}^{3}$, containing $48 \% \mathrm{H}_{2}$ and $48 \% \mathrm{~N}_{2} \mathrm{O}$ could generate the 10 in. w.g. pressure differential required to cause failure of the exhaust HEPA filter in this DST. A plume of about $50 \mathrm{ft}^{3}$ of the same mixture could generate the 10 in. water gauge (w.g.) needed to cause failure of the tank's inlet HEPA filter (Heard 1995). Because the HEPA filter on an SST is located at the top of a riser, as is the 101-SY inlet filter, it is assumed that a $50-\mathrm{ft}^{3}$ plume also could cause failure of an SST HEPA filter in an SST filled with waste. The explosive force of this plume could be generated by a plume of about 25 $\mathrm{ft}^{3}$ of $97 \% \mathrm{H}_{2}$, assuming this plume mixed with air and underwent $100 \%$ combustion.

The criteria for plume burns requires that a tank not be able to have a burn of a plume which has $25 \%$ of the volume which could cause a serious release to the environment. Whether a plume burn of that size is credible in an SST must be determined by safety analysis. 


\section{I-3.0 EVALUATION OF OVERPRESSURIZATION}

There is a concern that when pressurized gas is released from tank waste, it can overpressurize the tank's HEPA filter. New HEPA filters can withstand an overpressure of about $6.9 \mathrm{kPa}$ ( $1 \mathrm{psi}$, or 27.7 in. w.g.) However, when a filter is placed into service, its pores begin to accumulate fine specs of dust, thereby decreasing the rate at which the filter relieves the overpressure. Moreover, the filter material and strength degrade after prolonged exposure to heat. The longer a filter is used, the lower the overpressure it can withstand. HEPA filters are rated to withstand only $2.49 \mathrm{kPa}$ (10.0 in. w.g., or 0.361 psi) (DOD 1988). Including a factor-of-four safety margin in accordance with the flammable gas criteria document (Hopkins 1994), the criterion for overpressurization is a pressure differential of $0.623 \mathrm{kPa}$ (2.50 in. w.g., or $0.0903 \mathrm{psi}$ ).

\section{I-3.1 OVERPRESSURIZATION QUICK SCREEN}

A quick screen to determine whether a release can overpressurize a tank can be made by determining how much trapped gas would have to be instantly released to overpressurize the filter and comparing that to how much gas can be released. For example, if a tank would have to instantly release $100 \mathrm{~m}^{3}$ of trapped gas, but it contains only $50 \mathrm{~m}^{3}$ and could only release $25 \%$ of that $\left(12.5 \mathrm{~m}^{3}\right)$, the tank could not possibly exceed the overpressurization criterion. In this example, the ratio of the required instantaneous release to the maximum possible release is $200: 12.5$, that is, $8: 1$. Here, a $100 \mathrm{~m}^{3}$ release corresponds to a release fraction of 2.0 , so the ratio of the required instantaneous release fraction to the maximum possible release fraction, 0.25 , is also $8: 1$.

Therefore, a quick screen can be performed by calculating the required release fraction, $k$, and comparing that to 0.25 . If the required instantaneous release is greater than 0.25 , the tank can not possibly overpressurize the HEPA filter, that is, could not possibly exert an overpressure of $0.623 \mathrm{kPa}$ on the HEPA filter. A formula for calculating whether this can occur in a tank is derived in Sections I-3.1.1 and I-3.1.2.

\section{I-3.1.1 Assumptions}

The following conservative assumptions are made.

- The release is adiabatic; that is, with the system defined as the headspace gas plus the gas released into the headspace, the system neither gains nor loses heat during the release.

- The release of trapped gas from the waste is instantaneous.

- The final volume, $V_{f}$, of the headspace (after the gas is released from the waste) is the volume of the headspace before the release, $\mathrm{V}_{\mathrm{h}}$, plus the in situ volume of the gas release, $\mathrm{kV}_{\mathrm{t}}$, where $\mathrm{k}$ is the release fraction and $\mathrm{V}_{\mathrm{t}}$ is the total volume of trapped gas. That is, $V_{f}=V_{h}+k V_{t}$. See Figure I-1. 
Figure I-1. Gas Release Increases Headspace.

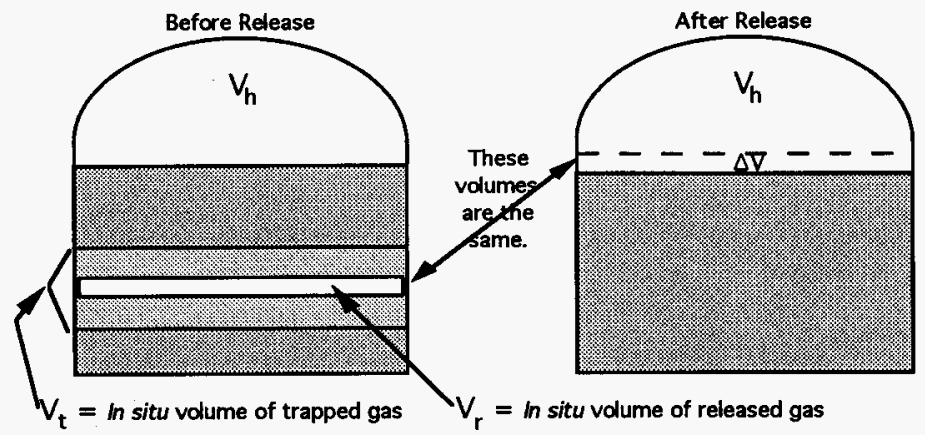

\section{I-3.1.2 Calculations}

The final pressure is determined by calculating the headspace temperature after the release, then using that temperature to calculate the final pressure. The calculation has three parts. Note that for parameters in this section, subscripted letters have the following meanings:

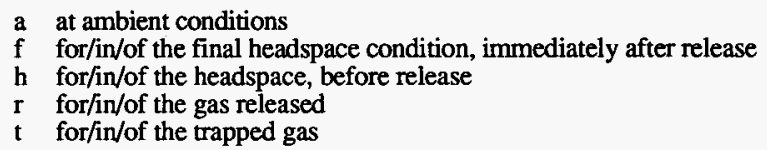

Part 1: Calculate the amount of heat given off when the released gas cools to $T_{h}$. As shown in Figure I-2, the temperature of the trapped gas, $T_{b}$, is greater than the initial headspace gas temperature, $T_{h}$. Therefore, the final temperature of the headspace gas will be a bit higher than $T_{h}$.

Figure I-2. Calculate the Final

Temperature of Headspace Gas in Two Steps

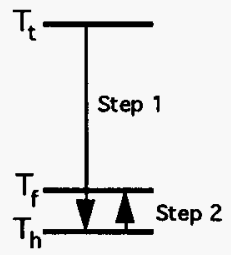


The heat released, $Q$, when the plume cools to $T_{h}$ in Step 1 is:

$$
Q=n_{r} \times C_{p}^{t} \times \Delta T=k n_{t} \times C_{p}^{t} \times\left(T_{t}-T_{h}\right)
$$

Note: $\quad C_{p}^{t}=$ specific heat (at constant pressure) of the trapped gas

$\mathrm{n}_{\mathrm{r}}=$ moles of gas released

$\mathrm{n}_{\mathrm{t}}=$ moles of trapped gas

$\mathbf{k}=$ fraction of gas released

$\mathrm{C}_{\mathrm{p}}$ values are shown in Table $\mathrm{I}-1$.

Table I-1. Specific Heats

\begin{tabular}{|l|c|}
\hline Gas & $\begin{array}{c}\mathrm{C}_{\mathrm{p}} \\
\text { joules/mol- }\end{array}{ }^{\circ} \mathrm{C}$ \\
\hline $\mathrm{Air}$ & 29.16 \\
$\mathrm{H}_{2}$ & 28.82 \\
$\mathrm{H}_{2} \mathrm{O}$ & 33.9 \\
$\mathrm{~N}_{2}$ & 29.12 \\
$\mathrm{~N}_{2} \mathrm{O}$ & 38.45 \\
\hline
\end{tabular}

Part 2: Return the heat back to the mixture of plume gas and headspace air to raise the temperature of the combined gas, as shown in Step 2 in Figure I-2. Using the value of $Q$ from Part 1, calculate the resulting temperature as follows:

$$
Q=\left(k n_{t} C_{p}^{t}+n_{h} C_{p}^{h}\right) \times\left(T_{f}-T_{h}\right)
$$

where $\quad C_{\mathbf{p}}^{\text {h }}=$ specific heat (at constant pressure) of the headspace gas before the release

Substituting for $\mathrm{Q}$ from Equation I-1.

$$
\begin{aligned}
Q & =k n_{t} C_{p}^{t}\left(T_{t}-T_{h}\right)=\left(k n_{t} C_{p}^{t}+n_{h} C_{p}^{h}\right) \times\left(T_{f}-T_{h}\right) \\
\left(T_{f}-T_{h}\right) & =k n_{t} C_{p}^{t}\left(T_{t}-T_{h}\right) /\left(k n_{t} C_{p}^{t}+n_{h} C_{p}^{h}\right) \\
T_{f} & =\frac{T_{h}+\frac{k n_{l} C_{p}^{t}\left(T_{t}-T_{h}\right)}{k n_{t} C_{p}^{t}+n_{h} C_{p}^{h}}}{T_{f}}=T_{h}+\frac{k n_{t} C_{p}^{t} T_{t}-k n_{t} C_{p}^{t} T_{h}}{k n_{t} C_{p}^{t}+n_{h} C_{p}^{h}} \\
T_{f} & =\frac{T_{h}\left(k n_{t} C_{p}^{t}+n_{h} C_{p}^{h}\right)}{k n_{1} C_{p}^{t}+n_{h} C_{p}^{h}}+\frac{k n_{t} C_{p}^{t} T_{t}-k n_{t} C_{p}^{t} T_{h}}{k n_{t} C_{p}^{t}+n_{h} C_{p}^{h}} \\
T_{f} & =\frac{T_{h}\left(k n_{t} C_{p}^{t}+n_{h} C_{p}^{h}\right)+k n_{l} C_{p}^{t} T_{t}-k n_{t} C_{p}^{t} T_{h}}{k n_{t} C_{p}^{t}+n_{h} C_{p}^{h}}
\end{aligned}
$$




$$
\begin{aligned}
& T_{f}=\frac{\left(k n_{t} C_{p}^{t} T_{h}+n_{h} C_{p}^{h} T_{h}\right)+k n_{t} C_{p}^{t} T_{t}-k n_{t} C_{p}^{t} T_{h}}{k n_{t} C_{p}^{t}+n_{h} C_{p}^{h}} \\
& T_{f}=\frac{n_{h} C_{p}^{h} T_{h}+k n_{t} C_{p}^{t} T_{t}}{k n_{t} C_{p}^{t}+n_{h} C_{p}^{h}} \\
& T_{f}=\frac{k n_{t} C_{p}^{t} T_{t}+n_{h} C_{p}^{h} T_{h}}{k n_{t} C_{p}^{t}+n_{h} C_{p}^{h}}
\end{aligned}
$$

Part 3: Determine the final pressure by conservation of mass. The number of moles of gas contained in the headspace after the release is the sum of the moles of gas in the headspace before the release and moles of gas released from the waste.

where

$$
\mathrm{n}_{\mathrm{f}}=\mathrm{n}_{\mathrm{h}}+\mathrm{n}_{\mathrm{r}}=\mathrm{n}_{\mathrm{h}}+\mathrm{kn}_{\mathrm{t}}
$$

$$
\begin{aligned}
& \mathbf{k}=\text { fraction of gas released } \\
& \mathbf{n}_{\mathrm{f}}=\text { final moles in the headspace, after release } \\
& \mathbf{n}_{\mathrm{h}}=\text { moles in the headspace before release } \\
& \mathbf{n}_{\mathbf{r}}=\text { moles released }=\mathbf{k n}_{\mathrm{t}} \\
& \mathrm{n}_{\mathrm{t}}=\text { moles trapped gas }
\end{aligned}
$$

From the ideal gas law,

$$
\begin{aligned}
& \mathrm{n}_{\mathrm{f}}=\mathrm{P}_{\mathrm{f}} \mathrm{V}_{\mathrm{f}} / \mathrm{RT}_{\mathrm{f}} \\
& \mathrm{n}_{\mathrm{h}}=\mathrm{P}_{\mathrm{h}} \mathbf{V}_{\mathrm{h}} / \mathrm{RT}_{\mathrm{h}} \\
& \mathrm{kn}_{\mathfrak{t}}=\mathrm{P}_{\mathrm{t}} \mathrm{kV} / \mathrm{RT}_{\mathfrak{t}}
\end{aligned}
$$

Into Equation I.3, substitute Equation I.4, then solve for $P_{f}$.

$$
\begin{aligned}
& P_{f} V_{f} / R T_{f}=n_{h}+k n_{t} \\
& P_{f}=\left(n_{h}+k n_{\mathfrak{l}}\right) R T_{f} / V_{f} \\
& P_{f}=\left(P_{h} V_{h} / R T_{h}+k P_{t} V_{t} / R T_{t}\right) \times R T_{f} / V_{f} \\
& P_{f}=\frac{P_{h} V_{h} / T_{h}+k P_{t} V_{V} / T_{t}}{V_{f}} \times T_{f}
\end{aligned}
$$

Into Equation I.5, substitute $V_{f}=V_{h}+\Delta V=V_{h}+k V_{t}$ from Figure I-1 to get the following:

$$
P_{f}=\frac{P_{h} V_{h} / T_{h}+P_{t} k V / T_{t}}{V_{h}+k V_{t}} \times T_{f}
$$


Into Equation I.6, substitute for $\mathrm{T}_{\mathrm{f}}$ from Equation I.2:

$$
P_{f}=\frac{P_{h} V_{h} / T_{h}+P_{t} k V_{f} / T_{t}}{V_{h}+k V_{t}} \times \frac{k n_{t} C_{p}^{t} T_{t}+n_{h} C_{p}^{h} T_{h}}{k n_{t} C_{p}^{t}+n_{h} C_{p}^{h}}
$$

Once the final headspace pressure is determined from this formula, the overpressure on the HEPA filter can be determined. The overpressure, $P_{0}$, is the difference between barometric pressure outside the tank, $\mathrm{P}_{\mathrm{b}}$, and $\mathrm{P}_{\mathrm{f}}$.

$$
P_{0}=P_{f}-P_{b}
$$

According to the criterion given by Hopkins (1994), $P_{o}$ may not exceed $0.623 \mathrm{kPa}$, (2.5 in. w.g., or 0.364 psi). Substituting from Equation 1.8 gives the following:

$$
\mathrm{P}_{\mathrm{o}}=0.623 \mathrm{kPa}=\mathrm{P}_{\mathrm{f}}-\mathrm{P}_{\mathrm{b}}
$$

Into Equation I.9, substitute for $P_{f}$ from Equation I.7:

$$
\begin{aligned}
P_{o} & =0.623 \mathrm{kPa} \\
& =\left(\begin{array}{lll}
\mathrm{P}_{h} V_{h} / T_{h}+P_{t} k V_{d} T_{t} & \times \frac{k n_{t} C_{p}^{t} T_{t}+n_{h} C_{p}^{h} T_{h}}{V_{h}+k V_{t}} & \frac{k n_{t} C_{p}^{t}+n_{h} C_{p}^{h}}{l}
\end{array}\right]-P_{b}
\end{aligned}
$$

This equation can be solved for $\mathrm{k}$. However; the solution is too long to present here. ${ }^{1}$ On the other hand, an approximation which gives results within about $1 \%$ of the actual value for $k$ can be derived by assuming $C_{p}^{t}$ is equal to $C_{p}^{h}$. Substituting $C_{p}^{h}$ for $C_{p}^{t}$ in Equation 1.10 and simplifying gives Equation I.11:

$$
\begin{aligned}
& P_{o}=0.623 \mathrm{kPa} \\
& =\left(\frac{P_{h} V_{h} / T_{h}+P_{t} k V_{d} / T_{t}}{V_{h}+k V_{t}} \times \frac{k n_{t} C_{p}^{h} T_{t}+n_{h} C_{p}^{h} T_{h}}{k n_{t} C_{p}^{h}+n_{h} C_{p}^{h}}\right) \cdot P_{b}
\end{aligned}
$$

Factoring and canceling $\mathrm{C}_{\mathrm{p}}^{\mathrm{h}}$ gives:

$$
P_{o}=\left(\frac{P_{h} V_{h} / T_{h}+P_{t} k V_{f} / T_{t}}{v_{h}+k V_{t}} \times \frac{k n_{t} T_{t}+n_{h} T_{h}}{k n_{t}+n_{h}}\right)^{-P_{b}}
$$

1 A simple way to determine the value of $k$ is to set up Equation $I .10$ in an Excelrm spreadsheet and use "Goal Seek" to determine the value of $k$. 
Rearranging the first numerator gives:

$$
P_{o}=\left(\frac{k P_{t} V / T_{t}+P_{h} V_{h} / T_{h}}{V_{h}+k V_{t}} \quad \frac{k n_{t} T_{t}+n_{h} T_{h}}{k n_{t}+n_{h}}\right)^{-P_{b}}
$$

Substituting $\mathrm{nR}$ for $\mathrm{PV} / \mathrm{T}$ gives:

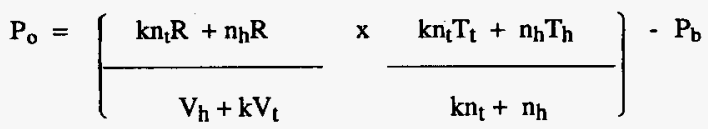

Rearranging and canceling like terms gives:

$$
\begin{aligned}
P_{0} & =\left[\frac{\left(k n_{t}+n_{h}\right) R}{V_{h}+k V_{t}} \times \frac{k n_{t} T_{t}+n_{h} T_{h}}{k n_{t}+n_{h}}\right]-P_{b} \\
& =\frac{R\left(k n_{t} T_{t}+n_{h} T_{h}\right)}{V_{h}+k V_{t}}-P_{b}
\end{aligned}
$$

Substituting PV/R for $\mathrm{nT}$ gives:

$$
\begin{aligned}
P_{0} & =\frac{R\left(k P_{t} V_{t} / R+P_{h} V_{h} / R\right)}{V_{h}+k V_{t}}-P_{b} \\
& =\frac{k P_{t} V_{t}+P_{h} V_{h}}{V_{h}+k V_{t}}-P_{b} \\
& =0.623 \mathrm{kPa}=\frac{k P_{t} V_{t}+P_{h} V_{h}}{V_{h}+k V_{t}}-P_{b}
\end{aligned}
$$

Solving for $\mathbf{k}$ gives the following:

$$
k=\frac{-V_{h}\left(P_{h}-P_{b}-P_{0}\right)}{V_{t}\left(P_{t}-P_{b}-P_{0}\right)}=\frac{-V_{h}\left(P_{h}-P_{b}-0.623\right)}{V_{t}\left(P_{t}-P_{b}-0.623\right)}
$$

When $C_{p}^{t}$ and $C_{p}^{h}$ are equal, there is no difference between the results calculated using Equation $\mathrm{I} .10$ and I.11. However, in bounding calculations, $\mathrm{C}_{\mathrm{p}}^{\mathrm{t}}$ and $\mathrm{C}_{\mathrm{p}}^{\mathrm{h}}$ are not equal, and the value of $k$ approximated with Equation $I .11$ can be as much as 3 to $4 \%$ higher.

The bounding case involves a trapped gas mixture with the highest specific heat, that is, $97 \% \mathrm{~N}_{2} \mathrm{O}$ and $3 \% \mathrm{H}_{2} \mathrm{O}$. Its specific heat is $38.3 \mathrm{~J} / \mathrm{mol}-{ }^{\circ} \mathrm{C}(0.97 \times 38.45+0.03 \times 33.9)$. 
For a plume containing $97 \% \mathrm{H}_{2}$ and $3 \% \mathrm{H}_{2} \mathrm{O}$, the specific heat is $29.0 \mathrm{~J} / \mathrm{mol}-{ }^{\circ} \mathrm{C}(0.97 \mathrm{x}$ $28.82+0.03 \times 33.9$ ).

If overpressurization would require a release fraction greater than 0.25 (may be larger for DSTs), the tank's HEPA filter cannot be overpressurized, as explained at the beginning of Section I-3.1. On the other hand, if the calculation shows that the HEPA can be overpressurized by a release fraction of less than or equal to 0.25 , further analysis is required.

\section{I-3.1.3 Further Evaluation}

For tanks that fail this quick screen, a more comprehensive evaluation can be done to remove the excess conservatism from the estimate. The most conservative of the three assumptions is that the release of trapped gas from the waste is instantaneous, which means the overpressurization takes place instantly. In fact, a release takes place over a time interval ranging from a few minutes to several hours. It may be possible to use release data to estimate the effect of this delay on tanks.

Moreover, for DSTs it may be possible, by plotting bounding pressure pulse vs. release volume, to determine a relationship such as that shown in Figure I-3, and to use this relationship plus a safety margin as a predictor of the maximum pressure pulse in other tanks. On the other hand, if insufficient information is available, it may not be possible to remove the excess conservatism.

Figure 1-3. Pressure Pulse vs. Release Volume.

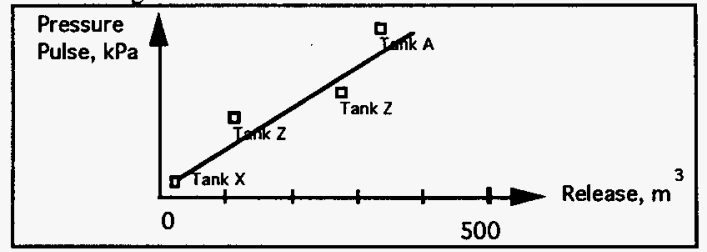

\section{I-4.0 REFERENCES}

DOD, 1988, Filters, Particulate (High-Efficiency Fire Resistant), Mil-F-51068F, U.S. Department of Defense.

Heard, F. J., 1995, Rev 0, Waste Tank 241-SY-101 Dome Air Space and Ventilation System Response to a Flammable Gas Plume Burn, WHC-SD-WM-ER-515, Rev. 0, Westinghouse Hanford Company, Richland, Washington. 
WHC-SD-WM-TI-724, Rev. 1

ATTACHMENT J

METHODOLOGY REVIEW 
This page intentionally left blank 
On December 5 and 6, 1995, a committee co-chaired by D. M. Ogden and P. U. Peistrup reviewed the methodology presented in this document. The report of their review is presented on pages J-4 through J-10 of this attachment. Following their report is the response of the evaluation team to the review comments.

\section{REFERENCES}

Hopkins, J. D., 1994, Criteria for Flammable Gas Watch List Tanks, WHC-EP-0702, Rev. 0, Westinghouse Hanford Company, Richland, Washington.

Shepard, C. L., C. W. Stewart, J. M. Alzheimer, G. Terrones, G. Chen, and N. E. Wilkins, 1995, In Situ Determination of Rheological Properties and Void Fraction: Hanford Waste Tank 241-SY-103, PNL-10865, Pacific Northwest National Laboratory, Richland, Washington. 
From: Plant Systems Safety Basis/TWRS Safety Basis

74010-95-DMO-009

Phone: $\quad 376-0438$ H0-34/373-3119 57-14

Date: December 12, 1995

Subject: REVIEW OF THE FLAMMABLE GAS EVALUATIONS

To:

A. M. Umek

S7-81

cc:
W. B. Barton
R2-11
T. R. Beaver
H0-34
G. R. Franz
S7-81
G. D. Johnson
S7-15
N. W. Kirch
R2-11
E. J. Lipke S7-14
F. A. Schmittroth HO-35
E. R. Siciliano HO-31
J. P. Sloughter R2-54
DMO File/LB
PEP File/LB

References: (1) Whitney, P., 1995, Screening the Hanford Tanks for Trapped Gas, PNL-10821, Pacific Northwest Laboratory, Richland, Washington.

(2) Hopkins, J. D., 1994, Criteria for Flammable Gas Watch List Tanks, WHC-EP-0702, Rev. 0, Westinghouse Hanford Company, Richland, Washington.

(3) Hopkins, J. D., 1995, Methodology for Flammable Gas Evaluations, WHC-SD-WM-TI-724, Rev. 0, REVIEW DRAFT, Westinghouse Hanford Company, Richland, Washington.

(4) WHC, Flammable Gas Evaluation, WHC-SD-WM-ER-526, Rev. 0, DRAFT, Westinghouse Hanford Company, Richland, Washington.

\section{INTRODUCTION}

A screening of the Hanford high level waste tanks was performed by Pacific Northwest National Laboratory (PNNL) (Reference 1) using a barometric pressure method. The 38 tanks not previously identified on the Flammable Gas Watch List were subsequently evaluated against existing flammable gas criteria (Reference 2). Per your request, an independent peer review of this flammable gas evaluation has been conducted. The scope of the review included the methodology for the evaluations (Reference 3 ), the application of the methods (Reference 4), and the recommendation of tanks to be placed on the Flammable Gas Watch list. The review was conducted in two phases. The first phase included a detailed evaluation of the screening methods including quality assurance reviews and independent statistical and thermal 
hydraulic analyses. A two-day formal review was then performed for a 11 aspects of the flammable gas evaluations. The review team members included:

\author{
Phi1 Peistrup(Co-chairman) \\ Don Ogden (Co-chairman) \\ Al Neuls \\ Marvin Thurgood \\ Frank Schmittroth \\ Tom Beaver
}

\author{
Westinghouse Hanford Company \\ Westinghouse Hanford Company \\ Los Al amos National Laboratory \\ John Marvin, Inc. \\ Westinghouse Hanford Company \\ Westinghouse Hanford Company
}

Martin PIys, Fauske \& Associates, Inc, reviewed the referenced documents and provided comments but did not participate in the formal review.

A summary of the review teams evaluation is provided below followed by a detailed discussion of the review.

\section{SUMMARY}

The review team believes that the screening methods identified in Reference 3 and applied in Reference 4 , with some recomended modifications, are suitable tools for evaluating the potential for gas generation, storage and release to the tank dome space. The methods selected to quantify trapped gas are valid for this purpose. The conservatism of the screening methods and the poor quality of some of the data avallable for evaluation can lead to false positive results for individual screening methods. However, the review team believes that when the screening methods are properly applied, there should be consistency in the results. For these reasons, it is recommended that a waste tank not be considered for the Flammabie Gas Watch List unless it fails two-out-of-three evaluation methods. Twenty tanks are recommended by the review team for the Flammable Gas Watch List based on this approach. Fifteen of the twenty waste tanks failed three-out-of-three screening methods.

\begin{tabular}{|c|c|c|}
\hline A103 & AW104 & AY101 \\
\hline BX107 & BY101 & BY102 \\
\hline BY103 & BY105 & BY109 \\
\hline C104 & C105 & S101 \\
\hline S102 & S103 & S106 \\
\hline S107 & S109 & TX112 \\
\hline TX115 & U102 & \\
\hline
\end{tabular}

The review team concurs that the Quick Screen methodology as applied is sufficiently conservative for the purpose of quickly identifying waste tanks requiring no further consideration or screening. However, all tanks which 
Page 3

December 12, 1995

fail the Quick Screen should be evaluated by the full suite of evaluation methods.

The team was presented with proposed revisions to the flammable gas criteria based on $100 \%$ of the Lower Flammability Limit (LFL) but did not attempt to evaluate revised criteria or review specific controls for flammable gas tanks. However, many assumptions in the methodology depend on this criteria and, if it is changed, then the review team believes certain assumptions in the methodology will need to be reevaluated.

The review team believes that there is reasonable evidence to show that all waste tanks generate and trap flammable gas to some degree and that appropriate flammable gas controls should be applied to all tanks during intrusive waste activities.

A discussion of the review teams evaluation follows.

\section{BAROMETRIC PRESSURE METHOD}

The review team concurs with the overall methodology of the barometric pressure method. This method is based on correlating measured changes in tank waste level to changes in atmospheric pressure through statistical analyses of the data (Reference $l$ and 3 ). It is believed to be adequately conservative although individual assumptions including gas release fraction and gas location may not be conservative for all situations and some gas trapping mechanisms can result in an underestimate of the trapped gas volume (false negative). The overall conservatism of the method is demonstrated by the following. The estimated gas volumes are based on a slope estimate which bounds $75 \%$ of the calculated slopes. The Monte Carlo method presented to the review team was used to quantify the uncertainties in the analytical parameters and showed that the $75 \%$ slope estimate generally compared to the Monte Carlo method at the $99 \%$ confidence 1evel. Schmittroth and Beaver presented statistical analyses performed by using independent statistical analyses tools. Their analyses compared well with void fraction data for three waste tanks and demonstrated that the 75th percentile slope is conservative by a factor of $50 \%$ to $100 \%$. In principle the $75 \%$ point estimate and the Monte Carlo method at the $99 \%$ confidence levels are both acceptable approaches. However, the Monte Carlo uncertainty distribution for the gas release fraction should peak near the assumed $25 \%$ release fraction and the uncertainty in the gas overpressure should be included. The review team believes that these refinements of the model are required.

The application of the barometric pressure method to tanks which have been saltwell pumped may lead to an overly conservative estimate of trapped gas or a false positive result. In these tanks the method relies on interstitial liquid level measurements which are currently of poor quality. In addition the liquid level increase observed in some of these tanks may be due to liquid draining rather than flammable gas storage. The review team believes that the three methods should show a consistency of results and recommends that no tank be placed on the flammable Gas Watch List unless it fails two-out-of-three of the methods. For tanks with poor quality level data, an attempt should be made to collect data which can remove the large uncertainty in the estimate of trapped gas volume. 


\section{TANK LEVEL METHOD}

The review team believes that the tank level method described in Reference 2 is a reasonable and valid method. The stated methodology takes into account factors that may influence the liquid level other than gas accumulation. These include loses due to evaporation, compaction, leakage and pumping and additions due to in-leakage, moisture absorption, and crystal expansion. The review team found, however, that these contributing factors have not been adequately accounted for in the current evaluation and the results are therefore of limited value. Thurgood presented results of his independent analyses and application of the tank level method. His work used reasonable and conservative assumptions to estimate tank ventilation flows and the resulting evaporation. The Thurgood results were very consistent with the barometric pressure method and a modified steady-state method. The consistency between these methods is a result of improved ventilation flow and evaporation estimates. It should be noted that the initial gas volume has not been accounted for in the application of this method. The estimates of the ventilation flow rates are conservative and will generally compensate for small amounts of initial gas. However, future applications of this method should consider this possible non-conservatism. The review team recommends incorporation of the Thurgood enhancements to the tank level method.

The current methodology document recommends that this method be used only when the surface level measurement (or ILL level measurement) shows an increase in time. Because evaporation can mask the effect of gas accumulation even in tanks where the measured level is decreasing, it is recommended that the method be applied to all tanks where the liquid level is near or above the solids level. We believe that it is not appropriate to apply these estimates of evaporation to tanks which have liquid levels that are a significant distance below the waste level since evaporation in these tanks probably comes from damp solids above the gas trapping saturated 1 iquid level which is lower in the waste and do not affect the liquid level that is affected by gas accumulation. However, for these situations it is appropriate to apply the tank level method without evaporation.

\section{STEADY-STATE METHOD}

The original purpose of this evaluation was to determine the potential for exceeding $25 \%$ of the LFL in the dome space from steady state release of generated gas, not episodic or accidental releases. As impiemented, the evaluation used a combination of predicted and measured values for dome space gas concentration. The results were inconsistent and of little value for screening purposes. Thurgood showed that by using the ventilation flow estimates from his revised tank level method, the steady-state method resulted in consistent estimates of dome space gas concentrations. These results also compared very well with measured values where they existed and demonstrated that flammable gas concentrations would not be expected to exceed $25 \%$ of the LFL even for tanks with high generation rates and passive ventilation. Thus, the method is of little value for screening purposes. The real value in the steady-state method is the estimate of gas generation rate. 
The review team recommends that the steady-state method should use the conservative barometric breathing rate when calculating flammable gas concentrations. The results will then indicate the gas generation potential of the tank. The gas concentrations from the revised steady-state method should not be added to the other methods. The value of using the revised steady state method (which could be called the gas generation method) is seen for tanks Iike AP107 and AZ101. The modified steady-state method predicts a very high gas generation rate for these tanks. The other methods suggest that they have little potential for trapping the gas, and therefore are not recommended for the Flammable Gas Watch List. However, future operations which may change the level of settled solids and thus the tanks ability to trap gas, may require a flammable gas screening.

It should also be noted that when the steady-state method is applied as suggested, the results are consistent with the other methods. Thus, if one of the methods is not available because of poor data, two viable methods remain to screen the tank.

\section{QUICK-SCREEN METHOD}

The purpose of the quick screen is to eliminate tanks from further analysis. This method assumes that $7.35 \%$ of the total waste volume is compressed gas (based on SY-101 experience) which is released to the dome space $1100 \%$ release fraction). If the resulting concentrations is 1 ess than $25 \%$ of the LFL, the tank passes the screen and is not considered for further evaluation. The review team concurs with this approach if the total waste volume is used for the analyses, not the less conservative wet solids volume. This method appropriately eliminates about 40 tanks with low volumes from further evaluation.

\section{APPLICATION OF METHODS}

The four methods that are used in the current methodology are: (1) the quick screen, (2) the steady-state method, (3) the tank level method and (4) the barometric pressure method. It is understood that all the methods are conservative and rely on tank data which can be of poor quality with large uncertainty. Furthermore, the methods should give consistent results if they are properly applied. The review team believes that one method by itself is insufficient evidence to place a tank on the Flammable Gas Watch List. There should be consistent evidence from at least two of the three methods that the tank meets the Flammable Gas Watch List criteria. The review team recommends that the modifications to the tank level and steadystate method discussed previously be implemented and that a tank should be considered for the Flammable Gas Watch List if it fails two-out-of three of the methods. We note, however, that the gas generation potential should be noted for tanks in which this parameter exceeds $25 \%$ of the LFL. since a change in the operating status or waste loading of tanks could result in a flammability hazard.

\section{FLAMMABLE GAS WATCH LIST CRITERIA AND CONTROLS}

The review team was presented with a revised $\mathrm{Flammable} \mathrm{Gas} \mathrm{Watch} \mathrm{List}$ criteria which would utilize $100 \%$ of the LFL as its basis. The team did not attempt to evaluate this revised criteria or review specific controls for 
flammable gas tanks. However, the following cautions are offered. The criteria chosen for $F$ lammable Gas Watch List determination should consider the degree of conservatism in the analytical methods being used and the uncertainty of the data available to perform the calculations. The four methods defined in Reference 2 do not consider the in situ ignition of flammable gas or the ignition of hydrogen in local plumes where the gas is escaping from the waste. The conservatism of the methodology relies on maintaining the average concentration of flammable gas in the tank dome at a safe level below the lower flammability limit. This concentration has currently been established to be $25 \%$ of the LFL. It is the opinion of the review team that many assumptions in the methodology depend on this criteria and, if the criteria is changed, then certain assumptions in the methodology need to be reevaluated.

If the entire body of work documented in References 1,3 and 4 are considered as a whole, a reasonable person can conclude that all waste tanks produce flammable gas and are capable of trapping it to some degree. The review team recommends that all activities in waste tanks be conducted in accordance with NFPA standards recognizing that releases from unexpected mechanisms may occur, particularly for waste intrusive activities.

\section{RECOMMENDATION FOR FLAMMABLE GAS WATCH LIST}

Reference 4 evaluated 44 waste tanks. Only the 38 tanks which. failed the Whitney Screen were considered by the teams review. The review team used the revisions to the tank level and steady-state methods presented by Thurgood and a two-out-of-three criteria to evaluate the tanks for the Flammable Gas Watch List. It should be noted that $75 \%$ of the tanks recommended for the $\mathrm{Flammable} \mathrm{Gas} \mathrm{Watch} \mathrm{List} \mathrm{failed} \mathrm{all} \mathrm{three} \mathrm{screening}$ methods.

Tanks AW106 and BY106 are excluded from the list and require reevaluation because of recent pumping activities in the tank.

The committee recommends the following tanks for the Flammable Gas Watch List based upon a careful consideration of the evaluation methods and applications and believes the list reasonably represents the tanks which could have "serious potential for release of high level waste."

\begin{tabular}{|c|c|c|}
\hline A103 & AW104 & AY101 \\
\hline BX107 & BY101 & BY102 \\
\hline BY103 & BY105 & BY109 \\
\hline C104 & C105 & S101 \\
\hline S102 & S103 & S106 \\
\hline S107 & S109 & TX112 \\
\hline TX115 & U102 & \\
\hline
\end{tabular}


A. M. Umek

74D10-95-DM0-009

Page 7

December 12, 1995

The review team recommends that all waste tanks should be evaluated using the four screening methods with the recommended modifications.
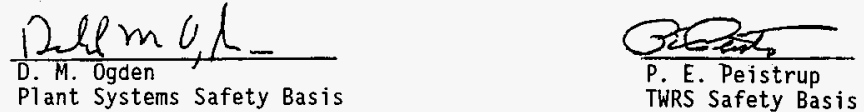
Table J.1. Response to Review Comments (4 sheets)

\begin{tabular}{|c|c|c|c|}
\hline No. & Location & Recommendation/Comment & Response \\
\hline 1 & $\begin{array}{l}\text { P. 3, } \\
\text { Baro } \\
\text { Press } \\
\text { Method }\end{array}$ & $\begin{array}{l}\text {... assumptions including } \\
\text { gas release fraction and gas } \\
\text { location may not be } \\
\text { conservative for all } \\
\text { situations, and some gas } \\
\text { trapping mechanisms can } \\
\text { result in underestimate of the } \\
\text { trapped gas volume. }\end{array}$ & $\begin{array}{l}\text { a. Gas release fraction. This is a valid issue for the } \\
\text { deterministic calculation. PNNL is investigating } \\
\text { this issue. Meanwhile, preliminary indications } \\
\text { are that the assumptions used are conservative. } \\
\text { The evaluation methodology will be modified if } \\
\text { PNNL's results determine the assumptions are } \\
\text { not conservative. } \\
\text { b. Gas location. This needs further study. A } \\
\text { videotape of recent 1/75th-scale gas-release } \\
\text { experiments by P. A. Gauglitz show that gas has } \\
\text { a tendency to continually migrate upwards in } \\
\text { solids waste. Intuitively, it seems that for tanks } \\
\text { which have never had a major gas release (most } \\
\text { or all SSTs), the center of gas would be higher } \\
\text { than for a tank which has had a release recently. } \\
\text { In any case, sensitivity analysis shows that } \\
\text { varying the gas location has little impact on the } \\
\text { \% LFL. Because the location is already assumed } \\
\text { to be deep in the tank, the assumed gas depth } \\
\text { can only be increased a small amount and } \\
\text { therefore can only raise the pressure on the gas, } \\
\text { and the trapped-gas volume, by a few percent } \\
\text { (e.g., 2-5\%) in most cases. } \\
\text { c. Gas-trapping mechanisms. This needs further } \\
\text { study. If trapping occurs via certain } \\
\text { mechanisms, the gas volume can be } \\
\text { underestimated, but it appears that the factors } \\
\text { that cause the gas to be underestimated would } \\
\text { also cause the fraction released to be smaller than } \\
0.25 ; \text { e.g., a high yield strength for sludge } \\
\text { could delay gas expansion caused by decreasing } \\
\text { barometric pressure, but the high yield strength } \\
\text { is likely to decrease the fraction released at any } \\
\text { one time. }\end{array}$ \\
\hline 2 & $\begin{array}{l}\text { P. 3, } \\
\text { Baro } \\
\text { Press } \\
\text { Method, } \\
\text { para 1 }\end{array}$ & $\begin{array}{l}\text {... Monte Carlo uncertainty } \\
\text { distribution for the gas } \\
\text { release fraction should peak } \\
\text { near the } 25 \% \text { release } \\
\text { fraction... (continued on } \\
\text { next page) }\end{array}$ & $\begin{array}{l}\text { Examination of data for DSTs which have } \\
\text { periodic releases (except for tank SY-101, which } \\
\text { has been mitigated) shows that no DST has had a } \\
\text { release fraction of more than } 0.21 \text { (Shepard, et al. } \\
\text { 1995). SSTs are expected to have lower release } \\
\text { fractions than DSTs. (continued on next page) }\end{array}$ \\
\hline
\end{tabular}


Table J.1. Response to Review Comments (4 sheets)

\begin{tabular}{|c|c|c|c|}
\hline & Location & Recommendation/Comment & Response \\
\hline 2 & $\begin{array}{l}\text { P. 3, } \\
\text { Baro } \\
\text { Press } \\
\text { Method, } \\
\text { para 1 }\end{array}$ & $\begin{array}{l}\text {.. Monte Carlo uncertainty } \\
\text { distribution for the gas } \\
\text { release fraction should peak } \\
\text { near the } 25 \% \text { release } \\
\text { fraction... (continued from } \\
\text { previous page) }\end{array}$ & $\begin{array}{l}\text { This proposed distribution would be very } \\
\text { conservative and not realistic. For example: } \\
\text { For } 58 \% \text { of EGRs, the release fraction would } \\
\text { exceed } 0.25 \text {. } \\
\text { For } 50 \% \text { of EGRs, the fraction would be } \\
\text { higher than } 0.29 \text {. } \\
\text { For } 10 \% \text {, the fraction would exceed } 0.51 \text {. } \\
\text { For } 1 \% \text {, the fraction would exceed } 0.70 \text {. } \\
\text { On the other hand, if the distribution were just } \\
\text { for a particular scenario-say, a DST during a } \\
\text { magnitude } 8 \text { earthquake- - the distribution should } \\
\text { be shifted to the right. }\end{array}$ \\
\hline 3 & $\begin{array}{l}\text { P. 3, } \\
\text { Baro } \\
\text { Press } \\
\text { Method, } \\
\text { para 1 }\end{array}$ & $\begin{array}{l}\text {... the uncertainty in the gas } \\
\text { overpressure should be } \\
\text { included. }\end{array}$ & $\begin{array}{l}\text { The effect on barometric analysis appears to be } \\
\text { minor regarding variations between pressure at the } \\
\text { Hanford Meteorological Station and the tank, as } \\
\text { discussed in Section } 8.7 \text { of this methodology } \\
\text { document. } \\
\text { One element of pressure on the gas is surface } \\
\text { tension, which has been addressed in Section } 8.1 \\
\text { and found not to be significant. Uncertainties } \\
\text { related to variations in solids yield stress are not } \\
\text { addressed in the document but are being } \\
\text { investigated by PNNL. } \\
\text { The effect appears to be more significant } \\
\text { regarding the practice of not recording the exact } \\
\text { time when a manual surface level readings is } \\
\text { taken. This means there is some uncertainty in the } \\
\text { pressure at the time of the surface level reading. } \\
\text { This issue still needs to be resolved. } \\
\text { Meanwhile, the review committee found that } \\
\text { using the } 75 \text {-percentile barometric slope gives } \\
\text { conservative values for gas volumes. }\end{array}$ \\
\hline 4 & $\begin{array}{l}\text { P. 3, } \\
\text { Baro } \\
\text { Press } \\
\text { Method, } \\
\text { para } 2\end{array}$ & $\begin{array}{l}\text {... the three methods } \\
\text { should show a consistency } \\
\text { of results and recommends } \\
\text { that no tank be placed on } \\
\text { the FGWL unless it fails } \\
\text { two-out of-three of the } \\
\text { methods. }\end{array}$ & $\begin{array}{l}\text { It is desirable that results be consistent. } \\
\text { However, this is not always possible, perhaps } \\
\text { owing to the poor quality of surface level data } \\
\text { available. Moreover, a tank might pass the surface } \\
\text { level evaluation simply because a leak from the } \\
\text { tank masks a surface-level rise, while the tank fails } \\
\text { analysis based on barometric slope. } \\
\text { The evaluation team does not recommend } \\
\text { whether a tank be placed on the Flammable Gas } \\
\text { Watch List. It simply reports evaluation results. } \\
\text { Note, however, that the criteria document for } \\
\text { FGWL (Hopkins 1994) requires that if a tank fail } \\
\text { any one of the criteria-for example, the steady- } \\
\text { state criterion or the episodic-release criterion- } \\
\text { that it be placed on the FGWL. This proposal will } \\
\text { be considered in any future revision to the criteria. }\end{array}$ \\
\hline
\end{tabular}


Table J.1. Response to Review Comments (4 sheets) \begin{tabular}{|l|l|l|l|}
\hline No. & Location & Recommendation/Comment & Response \\
\hline
\end{tabular}

\begin{tabular}{|c|c|c|c|}
\hline 5 & $\begin{array}{l}\text { P. 3, } \\
\text { Baro } \\
\text { Press } \\
\text { Method, } \\
\text { para 2 }\end{array}$ & $\begin{array}{l}\text { For tanks with poor quality } \\
\text { level data, an attempt should } \\
\text { be made to collect data } \\
\text { which can remove the large } \\
\text { uncertainty in the estimate } \\
\text { of trapped gas volume. }\end{array}$ & Agreed. This has been done for some tanks. \\
\hline 6 & $\begin{array}{l}\text { P. 4, } \\
\text { Tank } \\
\text { Level } \\
\text { Method, } \\
\text { para 1 } \\
\text { and } \\
\text { para } 2\end{array}$ & $\begin{array}{l}\ldots \text { the initial gas volume } \\
\text { has not been accounted } \\
\text { for.... ...future } \\
\text { applications of this } \\
\text { method should consider } \\
\text { this possible noncon- } \\
\text { servatism. The review } \\
\text { team recommends } \\
\text { incorporation of the } \\
\text { Thurgood enhancements } \\
\text { to the tank level method. } \\
\text {.. It is recommended that } \\
\text { the method be applied to } \\
\text { all tanks where the liquid } \\
\text { level is near or above the } \\
\text { solids level. }\end{array}$ & $\begin{array}{l}\text { Most of the evaluations have accounted for the } \\
\text { initial gas volume, However, for a few tanks } \\
\text { evaluated in 1995, this was not done. } \\
\text { The Thurgood enhancements to the tank level } \\
\text { method were incorporated into the evaluations for } \\
\text { tanks with a liquid surface. }\end{array}$ \\
\hline 7 & $\begin{array}{l}\text { P. 5, } \\
\text { Steady- } \\
\text { State } \\
\text { Method, } \\
\text { first para } \\
\text { on page } 5\end{array}$ & $\begin{array}{l}\text { The review team } \\
\text { recommends that the } \\
\text { steady state method } \\
\text { should use the } \\
\text { conservative barometric } \\
\text { breathing rate when } \\
\text { calculating flammable gas } \\
\text { concentrations [and not } \\
\text { take into account any } \\
\text { mechanical ventilation]. } \\
\text { The results will then } \\
\text { indicate the gas generation } \\
\text { potential of the tank. The } \\
\text { gas concentration from the } \\
\text { revised steady state } \\
\text { method should not be } \\
\text { added to the other } \\
\text { methods. (Emphasis } \\
\text { added by underlining.) }\end{array}$ & $\begin{array}{l}\text { The recommended practice is more } \\
\text { conservative than required by Hopkins } 1994 \text {, } \\
\text { Appendix E, para } 4.8 \text {, "Worst Case Calculation - } \\
\text { Steady-State Concentration." On the other hand, } \\
\text { the recommendation is consistent with Appendix } \\
\text { E, para } 6.0 \text {, "OTHER," which requires } \\
\text { evaluating the tank for "other potential hazards." } \\
\text { For tanks evaluated since January 1996, the } \\
\text { Excel' }{ }^{\text {TM }} \text { spreadsheet calculated and reported the } \\
\text { steady-state concentration without mechanical } \\
\text { exhaust. However, the concentration was not } \\
\text { considered in the decision-making process. } \\
\text { The recommended calculation is appropriate } \\
\text { for Safety Analysis work to identify tanks which } \\
\text { need ventilation and Technical Safety } \\
\text { Requirements-level controls on the ventilation } \\
\text { system. }\end{array}$ \\
\hline 8 & $\begin{array}{l}\text { P. 5, } \\
\text { Applica- } \\
\text { tion of } \\
\text { Methods }\end{array}$ & $\begin{array}{l}\text { The review team } \\
\text { recommends that the } \\
\text { modifications to the tank } \\
\text { level ... discussed } \\
\text { previously be implemented }\end{array}$ & See item 6. \\
\hline
\end{tabular}


Table J.1. Response to Review Comments (4 sheets)

\begin{tabular}{|l|l|l|l|l|}
\hline No. & Location & Recommendation/Comment & Response \\
\hline
\end{tabular}

\begin{tabular}{|l|l|l|l|}
\hline 9 & $\begin{array}{l}\text { P. 5, } \\
\text { Applica- } \\
\text { tion of } \\
\text { Methods }\end{array}$ & $\begin{array}{l}\text { The review team } \\
\text { recommends that the } \\
\text { modifications to the ... } \\
\text { steady state method } \\
\text { discussed previously be } \\
\text { implemented... the gas } \\
\text { generation potential should } \\
\text { be noted for tanks in which } \\
\text { this parameter exceeds 25\% } \\
\text { of the LFL since a change in } \\
\text { the operating status or waste } \\
\text { loading to tanks could result } \\
\text { in a flammability hazard. } \\
\text { Emphasis added by } \\
\text { underlining.) }\end{array}$ & See item 7. \\
\hline 10 & $\begin{array}{l}\text { P. 5, } \\
\text { Applica- } \\
\text { ton of } \\
\text { Methods }\end{array}$ & $\begin{array}{l}\text { The review team } \\
\text { recommends that ... a tank } \\
\text { should be considered for the } \\
\text { Flammable Gas Watch List } \\
\text { if it fails two-out-of-three of } \\
\text { the methods. }\end{array}$ & See item 4. \\
\hline 12 & $\begin{array}{l}\text { The following cautions are } \\
\text { offered. ... The four } \\
\text { methods .... do not consider } \\
\text { in situ ignition of flammable } \\
\text { gas or the ignition of } \\
\text { hydrogen in local plumes } \\
\text { F... } \\
\text { mable } \\
\text { Gas } \\
\text { Watch } \\
\text { List and } \\
\text { Controls }\end{array}$ & $\begin{array}{l}\text { a. In situ ignition. The evaluation team is not } \\
\text { evaluating the possibility of in situ ignition. }\end{array}$ & $\begin{array}{l}\text { Plume burn. Further study is required on this } \\
\text { issue. Analysis based Heard's (1995) small- } \\
\text { burn model results is being done to see if a } \\
\text { plume burn is credible. If so, tanks must be } \\
\text { evaluated against the plume burn criteria. Until } \\
\text { then, tanks passing the other screens should not } \\
\text { be considered free of plume burn hazard. }\end{array}$ \\
\hline
\end{tabular}


WHC-SD-WM-TI-724, Rev. 1

\section{ATTACHMENT K}

\section{REVISED TANK LEVEL METHOD FOR FLAMMABLE GAS EVALUATION}

K-1 
This page intentionally left blank 


\title{
REVISED TANK LEVEL METHOD FOR
}

\section{FLAMMABLE GAS EVALUATION}

by

\author{
M.J. Thurgood \\ D.M. Ogden
}

John Marvin, Inc.

WHC

\section{INTRODUCTION.}

A rising liquid level is one of the parameters that has been recognized to indicate trapped gas in the 1990 Flammable Gas Watch List (FGWL) evaluation and is being used by the current evaluation team as a method for determining the volume of trapped gas in waste tanks [Ref 1]. While the current evaluation team has recognized the importance of the effect of evaporation on liquid level, hence, on the estimate of the volume of trapped gas in the waste tank, time limitations have not permitted them to incorporate this effect into their spread sheet calculation for estimating the potential flammable gas concentration in the tank dome resulting from a gas release event (GRE) in a tank.

As a part of a review that we have been asked to conduct on the Methodology for Flammable Gas Evaluations, we have developed an approximate method for estimating the level change that should occur within a tank due to evaporation. This estimate of expected level change can then be compared with the measured level change to obtain an estimate of the volume of trapped gas in the waste. The methods and assumptions developed in Reference 1 are then used to determine the fraction of this gas that can be released to the tank dome and the resulting percentage of the lower flammability limit (LFL). 


\section{ESTIMATION OF EVAPORATION RATE.}

The method for estimating the evaporation rate is dependent on the following parameters:

1. Ventilation flow rate.

2. Inlet air temperature and relative humidity.

3. Tank dome atmosphere temperature and relative humidity.

The air inlet temperature has been assumed to be at the yearly average atmospheric temperature for Hanford, $56.3^{\circ} \mathrm{F}$ and the relative humidity of the inlet air is assumed to be 508. The dome atmosphere temperature is assumed to be the yearly average dome temperature where this value is available, otherwise, the slurry temperature given in the spreadsheets of [Ref 1] is assumed to be the dome average temperature.

The ventilation flow rate is estimated using one of three methods :

1. If the tank is ventilated and/or tank ventilation rates have been estimated previously using more sophisticated thermal hydraulic analyses, the known or calculated ventilation flow rates are used to estimate the evaporation rates. Often, the values used for the forced ventilation flows are those given in the spread sheets if better references are not known. In addition, these ventilation flows are limited to be no larger than the flows estimated using method 3 below.

2. If measured values for dome hydrogen concentration are available, the passive ventilation required to 
maintain the tank dome at the measured concentration given the hydrogen generation rates given in the spreadsheets of [Ref 1] can be calculated as:

$Q=R \frac{\left(1-v_{f H 2}\right)}{v_{f H 2}}$

where:

$$
\begin{aligned}
& Q=\text { passive ventilation inflow rate. } \\
& R=\text { Hydrogen generation rate from spreadsheet. } \\
& v_{\mathrm{fH} 2}=\begin{array}{l}
\text { measured volume fraction of hydrogen in the } \\
\text { tank dome. }
\end{array}
\end{aligned}
$$

If flows cannot be determined from method 1 above, then the flow estimate obtained using this method is used to estimate the tank evaporation rate.

3. If no other information is available to provide natural ventilation flows, it is assumed that all of the tank heat load is removed by natural ventilation flow and the flow required to remove this energy is calculated. This is believed to provide a very conservative estimate of ventilation flow and evaporation rate since thermal analyses that have been performed to date indicate that most, if not all, of the heat generated in these passively ventilated tanks can be removed by conduction through the ground [Ref. 2].

The total heat removed from the tank by the ventilation flow is:

$$
q_{T}=q_{A}+q_{S}+q_{E}
$$

where: 


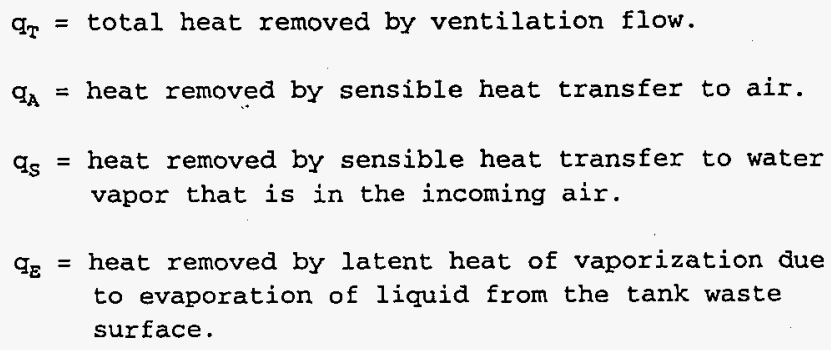
to evaporation of liquid from the tank waste surface.

Each of these quantities can be calculated as follows:

By definition, the relative humidity of the inlet air is:

$$
\phi_{I}=\frac{P_{S I}}{P_{g I}}
$$

where:

$$
\begin{aligned}
\mathrm{P}_{\text {SI }}= & \text { partial pressure of water vapor in the inlet } \\
& \text { flow. } \\
\mathrm{P}_{\mathbf{g I}}= & \begin{array}{l}
\text { saturation pressure of water vapor at the inlet } \\
\text { temperature. }
\end{array}
\end{aligned}
$$

Since the inlet air humidity and temperature are specified quantities, the partial pressure of steam in the inlet flow can be calculated:

$$
P_{S I}=\phi_{I} P_{g I}
$$

The volume fraction of steam in the inlet flow is:

$$
v_{E S I}=\frac{P_{S I}}{P_{\infty}}
$$

where:

$$
P_{\infty}=\text { Atmospheric pressure }
$$

The inlet volumetric flow rate of steam is: 


$$
Q_{S I}=Q_{I} v_{E S I}
$$

where:

$$
Q_{I}=\text { total inlet volumetric flow. }
$$

The inlet volumetric flow rate of dry air is:

$$
Q_{A I}=Q_{I}\left(1-v_{f S I}\right)
$$

The outlet volumetric flow xate of dry air is proportional to the volumetric flow of air in and the ratio of the outlet to inlet air temperatures:

$$
Q_{A O}=Q_{A I} \frac{T_{O}}{T_{I}}
$$

where:

$$
\begin{aligned}
\mathrm{T}_{\mathrm{O}}= & \begin{array}{l}
\text { outlet temperature }=\text { average dome atmosphere } \\
\text { temperature. }
\end{array} \\
\mathrm{T}_{\mathrm{I}}= & \begin{array}{l}
\text { inlet air temperature }=\text { annual average ambient } \\
\text { air temperature. }
\end{array}
\end{aligned}
$$

The outlet volume fraction of steam is:

$$
v_{\text {ESO }}=\phi_{O} \frac{\mathrm{P}_{\mathrm{gO}}}{\mathrm{P}_{\infty}}
$$

where:

$$
\begin{aligned}
\phi_{0}= & \text { outlet relative humidity }=1008 . \\
\mathrm{P}_{\mathrm{go}}= & \text { water vapor saturation-pressure at the outlet } \\
& \text { temperature. }
\end{aligned}
$$

The outlet volume fraction of air in the outlet flow is:

$$
v_{f A O}=\left(1-v_{f S O}\right)
$$

So, the outlet volumetric flow of water vapor is: 


$$
Q_{S O}=Q_{A O} \frac{v_{f S O}}{v_{E A O}}
$$

and the total outlet volumetric flow is:

$$
Q_{0}=Q_{A O}+Q_{S O}
$$

The corresponding mass flow rates are:

$$
\begin{aligned}
& m_{A I}=\frac{P_{\infty}}{R A T I} Q A I \\
& m_{S I}=\frac{P_{\infty}}{R S T I} Q S I \\
& m_{A O}=\frac{P_{\infty}}{R A T O} \text { QAO } \\
& m_{S O}=\frac{P_{\infty}}{R S T O} \text { QSO }
\end{aligned}
$$

where:

$$
\begin{aligned}
& \mathrm{m}_{\mathrm{AI}}=\text { air mass flow rate in. } \\
& \mathrm{m}_{\mathrm{SI}}=\text { water vapor mass flow rate in. } \\
& \mathrm{m}_{\mathrm{AO}}=\text { air mass flow rate out. } \\
& \mathrm{m}_{\mathrm{SO}}=\text { water vapor mass flow rate out. } \\
& \mathrm{R}_{\mathrm{A}}=\text { gas constant for air. } \\
& \mathrm{R}_{\mathrm{S}}=\text { gas constant for water vapor. } \\
& \mathrm{T}_{\mathrm{I}}=\text { inlet temperature. } \\
& \mathrm{T}_{\mathrm{O}}=\text { outlet temperature. } \\
& \mathrm{Q}_{\mathrm{AI}}=\text { partial volumetric flow rate of air in. }
\end{aligned}
$$




$$
\begin{aligned}
& \mathrm{Q}_{S I}=\text { partial volumetric flow rate of water vapor in. } \\
& \mathrm{Q}_{\mathrm{AO}}=\text { partial volumetric flow rate of air out. } \\
& \mathrm{Q}_{\mathrm{SO}}=\begin{array}{l}
\text { partial volumetric flow rate of water vapor } \\
\text { out. }
\end{array}
\end{aligned}
$$

The rate of evaporation is given as:

$$
m_{E}=m_{S O}-m_{S I}
$$

The rate of change in tank liquid level is:

$$
\Delta \text { level }=\frac{m_{E}}{\rho_{1}\left(T_{0}\right) A_{\text {tank }}}
$$

where:

$$
\begin{aligned}
& \rho_{1}\left(T_{0}\right)=\text { density of water at the dome temperature. } \\
& A_{\text {tank }}=\text { cross-sectional area of tank. } \\
& m_{E}=\text { evaporation rate. }
\end{aligned}
$$

The heat removed by each heat removal mechanism is:

Sensible heat to air:

$q_{A}=m_{A I} C_{p A I}\left(T_{O}-T_{I}\right)$

where:

$$
\mathrm{C}_{\mathrm{pAI}}=\text { specific heat of inlet air. }
$$

Sensible heat to inlet water vapor:

$q_{S}=m_{S I}\left(h_{g \circ u t}-h_{g i n}\right)$

where:

$$
h_{\text {gout }}=\text { water vapor saturation enthalpy at } T_{0} \text {. }
$$




$$
\mathrm{h}_{\text {gin }}=\text { water vapor saturation enthalpy at } \mathrm{T}_{\mathrm{I}} \text {. }
$$

Heat of vaporization due to evaporation:

$$
q_{E}=m_{E} h_{f g}
$$

where:

$$
h_{f g}=\text { latent heat of vaporization for water at } T_{0} \text {. }
$$

Since the inlet temperature, inlet relative humidity and outlet relative humidity are specified and given the inlet volumetric flow and dome temperature, the above set of equations can be solved to obtain a set of curves that give the evaporation rate versus tank inlet ventilation flow for each outlet temperature or a set of curves that give the heat removal rate versus tank inlet ventilation flow for

each outlet temperature. These curves are shown in the following two figures. 


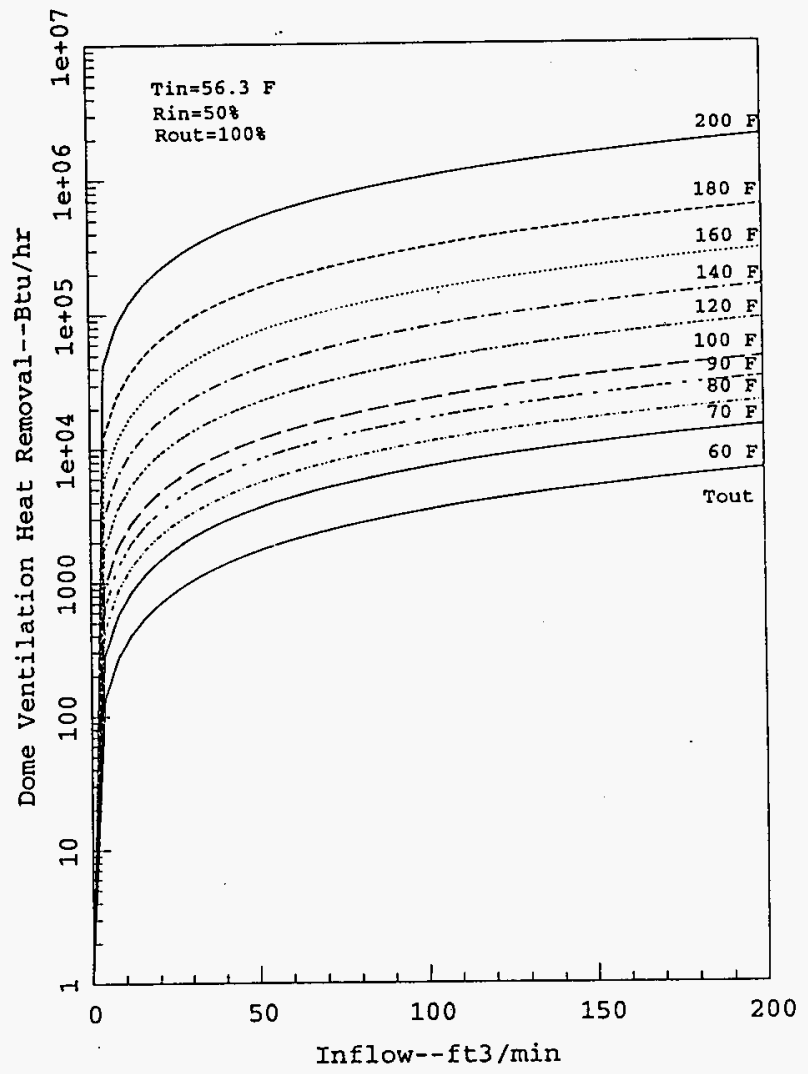

Figure 2.1 Low Heat Tanks with Natural Inflow Leakage. Dome Ventilation Heat Removal versus Inflow and outlet Temperature. 


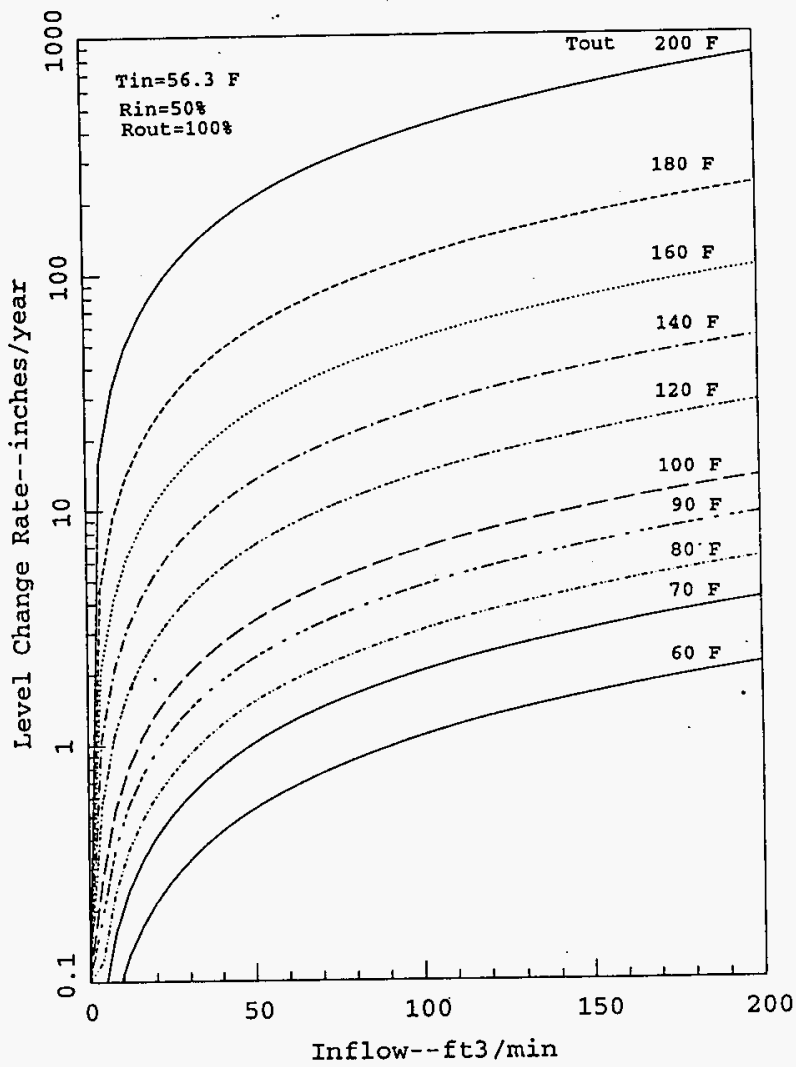

Figure 2.2 Low Heat Tanks with Natural Inflow Leakage. Tank Level Change Due to Evaporation Versus Inflow and outlet Temperature 
If the inlet ventilation flow is known, Figure 2.2 may be used to obtain the level change due to evaporation in inches per year. If the ventilation flow is not known by any of the other two methods for estimating the ventilation flow, then Figure 2.1 may be used to obtain the ventilation flow by assuming the $y$ axis of the graph is the total tank heat load, drawing a horizontal line over to the curve corresponding to the tank dome temperature and then drawing a vertical line down to the horizontal axis of the graph to obtain an estimate for the tank's passive ventilation flow. Using this value for flow, enter Figure 2.1 using the estimate for flow on the horizontal axis and drawing a vertical line to the curve corresponding to the tank's dome temperature. Next draw a horizontal line to the vertical axis to obtain an estimate of the tank evaporation rate in inches/year.

\section{ESTIMATE OF TANK LEVEL CHANGE.}

The change in tank level is estimated in one of two ways.

1. When the tank exhibits a gradual change in level over several years and there is no apparent addition of water or waste nor is there any apparent extraction of waste from the tank, then the tank level early in its history is subtracted from the current tank level to obtain the net change in liquid level over that period of time.

2. When a tank's level is periodically changing (apparently due to water additions, waste subtractions or GRE's) then the most recent occurrence of a steady change in liquid level is used to obtain a rate of level change in inches per year. This rate is then multiplied by the period of time the tank is believe to have been accumulating gas to obtain an estimate of the total change of tank waste level over that period of time. 


\section{ESTIMATE OF TRAPPED GAS VOLUME.}

The estimates for the evaporation rate and the tank level change are used to obtain an estimate for the in situ trapped gas volume. The time from when the tank is estimated to have started accumulating gas until the present time is used to calculate the total evaporation that should have occurred during this time period. If no estimate for the time period when gas generation started to occur is available, the earliest time available on the liquid level plots provided in [Ref 3] is used as the starting point for the trapping of gas. It is recognized that some gas may have been trapped in the waste prior to this time and further refinement of the gas estimate could be made if the time of the start of gas accumulation were more accurately known.

Once the total evaporation is known in inches and the total change in level is known, then the volume of trapped gas can be calculated as the difference between the two. If the measured tank level has increased in time, then the volume of trapped gas is equal to the measured change in level plus the change in level that should have occurred due to evaporation multiplied by the tank cross-sectional area. If the tank level has decreased over time, then the total volume of trapped gas is equal to the difference between the measured change in tank level and the change in tank level that should have occurred due to evaporation.

No limit is placed on the gas volume fraction that can be achieved in the waste.

\section{VOLUME OF H2 RELEASED AND \%LFI IN HEAD SPACE.}

The methods and assumptions for calculating the volume of gas released to the tank head space and for calculating the offL are exactly the same as those given in [Ref 1]. 


\section{RESULTS.}

The estimated ventilation flows, calculated amount of evaporation, estimated change in tank level, tank heat loads used to estimate ventilation flows, tank dome volumes, estimated $\mathrm{H}_{2}$ generation rates and $8 \mathrm{LFL}$ 's resulting from gas generation rates with estimated vent flows and change in level with evaporation are presented in the following table. The of LL calculated assuming the spreadsheet values of $[\operatorname{Ref} 1]$ for the gas generation rate and the estimated ventilation flows obtained from the analysis reported here result in 8LFL's that are very low. This is to be anticipated since small ventilation flows can easily vent all of the gas that is being generated in the passively ventilated tanks and forced ventilation flow can easily remove the gas being generated in actively ventilated tanks without building up high $\mathrm{H}_{2}$ concentrations. The estimated values are also consistent with values that have been measured in the tanks. Flows estimated from the tank heat load are conservative with respect to calculating the evaporation rate and volume of stored gas since they over estimate the evaporation rate. However, they are non conservative for estimating tank flammable gas venting rates since actual passive ventilation flows are likely to be lower than these estimated values.

A conservative estimate of the 8LFL in the dome space can be obtained if the tank barometric breathing rate is used with the estimated gas generation rates.

The SLFL based on tank level change are the values obtained using the methodology described in this letter. The ofLFL has been divided by a factor of 2 when the tank heat load estimate is the only method for estimating the tank ventilation Elow. This is because, for passively ventilated tanks, previous heat transfer analyses have shown that most of the tank heat load can be removed by 
conduction through the ground. The idea behind dividing by 2 is that at least one half of the tank heat load can be expected to be removed by conduction through the soil to the surface, however, dividing the fLFL by this factor is not strictly correct since the gas volume is also affected. by the change in liquid level. The limited time available to perform this analysis has not permitted us to repeat the calculations using one half of the tank heat load (assume $1 / 2$ is lost through the soil). This should be done, time permitting, in the near future. The values given in the table are still considered to be conservative and I would not expect any changes in recommendations for the tank watch list after the calculations are repeated. 
$-$

\begin{tabular}{|c|c|c|c|c|c|c|c|c|c|}
\hline $\begin{array}{c}\text { Tank } \\
\text { Number }\end{array}$ & $\begin{array}{c}\text { Tank Heat Load } \\
(\mathrm{kW})\end{array}$ & $\begin{array}{l}\text { Measure } \\
\text { Hydrogen } \\
\text { Volume } \\
\text { Fraction }\end{array}$ & $\begin{array}{c}\text { Tank } \\
\text { Ventilation } \\
\text { Flow. } \\
\text { (cfm) }\end{array}$ & $\begin{array}{l}\text { Measured } \\
\text { Level Change } \\
\text { (in.) }\end{array}$ & $\begin{array}{c}\text { Tank } \\
\text { Evaporation } \\
\text { (in.) }\end{array}$ & $\begin{array}{c}\text { Tank Dome } \\
\text { Volume } \\
\left(\mathrm{ft}^{3}\right)\end{array}$ & $\begin{array}{c}\mathrm{H}_{2} \text { Gen } \\
\text { Rate } \\
\left(\mathrm{ft}^{3} / \text { day }\right)\end{array}$ & $\begin{array}{c}\text { Steady State } \\
\text { (B.E. flow) } \\
(\%)\end{array}$ & $\begin{array}{l}\text { Tank Level } \\
\text { Method } \\
\text { with Evap } \\
\text { (\% LFL) }\end{array}$ \\
\hline $\mathrm{A} 103$ & 3.4 & & 78 & 0.0 & 42 & 118272 & 6.38 & $0.6 \%$ & $57 \%$ \\
\hline AP105 & & & 150 & -5 & 37.2 & 167135 & 0.49 & $0.012 \%$ & $54 \%$ \\
\hline AP107 & & & 150 & -13.6 & 24 & 184808 & 16.6 & $0.40 \%$ & $14 \%$ \\
\hline AW103 & & & 100 & -7.42 & 18.2 & 119511 & 0.075 & $0.027 \%$ & $33 \%$ \\
\hline AW104 & 3.11 & & 160 & -2.09 & 13.3 & 38233 & 2.68 & $0.10 \%$ & $142 \%$ \\
\hline AW106 & 2.79 & & 48 & -25.2 & 32.84 & 116258 & 3.38 & $0.11 \%$ & $24 \%$ \\
\hline AY101 & & & 600 & -92.12 & 101.5 & 62121 & 24.6 & $0.10 \%$ & $105 \%$ \\
\hline $\mathrm{AZ101}$ & & & 600 & -1291 & 1320 & 67407 & 36.8 & $0.19 \%$ & Bad data \\
\hline BX104 & & $9.4 e^{-5}$ & 8.7 & 0.5 & 5.6 & 101022 & 1.18 & $0.39 \%-0.49 \%$ & $17 \%-31 \%$ \\
\hline $\mathrm{BX} 107$ & 1.35 & & 78 & 0.0 & 16.8 & 68256 & 1.5 & $0.078 \%$ & $45 \%$ \\
\hline $\mathrm{BX} 112$ & 0.926 & & 61 & -1.0 & 12.7 & 92812 & 1.26 & $0.15 \%$ & $19 \%$ \\
\hline BY101 & & & & No Corr & No Corr & 111778 & 1.41 & & Bad data \\
\hline BY 102 & 1.62 & & 73 & 2.0 & 23.8 & 103570 & 2.21 & $0.21 \%$ & $35 \%$ \\
\hline BY103 & & $9.9 e^{-5}$ & 23.5 & 0.0 & 8.4 & 89320 & 3.35 & $0.42 \%-0.52 \%$ & $33 \%-41 \%$ \\
\hline BY105 & & $4.79 e^{-5}$ & 43 & 7.0 & 13.1 & 82095 & 2.97 & $0.25 \%-0.32 \%$ & $56 \%-85 \%$ \\
\hline BY106 & 2.959 & $4.55 \mathrm{e}^{-5}$ & 82 & 6.0 & 40.6 & 50586 & 7.29 & $0.32 \%-0.48 \%$ & $141 \%-365 \%$ \\
\hline BY109 & 0.30 & & 8 & 0.0 & 4.2 & 96959 & 4.7 & $4.2 \%$ & $7.3 \%$ \\
\hline $\mathrm{C} 104$ & & $6.8 \mathrm{e}^{-5}$ & 77.84 & -26 & 44.8 & 81068 & 3.49 & $0.45 \%$ & $66 \%$ \\
\hline $\mathrm{C} 105$ & & $2.2 e^{-5}$ & 110 & -37 & 46.2 & 96353 & 3.5 & $0.12 \%$ & $26 \%$ \\
\hline $\mathrm{C} 107$ & & $2.3 \mathrm{e}^{-1}$ & 1.75 & 0.0 & 2.46 & 81068 & 0.81 & $1.6 \%$ & $7.7 \%$ \\
\hline$\$ 101$ & 1.94 & & 33 & -14 & 28 & 84063 & 3.92 & $0.86 \%$ & $28 \%$ \\
\hline
\end{tabular}




\begin{tabular}{|c|c|c|c|c|c|c|c|c|c|c|}
\hline ' & $\begin{array}{c}\text { Tank } \\
\text { Number }\end{array}$ & $\begin{array}{c}\text { Tank Heat Load } \\
(\mathrm{kW})\end{array}$ & $\begin{array}{c}\text { Measure } \\
\text { Hydrogen } \\
\text { Volume } \\
\text { Fraction }\end{array}$ & $\begin{array}{c}\text { Tank } \\
\text { Ventilation } \\
\text { Flow } \\
(\mathrm{cfm})\end{array}$ & $\begin{array}{c}\text { Measured } \\
\text { Level Change } \\
\text { (in.) }\end{array}$ & $\begin{array}{c}\text { Tank } \\
\text { Evaporation } \\
\text { (in.) }\end{array}$ & $\begin{array}{c}\text { Tank Dome } \\
\begin{array}{c}\text { Volume } \\
\left(\mathrm{ft}^{3}\right)\end{array} \\
\end{array}$ & $\begin{array}{c}\mathrm{H}_{2} \text { Gen } \\
\text { Rate } \\
\left(\mathrm{ft}^{3} / \text { day }\right)\end{array}$ & $\begin{array}{c}\text { Steady State } \\
\text { (B.E. flow) } \\
(\%)\end{array}$ & $\begin{array}{l}\text { Tank Level } \\
\text { Method } \\
\text { with Evap } \\
\text { (\% LFL) }\end{array}$ \\
\hline \multirow{10}{*}{$\begin{array}{r}\pi \\
\frac{1}{\infty}\end{array}$} & $\$ 102$ & & $6.69 \mathrm{e}^{-4}$ & 15.76 & 8.3 & 17.5 & 67949 & 18.4 & $4.2 \%$ & $145 \%-$ \\
\hline & $\$ 103$ & 0.80 & & 27 & 5.54 & 11.2 & 104565 & 1.75 & $0.24 \%$ & $52 \%$ \\
\hline & S105 & & & 400 & No Corr. & No Corr. & 85178 & 0.5 & $.004 \%$ & Bad data \\
\hline & $\$ 106$ & 0.81 & & 43 & 17 & 15.4 & 77587 & 2.85 & $0.48 \%$ & $74 \%$ \\
\hline & $\$ 107$ & 1.08 & & 27 & 9 & 15.4 & 89817 & 2.29 & $0.61 \%$ & $86 \%$ \\
\hline & $\$ 109$ & & & & No Corr. & No Corr. & 79656 & 1.78 & & Bad data \\
\hline & T107 & & $9.4 e^{-5}$ & 6.5 & 1.0 & 1.5 & 90161 & 0.88 & $0.063 \%-0.49 \%$ & $8.6 \%-18 \%$ \\
\hline & T111 & & & 21 & 1.3 & 3.92 & 52904 & 0.83 & $0.14 \%$ & $13 \%$ \\
\hline & TX102 & & & & No Corr. & No Corr. & 113342 & 0.83 & & Bad data \\
\hline & TX107 & & & & & & 136794 & 0.59 & & \\
\hline \multirow{8}{*}{ 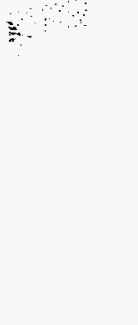 } & $\mathrm{T} \times 111$ & & & & No Corr. & No Corr. & 93646 & 1.52 & & Bad data \\
\hline & TX112 & & & & No Corr. & No Corr. & 56278 & 2.07 & & Bad data \\
\hline & TX113 & & & & No Corr. & No Corr. & $64 \overline{046}$ & 0.67 & & Bad data \\
\hline & $\mathrm{TX} 115$ & & & & No Corr. & No Corr. & 70084 & $0 . \overline{72}$ & & Bad data \\
\hline & TY102 & 0.8 & & 70 & 1.6 & 9.02 & 131640 & 0.85 & $0.084 \%$ & $11 \%$ \\
\hline & TY103 & & $9.3 e^{-3}$ & 8.5 & -2 & 2.4 & 119159 & 1.14 & $0.11 \%-0.48 \%$ & $1.11 \%-0.48 \%$ \\
\hline & $\mathrm{U} 102$ & 1.67 & & 49 & 3.15 & 26.6 & 64317 & 13.8 & $2.0 \%$ & $76 \%$ \\
\hline & U106 & & & 4.8 & 1.0 & 2.24 & 84087 & 1.45 & $0.22 \%-1.0 \%$ & $12 \%-38 \%$ \\
\hline
\end{tabular}




\section{REFERENCES}

1. J.D. Hopkins, "Methodology for Flammabie Gas Evaluations", WHC-SD-WM-TI-724, Rev.0, Westinghouse Hanford Company, November 1995.

2. R.D. Crowe, et. al., "Estimation of Heat Load in waste Tanks Using Average Vapor Space Temperatures.", WHC-EP-0709, Westinghouse Hanford Company, December, 1993.

3. Paul Whitney, "Screening the Hanford Tanks for Trapped Gas", PNL-10821, Battelle Pacific Northwest Laboratories, October, 1995 . 
WHC-SD-WM-TI-724, Rev. 1

Attachment K

This page intentionally left blank 


\section{ATTACHMENT L}

\section{PRESSURE VARIATIONS}


This page intentionally left blank 


\begin{aligned} cc: Mail for: James D (Dave) Hopkins \\ \hline Subject: \\ From: Pressure Variation in Tank Farms \\ To: \\ \hline\end{aligned}

Dave,

I've answered your questions below using information we have here at HMS (Hanford Meteorological Station).

Ken,

I'm analyzing the correlation between surface level changes in tank waste and inverse barometric pressure. For the analysis to be valid, the ground-level pressure at the tanks must closely track the barometric pressure recorded by the PNNL Weather Station. I have 2 questions:

1. What are the average and bounding time intervals (to the closest $5 \mathrm{~min}$.) between the recording of a pressure peak at the Station and the arrival of the peak at the tank farthest from the Station?

A typical weather front will pass through the area at about 25-30 miles per hour. I estimate that the straight line distance from HMS to the east edge of the 200 East area is about 5 miles. So the 200 East area would expect to experience a front anywhere from 10-12 minutes after HMS.

2. Using Station Pressure as a reference, what is the pressure differential per fool of elevation differential.

The "standard" is 1.00 inches $\mathrm{Hg}$ per 1000 feet, or $0.01 \mathrm{in.} \mathrm{Hg}$ per 10 feet.

3. What is the elevation of the Station barometer?

Our station (HMS) is at $733 \mathrm{feet}$, and the 200 East telemetry station is at 680 feet.

4. What is the steepest rate of pressure change seen in our area?

Last December (1995) we had 2 classic severe pressure change incidents.

Dec. 3, 1995: from 1200 PST to 2400 PST the pressure dropped 0.56 inches $(-0.047$ inches/hour), followed by a rise from 2400 PST to 1200 PST $12 / 4 / 95$ of 0.76 inches $(+0.063$ inches/hour)

Dec. 12, 1995: from 000 PST to 1400 PST the pressure dropped 0.58 inches $(-0.041$ inches/hour), followed by a rise from 1400 PST to 0400 PST $12 / 13 / 95$ of 0.61 inches $(+0.044$ inches/hour)

We also have a case documented from 1958.

Nov. 3, 1958: from 1500 to 1600 the pressure dropped 0.16 inches, and from 1500 to 2100 a total of 0.492 inches $(-.082$ inches $/ \mathrm{hr})$, followed by a rise 2300 to 0500

$11 / 4 / 58$ of 0.544 inches $(+0.091$ inches/hour)

\section{Dave - 373-5701}

If you nced any more information please let me know.

$+++++++++++++++++++++++++++++++++++t$

Ken Burk

email: kw_burk@pnl.gov (or ccmail)

(509) $373-\overline{3} 215$

Hanford Meteorological Station (HMS)

Battelle - PNNL S3-91

$++++++++++++++++++++++++++++++++++t$ 


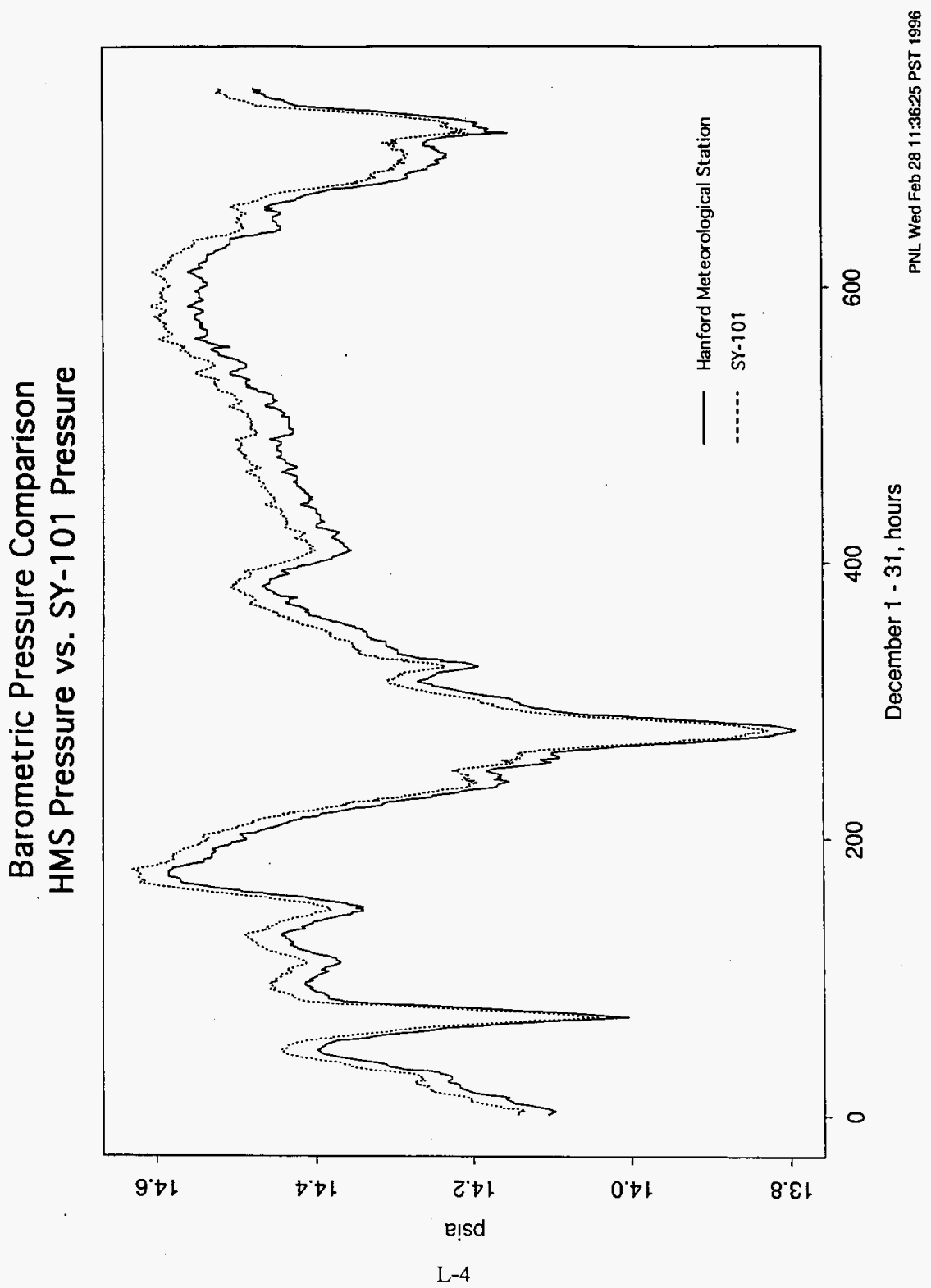




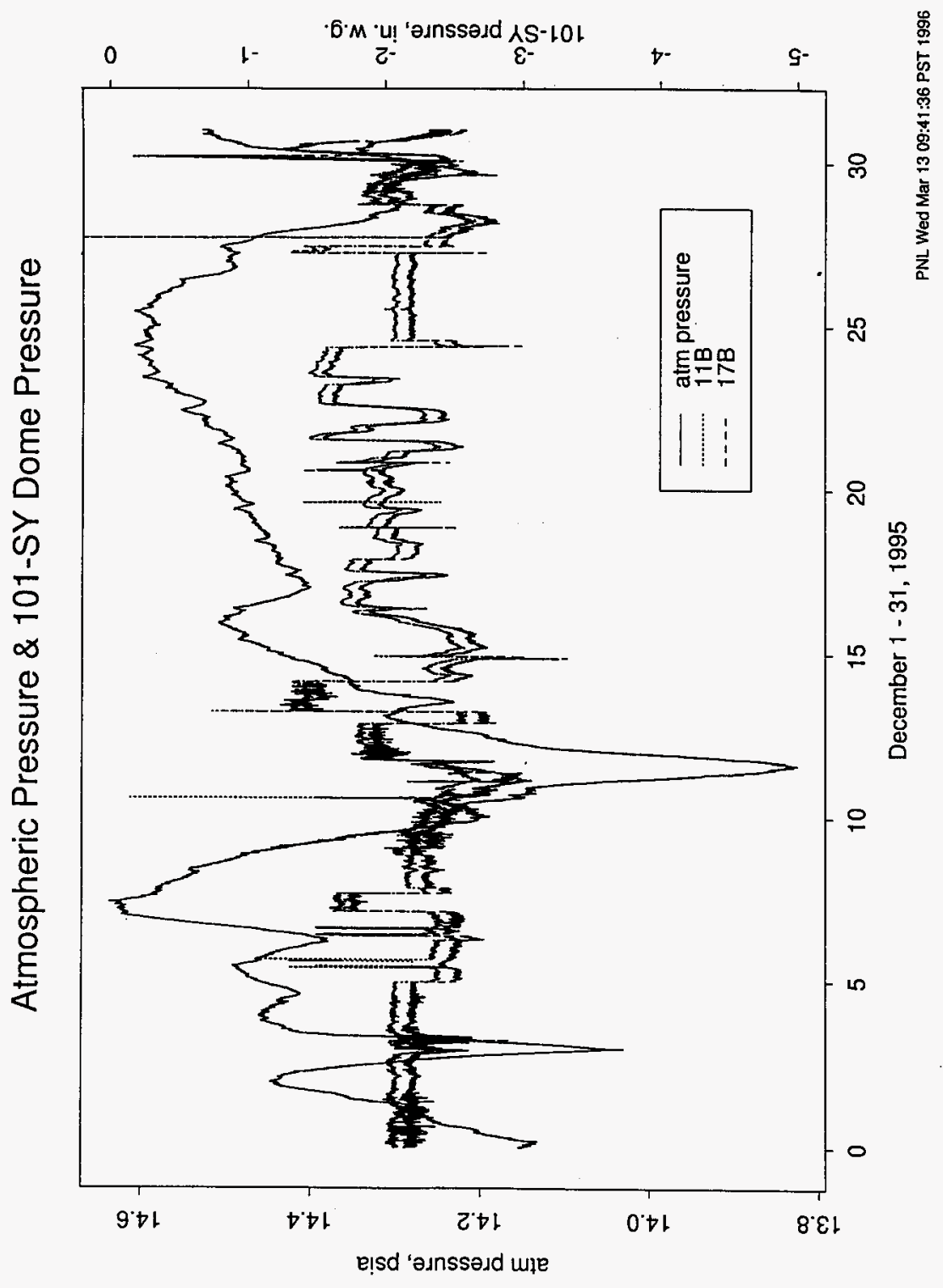




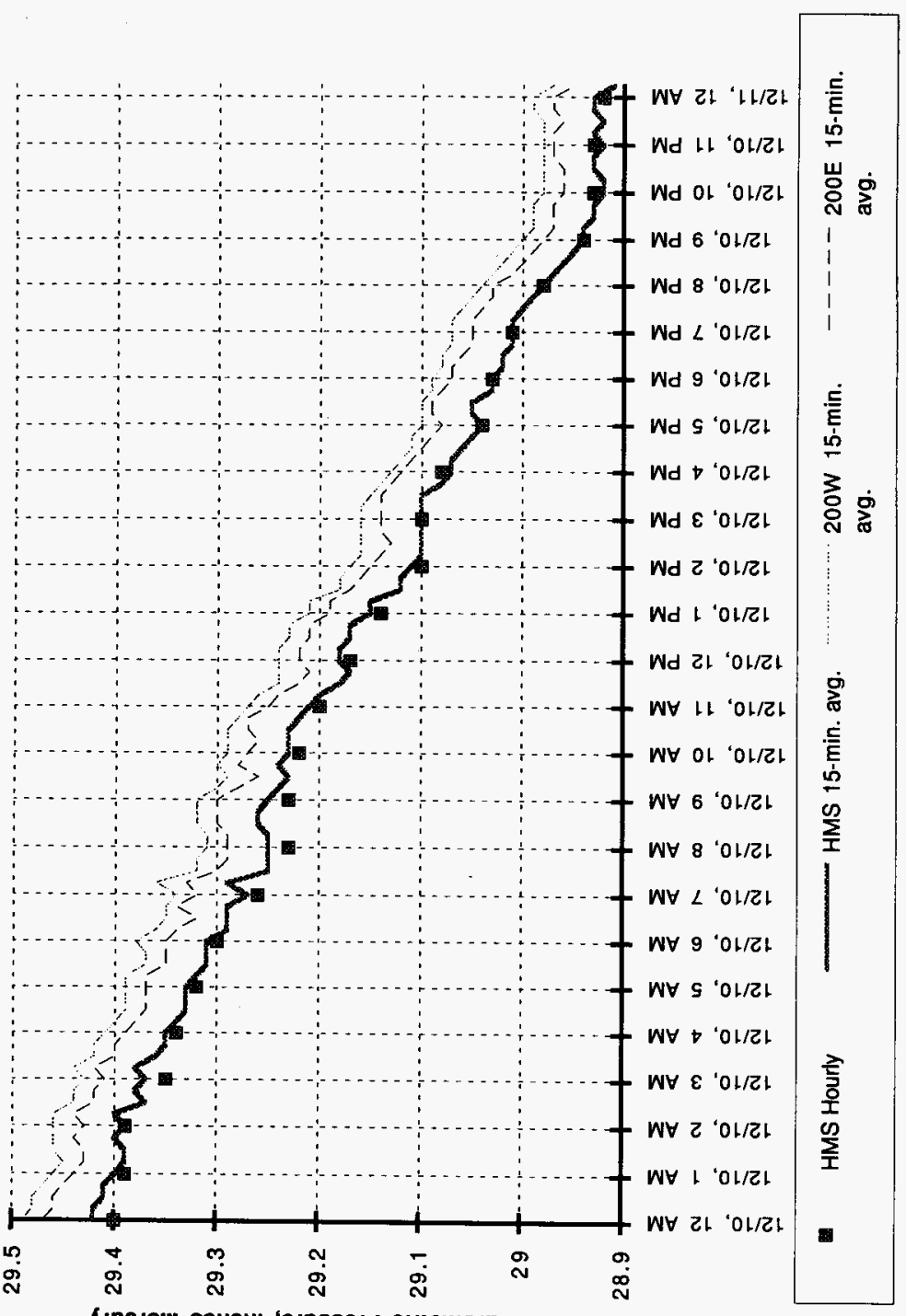

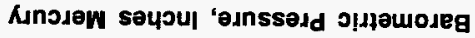




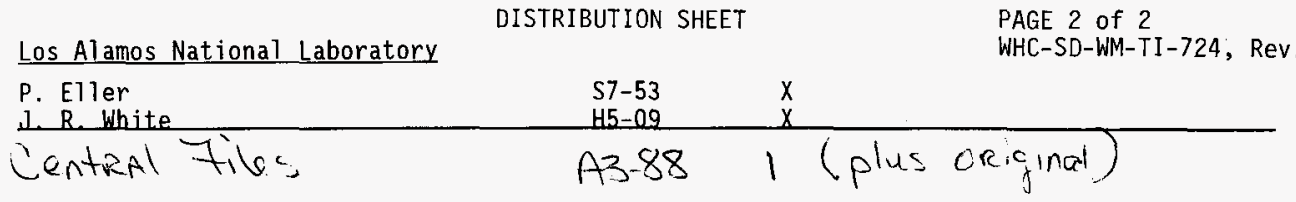

PAGE 2 of 2

Los Alamos National Laboratory

1

A-6000-135 (01/93) WEF067 


\section{DISTRIBUTION SHEET}

\begin{tabular}{|c|c|c|c|c|c|}
\hline To & \multirow{2}{*}{\multicolumn{3}{|c|}{$\begin{array}{l}\text { From } \\
\text { Waste Tank Process Engineering }\end{array}$}} & \multicolumn{2}{|l|}{ Page 1 of 2} \\
\hline Distribution & & & & \multicolumn{2}{|c|}{ DateJune 10,1996} \\
\hline \multicolumn{4}{|l|}{ Project Title/Work Order } & \multicolumn{2}{|c|}{ EDT No.810259 } \\
\hline \multicolumn{4}{|c|}{$\begin{array}{l}\text { Methodology For Flammable Gas Evaluations, WHC-SD-WM-TI-724, } \\
\text { Rev. } 1\end{array}$} & \multicolumn{2}{|c|}{ ECN No.606103 } \\
\hline Name & MSIN & $\begin{array}{c}\text { Text } \\
\text { With All } \\
\text { Attach. }\end{array}$ & Text Only & $\begin{array}{l}\text { Attach./ } \\
\text { Appendix } \\
\text { Only }\end{array}$ & $\begin{array}{l}\text { EDT/ECN } \\
\text { Oniy }\end{array}$ \\
\hline
\end{tabular}

\section{DNSITE}

Department of Energy- Richland Operations
C. P. Bader
C. A. Groendyke
G. W. Rosenwald
D. L. Vieth

\section{Pacific Northwest National Laboratory}

J. W. Brothers

P. A. Gauglitz

P. D. Whitney

Westinghouse Hanford Company

H. Babad

S. A. Barker

W. B. Barton

J. G. Burton

D. B. Engelman

G. R. Franz

G. N. Hanson

K. M. Hodgson

J. 0 . Honeyman

J. D. Hopkins

G. D. Johnson

N. W. Kirch

J. A. Lechelt

T. Morton

R. J. Nicklas

D. M. Ogden

P. E. Peistrup

R. E. Raymond

D. P. Reber

S. H. Rifaey

W. E. Ross

F. A. Schmittroth

J. P. Sloughter

G. A. Stanton Jr.

J. E. Truax

A. M. Umek

J. H. Wicks Jr.

$\begin{array}{ll}\$ 7-51 & X \\ 57-54 & X \\ \$ 7-54 & X \\ 57-54 & X\end{array}$

K5-22 $\quad X$

P7-41 $X$

K5-12 X

$\begin{array}{ll}\text { S7-14 } & X \\ \mathrm{R} 2-11 & X \\ \mathrm{R} 2-11 & X \\ \mathrm{~S} 7-01 & X \\ \mathrm{R} 1-49 & X \\ \mathrm{~A} 2-34 & X \\ \mathrm{~S} 5-05 & X \\ \mathrm{R} 2-11 & X \\ \mathrm{~S} 7-81 & X \\ \mathrm{R} 2-11 & X \\ \mathrm{~S} 7-15 & X \\ \mathrm{R} 2-11 & X \\ \mathrm{R} 2-11 & X \\ \mathrm{~S} 8-05 & X \\ \mathrm{R} 1-43 & X \\ \mathrm{H} 0-34 & X \\ \mathrm{~S} 7-14 & X \\ \mathrm{~S} 7-12 & X \\ \mathrm{~T} 4-08 & X \\ \mathrm{~T} 4-07 & X \\ \mathrm{~S} 5-07 & X \\ \mathrm{H} 0-35 & X \\ \mathrm{R} 2-54 & X \\ \mathrm{~S} 7-21 & X \\ \mathrm{R} 2-50 & X \\ \mathrm{~S} 7-81 & X \\ \mathrm{R} 2-50 & X \\ & \end{array}$

